Prepared in cooperation with California Department of Water Resources

\title{
The Basin Characterization Model—A Regional Water Balance Software Package
}
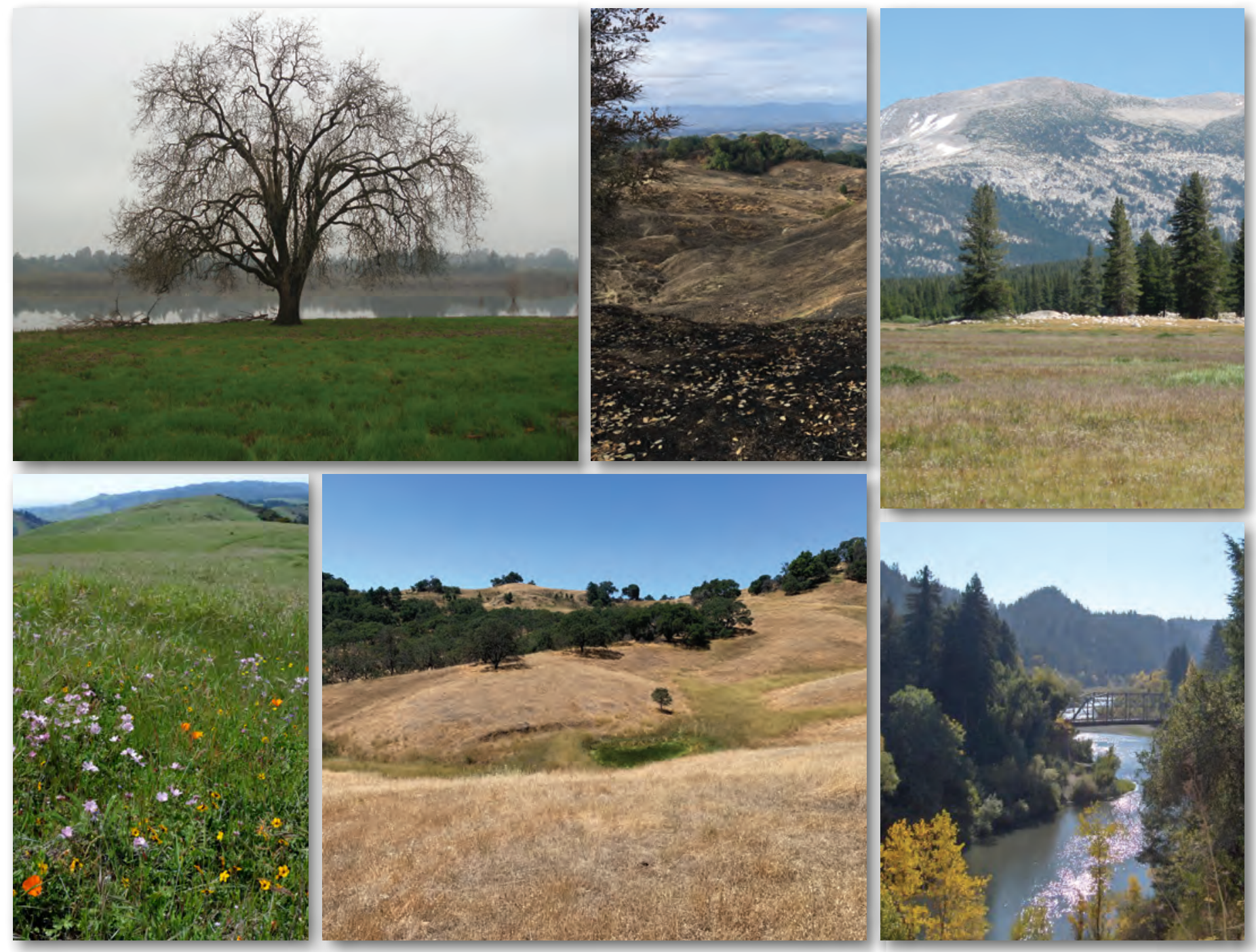

Techniques and Methods 6-H1 


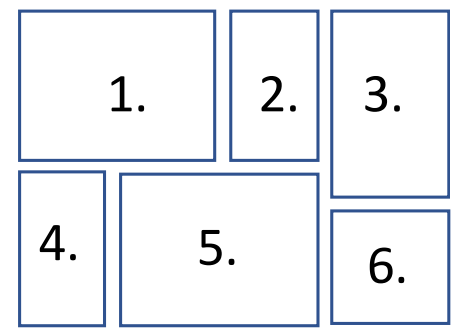

\section{Cover photographs:}

1) Laguna de Santa Rosa, Sebastopol, Calif. Photograph taken by L. Flint, 2004.

2) Wildfire scars, Pepperwood Preserve, Santa Rosa, Calif. Photograph taken by R. Ferrell, 2017.

3) Tuolumne Meadows, Yosemite National Park. Photograph taken by L. Flint, 2006.

4) Butterfly habitat at Russian Ridge Preserve, Redwood City. Photograph taken by S. Weiss, 2014.

5) Redwood Pond, Pepperwood Preserve, Santa Rosa, Calif. Photograph taken by L. Flint, 2019.

6) Russian River, Hacienda, Calif. Photograph taken by A. Flint, 2006.. 


\section{The Basin Characterization Model-A Regional Water Balance Software Package}

By Lorraine E. Flint, Alan L. Flint, and Michelle A. Stern

Prepared in cooperation with California Department of Water Resources

Techniques and Methods 6-H1 


\section{U.S. Geological Survey, Reston, Virginia: 2021}

For more information on the USGS - the Federal source for science about the Earth, its natural and living resources, natural hazards, and the environment—visit https://www.usgs.gov or call 1-888-ASK-USGS.

For an overview of USGS information products, including maps, imagery, and publications, visit https://store.usgs.gov/.

Any use of trade, firm, or product names is for descriptive purposes only and does not imply endorsement by the U.S. Government.

Although this information product, for the most part, is in the public domain, it also may contain copyrighted materials as noted in the text. Permission to reproduce copyrighted items must be secured from the copyright owner.

Suggested citation:

Flint, L.E., Flint, A.L., and Stern, M.A., 2021, The basin characterization model—A regional water balance software package: U.S. Geological Survey Techniques and Methods 6-H1, 85 p., https://doi.org/10.3133/tm6H1.

ISSN 2328-7055 (online) 


\section{Preface}

This report describes the computer software package, Basin Characterization Model, version 8 (BCMv8). This model has been tested and verified in locations throughout California and for several test cases; however, future applications of the software could reveal errors that were not detected in previous analyses. Users are requested to notify the U.S. Geological Survey (USGS) if errors are found in the documentation report or in the computer software.

Correspondence regarding the report or program should be sent to

USGS California Water Science Center

6000 Placer Hall

Sacramento, CA 95819

Attention: Michelle A. Stern

Email: mstern@usgs.gov

This software has been approved for release by the U.S. Geological Survey (USGS). Although the software has been subjected to rigorous review, the USGS reserves the right to update the software as needed pursuant to further analysis and review. No warranty, expressed or implied, is made by the USGS or the U.S. Government as to the functionality of the software and related material nor shall the fact of release constitute any such warranty. Furthermore, the software is released on condition that neither the USGS nor the U.S. Government shall be held liable for any damages resulting from its authorized or unauthorized use. Any use of trade, firm, or product names is for descriptive purposes only and does not imply endorsement by the U.S. Government. 


\section{Acknowledgments}

California's Department of Water Resources, the U.S. Geological Survey California Water Science Center, and the U.S. Geological Survey Cooperative Matching Fund program funded this work, along with BCM development support from several additional Federal, State, and local agencies (Southwest Climate Science Center, California Landscape Conservation Cooperative, Sonoma County Water Agency, National Science Foundation).

We appreciate the comments and input provided by John Engott and Robert S. Regan (U.S. Geological Survey), and testing and feedback from Randall Hanson, Joseph Hevesi, Dina Saleh, Jennifer Curtis, and Alicia Torregrosa (U.S. Geological Survey).

Additional testing and feedback were provided by Danielle Schraitle (University of Illinois) and Andrea Basche (University of Nebraska, Lincoln). We also appreciate the feedback and requests for refinements and innovative applications offered from several individuals that have worked extensively with earlier versions of this model and output: James Thorne and Ryan Boynton (University of California, Davis), Samuel Veloz (Point Blue Conservation Science), Stuart Weiss (Creekside Science for the Environment), Lisa Micheli (Pepperwood Preserve), and Kristin Byrd (U.S. Geological Survey). Additionally, we would like to amplify our appreciation for the cooperation of Meredith Reitz (U.S. Geological Survey) in providing early access to actual evapotranspiration estimates, and without whom our fundamental model refinements and applications would have been less successful. Lastly, we appreciate Debra Curry, Anke Mueller-Solger, and Eric Reichard (U.S. Geological Survey, California Water Science Center) for their support of the BCMv8 and its documentation and for promoting the relevance of the BCM for optimal management of natural resources and groundwater, in particular. 


\section{Contents}

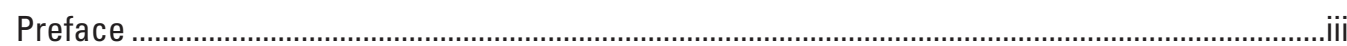

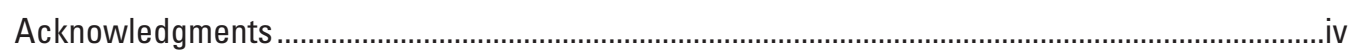

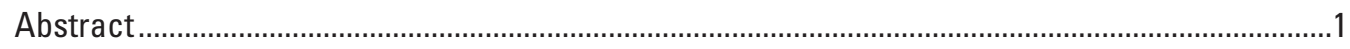

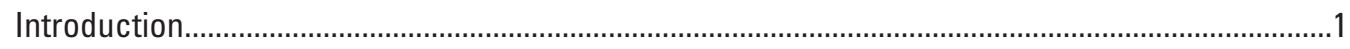

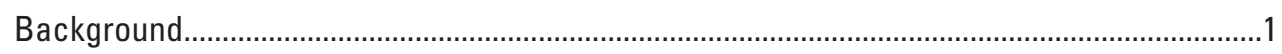

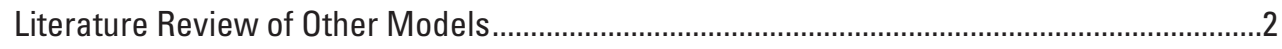

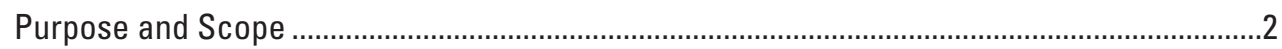

Basin Characterization Model, Version 8 .............................................................................

Description of Computer Software Basin Characterization Model....................................................

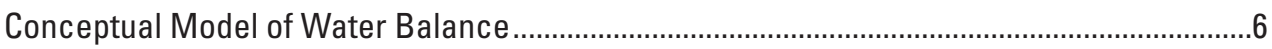

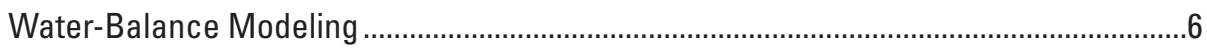

Recharge and Runoff ......................................................................................................

Available Datasets at 270-Meter Spatial Resolution ..................................................................

Developing a BCMv8 Water Balance for a Basin .....................................................................

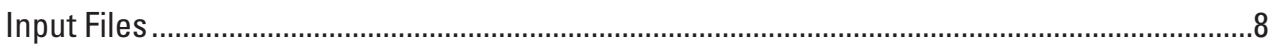

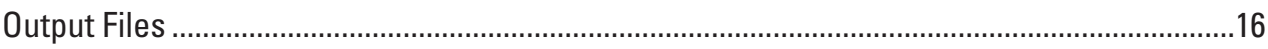

Software Options and the Control File ............................................................................16

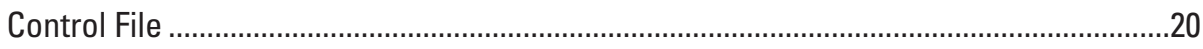

Switch Descriptions and Examples .............................................................................

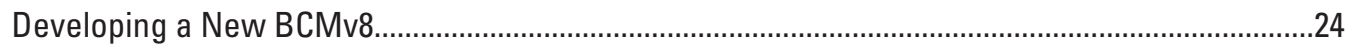

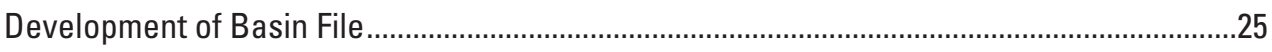

Calibration of Actual Evapotranspiration...........................................................................2.

Calculation of Streamflow to Match Hydrographs (Using CalBasins.xlsx Spreadsheet).......31

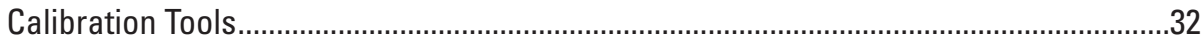

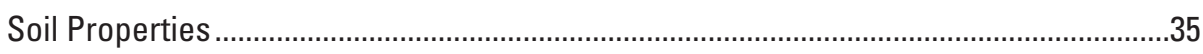

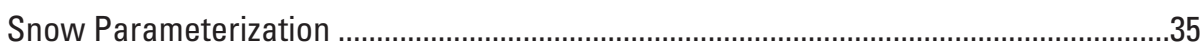

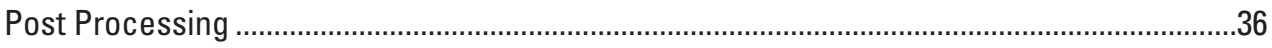

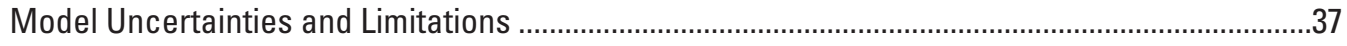

Example Applications ...........................................................................................................

Application 1: Effects of Urbanization on Hydrology ………..............................................38

Application 2: Effects of Wildfire on Hydrology .................................................................

Application 3: Effects of Forest Management on Recharge and Base Flows ........................42

Application 4: Effects of Soil Management on Recharge, Climatic Water Deficit, and Forage Production ......................................................................................................4

Application 5: Applying Future Climate Projections to Evaluate Water Availability................47

Application 6: Implementing Managed Aquifer Recharge .....................................................50

Application 7: Applying BCMv8 Boundary Conditions to Groundwater-Flow Models ............52

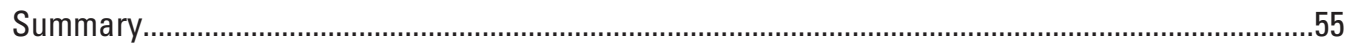

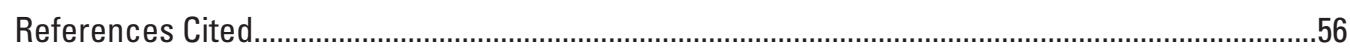

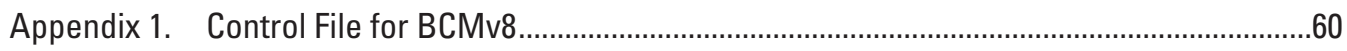

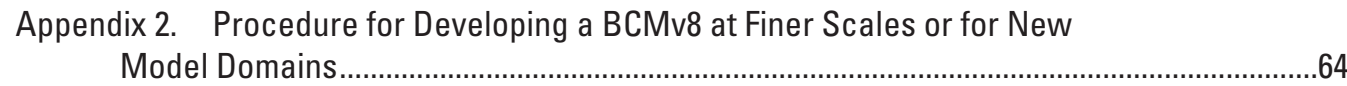

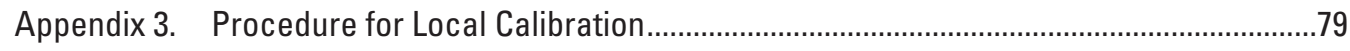

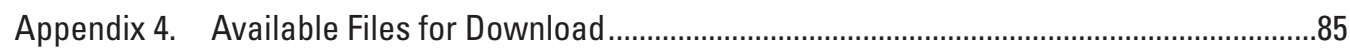




\section{Figures}

1. Map showing existing model output from Basin Characterization Model, version 8, for California illustrating model, county, and basin boundaries and average annual recharge for water years 1981-2010.

2. Schematic describing inputs, outputs, and water-balance components of the Basin Characterization Model, version 8.

3. Line graphs showing relations among potential and actual evapotranspiration and soil-water content calculated by the Basin Characterization Model, version 8 , with vegetation and version 6.5 without vegetation for two vegetation types.

4. Map showing the Merced-Tuolumne model domain including basin boundaries for the Merced River upstream from U.S. Geological Study streamgages 11264500 Merced River at Happy Isles, 11266500 Merced River upstream from Pohono, California Data Exchange Center (CDEC) full natural flows for Exchequer Reservoir, Tuolumne River upstream from streamgage 11276500 near Hetch Hetchy, and CDEC full natural flows for Don Pedro Reservoir..

5. Screenshot showing an example of simulation output file where all input and output variables are calculated monthly.

6. Screenshot of the BCMv8 control file with required and optional entries, not including LOOKUP tables for geology and vegetation.

7. Graphs and map showing simulation results from model runs with the SOLAR switch on and off for the upper Merced River basin for snowmelt for water years (WY) 2012-15, snowpack for WY2012-15, and difference in snow-water equivalent for Apr 1, 2011

8. Line graphs showing effects on simulation results for the Merced-Tuolumne basin, 2008-14, of the Priestley-Taylor switch

9. Graphs showing the effects of using the $\mathrm{RCH} / \mathrm{RUN}$ scaler on recharge and runoff for a range of annual precipitation values for the upper Mad River basin for water years $2009-15$ for two scalers, 0.5 and 0.2 .

10. Line graph showing precipitation and simulated soil-water content that is field verified on the basis of measured soil-water content at a grassland site in northern California.

11. Screenshot showing convention for using INGEST to replace files with 2 months of measured data...

12. Illustration showing the steps to the develop a basin file for five basins above streamgages and two snow sensors, indicated over a shaded relief map of the Merced-Tuolumne basin

13. Line graphs showing monthly actual evapotranspiration from Reitz and others (2017) illustrating varying sensitivity to annual variability in precipitation by different vegetation types

14. Map showing distribution of vegetation types in the Upper Mad River subbasin where Douglas fir is predominant and used to test disturbance effects on actual evapotranspiration.

15. Line graphs showing sensitivity of actual evapotranspiration to the LAI vegetation parameter for two vegetation types 
16. Line graphs showing sensitivity of actual evapotranspiration to the UpRate vegetation parameter following disturbance, where post-event LAI initially equals 0 , in controlling recovery and actual evapotranspiration for average annual precipitation, twice the average annual precipitation, and half the average annual precipitation

17. Line graph showing sensitivity of actual evapotranspiration to the DnRate vegetation parameter for $L A=1$ and 50 percent of average precipitation

18. Schematic describing post-processing of Basin Characterization Model version 8 recharge and runoff map outputs to calculate basin discharge for comparison with streamflow measurements

19. Screenshot of an example calibration spreadsheet..

20. Bar graph showing sensitivity of the recharge to runoff ratio relative to bedrock conductivity for different geologic rock types and climatic conditions ............................34

21. Screenshot showing an example of a control file for AddAveGrids ................................36

22. Screenshot showing an example control file for Linreg .................................................37

23. Maps showing examples of projected urbanization in drainage basin of Alameda Creek, California, showing water years 1981-2010 recharge, runoff, and future projections of increased urbanization.

24. Line graphs showing projected change in runoff and recharge in Alameda Creek Basin, Calif., under a future climate scenario without urbanization projections and with increased urbanization projections applied decadally

25. Maps showing simulation of the effects of the August 2013 Rim Fire with adjustments to vegetation density according to burn-severity index for vegetation types in calibration basin

26. Graph showing simulation of the effects of the August 2013 Rim Fire changing leaf area index (LAI) on post-fire streamflow in the Tuolumne River downstream from Hetch Hetchy Reservoir, California

27. Graphs showing effects of forest die-off on recharge and runoff in the Merced River basin, California

28. Graphs showing effects of forest management on base flows in the Mad River basin, California, indicating that decreases in LAl, correspond to increases in late-summer basin discharge.

29. Graph showing soil water-holding capacity for different soil textural classes by different percentages of soil organic matter

30. Maps showing changes as a result of increasing soil organic matter by 3 percent for 1981-2010 in all soils collocated with vegetation types classified as annual grasslands, croplands, or shrublands to modeled recharge in Tehama County, climatic water deficit in Santa Barbara County, and actual evapotranspiration in Tulare County

31. Graph showing annual recharge and runoff calculated using the BCMv8 for the Russian River basin for 1920-2017 and for a future climate scenario representing a warmer climate with moderately increased rainfall

32. Maps showing average annual recharge for subbasins in the upper Russian River basin, Mendocino County, California, under climates projected by the BCMv8. 
33. Maps of California rice-field example showing annual recharge for water year 2010 representing simulations of natural conditions with no managed flooding, traditionally managed seasonal flooding for rice, and extended managed-recharge scenario with traditional flooding plus additional flooding in August and September

34. Graph showing monthly time series of recharge for rice field under natural conditions with no managed flooding, managed seasonal flooding of rice, and additional flooding in August and September, water year 2010, California

35. Maps showing example application of BCMv8 to groundwater-flow model for the Cuyama Valley, California

36. Maps showing basins developed for time-series inputs to groundwater-flow model for recharge and runoff.

\section{Tables}

1. Future climate scenarios available for representative concentration pathways 4.5 and 8.5 for California using the Basin Characterization Model version 8

2. List of files for static-property inputs required to run the Basin Characterization Model version 8.

3. List of files for gridded time-series inputs required to run the Basin Characterization Model version 8

4. List of files for average monthly climate inputs required to run the Basin Characterization Model version 8

5. LOOKUP table 1 (in control file) list of geology types with identifiers and default bedrock conductivity values.

6. LOOKUP table 2 (in control file) list of vegetation types, density and growth parameters, and $\mathrm{K}_{\mathrm{v}}$ values to calculate actual evapotranspiration for the California statewide calibration

7. Input climate and output hydrologic variables for the BCMv8 with codes used in filenames, and description of calculations

8. Suggested value ranges for vegetation parameters for calibration or recovery exercises

9. Sensitivity of recharge/runoff ratio to a range of bedrock conductivities in millimeters per day for two geologic rock types and a range of basin precipitation values.

10. Change in frequency of rainfall extremes per decade from the historical period in comparison to six climate change projections

11. Recharge estimates for water years 1981-2010 and BCMv8-projected future changes in recharge for 2070-99 under three future climate scenarios in two groundwater subbasins in the upper Russian River basin, Mendocino County, California 


\section{Conversion Factors}

International System of Units to U.S. customary units

\begin{tabular}{|c|c|c|}
\hline Multiply & By & To obtain \\
\hline \multicolumn{3}{|c|}{ Length } \\
\hline centimeter $(\mathrm{cm})$ & 0.3937 & inch (in.) \\
\hline millimeter (mm) & 0.03937 & inch (in.) \\
\hline meter $(\mathrm{m})$ & 3.281 & foot $(\mathrm{ft})$ \\
\hline \multicolumn{3}{|c|}{ Area } \\
\hline square meter $\left(\mathrm{m}^{2}\right)$ & 0.0002471 & acre \\
\hline square meter $\left(\mathrm{m}^{2}\right)$ & 10.76 & square foot $\left(\mathrm{ft}^{2}\right)$ \\
\hline square centimeter $\left(\mathrm{cm}^{2}\right)$ & 0.1550 & square inch $\left(\mathrm{ft}^{2}\right)$ \\
\hline square kilometer $\left(\mathrm{km}^{2}\right)$ & 0.00000010764 & square foot $\left(\mathrm{ft}^{2}\right)$ \\
\hline \multicolumn{3}{|c|}{ Volume } \\
\hline cubic meter $\left(\mathrm{m}^{3}\right)$ & 35.31 & cubic foot $\left(\mathrm{ft}^{3}\right)$ \\
\hline cubic meter $\left(\mathrm{m}^{3}\right)$ & 0.0008107 & acre-foot (acre-ft) \\
\hline \multicolumn{3}{|c|}{ Flow rate } \\
\hline cubic meter per second $\left(\mathrm{m}^{3} / \mathrm{s}\right)$ & 70.07 & acre-foot per day (acre-ft/d) \\
\hline meter per second $(\mathrm{m} / \mathrm{s})$ & 3.281 & foot per second (ft/s) \\
\hline cubic meter per second $\left(\mathrm{m}^{3 / s}\right)$ & 35.31 & cubic foot per second $(\mathrm{ft} 3 / \mathrm{s})$ \\
\hline cubic meter per day $\left(\mathrm{m}^{3} / \mathrm{d}\right)$ & 35.31 & cubic foot per day $(\mathrm{ft} 3 / \mathrm{d})$ \\
\hline \multicolumn{3}{|c|}{ Pressure } \\
\hline megapascal (MPa) & 0.00009869 & atmosphere, standard (atm) \\
\hline megapascal (MPa) & 0.0001 & bar \\
\hline megapascal (MPa) & 0.002961 & inch of mercury at $60^{\circ} \mathrm{F}$ (in $\mathrm{Hg}$ ) \\
\hline \multicolumn{3}{|c|}{ Density } \\
\hline gram per cubic centimeter $\left(\mathrm{g} / \mathrm{cm}^{3}\right)$ & 62.4220 & pound per cubic foot $\left(\mathrm{lb} / \mathrm{ft}^{3}\right)$ \\
\hline \multicolumn{3}{|c|}{ Hydraulic conductivity } \\
\hline meter per day $(\mathrm{m} / \mathrm{d})$ & 3.281 & foot per day (ft/d) \\
\hline \multicolumn{3}{|c|}{ Energy } \\
\hline megajoules (MJ) & 0.000001 & watts per second (watts/s) \\
\hline
\end{tabular}

Temperature in degrees Celsius $\left({ }^{\circ} \mathrm{C}\right)$ may be converted to degrees Fahrenheit $\left({ }^{\circ} \mathrm{F}\right)$ as follows:

$$
{ }^{\circ} \mathrm{F}=\left(1.8 \times{ }^{\circ} \mathrm{C}\right)+32 .
$$

Temperature in degrees Fahrenheit $\left({ }^{\circ} \mathrm{F}\right)$ may be converted to degrees Celsius $\left({ }^{\circ} \mathrm{C}\right)$ as follows:

$$
{ }^{\circ} \mathrm{C}=\left({ }^{\circ} \mathrm{F}-32\right) / 1.8 \text {. }
$$

The latent heat of vaporization of water is measured in megajoules per kilogram $(\mathrm{MJ} / \mathrm{kg})$, which can be converted to megacalories per pound by multiplying $\mathrm{MJ} / \mathrm{kg}$ by 0.1083 . Energy units are reported in megajoules per square meter per day $\left(\mathrm{MJ} / \mathrm{m}^{2} / \mathrm{d}\right)$, which can be converted to megacalories per square foot per day by multiplying $\mathrm{MJ} / \mathrm{m}^{2} / \mathrm{d}$ by 0.0222 . 


\section{Datum}

Vertical coordinate information is referenced to the North American Vertical Datum of 1988 (NAVD 88).

Horizontal coordinate information is referenced to the North American Datum of 1983 (NAD 83).

Elevation, as used in this report, refers to distance above mean sea level.

\section{Abbreviations}

AET Actual evapotranspiration calculated by BCMv8

BCM Basin Characterization Model

BCMv65 Basin Characterization Model, version 6.5

BCMv8 Basin Characterization Model, version 8

CA-BCM California Basin Characterization Model, version 6.5, published 2014

CDEC California Data Exchange Center

CIMIS California Irrigation Management Information System

CWD Climatic water deficit

DEM Digital elevation model

DOS Disk operating system

DWR California Department of Water Resources

ET Evapotranspiration

ETa Actual evapotranspiration estimated by Reitz and others (2017)

FRAP Fire Resource and Assessment Program

GCM Global Climate Model

GEOL Geologic bedrock conductivity switch

GeolK Bedrock conductivity parameter values

Ksat Soil saturated hydraulic conductivity

LAI Relative leaf area index used for changing density for disturbance analysis

LOCA LoCalized Constructed Analogues statistical downscaling method

MSE Mean squared error

NAD83 North American Datum defined in 1983

NHD National Hydrography Dataset

NLCD National Land Cover Dataset

NRCS Natural Resource Conservation Service

NREL National Solar Radiation dataset

NSE Nash-Sutcliffe Efficiency statistic 


\author{
PET Potential evapotranspiration \\ PPT Precipitation \\ PRISM Parameter-elevation Relationships on Independent Slopes Model \\ PT Priestley-Taylor switch \\ $\mathrm{R}^{2} \quad$ Coefficient of determination statistic \\ $\mathrm{RCH}$ Recharge \\ RUN Runoff \\ RCH/RUN Recharge-runoff scaler switch \\ RCP Representative concentration pathway \\ SFR MODFLOW groundwater modeling streamflow-routing package \\ SOM Soil organic matter \\ SSURG0 Natural Resource Conservation Service soil survey geographic database \\ STR Soil-water storage \\ SWE Snow-water equivalent \\ TMN Minimum air temperature \\ TMX Maximum air temperature \\ USGS U.S. Geological Survey \\ WHC Soil water holding capacity \\ WY Water year, October through September, designated by the year in which it ends
}





\title{
The Basin Characterization Model_A Regional Water Balance Software Package
}

\author{
By Lorraine E. Flint, Alan L. Flint, and Michelle A. Stern
}

\section{Abstract}

This report documents the computer software package, Basin Characterization Model, version 8 (BCMv8) - a monthly, gridded, regional water-balance model — and provides detailed operational instructions and example applications. After several years of many applications and uses of a previous version, CA-BCM, published in 2014, the BCMv8 was refined to improve the accuracy of the water-balance components, particularly the recharge estimate, which is the most difficult to accurately assess. The improvement of the various water-balance components targeted the actual evapotranspiration component, which, in turn, reduced the uncertainty of the recharge estimate. The improvement of this component was enabled by the availability of a national, gridded actual-evapotranspiration product from the U.S. Geological Survey that was unique in its scope to combine remotely sensed spatial variability and ground-based long-term water-balance constraints. This dataset provided the ability to assess monthly actual evapotranspiration for 62 vegetation types and to perform regional calibration in watersheds throughout California with the objective of closing the water balance using improved estimates for each component. The refinements, including vegetation-specific evapotranspiration, enabled the development of applications that could explore various aspects of landscape disturbance, such as wildfire, forest management, or urbanization. The improvements to BCMv8 also provided the ability to assess long-term sustainability of water resources under a variety of management applications or future climate projections.

\section{Introduction}

The Basin Characterization Model is a regional water-balance model that has been used to characterize the hydrologic response to changes in climate at a fine scale, providing a tool for multiple disciplines and applications, from impacts of drought to water-supply for statewide agencies to threats from warming on biodiversity for non-profits and academics.

\section{Background}

The Basin Characterization Model (BCM) was developed for the Desert Southwest to evaluate hydrologic differences among basins (Flint and others, 2004; Flint and Flint, 2007) and highlighted the spatial distribution of recharge in that arid environment. Since then, the BCM has been calibrated to many streamgages throughout the West, as well as several basins worldwide, and has been used extensively to evaluate the hydrologic response to current climate and future climate scenarios. A typical BCM application characterizes water availability as recharge and runoff components of the water balance and considers potential changes due to climate (Flint and others, 2015; Thorne and others, 2015; Flint and Flint, 2012; Hanson and others, 2012). Other applications have evaluated refugia as a climate change adaptation strategy (Morelli and others, 2017; McCullough and others, 2015; Ackerly and others, 2020). These kinds of results, whereby fine-scale refugia (north facing hillslopes, valley bottoms, basins with cold-air pooling, and so on) are identified that resist large changes due to future climates (Curtis and others, 2014), provide tools and resources for managers to plan adaptation strategies for conservation of species, and have advanced the science of applying the consequences of climate change to resource management.

Of particular interest to many ecological investigations, agricultural studies, landscape and wildfire studies, and species distribution modeling efforts is climatic water deficit, a variable that is calculated using the BCM. Climatic water deficit is not a new concept but was developed using the $\mathrm{BCM}$ to more accurately refine the local estimate of the water deficit in the landscape. This application has been sought by numerous researchers for application to understand effects of climate change on vegetation and faunal species (Finn and others, 2010; Conlisk and others, 2012; Chardon and others, 2014; Millar and others, 2015; Maher and others, 2017). 
The fine spatial scale has also been useful for researchers developing conceptual process models using point or plot data for such applications as forest die-off (van Mantgem and others, 2013; Anderegg and others, 2015), Sierra Nevada fens (Drexler and others, 2013), forest structure (McIntyre and others, 2015), and wildfire occurrence and severity (Mann and others, 2016). Climatic water deficit is also indicative of agricultural demand and can be used as an indicator of changes in future water use. This variable has caught the interest of the wine industry for assessing future habitat suitability for grape varietals and is being used in studies assessing potential changes in water availability for water agencies.

\section{Literature Review of Other Models}

Many approaches to hydrologic modeling have been developed. The U.S. Geological Survey (USGS) Precipitation-Runoff Modeling System (PRMS) is used to simulate flows under future climate conditions at the watershed scale (Leavesley and others, 1983; Hay and others, 2011). This approach requires daily temperature and precipitation values that are applied to individual watersheds and used in a deterministic distributed-parameter setting (Risley and others, 2011). The Variable Infiltration Capacity model (VIC) is a spatially explicit physical-hydrology model, generally run regionally at coarse spatial scales, that balances energy and water budgets (Liang and others, 1994) and also runs using daily data (Wood and others, 2002). This model has also been applied to monthly climate in a model comparison study by Maurer and others (2010), who found that model selection was not so important for capturing high-flow timing but for the low flows, the models tested varied, implying a need to vet model performance, particularly for regions undergoing aridification. These rainfall-runoff models are specifically calibrated to discharge data. Other hydrologic modeling approaches have used streamgage data to validate the model projections using current or historical data. Alkama and others (2011) developed the Interactions between Soil, Biosphere, and Atmosphere-Total Runoff Integrating Pathways (ISBA-TRIP) and looked at multi-decadal variability in continental runoff from 1960 to 1994 using 154 large rivers having different lengths of streamgage data for validation. Chiew and others (2010) found that five different downscaling techniques all reproduced observed rainfall, and runoff models used could reproduce observed streamflows for eight basins in Australia. These efforts point to the need to understand the capacity and limitations of hydrologic models that are used for future projections of water-balance conditions.
All these rainfall-runoff models rely on soil storage in some capacity, yet do not incorporate bedrock properties; thus, they neglect the influence of spatially varying bedrock conductivity in estimates of recharge. Experimental evaluations of hillslope processes include a few that have investigated the influence of bedrock conductivity on hydrologic response to climate (Hutchinson and Moore, 2000; Tromp-van Meerveld and others, 2007), and a few others numerically modeled watersheds including bedrock properties (Flint and Flint, 2007; Jones and others, 2006; Hopp and McDonnell, 2009). Generally, these models are two- or three-dimensional finite-element models that explicitly incorporate bedrock but are computationally intensive and cover small areas. Historically, recharge estimates have relied on monthly water-balance models that incorporate simulations of evapotranspiration (Alley, 1984), inverse modeling (Sanford and others, 2001), or lysimetry and tracer tests (Gee and Hillel, 1988). Water-balance modeling to assess both recharge and runoff has been done at the site scale (Flint and others, 2001; Ragab and others, 1997) and integrated with various measurements addressing different spatial scales (Flint and others, 2002). Watershed-scale or regional-scale modeling to estimate recharge and runoff has been done using water-balance modeling by Hevesi and others (2003), Flint and others (2011), and Flint and Flint (2007).

\section{Purpose and Scope}

The objective of this report is to make the $\mathrm{BCM}$, version 8 (BCMv8), widely accessible to those who do not just need data layers but want to manipulate the model to run sensitivity analyses, future climate analyses, or test various kinds of resource-management scenarios, such as forest restoration or urban planning, to evaluate water supply, landscape stress or irrigation demand. Users may want to study specific locations or develop models in locations that have not had prior model development or develop climatic and hydrologic boundary conditions for groundwater-flow models. Additionally, the detailed descriptions provide additional information for those with existing BCMv8 output. This document will provide specific operator instructions for (1) developing a BCMv8 model in a new location or at a different grid-cell resolution, (2) using existing California model files to clip to a smaller basin area and perform a local calibration to refine recharge estimates, and (3) providing case study examples of model use to perform scenario testing. Sensitivity analyses are provided for the adjustable parameters to change physical basin attributes or calibrate the model. 


\section{Basin Characterization Model, Version 8}

The $\mathrm{BCMv} 8$ is a refined version of the Basin Characterization Model (BCMv65, Flint and others, 2013; Flint and Flint, 2014). It has been revised to include seven new features: (1) monthly vegetation-specific actual evapotranspiration (AET) for 65 vegetation types, (2) spatially distributed calibration coefficients for snow accumulation and snowmelt, (3) mapped soil organic matter, (4) soil hydraulic properties calculated from soil texture and soil organic matter (model simulations run using water content at field capacity of -0.01 megapascal (MPa) and wilting point of $-6 \mathrm{MPa}$ ), (5) soil dry-out below wilting point at a rate driven by average statewide aridity, (6) a switch allowing for the incorporation of urban impermeable surfaces, and (7) internally calculated gaining and losing streams. The model has been run at a monthly time scale to calculate the unimpaired water balance for every 18 -acre ( 270 by 270 -meter) grid cell for all of California, including all basins draining into the State (fig. 1) for water years 1896-2019. Average annual recharge for water years 1981-2010 is shown in figure 1.

We have performed rigorous calibrations at a statewide basis to improve the accuracy of all components of the water balance (fig. 2). Precipitation, snow processes, and the energy balance were developed and calibrated statewide. Calibrations have been done to constrain the other variables, including AET as a function of available soil water and vegetation type and recharge versus runoff as a function of soil storage and bedrock conductivity. Calibration exercises have been done using a series of approaches to develop confidence in the regional estimates. Regional calibration results in errors that are minimized statewide, and because they rely on bedrock types and vegetation types that may span very large areas, errors may be positive or negative in different watersheds. Simulated BCMv8 results were compared to base-flow separation analyses at 160 streamgages, to 20 basins for which recharge was estimated as part of groundwater flow modeling, to gridded actual-evapotranspiration estimates for 2000-15 (Reitz and others, 2017) for 62 vegetation types, to estimates of full natural flows provided by the Department of Water Resources (DWR) California Data Exchange Center (CDEC, https://cdec.water.ca.gov/) for basins draining into the Central Valley, and to 65 small gaged basins that have relatively unimpaired streamflow (GAGES II; Falcone, 2011). Because of the regional calibration and associated errors, subregional applications of BCMv8 could benefit from additional local calibration to obtain more accurate estimates for calculating the water balance in a given watershed.

The biggest difference resulting from refinements in calculating the water balance in the BCMv8 is the inclusion of vegetation-specific AET. Previous versions of the BCM (BCMv65) assumed AET to be the same as potential evapotranspiration (PET) rates until soil water content reached the wilting point (fig. 3). The comparison of AET for the different model versions is shown in figures representing a basin with few water-supply limitations (fig. $3 A$ ) and a basin that is water-supply limited (fig. $3 B$ ) by the dotted lines, indicating where the soil water content declines in late summer as a result of AET. The solid lines show the BCMv8 estimates of AET that are monthly proportions of PET $\left(\mathrm{AET} / \mathrm{PET}=\mathrm{K}_{\mathrm{v}}\right)$ based on AET observations. The use of monthly $\mathrm{K}_{\mathrm{v}}$ values results in less AET during cooler winter months and more soil water available for AET in warmer months, thus altering the seasonality of water use. This seasonality is particularly notable for the blue oak woodland, where less AET in the winter allows for higher AET later in the season than the $\mathrm{BCMv} 65$ forecast because there is more available soil water in the former simulation.

Model results are for "unimpaired" streamflows, meaning they represent natural hydrologic conditions, where water is not extracted from nor delivered to a basin. Simulations for locations with mapped irrigated agriculture assume no irrigation; for mapped urban footprints, impermeable surfaces are represented by a bedrock conductivity similar to granite, which increases runoff and decreases recharge relative to permeable surfaces.

Maps generated by the $\mathrm{BCMv} 8$ indicate the quantity of recharge and runoff and where in the watershed they are generated. Recharge may not be generated directly over a groundwater-basin footprint but rather could correlate with mountain-front recharge from surrounding landscapes in a watershed or with mountain-block recharge directly into unsaturated bedrock. Recharge to a groundwater basin may also come from adjacent surface-water basins if the underlying geology is very permeable. Runoff may contribute to recharge in locations that have losing streams and unsaturated zones. Values of recharge and runoff for all grid cells in a watershed can be accumulated to provide a first approximation of available water in a basin, some of which may leave by streamflows. The "unimpaired water supply" of a basin, therefore, can be approximated by recharge plus runoff. 


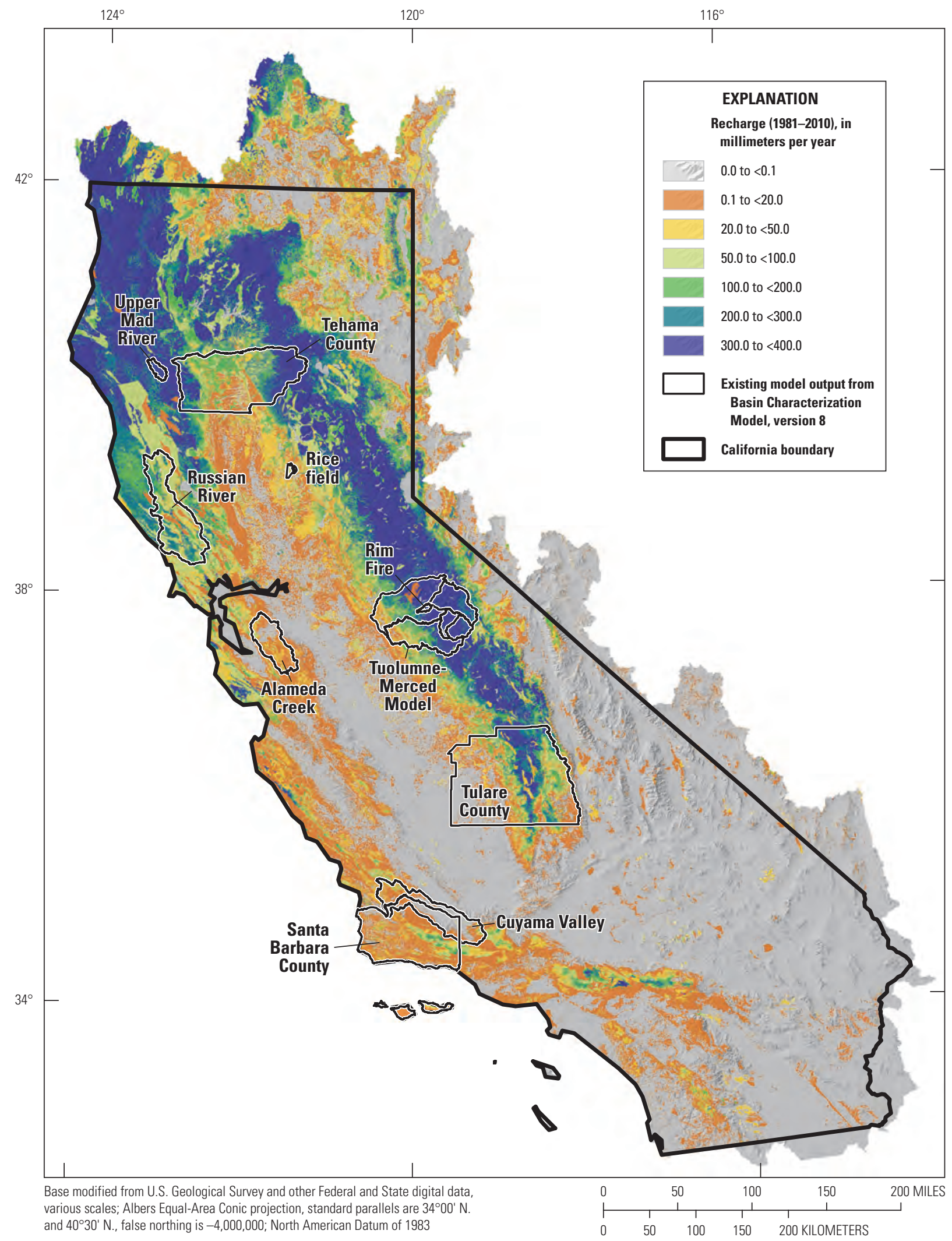

Figure 1. Existing model output from Basin Characterization Model, version 8, for California illustrating model, county, and basin boundaries and average annual recharge for water years 1981-2010. 
Snow processes

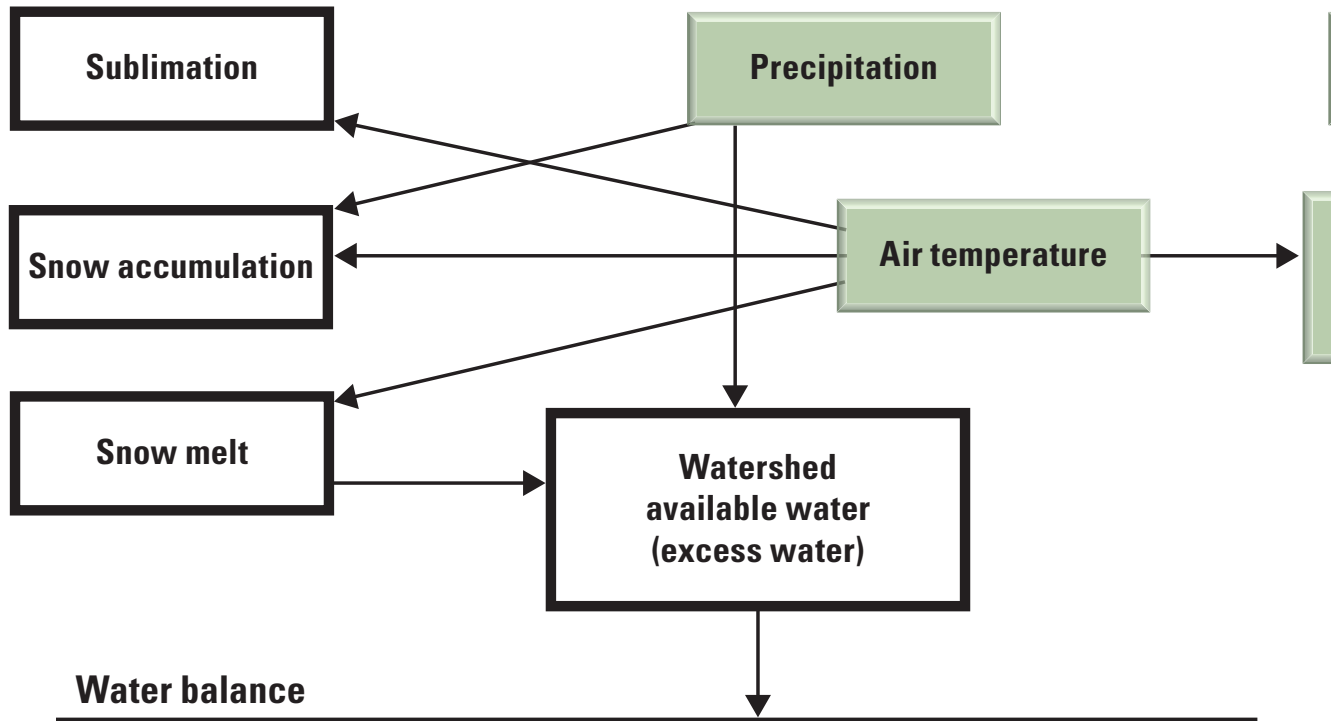

Energy balance

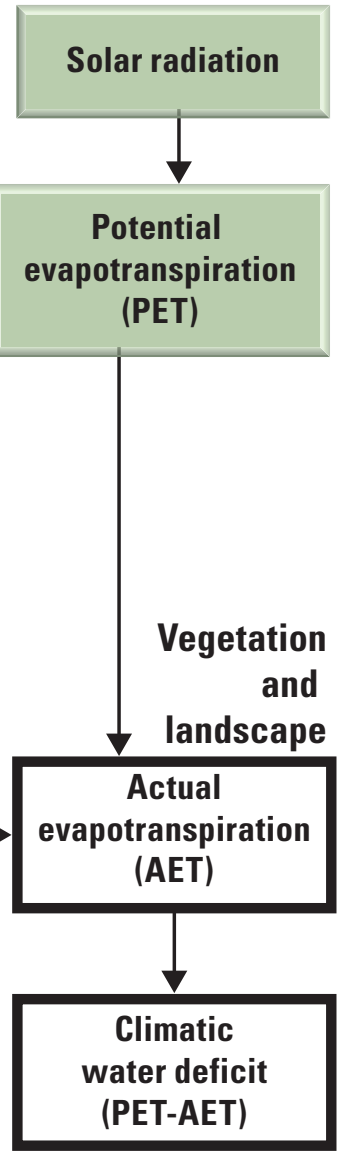

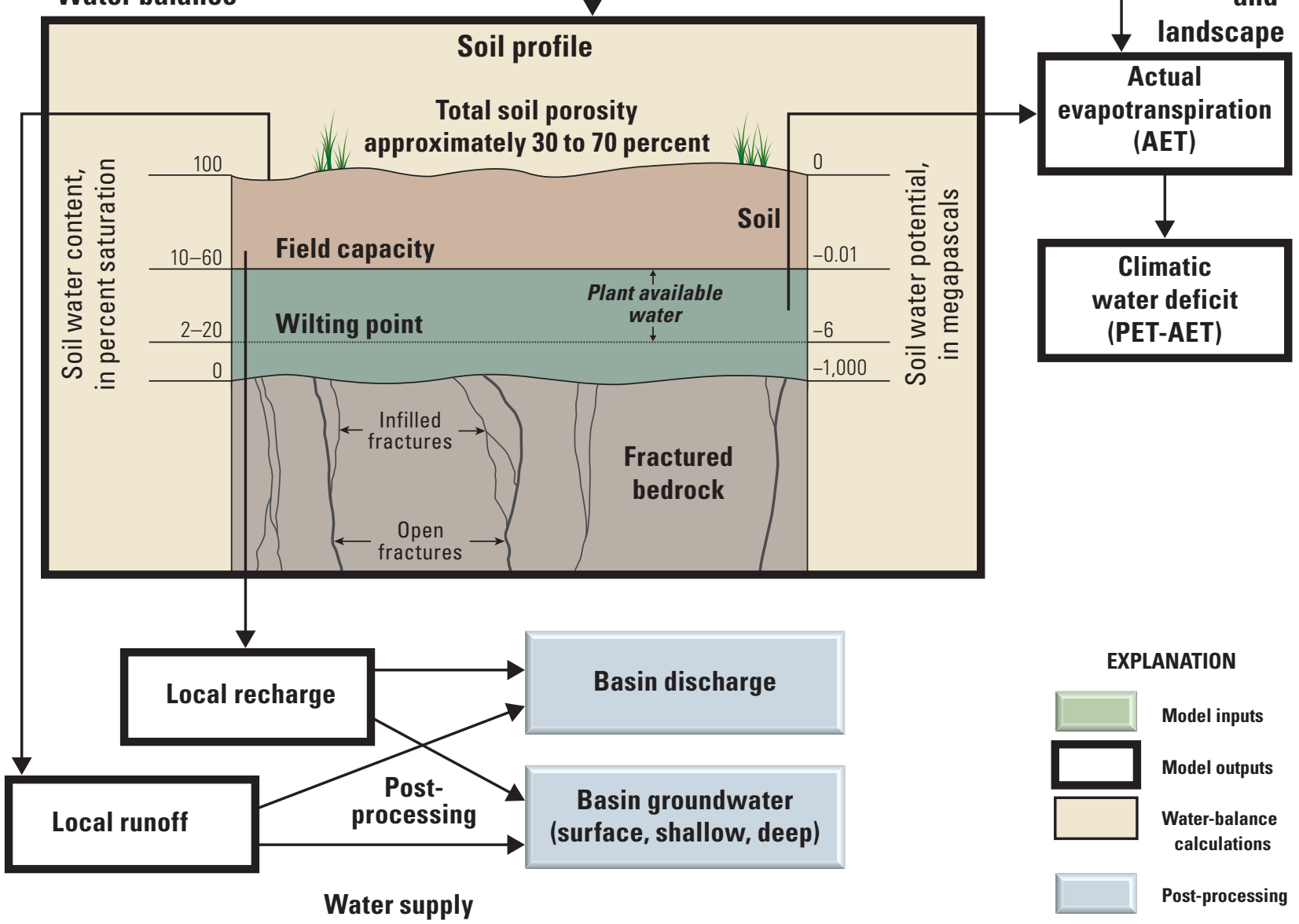

Figure 2. Inputs, outputs, and water-balance components of the Basin Characterization Model (BCM), version 8 (BCMv8). 

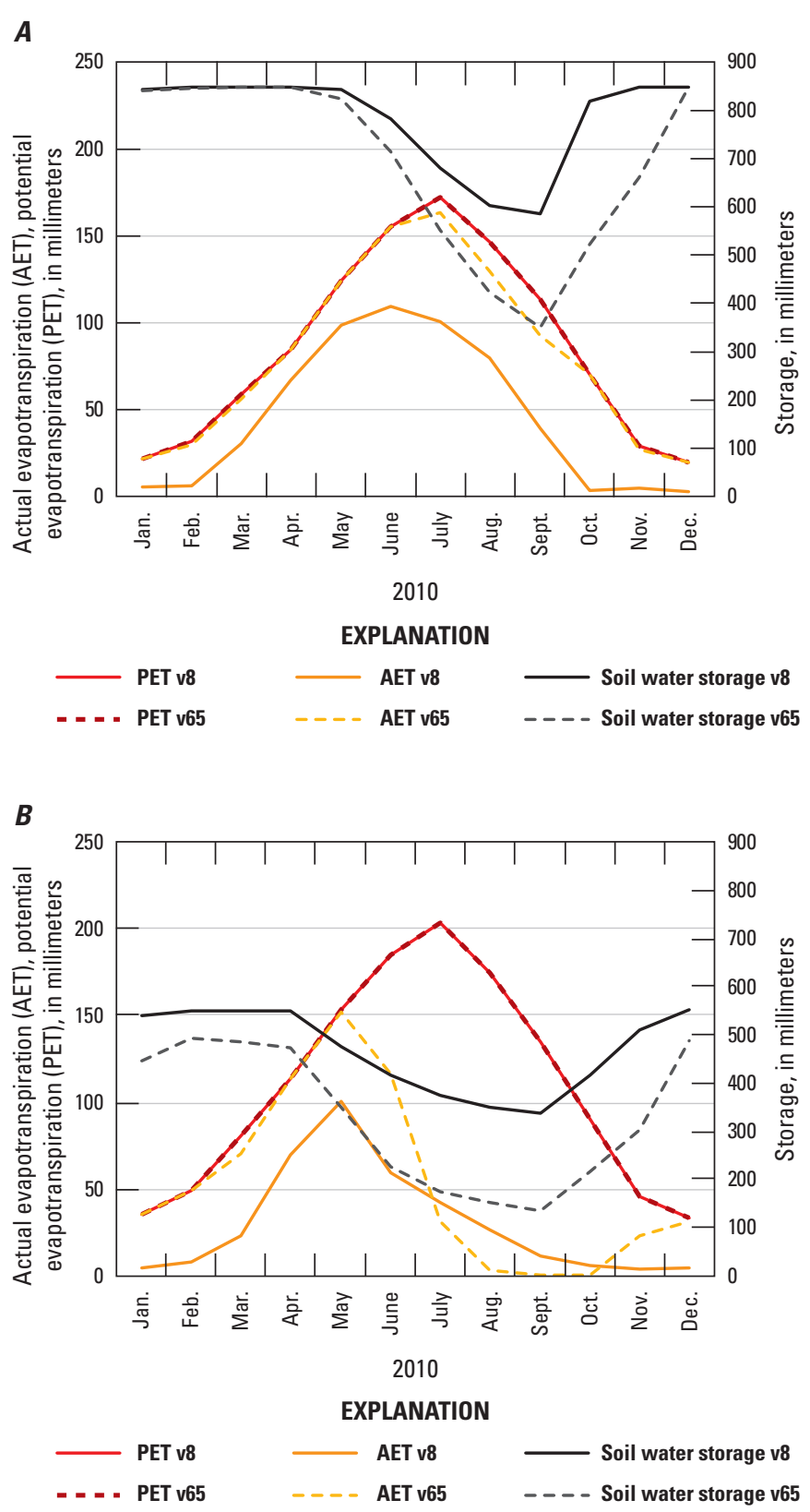

Figure 3. Relations among potential and actual evapotranspiration and soil-water content calculated by the Basin Characterization Model (BCM), version 8, with vegetation and BCM version 6.5 without vegetation: $A$, Douglas fir in the upper Mad River basin and $B$, blue oak woodland in the Merced-Tuolumne basin.

\section{Description of Computer Software Basin Characterization Model}

\section{Conceptual Model of Water Balance}

The water balance of a basin considers all the climatic inputs and hydrologic outputs and changes to be equal to zero for each time step.

\section{Water-Balance Modeling}

In comparison to the water budget of a basin, which incorporates all inputs and outputs, including withdrawals, diversions, and deliveries, the water-balance calculations performed by the BCMv8 represent unimpaired conditions and solve the following equation monthly: precipitation - evapotranspiration - sublimation - runoff - recharge change in soil storage $=0$. On a monthly basis, excess water infiltrates into the soil only when precipitation is greater than PET. The amount of AET of the vegetation, and whether there is snowmelt in a basin, determines how much "supply" could be available throughout the dry season.

The components of the water balance as model inputs and outputs, are shown in figure 2. Model inputs are climate data that have been spatially downscaled to 270-meter (m) grids following Flint and Flint (2012). PET is calculated using a pre-processing FORTRAN code, SolPET, that uses air temperature and a modification of the Priestley-Taylor equation (Flint and Childs, 1991; Priestley and Taylor, 1972) together with topographic shading and cloudiness (Bristow and Campbell, 1984) to calculate hourly PET. Precipitation is run through the Snow-17 module (Anderson, 2006) to calculate snow accumulation and melt, and excess water that moves to the soil profile is calculated. Soil data are used to calculate the soil water-holding capacity and plant-available water. If the monthly excess water exceeds porosity, it becomes runoff. If it exceeds field capacity but is less than porosity, then AET is removed from the plant-available water (between field capacity and wilting point) on the basis of monthly values that scale PET to AET; that is, monthly values of the $\mathrm{K}_{\mathrm{v}}$ coefficient (calculated as AET divided by PET) are determined for specific vegetation types. If soil water storage is still greater than field capacity it becomes recharge at the rate of bedrock conductivity (GeolK) or saturated-soil hydraulic conductivity (Ksat), whichever is less. Climatic water deficit is calculated as PET minus AET. Maps of recharge and runoff are generated for all grid cells in the model and can be used in post-processing to calculate basin discharge for comparison to measured streamflows. 


\section{Recharge and Runoff}

Recharge is defined as water that infiltrates into the soil and percolates below the zone of evapotranspiration (deep percolation) and may proceed to the groundwater aquifer or return to the surface as base flow in streams or discharge in springs. If soils are saturated, precipitation becomes runoff. These hydrologic processes can be generalized and described as having different magnitudes and pathways depending on if the climate is mesic (high precipitation relative to evapotranspiration) or xeric (high evapotranspiration relative to precipitation). Recharge and runoff in a watershed may go into unsaturated bedrock or alluvial deposits in xeric regions, whereas little recharge remains in a mesic watershed but becomes base flow to streams. In watersheds with low-conductivity bedrock, the runoff exceeds recharge, and both leave the watershed early in the wet season, generally winter in California. In permeable watersheds, recharge may exceed runoff and be stored in soils and bedrock longer, extending base flows later into the summer season and contributing to groundwater storage in xeric regions and in mesic regions when multiple dry years have dried the soils and lowered the water table. In mesic climates, which have higher precipitation and lower PET than xeric ones, AET may extend further through the dry season, generally summer in California, whereas soil water is depleted earlier in the season in xeric climates, and AET stops. Correspondingly, recharge and runoff are greater and may extend further into the dry season in mesic climates, especially in areas with snowpack. Alternately, recharge is often greater than runoff in xeric climates because of the high evaporative demand and storage space in soils for water, whereas in areas that have high precipitation, this water may fill soils and create runoff. Whether precipitation becomes recharge or runoff in watershed, therefore, depends on the climate, soil, bedrock geology, and land-cover properties of the specific watershed.

\section{Available Datasets at 270-Meter Spatial Resolution}

The CA-BCM that uses BCMv65 (Flint and others, 2013; Flint and Flint, 2014) is available for California for 1896-2019 with 18 future climates, the Great Basin for 1950-2013 with 12 future climates, the Lower Colorado River Basin for 1940-2010 with 2 future climates for 2071-2100, and the Upper Colorado River Basin for 1940-2010. California and the Great Basin are available through https://ca.water.usgs.gov/projects/reg_hydro/basincharacterization-model.html. The data for the Lower and Upper Colorado River Basins are available upon request.

The BCMv8 improves the water-balance estimates and incorporates vegetation-specific AET. The BCMv8 model for California has been calibrated and run for the 1896-2019 period and run through climate projections from 1950 to 2099 with greenhouse-gas forcings beginning in 2006. Ten Global Climate Models (GCMs) were selected from the full ensemble of models from the fifth experiment of the Coupled Model Intercomparison Project from the World Climate Research Programme (CMIP5; California Department of Water Resources Climate Change Technical Advisory Group, 2015) on the basis of GCM historical performance to address specific needs for California water-resource planning. These 10 GCMs were statistically downscaled using the localized constructed analog (LOCA) method (Pierce and others, 2014) from 2-degree (approximately 222-kilometer; $\mathrm{km}$ ) quadrangles to $6-\mathrm{km}$ resolution and the Livneh historical baseline climate dataset from 1950 to 2005 (Livneh and others, 2013) as a training dataset (Pierce and others, 2014). The LOCA method has been shown to produce better estimates of extreme events and reduces the common downscaling problem of too many low-precipitation days (Pierce and others, 2014). The 20 downscaled futures, representing $10 \mathrm{GCMs}$ with 2 representative concentration pathways each (RCPs 4.5 and 8.5 ; table 1 ), were then spatially downscaled using methods described in Flint and Flint (2012) to a 270-meter (m) resolution for California's Fourth Climate Change Assessment. These model inputs were fed at a monthly time step through the calibrated BCMv8 for California. 
Table 1. Future climate scenarios available for representative concentration pathways 4.5 and 8.5 for California using the Basin Characterization Model, version 8 (BCMv8).

[ID, identification]

\begin{tabular}{|c|c|c|}
\hline Model name & Institute ID & Modeling center or group \\
\hline ACCESS 1.0 & CSIRO-BOM & $\begin{array}{l}\text { Commonwealth Scientific and Industrial Research Organization (CSIRO) and Bureau of Meteorology } \\
\text { (BOM), Australia. }\end{array}$ \\
\hline CanESM2 & CCCMA & Canadian Centre for Climate Modeling and Analysis. \\
\hline CCSM4 & NCAR & National Center for Atmospheric Research, United States of America. \\
\hline CESM1-BGC & NSF-DOE-NCAR & $\begin{array}{l}\text { National Science Foundation (NSF), Department of Energy (DOE), and National Center for } \\
\text { Atmospheric Research (NCAR), United States of America; Community Earth System Model. }\end{array}$ \\
\hline CMCC-CMS & CMCC & Centro Euro-Mediterraneo per I Cambiamenti Climatici. \\
\hline CNRM-CM5 & CNRM-CERFACS & $\begin{array}{l}\text { Centre National de Recherches Météorologiques (CNRM) / Centre Européen de Recherche et } \\
\text { Formation Avancée en Calcul Scientifique (CERFACS), France. }\end{array}$ \\
\hline GFDL-CM3 & NOAA GFDL & $\begin{array}{l}\text { National Oceanic and Atmospheric Administration (NOAA) Geophysical Fluid Dynamics Laboratory } \\
\text { (GFDL), United States of America. }\end{array}$ \\
\hline HadGEM2-CC & $\mathrm{MOHC}$ & Met Office Hadley Centre, United Kingdom. \\
\hline HadGEM2-ES & $\mathrm{MOHC}$ & $\begin{array}{l}\text { Met Office Hadley Centre (additional HadGEM2-ES realizations contributed by Instituto Nacional de } \\
\text { Pesquisas Espaciais), United Kingdom. }\end{array}$ \\
\hline MIROC5 & MIROC & $\begin{array}{l}\text { Atmosphere and Ocean Research Institute (The University of Tokyo), National Institute for } \\
\text { Environmental Studies, and Japan Agency for Marine-Earth Science and Technology. }\end{array}$ \\
\hline
\end{tabular}

\section{Developing a BCMv8 Water Balance for a Basin}

The monthly BCMv8-simulated water balance can be developed for an area or basin of any size or spatial resolution and is only limited by resolution of spatial input data or computing capabilities. For example, models have been developed for the entire Southwest at a 270-m spatial resolution and for University of California Reserves at a 10-m spatial resolution. Climate data can be developed from a variety of sources, including available gridded datasets or station data, and soils and geology data can be obtained from local, regional, or national sources. Another input, actual evapotranspiration, can also be acquired from a variety of sources. For this application, we describe the data sources and the development methodology that have been used for existing BCMs. Our example for this BCMv8 development is for a selection of basins in the Sierra Nevada (Tuolumne and Merced River basins upstream from major Central Valley reservoirs, including a calibration example for the Merced River basin upstream from USGS streamgage 11264500 Merced River at Happy Isles; fig. 4) for a model grid that is at a 270-meter spatial resolution in the California (Teale) Albers equal-area conic projection referenced to the North American Datum of 1983 (NAD83). The control file that the BCMv8 reads for timing, filenames, and parameterization instructions for the Merced-Tuolumne model is listed in appendix 1 and is described in detail in sections that follow. The detailed step-by-step procedure for developing a BCMv8 simulation is in appendix 2. Descriptions of all components follow.

\section{Input Files}

The BCMv8 relies on a series of static property layer files (table 2); monthly time series of climate files as input, including potential evapotranspiration (table 3); and lookup tables for model parameterization. All files are in ASCII text format and need to be exactly the dimension and resolution of the digital elevation model (DEM). Layer filenames (table 2) and lookup tables are identified in the control file (BCM_Monthlyv8.ctl; appendix 2). Our example for the BCMv8 development for the Tuolumne and Merced River basins uses as a filename convention the two-letter-prefix basin identifier "MT" for all layer files (see appendix 2). Another prefix example is "CA" for California, as indicated in table 2 filenames. These files are for a model grid that has a 270-meter spatial resolution. 


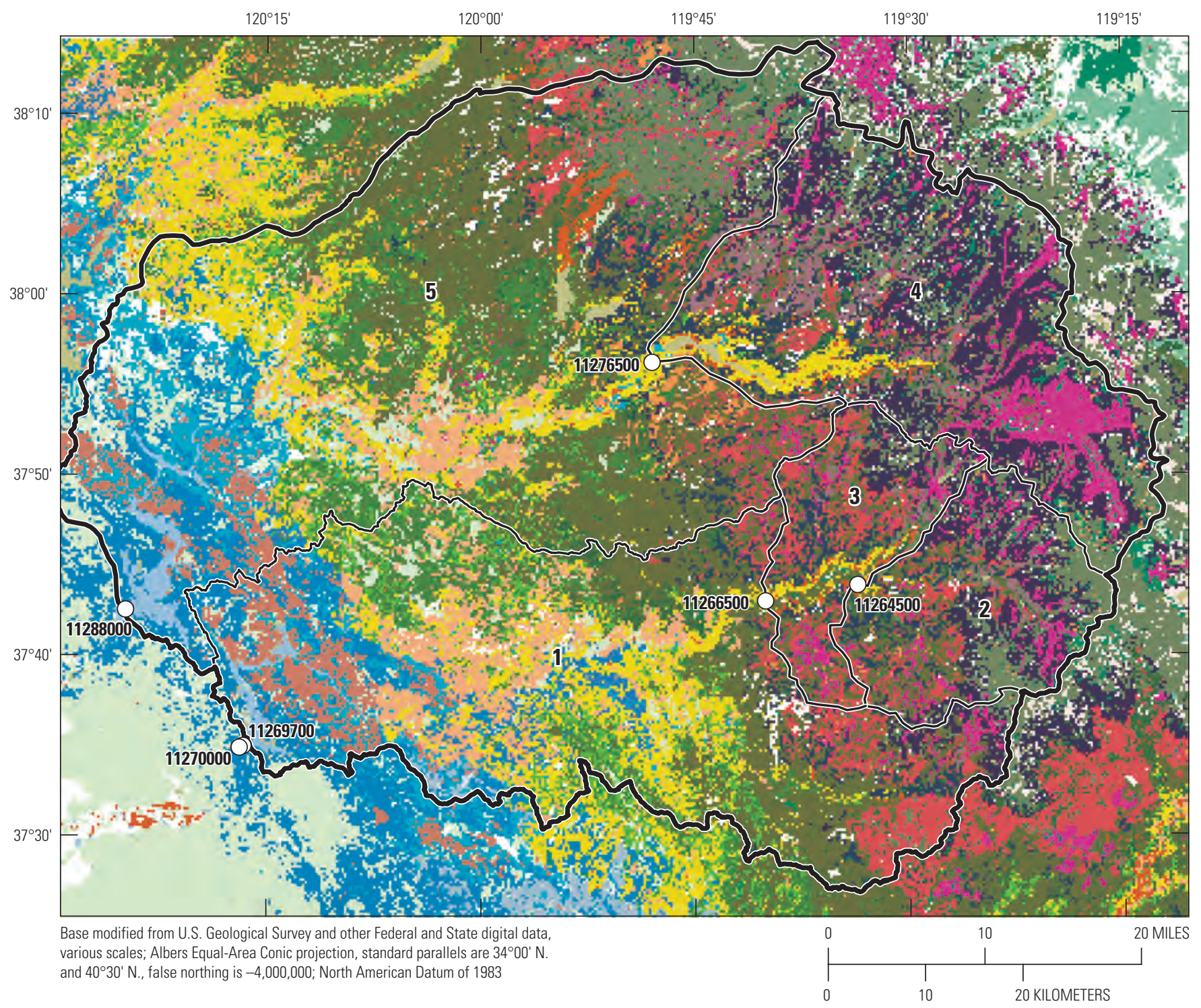

EXPLANATION

\begin{tabular}{|c|c|c|}
\hline \multicolumn{3}{|c|}{$\begin{array}{l}\text { Vegetation types (Fire Resource and Assessment Program, FRAP; } \\
\text { https://frap.fire.ca.gov/data/frapgisdata-land_cover) }\end{array}$} \\
\hline Alpine-dwarf shrub & Lodgepole pine & Subalpine conifer \\
\hline Annual grassland & Mixed chaparral & Sagebrush \\
\hline Barren & Montane chaparral & Sierran mixed conifer \\
\hline Blue oak-foothill pine & Montane hardwood- & Wet meadow \\
\hline Blue oak woodland & cominer & Rock cliff scree \\
\hline Chamise-redshank & Montane hardwood & Annual grassland north \\
\hline chaparral & Perennial grassland & Mixed chaparral south \\
\hline Jeffrey pine & Ponderosa pine & Mentane hardwend \\
\hline Juniper & Riverine & south \\
\hline Lacustrine & Red fir & \\
\hline
\end{tabular}

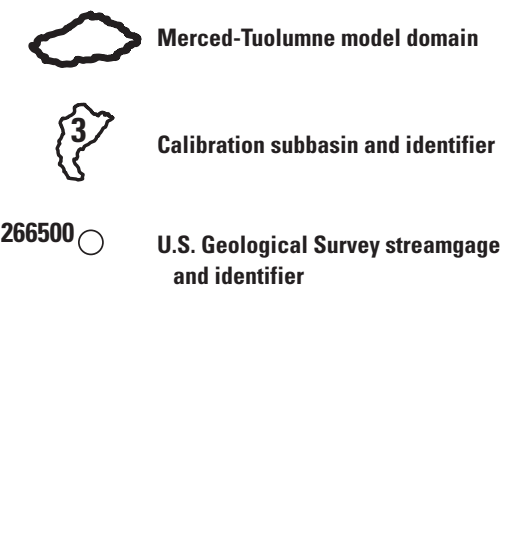

Figure 4. Merced-Tuolumne model domain, including basin boundaries for the Merced River upstream from U.S. Geological Survey (USGS) streamgages 11264500 Merced River at Happy Isles (basin 2), 11266500 Merced River upstream from Pohono (basin 3), California Data Exchange Center (CDEC) full natural flows for Exchequer Reservoir (basin 1), Tuolumne River upstream from streamgage 11276500 near Hetch Hetchy (basin 4), and CDEC full natural flows for Don Pedro Reservoir (basin 5). Map includes vegetation types for the model domain. 
Table 2. List of files for static-property inputs (layer files) required to run the Basin Characterization Model, version 8 (BCMv8). Optional files are dependent on switch settings. Soil properties may be used to develop soil hydraulic properties if developing new model.

[BCM, Basin Characterization Model; DEM, digital elevation model; m, meter; SSURGO, Soil Survey Geographic Database; AET, actual evapotranspiration; $\mathrm{MPa}$, megapascals; $\mathrm{g} / \mathrm{cm}^{3}$, grams per cubic centimeter; $\mathrm{mm} /$ day, millimeters per day; GEOL, BCMv8 control file switch allowing user to use a bedrock conductivity map rather than LOOKUP table 1; FLOOD, BCMv8 control file switch allowing user to read in maps where managed aquifer recharge will be tested; SNOW, BCMv8 control file switch allowing user to a single value for snow parameters rather than use maps of spatially distributed parameters; $\mathrm{RCH} / \mathrm{RUN}, \mathrm{BCMv} 8$ control file switch to enable user to increase or decrease the relative amount of recharge or runoff in streams; MASK, BCMv8 switch that allows a user to block out areas in printed maps and summarized outfile time series.]

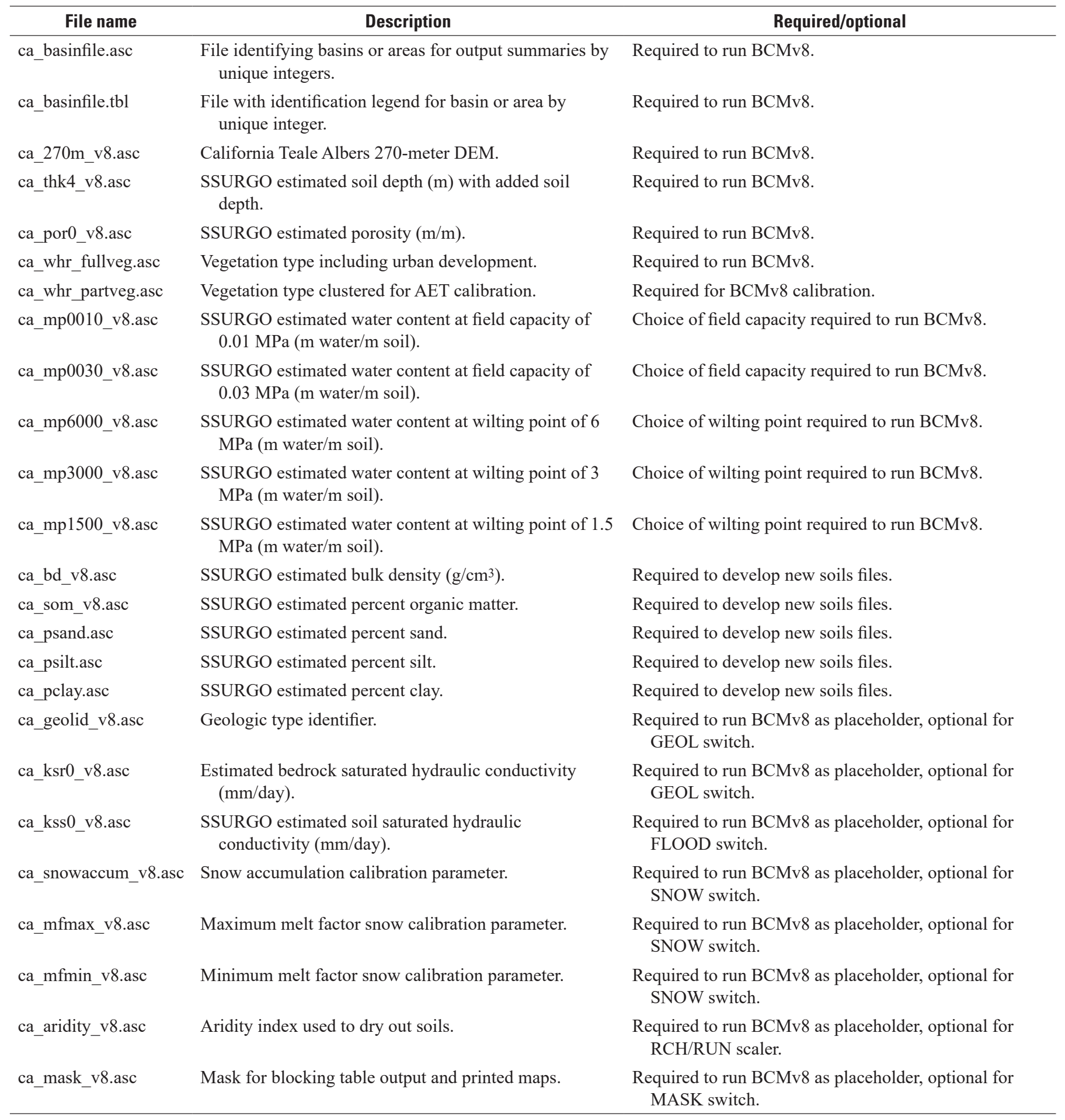


Table 3. List of files for gridded time-series inputs required to run the Basin Characterization Model, version 8 (BCMv8), where $\mathrm{mmm}$ in the file name refers to the 3 -letter abbreviation for each month.

[mm, millimeter; ${ }^{\circ} \mathrm{C}$, degrees Celsius $]$

\begin{tabular}{cc}
\hline \multicolumn{1}{c}{ File name } & Description \\
\hline pptYYYYmmm.asc & $\begin{array}{c}\text { monthly precipitation }(\mathrm{mm}) \text { for years } \\
\text { (YYYY) and months }(\mathrm{mmm}) .\end{array}$ \\
tmnYYYYmmm.asc & $\begin{array}{c}\text { monthly minimum air temperature }\left({ }^{\circ} \mathrm{C}\right) \text { for } \\
\text { years (YYYY) and months }(\mathrm{mmm}) .\end{array}$ \\
tmxYYYYmmm.asc & $\begin{array}{c}\text { monthly maximum air temperature }\left({ }^{\circ} \mathrm{C}\right) \text { for } \\
\text { years (YYYY) and months }(\mathrm{mmm}) .\end{array}$ \\
petYYYYmmm.asc & $\begin{array}{c}\text { monthly potential evapotranspiration for } \\
\text { years (YYYY) and months }(\mathrm{mmm}) .\end{array}$ \\
\hline
\end{tabular}

These files are developed using publicly available datasets from USGS (Digital Elevation Model, DEM: https://viewer.nationalmap.gov; National Hydrography Dataset, NHD: https://nhd.usgs.gov/), Natural Resources Conservation Service (NRCS, Soil Survey Geographic Database, SSURGO: https://websoilsurvey.nrcs.usda.gov/), state or local geologic maps (California, https://maps.conservation.ca.gov/cgs/gmc/), and collaborative land-cover datasets (National Land Cover Database, NLCD: https://www.mrlc.gov/; Fire Resource and Assessment Program, FRAP: https://egis.fire.ca.gov/arcgis/ rest/services/FRAP/fveg_WHRTYPE/MapServer/layers). Files that are labeled optional (table 2) depend on whether or not the operational switch is on. Snow accumulation and melt are calculated using the Snow-17 model (Anderson, 2006), and parameters can be developed for specific sites using local snow-sensor or snow-course information and the control file options (appendix 1; see Anderson, 2006, for guidance with snow calibrations), or if a study basin is in California, the three maps representing spatially distributed snow parameters that have been developed from statewide calibration to 120 snow courses can be clipped and applied.

The basin file (mt_basinfile.asc) is developed to summarize the spatial data by averaging (temperature) or summing (all water variables) for each month for zones (integer-defined areas of the basin layer), such as all grid cells upstream from a streamgage or reservoir, watersheds, geopolitical boundaries, or for gridded vegetation types, in order to calculate monthly and annual (water year) time series of all input and output variables. The table file (mt_basinfile.tbl) allows the user to create labels for your integer-defined basins or areas and is used by the model to read the gridded basin file. Both mt_whr_fullveg.asc and $\mathrm{mt}$ whr_partveg.asc are vegetation files that are used one at a time in the control file. The file mt_whr_partveg.asc has been processed in ArcGIS (Environmental Systems Research Institute, 2017) with a grouping analysis to enable the comparison of large areas of contiguous vegetation types
Table 4. List of files for average monthly climate inputs required to run the Basin Characterization Model, version 8 (BCMv8), where $\mathrm{mmm}$ in the file name refers to the 3-letter abbreviation for each month.

[mm, millimeters]

\begin{tabular}{|c|c|}
\hline File name & Description \\
\hline pptavemmm.asc & $\begin{array}{l}12 \text { files of average monthly precipitation, } \\
\text { in mm per month, for months (mmm), } \\
\text { averaged for 1981-2010, and used for actual } \\
\text { evapotranspiration calibration. }\end{array}$ \\
\hline radavemmm.asc & $\begin{array}{l}12 \text { files of average monthly solar radiation, in } \\
\text { megajoules per month, for months ( } \mathrm{mmm} \text { ), } \\
\text { used if SOLAR switch is on. }\end{array}$ \\
\hline pptaveann.asc & $\begin{array}{l}\text { Average 30-year water-year precipitation, in mm } \\
\text { per year (1981-2010). }\end{array}$ \\
\hline fldavemmm.asc & $\begin{array}{l}12 \text { files of flooded conditions for months } \\
(\mathrm{mmm}) \text {, used if FLOOD switch is on. }\end{array}$ \\
\hline
\end{tabular}

to sample measured actual evapotranspiration data that is available at 1-km spatial resolution for comparison to BCMv8 estimated AET. Any source of spatial estimates of actual evapotranspiration can be used. Parameters for actual evapotranspiration are shown in the vegetation lookup table (LOOKUP table 2; appendix 1), which can be used as default or locally calibrated and adjusted (see appendix 3 ).

Time-series inputs are from available gridded climate files (sources include PRISM: www.prism.oregonstate.edu/, Daymet: https://daymet.ornl.gov/, Livneh: https://www.esrl. noaa.gov/psd/data/gridded/data.livneh.html, WorldClim: www.worldclim.org/, VIC: https://rdrr.io/cran/VICmodel/). Monthly PET maps can be obtained from various sources (Szilágyi and others, 2011, CREMAP, http://snr.unl.edu/ data/water/evapotranspiration/statewideet.aspx; Willmott and Kenyi, 2001, www.nelson.wisc.edu/sage/data-andmodels/atlas $/$ maps.php?datasetid=46\&includerelatedlinks= $1 \&$ dataset=46). Maps of average monthly precipitation (table 4) are generated from monthly time-series files for whatever time span is considered the long-term mean. Average solar-radiation maps can be used from available 270-m grids from the California BCMv8 model, or generated from National Solar Radiation Data Base (NREL; Sengupta and others, 2014) or California Irrigation Management Information System (CIMIS, https://cimis.water.ca.gov/) stations, or using the FORTRAN code Solrad (Flint and Childs, 1987), which requires the DEM and air temperature maps. Lookup tables for bedrock conductivity by mapped geology (LOOKUP table 1; appendix 1, table 5) and vegetation type with evapotranspiration parameters (LOOKUP table 2; appendix 1, table 6) are provided with default parameters that are based on the California statewide calibration and can be changed as necessary to achieve desired calibration results. 


\section{The Basin Characterization Model—A Regional Water Balance Software Package}

Table 5. LOOKUP table 1 (in control file), list of geology types with identifiers (Geol ID) and default bedrock conductivity values (Ks).

[mm/day, millimeter per day]

\begin{tabular}{|c|c|c|}
\hline Geol ID & $\begin{array}{c}\text { Ks } \\
(\mathrm{mm} / \text { day })\end{array}$ & Geology \\
\hline 1 & 500 & Alluvium - ash \\
\hline 2 & 200 & Alluvium - channels \\
\hline 3 & 500 & Alluvium - eolian sand \\
\hline 4 & 40 & Alluvium - glacial till \\
\hline 5 & 10 & Alluvium - desert fill \\
\hline 6 & 0.27 & Alluvium - lake sediments \\
\hline 7 & 500 & Alluvium - landslides \\
\hline 8 & 55 & Alluvium - marshes \\
\hline 9 & 2.74 & Alluvium - mud and salt flats \\
\hline 10 & 20 & Alluvium - older upland soils \\
\hline 11 & 0.82 & Alluvium - playas \\
\hline 12 & 200 & Alluvium - valley fill \\
\hline 13 & 100 & Carbonates - dolomite \\
\hline 15 & 90 & Carbonates - limestone \\
\hline 16 & 0.27 & Carbonates - travertine \\
\hline 17 & 1 & Chert \\
\hline 18 & 20 & Conglomerate \\
\hline 19 & 0.5 & Gabbro \\
\hline 20 & 15 & Granite \\
\hline 21 & 0.6 & Granite - granodiorite \\
\hline 22 & 40 & Granite - mixed \\
\hline 23 & 14 & Granite - quartz monzonite \\
\hline 24 & 27.4 & Igneous - diabase \\
\hline 25 & 0.27 & Igneous - dikes and plugs \\
\hline 26 & 2 & Metamorphics - gneiss/schist \\
\hline 27 & 2 & Metamorphics - phyllite \\
\hline 28 & 38 & Metamorphics - serpentinite \\
\hline
\end{tabular}

Table 5. LOOKUP table 1 (in control file), list of geology types with identifiers (Geol ID) and default bedrock conductivity values (Ks).-Continued

[mm/day, millimeter per day]

\begin{tabular}{ccl}
\hline Geol ID & $\begin{array}{c}\text { Ks } \\
\text { (mm/day) }\end{array}$ & \multicolumn{1}{c}{ Geology } \\
\hline 29 & 2 & Metasediments \\
30 & 1.5 & Metavolcanics \\
31 & 0.05 & Quartzite \\
32 & 6 & Sandstone \\
42 & 0.1 & Sandstone - claystone \\
43 & 1 & Sandstone - fine \\
44 & 3 & Sandstone - shale \\
45 & 0.9 & Sandstone - siltstone \\
46 & 2 & Sedimentary - coastal belt \\
47 & 2 & Sedimentary \\
48 & 0.27 & Volcanics - andesites \\
49 & 1 & Volcanics - andesites (flows and breccias) \\
50 & 6 & Volcanics - ash-flow tuffs \\
51 & 32 & Volcanics - basalts \\
52 & 0.27 & Volcanics - breccias \\
53 & 6 & Volcanics - lava flows \\
54 & 0 & No Geology \\
55 & 8 & Volcanics - lava flows Quaternary \\
56 & 20 & Volcanics - pyroclastics \\
57 & 0.5 & Volcanics - rhyolites \\
58 & 0 & Water \\
59 & 1.2 & Sandstone - claystone mélange \\
60 & 0.3 & Sandstone - shale Eocene \\
61 & 0.1 & Sandstone - shale lower \\
62 & 0.2 & Sandstone - shale upper \\
63 & 15 & Volcanics - lava flows Tertiary \\
64 & 200 & Sandstone - Santa Margarita \\
\hline & &
\end{tabular}


The parameters listed in table 6 (see also appendix 1) are defaults based on a statewide calibration that averages the values for all locations of a vegetation type in California. The monthly $\mathrm{K}_{\mathrm{v}}$ are developed for each vegetation type using gridded AET estimates divided by PET for each month and averaged for the measurement period. In this case, we have used the gridded AET dataset available from Reitz and others (2017; referred to as ETa) for October 2000 through September 2015. RootDepth is a calibration parameter that allows you to increase the depth of soil to simulate storage of water below the mapped soil depth that may be accessed by roots of vegetation and is necessary to match the BCMv8-derived AET to the estimated monthly ETa data. The vegetation density parameter LAI is a parameter related to what is commonly called a leaf area index but scaled to 1 to allow for calculations of vegetation density. As used in the model, it is in equilibration with the average climate at a value of 1.000 , which is used for calibration under current conditions. LAI can be adjusted to impose disturbance and reduction of vegetation density in disturbance mode. If a vegetation type is sensitive to annual variations in precipitation, the UpRate and DnRate variables are used to change the sensitivity to match the measured data. Density parameters UpLimit and DnLimit define the upper and lower limits of the range within which the maximum yearly LAI can vary as a result of variability of climate. Redwood (VegID=44), for example, is not very sensitive to changes in precipitation and has a narrow range of limits and rates, whereas blue oak woodland (VegID $=9$ ) is very sensitive and has a broader range of limits, growing more (increasing LAI and AET) in years with more precipitation. When doing a local calibration, or developing a new model with other estimates of AET, new monthly $\mathrm{K}_{\mathrm{v}}$ values are developed as AET divided by PET for each month for each vegetation type; then, if necessary to increase modeled AET to improve the match with measured estimates, RootDepth would be increased from an initial value of 0 . Then the growth parameters would be changed from initial values of LAI, UpLimit, and DnLimit equal to 1.000, and UpRate and DnRate equal to 0.000, to reflect responsiveness of vegetation types to changes in climate. These variables can also be used to simulate onset of disturbance, such as fire or forest management, to simulate regrowth or replacement of vegetation type and thereby to analyze disturbance effects on hydrology (see application 2).

Table 6. LOOKUP table 2 (in control file), list of vegetation types with identifiers (Veg ID), density and growth parameters, and monthly $\mathrm{K}_{\mathrm{v}}$ values to calculate actual evapotranspiration for the California statewide calibration.

[WHR, wildlife habitat relationships; Veg ID, vegetation identification; LAI, relative leaf area index used for changing density for disturbance analysis; UpLimit, upperlimit; DnLimit, lower limit; UpRate, upper sensitivity; DnRate, lower sensitivity; x, facultative; —, non-facultative]

\begin{tabular}{|c|c|c|c|c|c|c|c|c|c|c|}
\hline \multirow{2}{*}{$\begin{array}{l}\text { WHR } \\
\text { TYPE }\end{array}$} & \multirow{2}{*}{$\begin{array}{l}\text { Veg } \\
\text { ID }\end{array}$} & \multicolumn{6}{|c|}{ Density and growth parameters } & \multirow{2}{*}{ Vegetation type } & \multirow{2}{*}{$\begin{array}{c}\text { Parameters } \\
\text { assigned }\end{array}$} & \multirow{2}{*}{ Facultative } \\
\hline & & LAI & UpLimit & DnLimit & UpRate & DnRate & Root depth & & & \\
\hline ADS & 1 & 1.000 & 1.800 & 0.750 & 1.400 & 0.850 & 0.250 & Alpine-dwarf shrub & ADS & $\mathrm{x}$ \\
\hline AGS & 3 & 1.000 & 1.600 & 0.750 & 2.000 & 0.200 & 1.500 & Annual grassland & AGS & $\mathrm{x}$ \\
\hline ASC & 4 & 1.000 & 1.500 & 0.950 & 2.000 & 0.600 & 0.500 & Alkali desert scrub & ASC & $\mathrm{x}$ \\
\hline ASP & 5 & 1.000 & 2.100 & 0.900 & 1.900 & 0.750 & 0.200 & Aspen & ASP & - \\
\hline BAR & 6 & 1.000 & 1.000 & 0.950 & 1.100 & 0.950 & 0.000 & Barren & BAR & - \\
\hline BBR & 7 & 1.000 & 1.500 & 0.850 & 1.300 & 0.900 & 0.000 & Bitterbrush & BBR & $\mathrm{x}$ \\
\hline BOP & 8 & 1.000 & 1.750 & 0.900 & 1.400 & 0.750 & 1.250 & Blue oak-foothill pine & BOP & - \\
\hline BOW & 9 & 1.000 & 1.500 & 0.750 & 1.600 & 0.400 & 1.000 & Blue oak woodland & BOW & $\mathrm{x}$ \\
\hline COW & 10 & 1.000 & 1.200 & 1.000 & 1.100 & 0.950 & 0.300 & Coastal oak woodland & COW & - \\
\hline $\mathrm{CPC}$ & 11 & 1.000 & 1.400 & 0.950 & 1.100 & 0.500 & 0.700 & Closed-cone pine-cypress & $\mathrm{CPC}$ & - \\
\hline $\mathrm{CRC}$ & 12 & 1.000 & 2.100 & 0.900 & 1.700 & 0.100 & 1.400 & Chamise-redshank chaparral & $\mathrm{CRC}$ & $\mathrm{x}$ \\
\hline $\mathrm{CSC}$ & 13 & 1.000 & 2.200 & 0.900 & 2.000 & 0.300 & 1.600 & Coastal scrub & $\mathrm{CSC}$ & $\mathrm{x}$ \\
\hline DFR & 14 & 1.000 & 1.000 & 0.950 & 1.000 & 0.975 & 1.000 & Douglas fir & DFR & - \\
\hline DRI & 15 & 1.000 & 1.000 & 1.000 & 1.000 & 1.000 & 0.000 & Desert riparian & DRI & - \\
\hline DSC & 17 & 1.000 & 3.600 & 0.950 & 2.000 & 0.100 & 1.000 & Desert scrub & DSC & $\mathrm{x}$ \\
\hline DSS & 18 & 1.000 & 2.000 & 0.950 & 2.100 & 0.700 & 0.250 & Desert succulent shrub & DSS & $\mathrm{x}$ \\
\hline DSW & 19 & 1.000 & 1.900 & 0.950 & 2.100 & 0.300 & 1.500 & Desert wash & DSW & $\mathrm{x}$ \\
\hline EPN & 20 & 1.000 & 1.500 & 0.850 & 1.600 & 0.400 & 1.100 & Eastside pine & EPN & - \\
\hline EST & 21 & 1.000 & 1.000 & 1.000 & 1.000 & 1.000 & 0.000 & Estuarine & EST & - \\
\hline FEW & 22 & 1.000 & 1.000 & 1.000 & 1.000 & 1.000 & 0.000 & Fresh emergent wetland & FEW & - \\
\hline JPN & 24 & 1.000 & 1.300 & 0.950 & 1.200 & 0.900 & 0.700 & Jeffrey pine & JPN & - \\
\hline
\end{tabular}


Table 6. LOOKUP table 2 (in control file), list of vegetation types with identifiers (Veg ID), density and growth parameters, and monthly $\mathrm{K}_{\mathrm{v}}$ values to calculate actual evapotranspiration for the California statewide calibration.-Continued

[WHR, wildlife habitat relationships; Veg ID, vegetation identification; LAI, relative leaf area index used for changing density for disturbance analysis; UpLimit, upperlimit; DnLimit, lower limit; UpRate, upper sensitivity; DnRate, lower sensitivity; x, facultative; —, non-facultative]

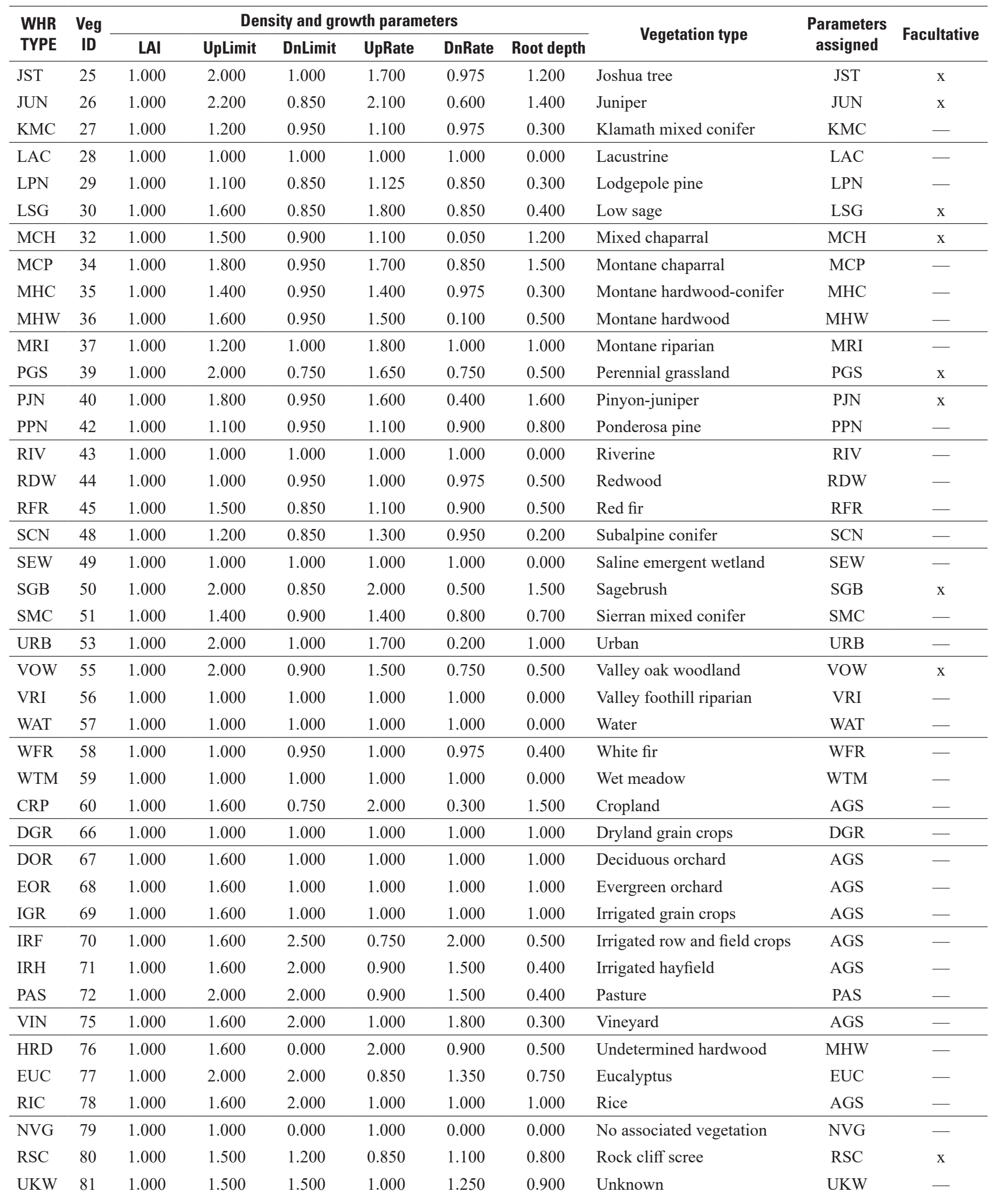


Table 6. LOOKUP table 2 (in control file), list of vegetation types with identifiers (Veg ID), density and growth parameters, and monthly $\mathrm{K}_{\mathrm{v}}$ values to calculate actual evapotranspiration for the California statewide calibration.-Continued

[WHR, wildlife habitat relationships; Veg ID, vegetation identification; LAI, relative leaf area index used for changing density for disturbance analysis; UpLimit, upperlimit; DnLimit, lower limit; UpRate, upper sensitivity; DnRate, lower sensitivity; $x$, facultative; —, non-facultative ]

\begin{tabular}{|c|c|c|c|c|c|c|c|c|c|c|c|c|c|}
\hline \multirow{2}{*}{$\begin{array}{l}\text { WHR } \\
\text { TYPE }\end{array}$} & \multirow{2}{*}{$\begin{array}{l}\text { Veg } \\
\text { ID }\end{array}$} & \multicolumn{12}{|c|}{ Monthly Kfactors for vegetation types } \\
\hline & & Oct & Nov & Dec & Jan & Feb & Mar & Apr & May & Jun & Jul & Aug & Sep \\
\hline ADS & 1 & 0.214 & 0.139 & 0.048 & 0.077 & 0.212 & 0.262 & 0.426 & 0.365 & 0.340 & 0.213 & 0.197 & 0.227 \\
\hline AGS & 3 & 0.199 & 0.160 & 0.280 & 0.224 & 0.598 & 0.780 & 0.782 & 0.619 & 0.546 & 0.524 & 0.057 & 0.325 \\
\hline ASC & 4 & 0.066 & 0.086 & 0.125 & 0.142 & 0.193 & 0.445 & 0.568 & 0.626 & 0.516 & 0.391 & 0.290 & 0.164 \\
\hline ASP & 5 & 0.074 & 0.222 & 0.132 & 0.050 & 0.025 & 0.180 & 0.457 & 0.410 & 0.350 & 0.364 & 0.295 & 0.128 \\
\hline BAR & 6 & 0.005 & 0.064 & 0.102 & 0.060 & 0.015 & 0.008 & 0.009 & 0.013 & 0.020 & 0.012 & 0.003 & 0.018 \\
\hline BBR & 7 & 0.028 & 0.171 & 0.378 & 0.379 & 0.259 & 0.428 & 0.230 & 0.239 & 0.277 & 0.212 & 0.123 & 0.045 \\
\hline BOP & 8 & 0.122 & 0.112 & 0.100 & 0.147 & 0.142 & 0.323 & 0.455 & 0.618 & 0.576 & 0.492 & 0.410 & 0.278 \\
\hline BOW & 9 & 0.048 & 0.062 & 0.090 & 0.102 & 0.123 & 0.321 & 0.410 & 0.452 & 0.372 & 0.282 & 0.210 & 0.118 \\
\hline COW & 10 & 0.060 & 0.078 & 0.112 & 0.128 & 0.154 & 0.401 & 0.512 & 0.565 & 0.465 & 0.353 & 0.262 & 0.147 \\
\hline СРC & 11 & 0.415 & 0.348 & 0.233 & 0.417 & 0.510 & 0.676 & 0.722 & 0.897 & 0.949 & 0.875 & 0.819 & 0.627 \\
\hline CRC & 12 & 0.153 & 0.162 & 0.233 & 0.307 & 0.396 & 0.749 & 0.779 & 0.861 & 0.842 & 0.693 & 0.556 & 0.366 \\
\hline $\mathrm{CSC}$ & 13 & 0.105 & 0.100 & 0.226 & 0.280 & 0.368 & 0.601 & 0.601 & 0.508 & 0.450 & 0.381 & 0.291 & 0.165 \\
\hline DFR & 14 & 0.048 & 0.181 & 0.145 & 0.255 & 0.204 & 0.543 & 0.794 & 0.794 & 0.706 & 0.617 & 0.573 & 0.353 \\
\hline DRI & 15 & 0.176 & 0.175 & 0.192 & 0.146 & 0.165 & 0.292 & 0.287 & 0.410 & 0.531 & 0.604 & 0.545 & 0.388 \\
\hline DSC & 17 & 0.314 & 0.243 & 0.265 & 0.174 & 0.196 & 0.347 & 0.360 & 0.510 & 0.600 & 0.600 & 0.510 & 0.461 \\
\hline DSS & 18 & 0.002 & 0.013 & 0.034 & 0.051 & 0.076 & 0.161 & 0.060 & 0.014 & 0.005 & 0.004 & 0.012 & 0.019 \\
\hline DSW & 19 & 0.043 & 0.042 & 0.197 & 0.224 & 0.129 & 0.231 & 0.184 & 0.188 & 0.217 & 0.215 & 0.189 & 0.119 \\
\hline EPN & 20 & 0.070 & 0.054 & 0.157 & 0.480 & 0.289 & 0.434 & 0.268 & 0.193 & 0.227 & 0.259 & 0.250 & 0.199 \\
\hline EST & 21 & 0.439 & 0.210 & 0.137 & 0.219 & 0.410 & 0.357 & 0.536 & 0.556 & 0.708 & 0.722 & 0.710 & 0.607 \\
\hline FEW & 22 & 0.356 & 0.309 & 0.239 & 0.166 & 0.334 & 0.385 & 0.375 & 0.497 & 0.575 & 0.524 & 0.478 & 0.435 \\
\hline JPN & 24 & 0.102 & 0.073 & 0.169 & 0.492 & 0.211 & 0.373 & 0.229 & 0.238 & 0.281 & 0.286 & 0.262 & 0.219 \\
\hline JST & 25 & 0.521 & 0.472 & 0.138 & 0.337 & 0.282 & 0.548 & 0.478 & 0.503 & 0.524 & 0.521 & 0.521 & 0.521 \\
\hline JUN & 26 & 0.026 & 0.234 & 0.221 & 0.428 & 0.430 & 0.544 & 0.358 & 0.497 & 0.427 & 0.260 & 0.144 & 0.058 \\
\hline $\mathrm{KMC}$ & 27 & 0.234 & 0.176 & 0.128 & 0.321 & 0.300 & 0.464 & 0.475 & 0.555 & 0.558 & 0.609 & 0.580 & 0.459 \\
\hline LAC & 28 & 0.644 & 0.603 & 0.542 & 0.753 & 0.799 & 0.898 & 0.845 & 0.932 & 0.955 & 0.920 & 0.905 & 0.848 \\
\hline LPN & 29 & 0.074 & 0.140 & 0.113 & 0.197 & 0.158 & 0.421 & 0.563 & 0.591 & 0.435 & 0.384 & 0.369 & 0.229 \\
\hline LSG & 30 & 0.040 & 0.052 & 0.028 & 0.099 & 0.092 & 0.191 & 0.303 & 0.136 & 0.106 & 0.111 & 0.109 & 0.086 \\
\hline $\mathrm{MCH}$ & 32 & 0.036 & 0.035 & 0.120 & 0.179 & 0.116 & 0.186 & 0.154 & 0.196 & 0.239 & 0.184 & 0.143 & 0.094 \\
\hline $\mathrm{MCP}$ & 34 & 0.060 & 0.058 & 0.205 & 0.448 & 0.217 & 0.385 & 0.255 & 0.230 & 0.285 & 0.321 & 0.279 & 0.184 \\
\hline MHC & 35 & 0.112 & 0.096 & 0.446 & 0.539 & 0.260 & 0.268 & 0.180 & 0.191 & 0.227 & 0.224 & 0.214 & 0.193 \\
\hline MHW & 36 & 0.092 & 0.074 & 0.202 & 0.255 & 0.146 & 0.198 & 0.159 & 0.169 & 0.206 & 0.187 & 0.188 & 0.164 \\
\hline MRI & 37 & 0.096 & 0.081 & 0.107 & 0.158 & 0.163 & 0.207 & 0.214 & 0.293 & 0.342 & 0.341 & 0.302 & 0.206 \\
\hline PGS & 39 & 0.033 & 0.100 & 0.114 & 0.217 & 0.260 & 0.389 & 0.314 & 0.374 & 0.329 & 0.265 & 0.190 & 0.100 \\
\hline $\mathrm{PJN}$ & 40 & 0.041 & 0.029 & 0.092 & 0.205 & 0.146 & 0.173 & 0.111 & 0.126 & 0.172 & 0.159 & 0.144 & 0.100 \\
\hline PPN & 42 & 0.085 & 0.120 & 0.092 & 0.177 & 0.138 & 0.363 & 0.479 & 0.539 & 0.432 & 0.380 & 0.360 & 0.214 \\
\hline RIV & 43 & 0.463 & 0.290 & 0.246 & 0.222 & 0.437 & 0.621 & 0.675 & 0.776 & 0.876 & 0.882 & 0.869 & 0.737 \\
\hline RDW & 44 & 0.466 & 0.417 & 0.319 & 0.376 & 0.427 & 0.513 & 0.532 & 0.632 & 0.697 & 0.742 & 0.775 & 0.629 \\
\hline RFR & 45 & 0.087 & 0.068 & 0.109 & 0.375 & 0.230 & 0.437 & 0.398 & 0.344 & 0.293 & 0.328 & 0.335 & 0.273 \\
\hline $\mathrm{SCN}$ & 48 & 0.180 & 0.058 & 0.056 & 0.063 & 0.187 & 0.116 & 0.310 & 0.369 & 0.262 & 0.196 & 0.220 & 0.256 \\
\hline SEW & 49 & 0.023 & 0.083 & 0.347 & 0.667 & 0.300 & 0.083 & 0.055 & 0.109 & 0.120 & 0.097 & 0.066 & 0.032 \\
\hline
\end{tabular}


Table 6. LOOKUP table 2 (in control file), list of vegetation types with identifiers (Veg ID), density and growth parameters, and monthly $\mathrm{K}_{\mathrm{v}}$ values to calculate actual evapotranspiration for the California statewide calibration._-Continued

[WHR, wildlife habitat relationships; Veg ID, vegetation identification; LAI, relative leaf area index used for changing density for disturbance analysis; UpLimit, upperlimit; DnLimit, lower limit; UpRate, upper sensitivity; DnRate, lower sensitivity; x, facultative; —, non-facultative]

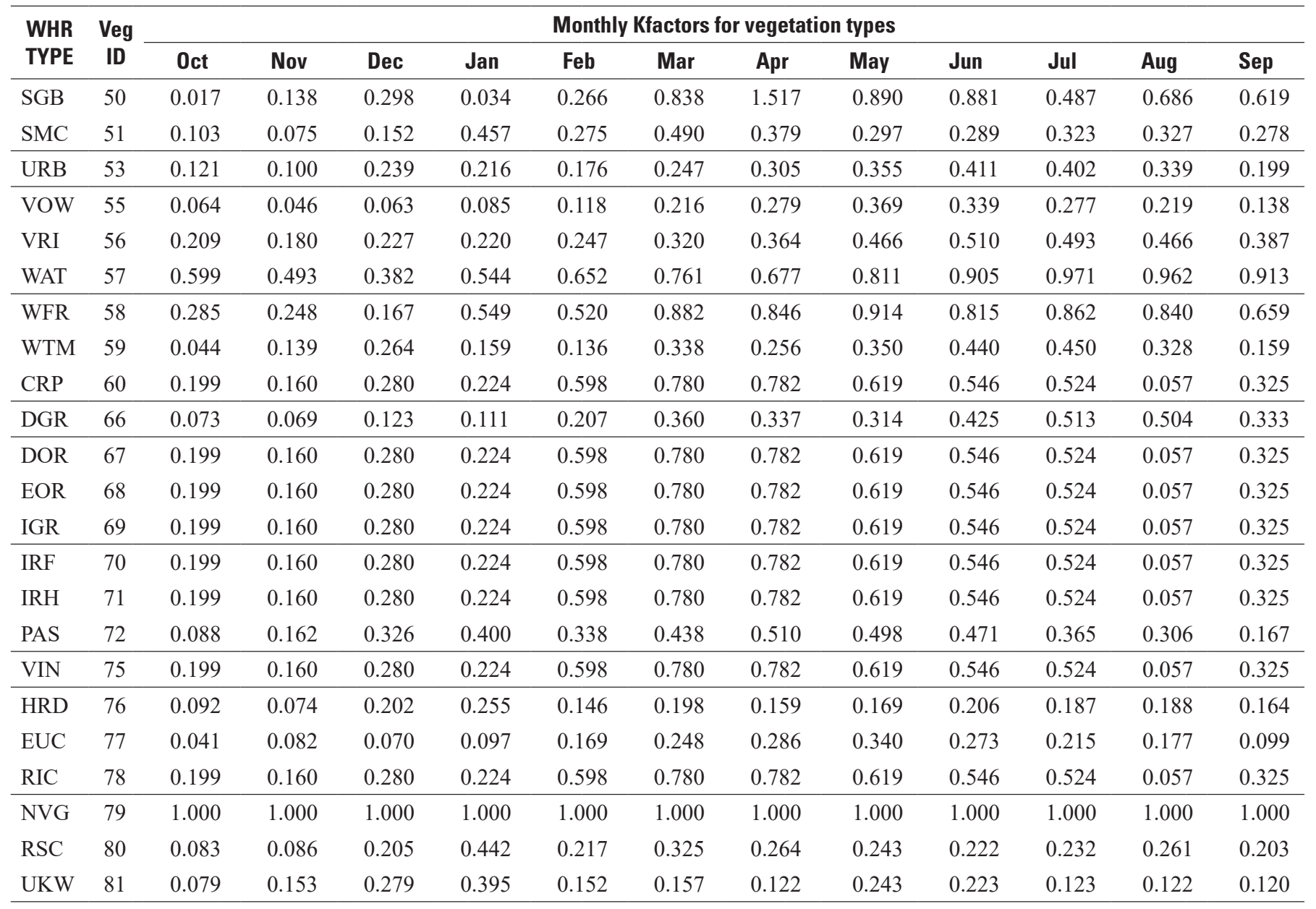

\section{Output Files}

Output files generated by BCMv8 simulations include gridded maps of output variables for snowfall (snw), snowmelt (mlt), snowpack (pck), sublimation (sub), excess water (exc), actual evapotranspiration (aet), soil-water storage (str), climatic water deficit (cwd), recharge ( $\mathrm{rch}$ ) and runoff (run; table 7), and monthly and water year output files (termed outfiles) that include time series for the period of the simulation with date, basin file name, basin ID table file name, all variables described in figure 5, as well as recharge and runoff calculated in acre-feet, smd_mm (soil-water deficit required to produce recharge), smr_mm (soil-water deficit required to produce runoff from overland flow), evap_mm (evaporation from soil), watbal_mm (water balance should equal 0 , to ensure that the model is calculating the water balance correctly), rchrunscaler (see section below for description), and Basin_area_m^2 (basin area; fig. 5).

\section{Software Options and the Control File}

Software options include running the model in calibration mode, where all " 1 "s are input into the first column of LOOKUP table 2. This ensures that changes are not imposed that do not represent natural or measured conditions. Disturbance mode is for various applications or sensitivity analyses, where a calibrated model has changes to vegetation imposed or application switches used.

The control file is shown in its entirety in appendix 1. Figure 6 provides an example of the control file with line numbers added (not to be included in actual control file) for discussion of files needed and optional operational switches used to turn processes or inputs on or off. 
Table 7. Input climate and output hydrologic variables for the BCMv8 with codes used in filenames and description of calculations.

$\left[{ }^{\circ} \mathrm{C}\right.$, degrees Celsius; mm, millimeter $]$

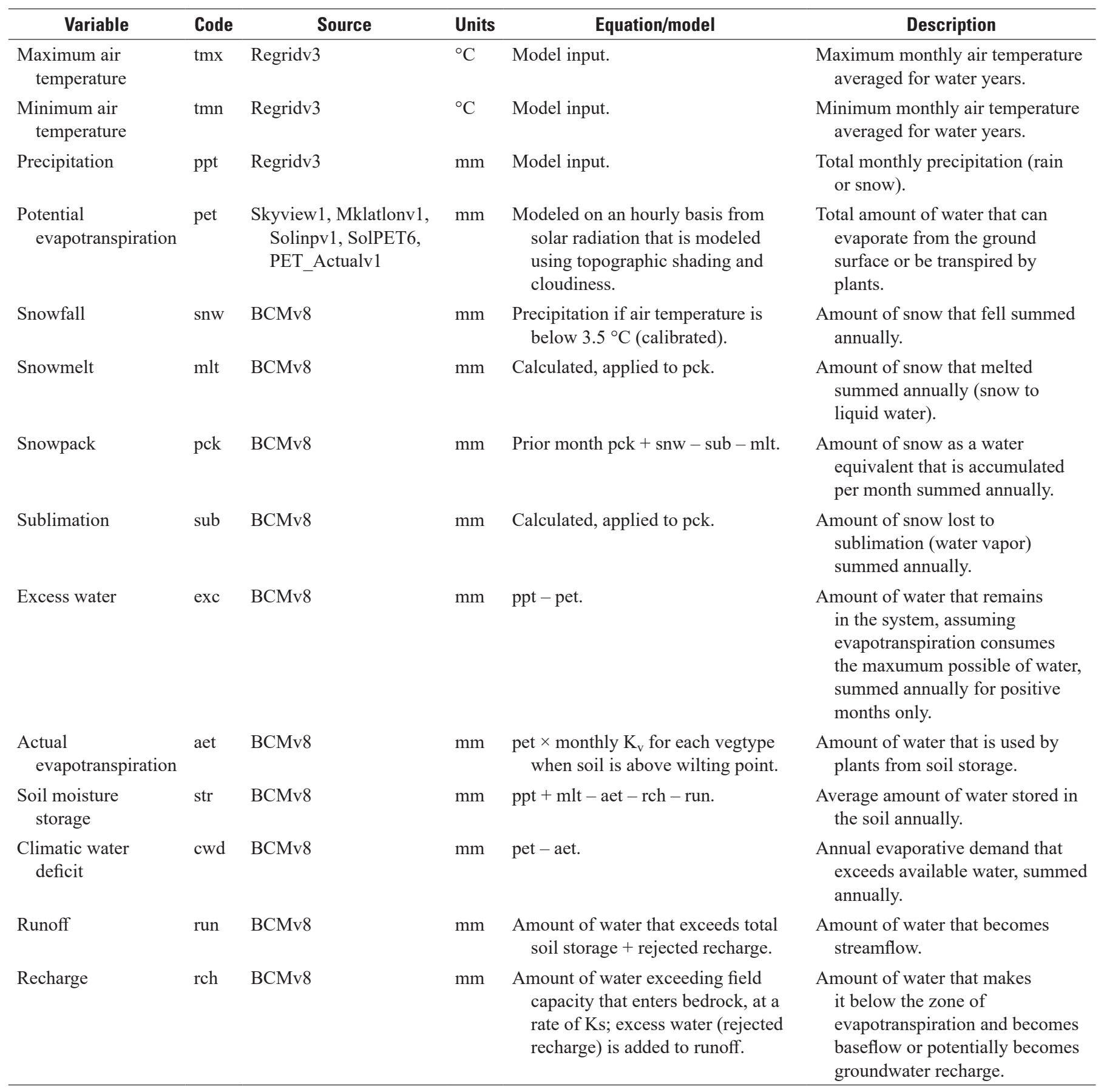




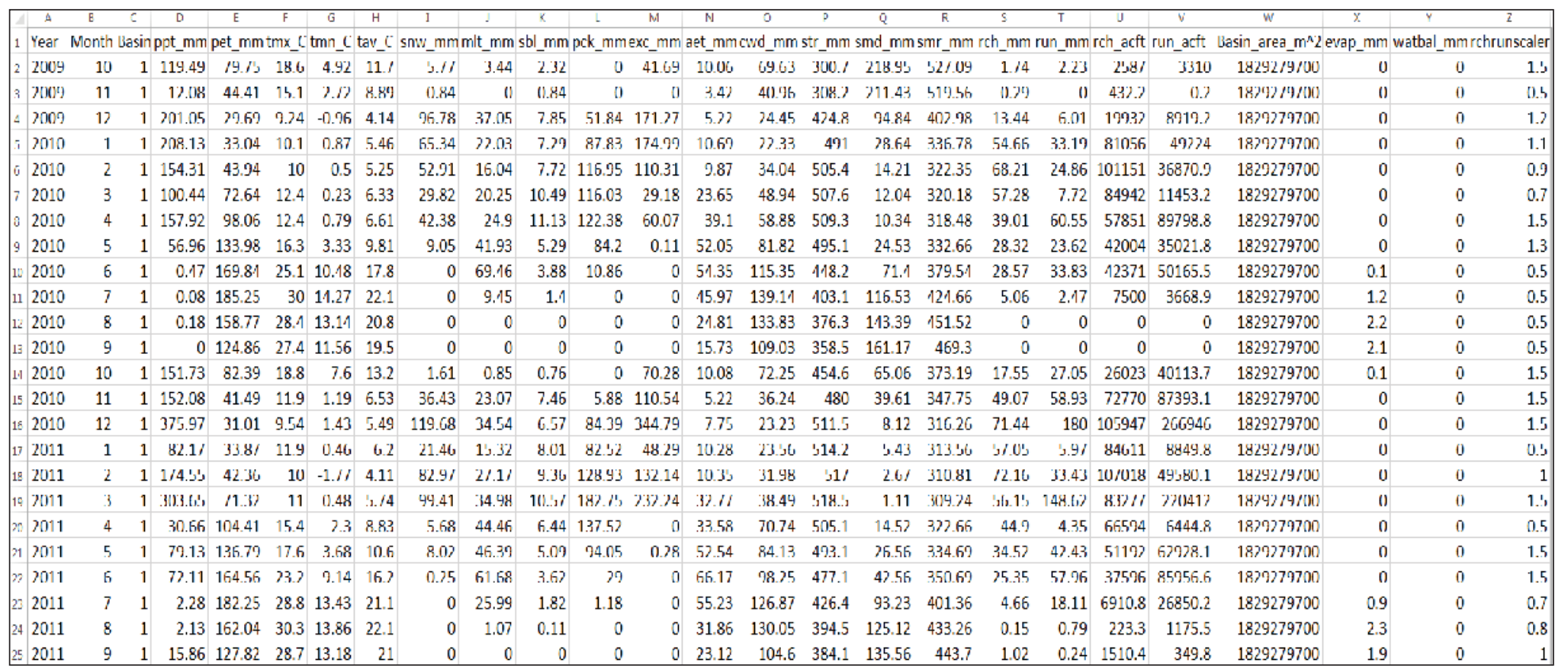

Figure 5. Example of simulation output file showing all input and output variables calculated monthly. 


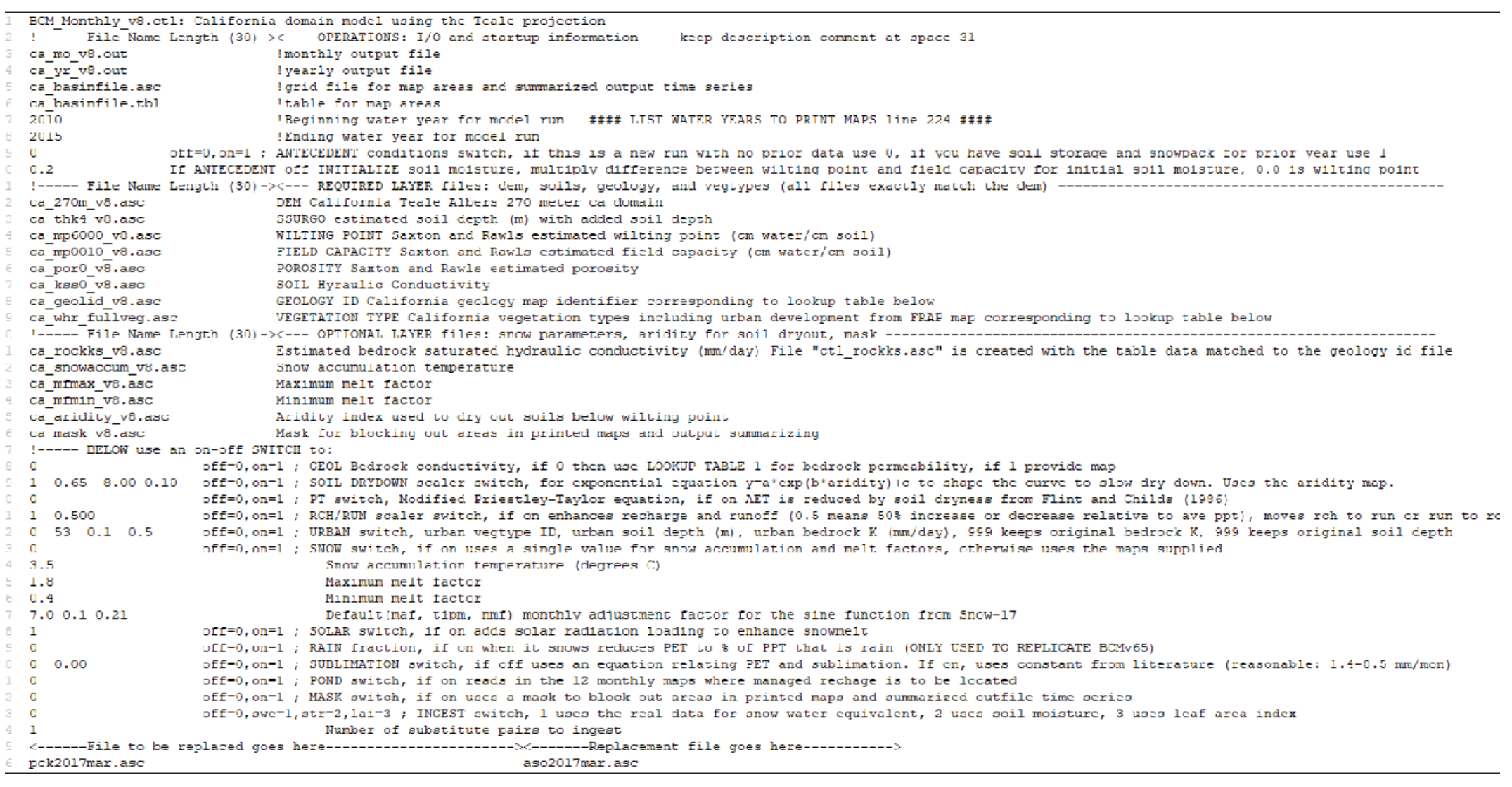

Figure 6. The BCMv8 control file with required and optional entries, not including LOOKUP tables for geology and vegetation. 


\section{Control File}

Required control-file entries include necessary file-name length (line 2), file names for monthly and yearly outfiles (lines 3 and 4), basin file-name and basin ID table file name (lines 5 and 6; these files allow for the summing or averaging of monthly and yearly output for areas with the same ID, for example, counties, basin areas upstream from a streamgage, plot points distributed by species, snow-sensor location), beginning and ending water years for model run (lines 7 and 8), initialization of soil-water content and ANTECEDENT conditions (lines 9 and 10), and layer files specific to model domain (lines 12-26).

Optional layer files include snow parameters (lines 22-24, used if SNOW switch is on, line 36), aridity (line 25, used if SOIL DRYDOWN switch is on, line 32), and mask (line 26, used if MASK switch is on, line 44). Additional switches are for reading the climate files from a directory that differs from the one in which the model is being run (switch line 30, directory identified in line 28); PT switch to use the Modified Priestley-Taylor equation (Flint and Childs, 1991) to reduce actual evapotranspiration from soils at a rate dependent on soil-water content (line 33); RCH/RUN scaler to enhance recharge or runoff in streamflow depending on average monthly precipitation to depict gaining and losing streams (line 34); URBAN switch to enhance runoff due to impervious surfaces (line 35); SOLAR to use solar-radiation loading to increase snowmelt (line 41); FLOOD to simulate flooded or ponded conditions (line 45); INGEST to replace modeled conditions (line 46) with real data (lines 49 and 50) for snow-water equivalent (swe), soil-water storage (str), or vegetation density (lai). Descriptions of these switches and others follow.

\section{Switch Descriptions and Examples}

All model simulations are run by water years, proceeding from October to September. Switches and control-file options are described in following paragraphs.

The ANTECEDENT conditions switch allows the user to use previously run model results (conditions at end of September of prior water year) as antecedent conditions to initialize a new model run. If there are no previous results, then INITIALIZE is used, which allows the user to put in a value between 0 and 1 that, when multiplied by the difference between soil-water content at wilting point and at field capacity for each grid cell, establishes the initial soil-water content.

The SOLAR switch allows the user to add solar-radiation loading to the snowmelt calculation to improve simulation of snowmelt variably across the landscape. The Snow-17 model for snowmelt is only based on air temperature, yet in topographically diverse regions such as the Sierra Nevada, solar-radiation increases snowmelt on south-facing slopes in comparison to north facing slopes, particularly in early spring when the sun is at a low angle. The SOLAR switch adds a temperature increase of 0.25 degree $\mathrm{C}\left({ }^{\circ} \mathrm{C}\right)$ for each 2.5 megajoule per day (MJ/day) that solar radiation exceeds $7.5 \mathrm{MJ} /$ day. (Filenames of average monthly solar radiation maps are included in model runs and in the control file for reference.) Snowmelt and snowpack are shown with and without the SOLAR switch for the upper Kern River basin in the southern Sierra Nevada in figure 7, indicating that with the switch on there is more snowmelt and less snowpack in spring when the sun is at a lower angle, yet air temperatures are still low, and less snowmelt in the summer when radiation is more evenly distributed across the landscape. Cool colors in the map indicate less melt with switch on, and warm colors indicate a larger impact of solar radiation on snowmelt, as exemplified by south facing slopes.

The PT switch enables the user to use the Priestley-Taylor actual evapotranspiration equation that reduces AET on the basis of soil dryness by modifying $\alpha^{\prime}$ (Flint and Childs, 1991, equation 5, fig. 4). In this case, $\alpha^{\prime}$ has been modified as follows:

$$
\alpha^{\prime}=1-e^{(-9.74 \times \text { soil water content })}
$$

This switch slows soil drying differently for various soils and climates, increasing AET, and is illustrated in figure 8 for the Merced-Tuolumne basin, averaging AET and soil-water storage monthly for basins 5,2 , and 3 . With lower AET, more soil water is carried over to the following month.

The RCH/RUN scaler switch is used to simulate gaining and losing streams by increasing recharge relative to runoff if monthly precipitation is less than the long-term monthly average precipitation and by increasing runoff relative to recharge if the monthly precipitation is higher than the long-term monthly average precipitation. This switch is used when the user wants to improve the accuracy of recharge and runoff maps as they relate to streamflow estimates. Conceptually, the scaler works by calculating if recharge is more or less likely to become base flow or runoff is more or less likely to become lost to the unsaturated zone, because of variations in precipitation. If the switch is on, the user sets a multiplier between 0 and 1 that moves water from recharge to runoff or from runoff to recharge depending on the monthly precipitation relative to its long-term average. A value of 0.5 moves 50 percent of recharge to runoff if precipitation is higher than average, whereas a value of 0.2 moves 20 percent of recharge to runoff if precipitation is higher than average. This is illustrated in figure 9 for the upper Mad River as change in RCH and RUN for multipliers of 0.2 and 0.5 , respectively, in comparison to RCH and RUN with the switch off for water years 2009-15. For this example basin, the long-term average monthly precipitation was 183 millimeters $(\mathrm{mm})$. In wetter months, RUN is increased and RCH is decreased, simulating increases in base flow. For periods with less than average precipitation, there is much less recharge and runoff, but RCH is increased, and RUN is decreased, simulating streamflow seepage losses. 
A

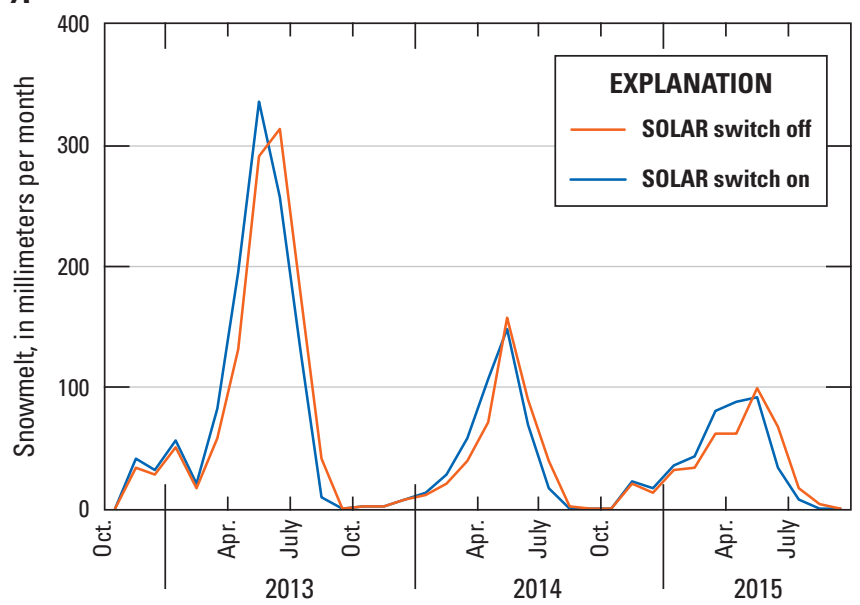

B

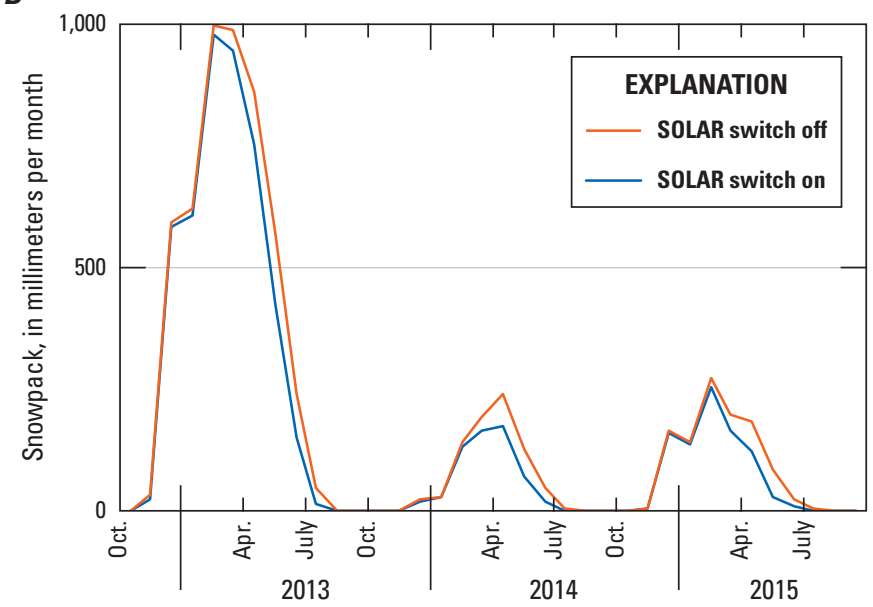

C

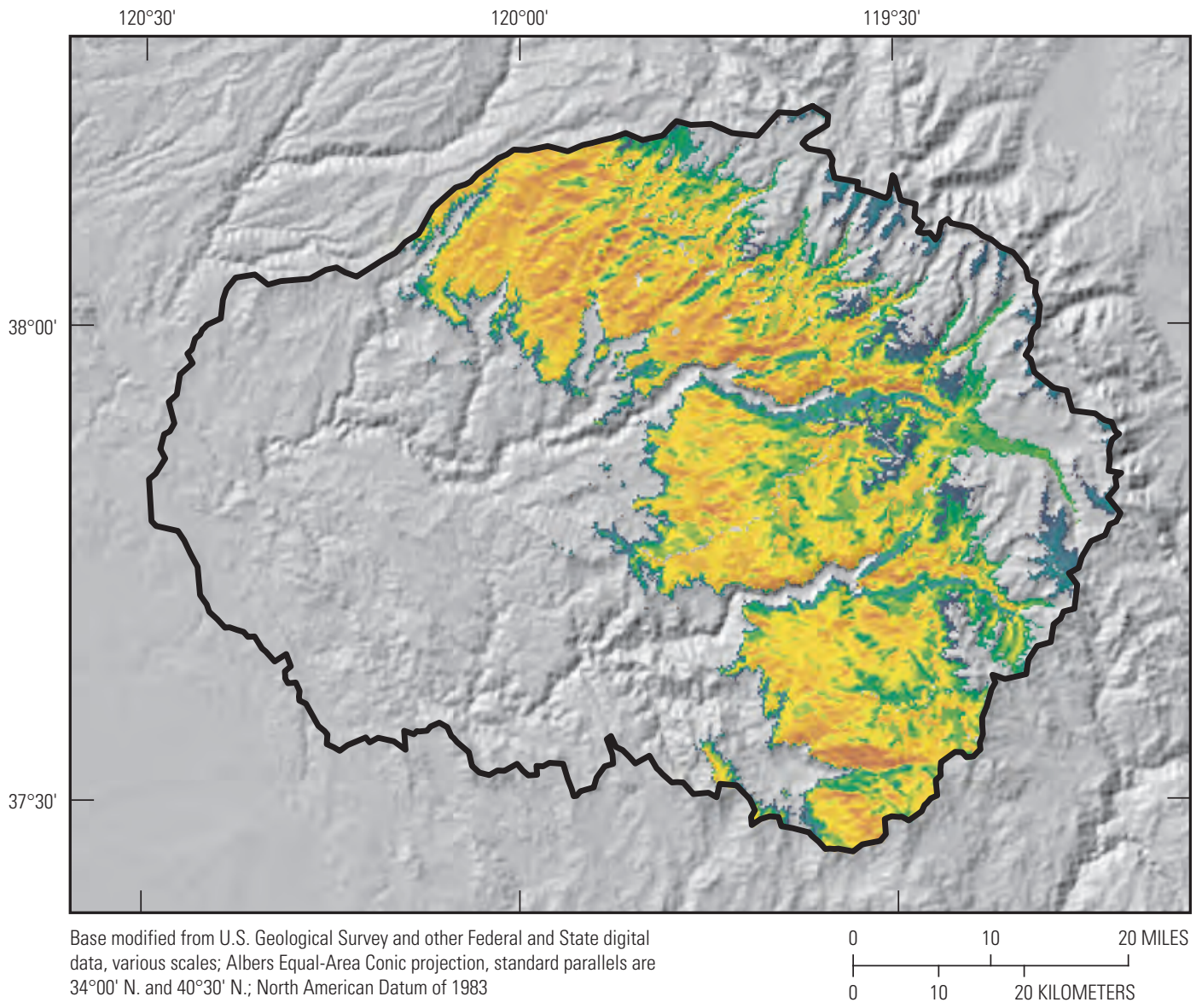

EXPLANATION

Snow water equivalent (difference), in millimeters

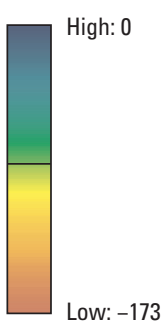

Note: positive is less snow water equivalent and negative is more snow water equivalent when switch is on

Figure 7. Simulation results from model runs with the SOLAR switch on and off for the upper Merced River basin for $A$, snowmelt for water years (WY) 2012-15; B, snowpack for WY2012-15; and C, difference in snow-water equivalent for Apr 1, 2011. 

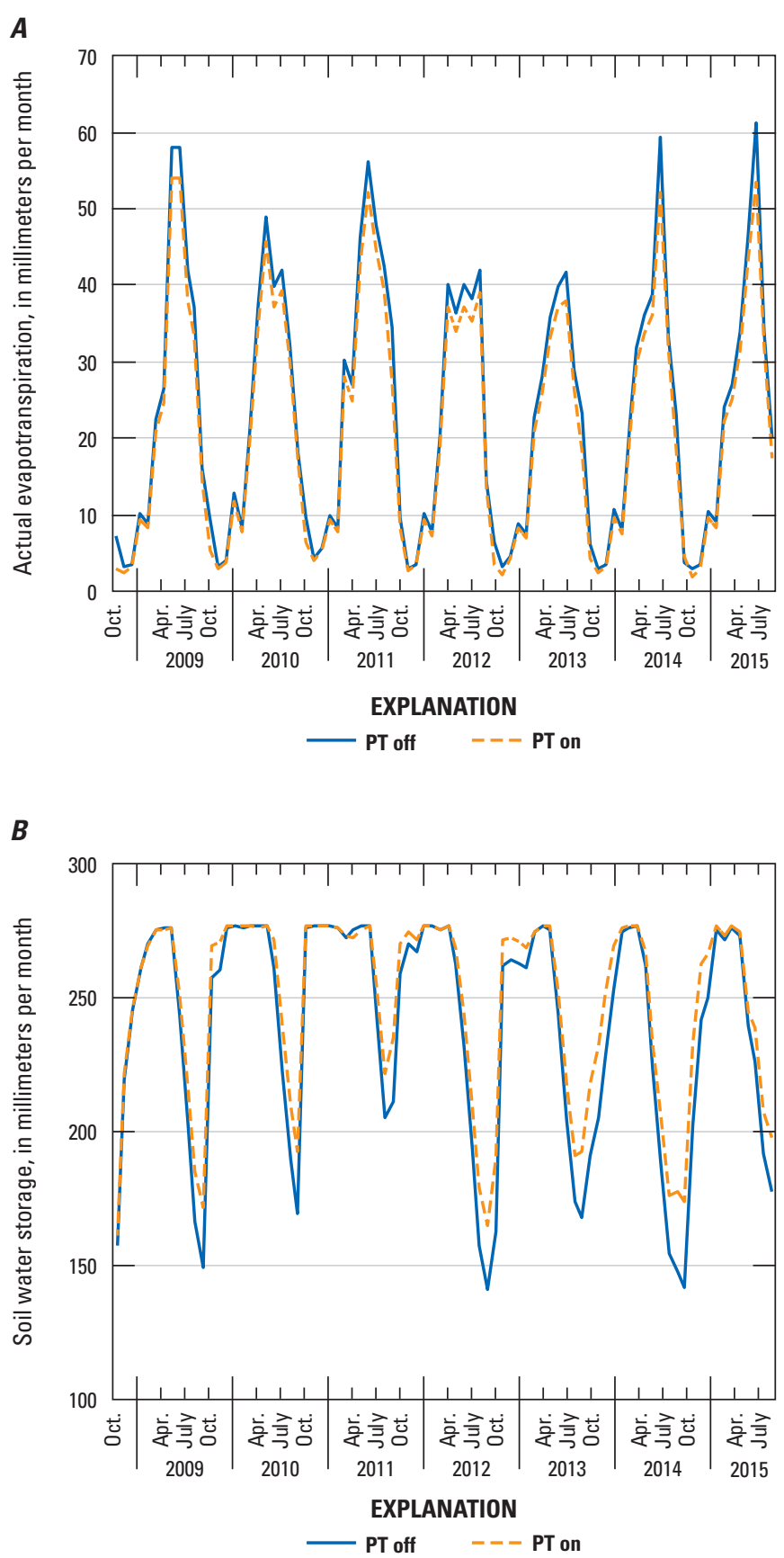

Figure 8. Effects on simulation results for the Merced-Tuolumne basin, 2008-14, of the Priestley-Taylor (PT) switch, which when "on" simulates $A$, less actual evapotranspiration (AET) and $B$, more soil-water content.
The RAIN fraction switch reduces PET for every month with any snowfall to the percentage of precipitation that is rain. This switch is only used to replicate results from the BCMv65.

The SUBLIMATION switch allows the user to use a constant from the literature for sublimation (reasonable range of values is $1.4-8.5 \mathrm{~mm} /$ month). The default is based on an internal model equation that was developed by Reba and others (2011) using data from a site in Idaho.

The remaining switches, if used, require optional maps.

The GEOL switch requires the input of a user-developed rockks map that provides the bedrock conductivity in map format rather than as in LOOKUP table 1, which relies on the geologic ID from map geolid.asc. This switch provides the option to use measured conductivities or zones that differ from those in the available geology map.

The SOIL DRYDOWN scaler dries out soil if the soil water content is less than the wilting point as a result of drought conditions at a rate that correlates to the aridity map, following this equation:

$$
y=a \times e^{(b \times a r i d i t y)}+c
$$

Default values for this equation are $a=0.65, b=-10.00$, and $\mathrm{c}=0.05$, but these can be changed to shape the curve to slow dry down. These values were used to calibrate the model to match soil-water content at a site in northern California during the 2012-14 drought (fig. 10). The measured inflection point in the summer of water year 2012 shows when the plants stopped using soil water at wilting point ( $\sim-3 \mathrm{MPa})$, and the soil drying continued as a result of evaporation from the soil surface.

The URBAN switch allows the user to impose a set of properties to simulate urban levels of imperviousness, which results in increased runoff and reduced recharge where urban-land cover is shown in the vegetation map. In this case, if the switch is set to " 1 ," the user can identify the urban ID number from the vegetation map (in this case 53) and set the soil depth (in this case 0.1 ) and the underlying bedrock conductivity (in this case 0.5 ). If the original soil depth or bedrock conductivity (GeolK) is desired, 999 in place of either the soil depth value or GeolK value maintains the original soil depth value from the soil thickness map, or the GeolK value from LOOKUP table 1. 


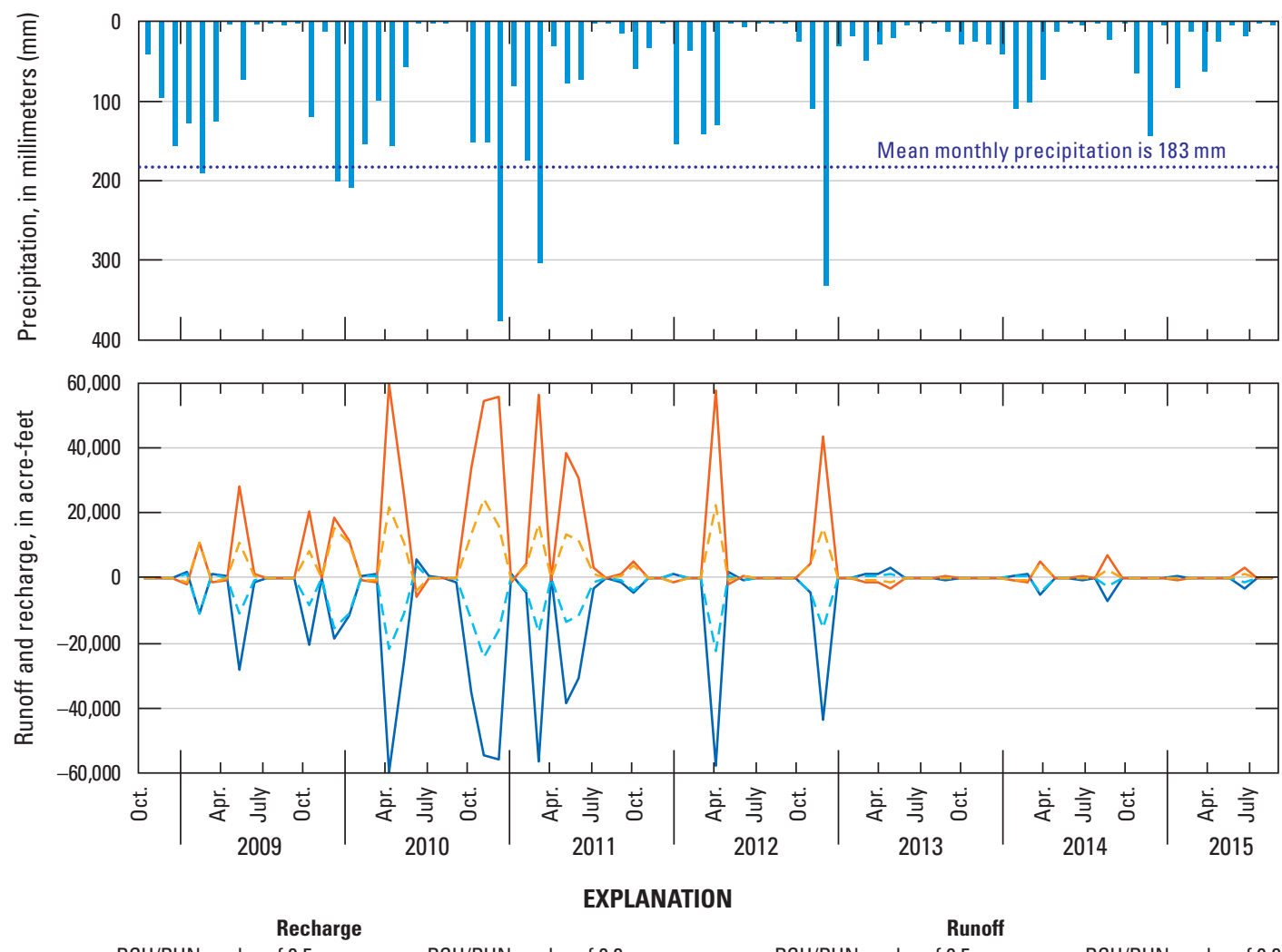

Figure 9. The effects of using the $\mathrm{RCH} / \mathrm{RUN}$ scaler in a simulation of the upper Mad River for a range of annual precipitation values on recharge and runoff for water years 2009-15 for two scalers, 0.5 and 0.2 .

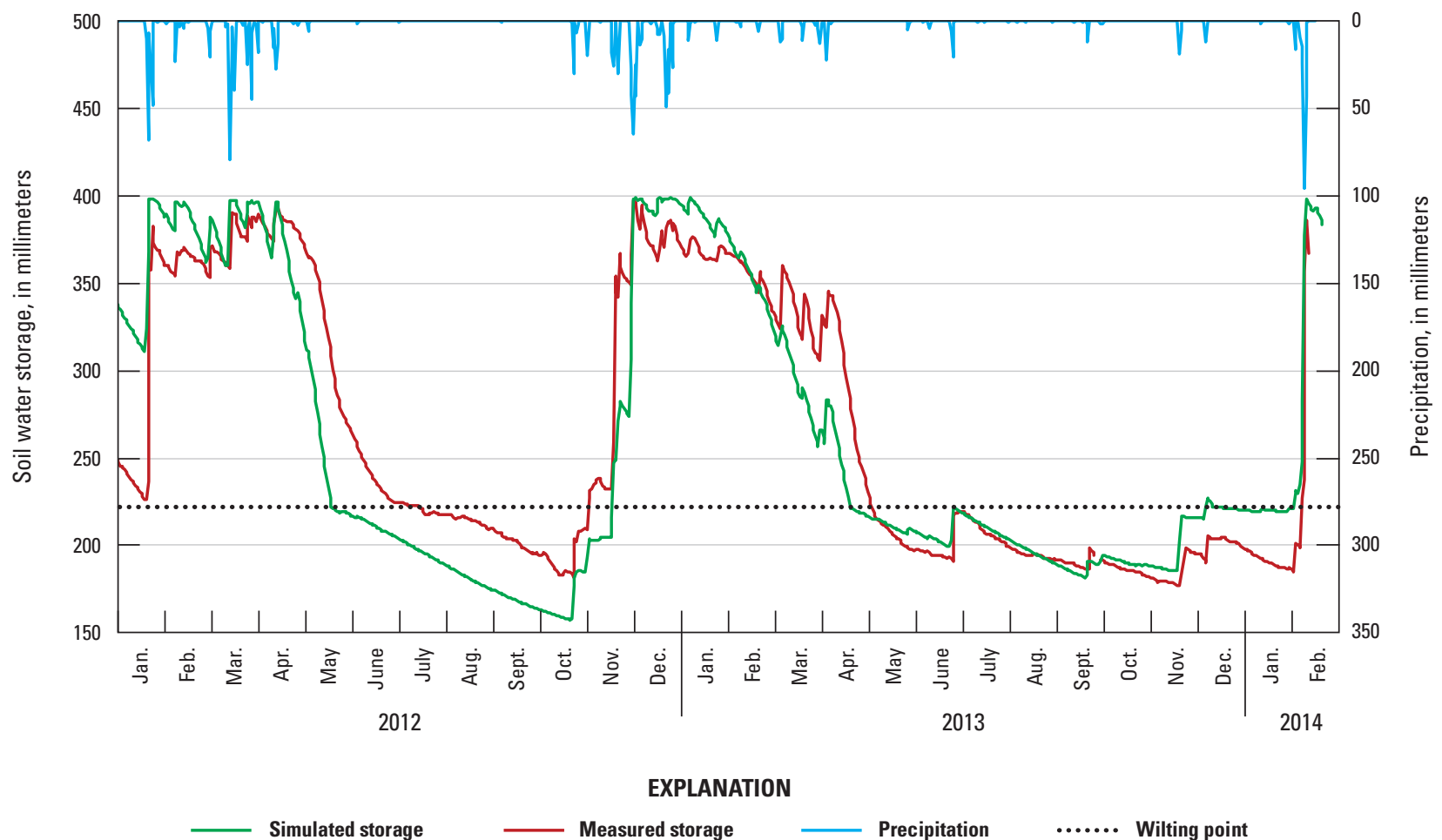

Figure 10. Precipitation and simulated soil-water content and measured soil-water content at a grassland site in northern California. 
The SNOW switch provides the user the opportunity to develop a site-specific snow calibration by using the snow-accumulation temperature and maximum and minimum melt factors, which are explained in detail in Anderson (2006). By default, values for North America are used for monthly adjustment parameters (maf, monthly adjustment factor; tipm, antecedent temperature index parameter; and $\mathrm{nmf}$, negative melt factor). If this option is not active, the optional layer files snowaccum.asc, mfmax.asc and mfmin.asc are used. These maps were developed using data from 120 snow courses and smoothed to develop spatially distributed snow accumulation and melt factors. Detailed instructions for the development of these maps are in appendix 2.

The FLOOD switch allows the user to use 12 monthly maps that identify where in the study area flooding would be used to simulate flooded conditions, such as managed wetlands for habitat, or locations where managed aquifer recharge is desired. If the switch is on, the BCMv8 reads the 12 monthly maps with filenames in lines 204-215. If flooding is desired, the cell value needs to be " 1 "; if not, then the cell value should be noData (-9999). In cells with a "1," soil storage for that month is equal to porosity; recharge is calculated as the hydraulic conductivity of the soil (Ksat) or bedrock GeolK, whichever is less; and runoff is calculated as precipitation greater than porosity. Depth of ponded water is not considered, and calculations of recharge assume a unit gradient. Maps can be identical for any or all months or can differ by locations of flooding each month; however, the set of monthly maps is repeated as input for subsequent years.

The MASK switch allows the user to mask areas that are not to be included in the summarizing of all variables in the monthly and yearly outfiles.

The INGEST switch provides the user an opportunity to incorporate measured data into a model run for snow-water equivalent (SWE), soil-water storage (STR), or vegetation density as a relative leaf area index (LAI). In this switch, the user uses 1 to ingest SWE data, 2 to use soil-water data, or 3 to ingest a new LAI map (see application 3). The number of months that is to be ingested is indicated, and the file names that are to be replaced are noted with the file name for the ingested file directly following it. If, for example, 2 months are intended for ingestion, the control file would look as it does in figure 11. These ingested files then need to be included in the input files.

\section{Developing a New BCMv8}

A BCMv8 model can be developed for new areas or extracted from existing models that have been developed at 270-m resolution. If the area is outside California or other locations where $\mathrm{BCM}$ datasets are available (Great Basin, Upper and Lower Colorado River Basins), and a new model is to be created from scratch, there are several things to consider during the initial development.

Development of a new model can be done for a point in space, a watershed, or an entire region. Determination of model extent and grid size may depend on data availability, computing power, and application. Depending on data availability, climate can be obtained from existing gridded data or station data. Model extent should include all land areas that drain to the area of interest, as indicated by elevational and topographical gradients. A new model requires the development of all climate layers, including PET, which is then calibrated to cloudy sky conditions using station data for reference ET. All soils data and geology are developed into input layers, as well as vegetation. The sequence of steps used to develop various grids are described in detail in appendix 2 .

To ensure data availability for hydrologic calibration, a model domain with boundaries that include areas upstream from streamgages that are relatively unimpaired or with data available for management activities (diversions, augmentation, and so on) should be selected. A basin file should be developed (see appendix 2, fig. 2.1) that defines areas that drain to streamgages and may include points for other calibration data such as snow sensors. The climate data included in the extraction should include the period of record of available calibration data. A post-processing spreadsheet is used to compare the $\mathrm{BCMv} 8$ recharge and runoff output to measured streamflow data as a means of calibrating the model or evaluating changes in streamflow as a result of scenario testing (see Example Applications section).

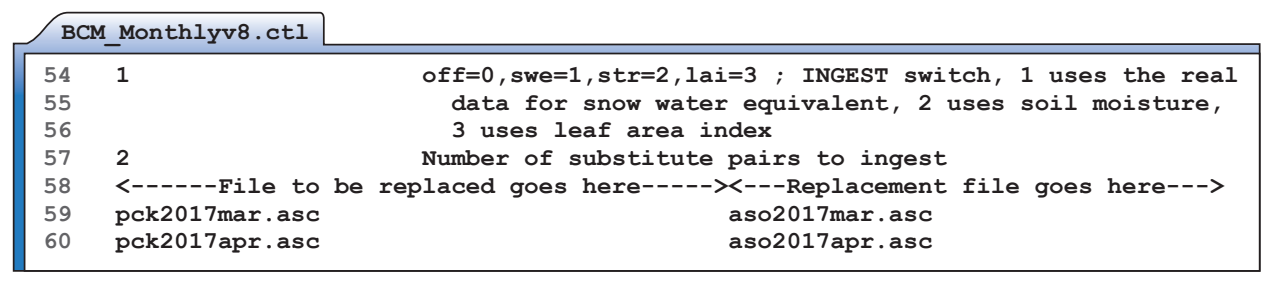

Figure 11. Convention for using INGEST to replace files with 2 months of measured data. 
Calibration is done by adjusting a range of different parameters and files. Soil properties can be changed by using different WILTING POINT and FIELD CAPACITY maps; snow parameters can be changed to match local snow data; bedrock conductivity can be adjusted to vary the relative proportions of recharge and runoff; AET parameters can be adjusted to change the amount of water that is lost to AET and therefore increase or decrease the total recharge and runoff; and switches can be toggled on or off to enhance soil drying, add urban surfaces, or include measured snow or soils data. Manipulation of the CalBasin spreadsheet helps to inform calibration choices. This spreadsheet template is available with download of model files from https://ca.water.usgs.gov/ projects/reg_hydro/basin-characterization-model.html.

\section{Development of Basin File}

To facilitate calibration to streamflow data or vegetation-specific actual evapotranspiration, a basin file needs to be developed that is used in the control file and read by the model to accumulate or average all values of a variable for cells having the same basin identifier. In the case of basin areas upstream from streamgages, for example, basins are delineated beginning with watershed boundaries (fig. 12A) aggregated or adjusted to represent areas upstream from streamgages or reservoirs (fig. 12B). A unique identifier is assigned for each basin. The ArcGIS shapefile is then converted to a raster on the basis of the identifier then converted to an ASCII file to exactly match the file dimensions of the DEM (fig. 12C, 12E). A table file (*.tbl) is developed in a text software that has an integer identifier for each basin and a corresponding basin name (fig. 12D, 12F). Additional points can be added to include other field observations, such as snow-water equivalent measured at snow sensors or soil-water content, in order to output additional calibration time series. If a vegetation map is used as a basin file, then the AET is output for all cells for each vegetation type in order to calibrate the model to measured AET.

If the user requires only gridded-map outputs or one number for the entire study area, a basin file that has a constant value spanning the entire DEM is required input. Such a file can be created from an ArcGIS shape file by using the "Feature to Raster" tool in the Conversion Tools/To Raster toolbox in ArcGIS. Alternatively, this format conversion can be done using R or Python computing environments. It is important to list the unique identifier for the basins or other subdivisions and identify or name each one in the table file to keep track of results. If there are any "noData" gridcells in the basin file, there will be no data printed out in the output maps.

\section{Calibration of Actual Evapotranspiration}

Following the development of input files for a local calibration, the first process in calibration is to develop vegetation parameters that allow the user to match the calculated AET either to field observations or estimates that have been developed using remotely sensed observations (ETa; Reitz and others, 2017; fig. 13). This figure illustrates the relative insensitivity of Redwood to annual variations in precipitation, whereas Blue oak woodland is very sensitive to variations in precipitation.

The relative leaf area index (LAI) under equilibrium conditions, can be thought of as a vegetation density parameter. It is set to 1 for calibration purposes. To calibrate the model, first, clip the monthly ETa files to the local basin boundary. Dividing the ETa by PET for each month and extracting by vegetation type provides $\mathrm{K}_{\mathrm{v}}$ that are averaged over the period of ETa observations (here using water years 2000-15) and input into LOOKUP table 2 (table 6). In order to calculate AET, the model reads the control file and multiplies the $\mathrm{K}_{\mathrm{v}}$ by the PET for each month for each vegetation type, unless soil-water content reaches the wilting point.

Next, run the model to adjust the RootDepth parameter, if necessary, to increase the average AET for the period to match the ETa time series for each vegetation type. This parameter increases the effective soil depth (in meters) relative to the mapped soil depth for each vegetation type. Examples of the statewide calibration showing increases in RootDepth for all vegetation types are provided in LOOKUP table 2 (table 6 and appendix 1).

The sensitivity of vegetation type to annual changes in precipitation is the next step (see fig. 13 and table 6), and it is adjusted using the growth factors UpLimit, DnLimit, UpRate, and DnRate. The upper and lower limits assign how high and how low the maximum AET can be each water year, whereas the up and down rates define how quickly the vegetation type responds to precipitation each month. In BCMv8's calibration mode, when LAI is equal to 1 (non-disturbance conditions), the precipitation for each month is compared to the long-term (here, 1981-2010) average monthly precipitation, and a scaler is calculated that is multiplied by the $\mathrm{K}_{\mathrm{v}}$ for that month. If the month has above-average precipitation, the scaler increases the $\mathrm{K}_{\mathrm{v}}$ at a rate defined by the UpRate; if precipitation is less than average, the $\mathrm{K}_{\mathrm{v}}$ is decreased by the scaler at a rate defined by the DnRate, making the AET more or less sensitive to differences in precipitation. 
$\boldsymbol{A}$

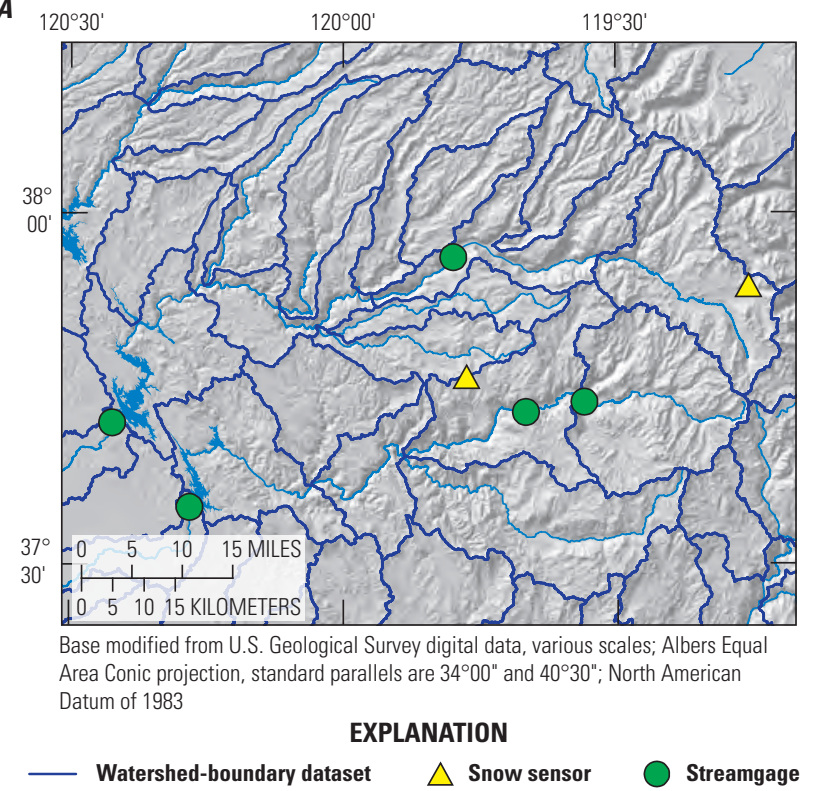

B

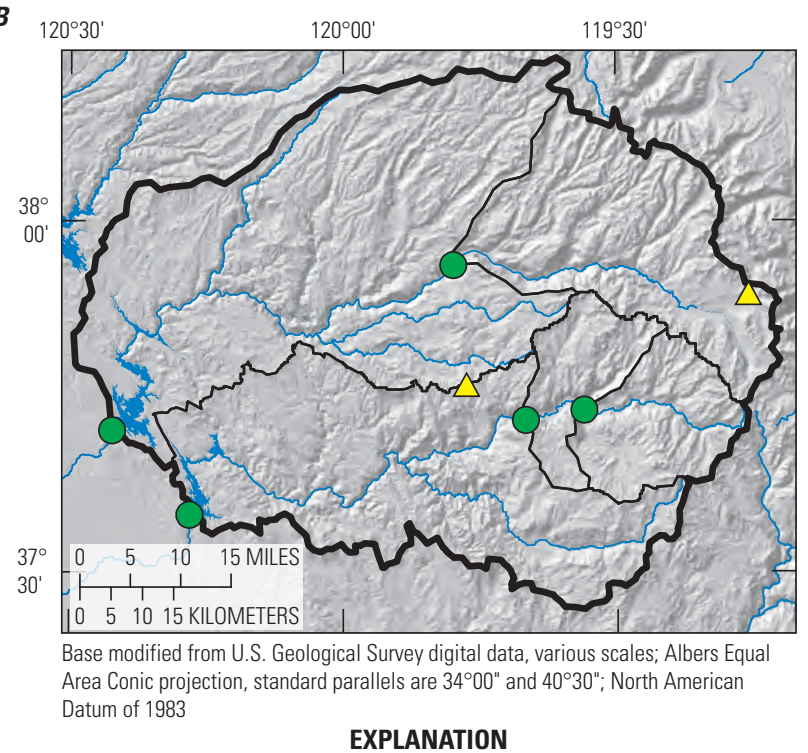

— MT_basins — MT_domain $\triangle$ Snow sensor

Streamgage

c

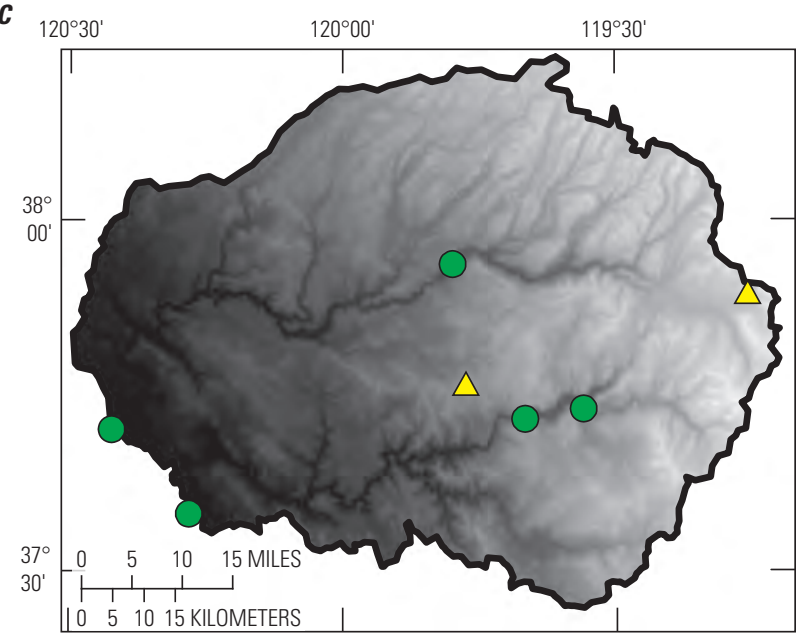

Base modified from U.S. Geological Survey digital data, various scales; Albers Equal Area Conic projection, standard parallels are $34^{\circ} 00^{\prime \prime}$ and $40^{\circ} 30^{\prime \prime}$; North American Datum of 1983

EXPLANATION

$\begin{array}{lll}\text { Digital elevation model (DEM) } & \triangle \text { Snow sensor } \\ \text { MT_domain } & \bigcirc \text { Streamgage }\end{array}$

$E$

\begin{tabular}{|c|c|c|}
\hline \multicolumn{2}{|c|}{ mt_270m_t3.asc } & \\
\hline & ncols & 429 \\
\hline & nrows & 337 \\
\hline 3 & xllcorner & -43231.995813 \\
\hline 4 & yllcorner & -65968.177246 \\
\hline 5 & cellsize & 270.000000 \\
\hline 6 & NODATA_value & -9999.0 \\
\hline
\end{tabular}

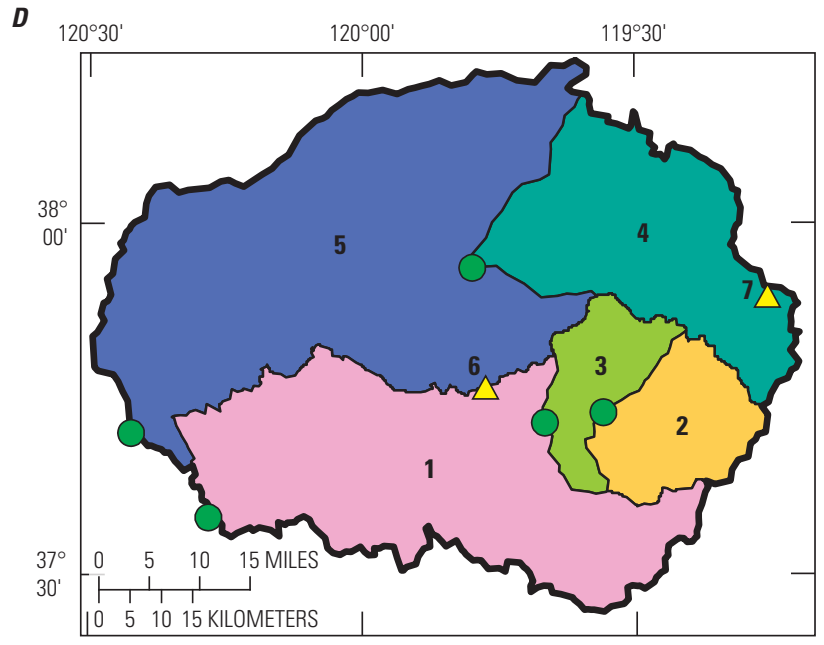

Base modified from U.S. Geological Survey digital data, various scales; Albers Equal Area Conic projection, standard parallels are $34^{\circ} 00^{\prime \prime}$ and $40^{\circ} 30^{\prime \prime}$; North American Datum of 1983

\section{EXPLANATION}

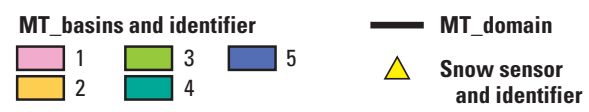

$\boldsymbol{F}$

\begin{tabular}{|l|}
\hline \begin{tabular}{|lll|}
\hline 1 & MT_basins.tbl \\
2 & Site & Basin Name \\
3 & 1 & Merced above Exchequer \\
4 & 2 & Happy Isles \\
5 & 3 & Pohono \\
6 & 4 & Tuolumne Grand Canyon \\
7 & 5 & Tuolumne above Don Pedro \\
8 & 6 & Gin Flat snow sensor \\
9 & 7 & Dana Meadows snow sensor \\
\hline
\end{tabular} \\
\hline
\end{tabular}

Figure 12. The steps to develop a basin file for five basins, upstream from streamgages and two snow sensors, indicated over a shaded relief map of the Merced-Tuolumne basin (MT_domain): $A$, step 1: begin with GIS shapefile of watersheds; $B$, step 2: aggregate watersheds in areas upstream from streamgages; $C$, step 3: clip digital elevation model (DEM) to outer boundary; $D$, step 4: convert shapefile to raster file, then to ASCII file; $E$, ensure basin file header exactly matches the DEM header; and $F$, step 5 : create a table file that identifies the new basins. 
$\boldsymbol{A}$

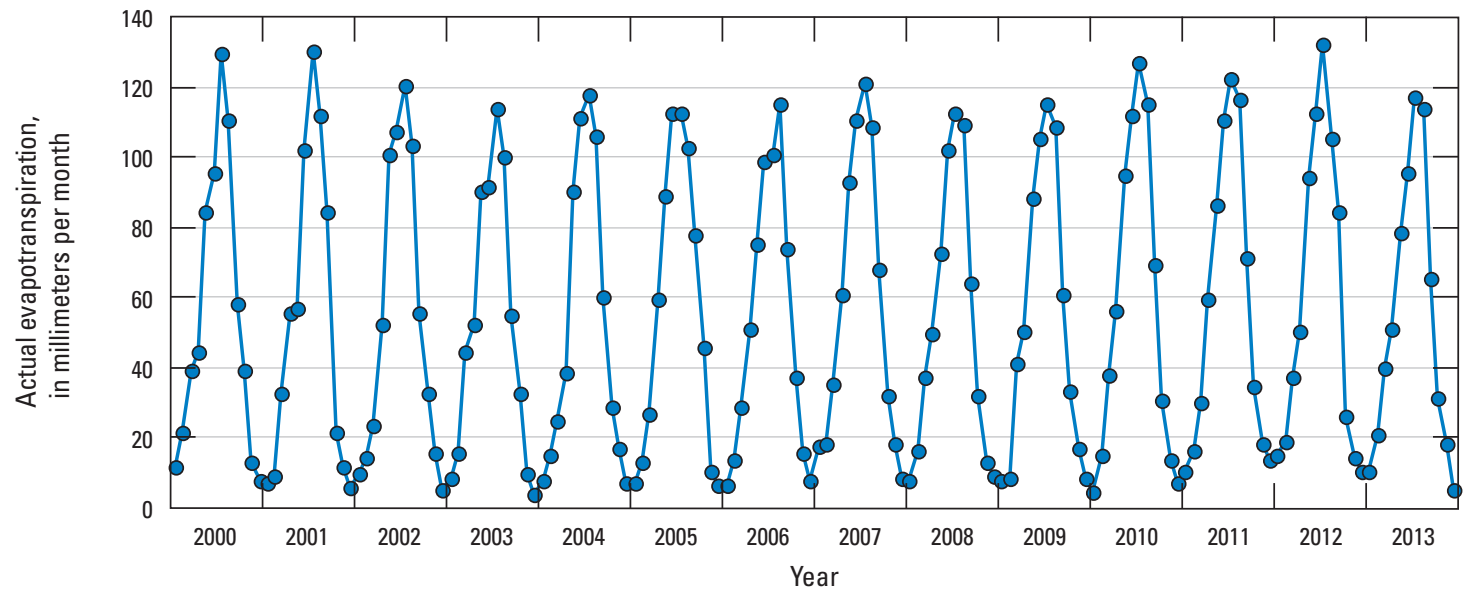

B

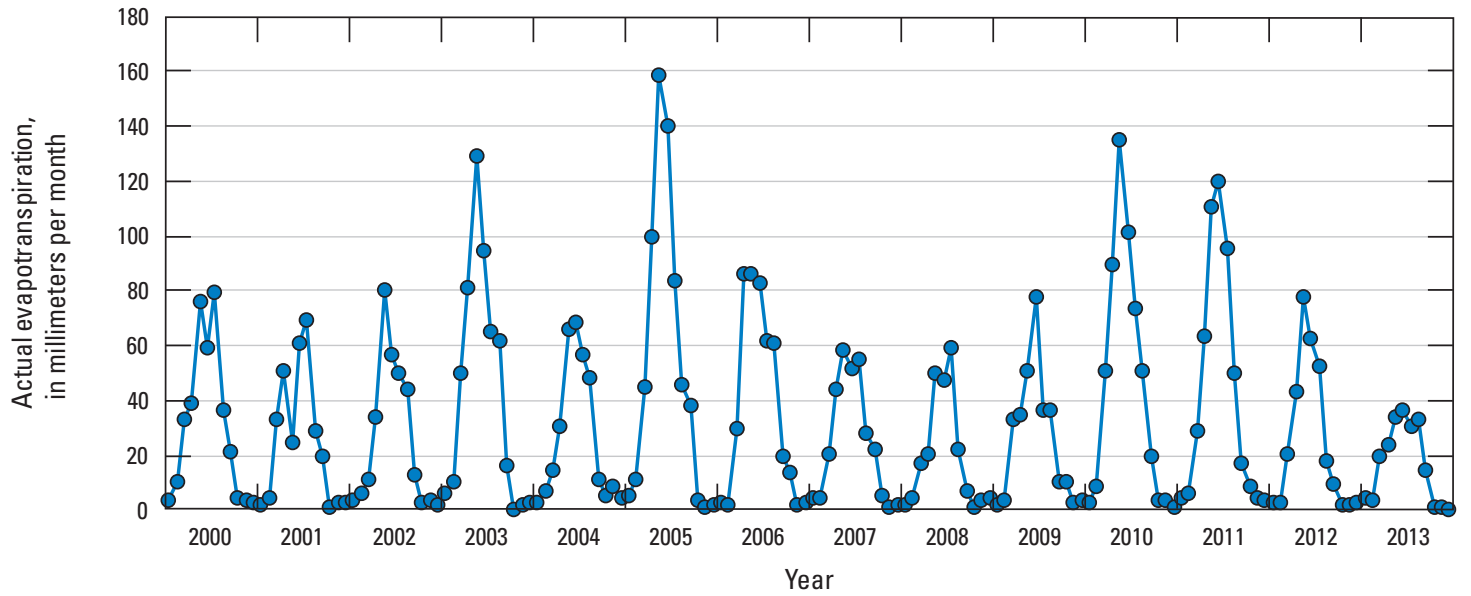

Figure 13. Monthly actual evapotranspiration from Reitz and others (2017) illustrating varying sensitivity to annual variability in precipitation by different vegetation types (table 6): $A$, redwood (RDW, type 44) and $B$, blue oak woodland (BOW, type 9).

Disturbances can be included in scenario testing to reduce the vegetation and corresponding AET by a simple multiplier indicated by the LAI parameter. See applications 2 and 3 for examples of simulated disturbance. If the LAI is less than 1, the model uses BCMv8's disturbance mode to calculate the precipitation scaler as the monthly precipitation divided by the long-term average monthly precipitation (rather than the average annual precipitation when in calibration mode). This number is calculated for each month and is multiplied by the monthly $\mathrm{K}_{\mathrm{v}}$. If disturbed, regrowth or recovery of vegetation can be manipulated in accordance with field observations to test hydrologic effects. The values and sensitivity of the density and growth factors are illustrated using Douglas fir (vegID=14) in the upper Mad River (fig. 14) by figures 15, 16, and 17. After a disturbance to a vegetation type (LAI is less than 1.0), LAI continues to increase, even if the precipitation is below average, until the DnLimit is reached. The UpRate determines how quickly vegetation grows back from a disturbance at a rate controlled by the amount of precipitation for that month (fig. 16). For example, in June (dry season), the LAI grows back more slowly than in December (wet season), because the UpRate is multiplied by the ratio of monthly precipitation to the total annual precipitation. The DnRate reduces LAI at a rate determined by the parameter and the precipitation scaler until the DnLimit is reached (fig. 17). Table 6 provides the default values of the vegetation parameters and table 8 provides the range of reasonable values for disturbed conditions for each parameter. 


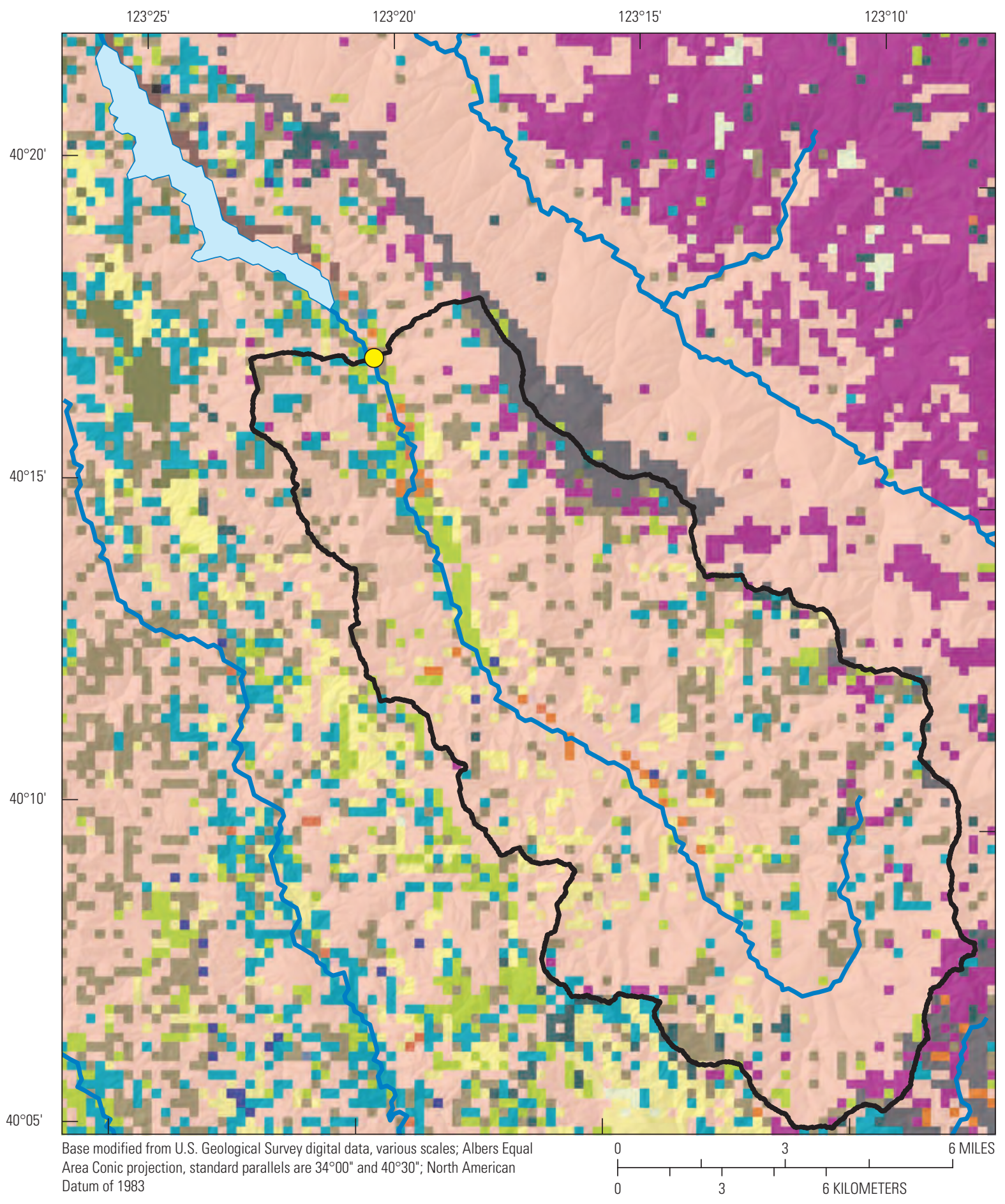

EXPLANATION
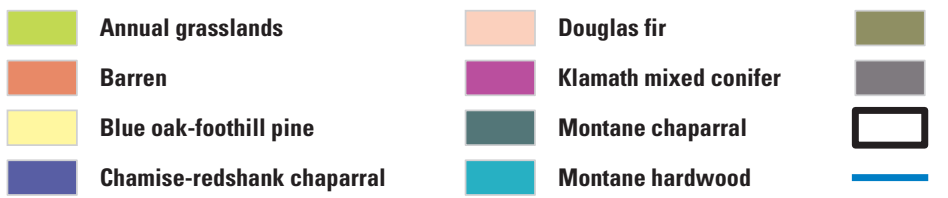

Perennial grassland

Streamgage

White fir

Upper Mad River subbasin

Mad River

Figure 14. Spatial distribution of vegetation types in the Upper Mad River subbasin where Douglas fir is predominant and used to test disturbance effects on actual evapotranspiration (AET). 
$\boldsymbol{A}$

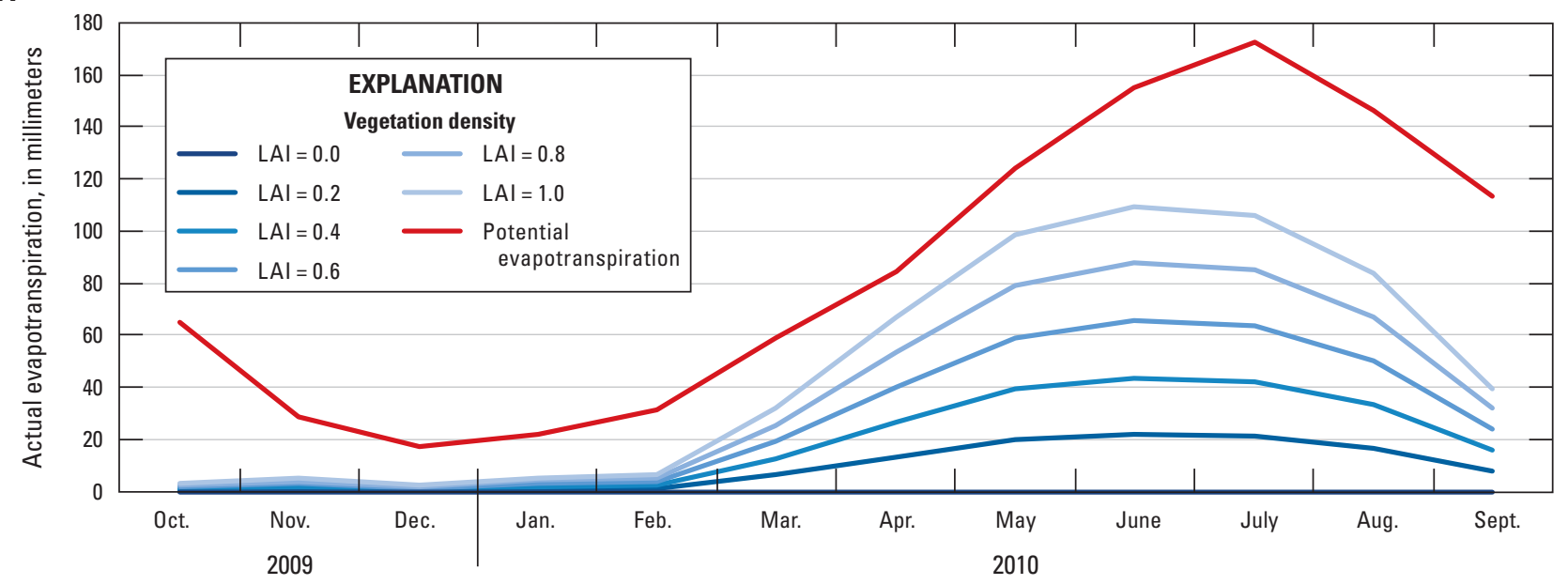

B

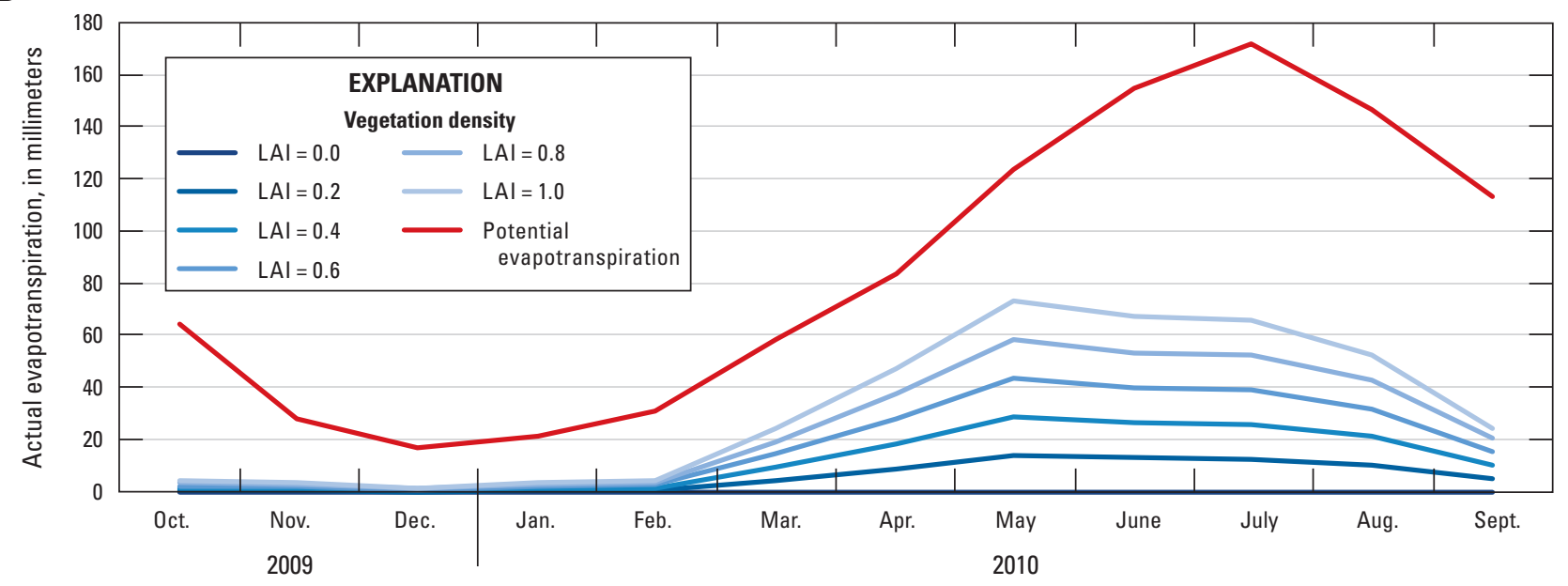

Figure 15. Sensitivity of actual evapotranspiration to the LAI (leaf area index or density) vegetation parameter for two vegetation types: $A$, Douglas fir, and $B$, lodgepole pine. 
A

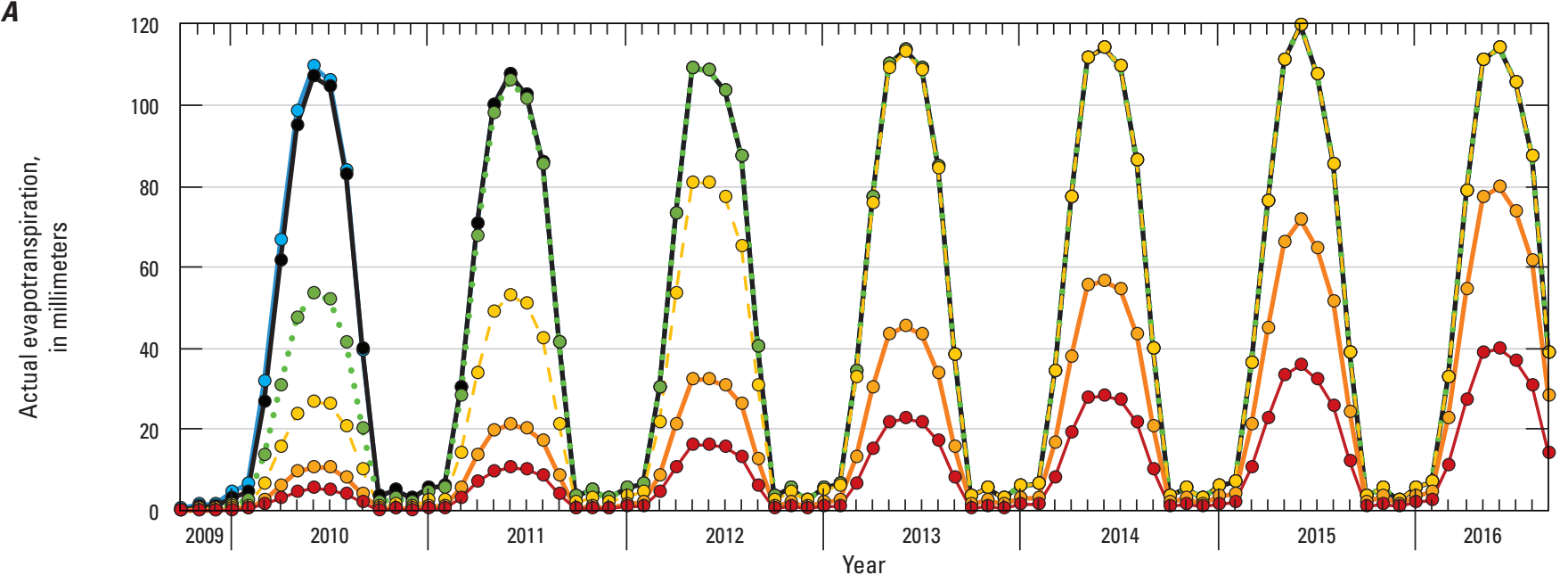

$\boldsymbol{B}$

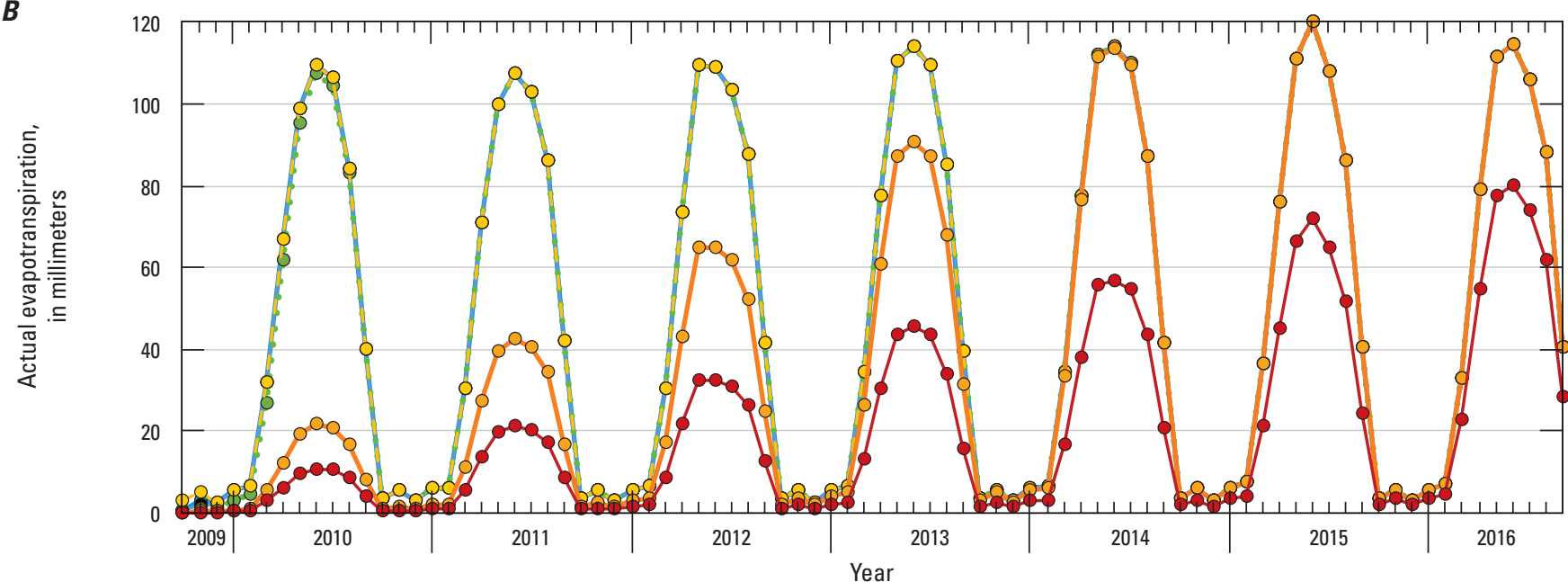

C

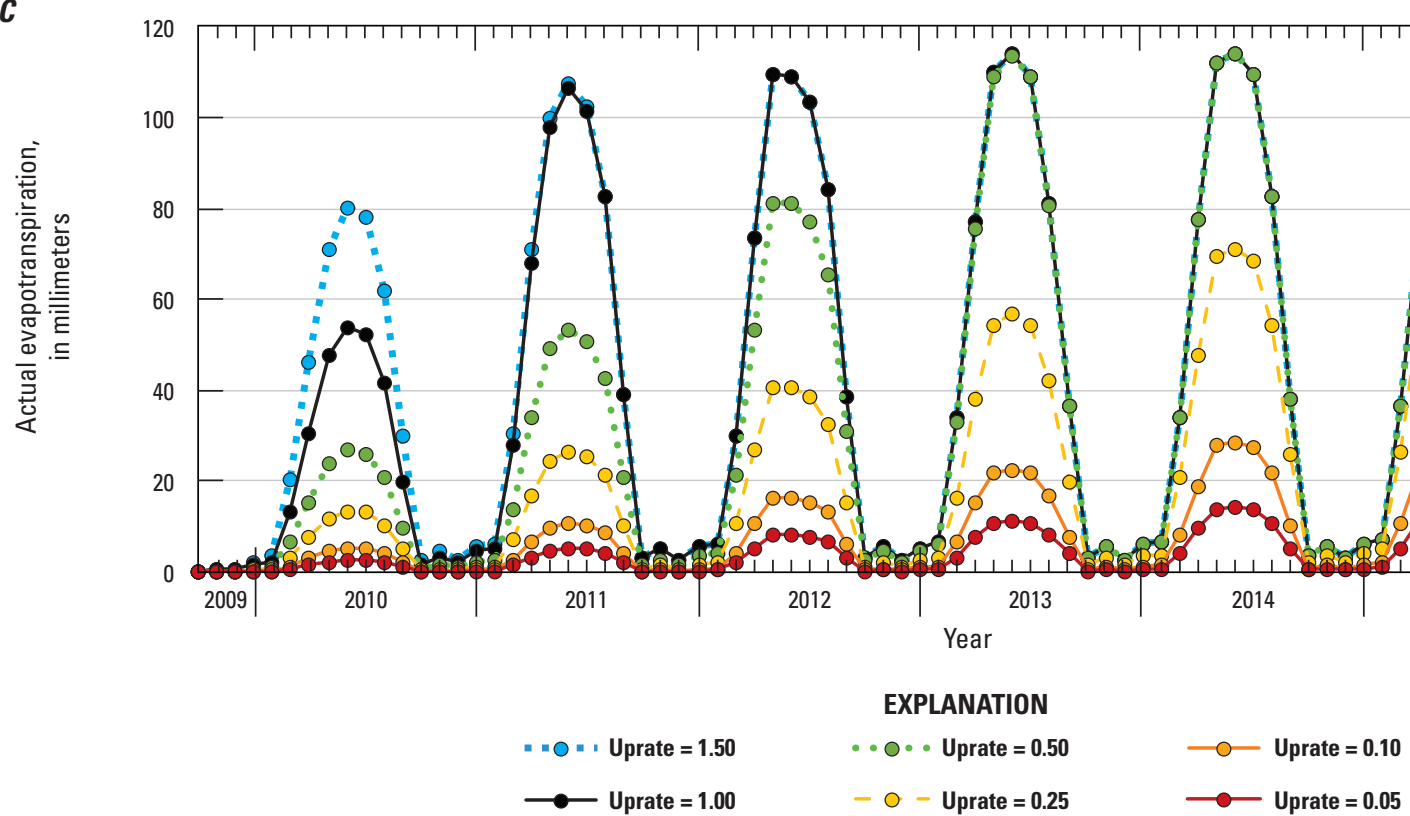

Figure 16. Sensitivity of actual evapotranspiration to the UpRate vegetation parameter following disturbance, where post-disturbance LAI (leaf area index or density) initially equals 0 , in controlling recovery and actual evapotranspiration for $A$, average annual precipitation, $B$, twice the average annual precipitation, and $C$, half the average annual precipitation. 


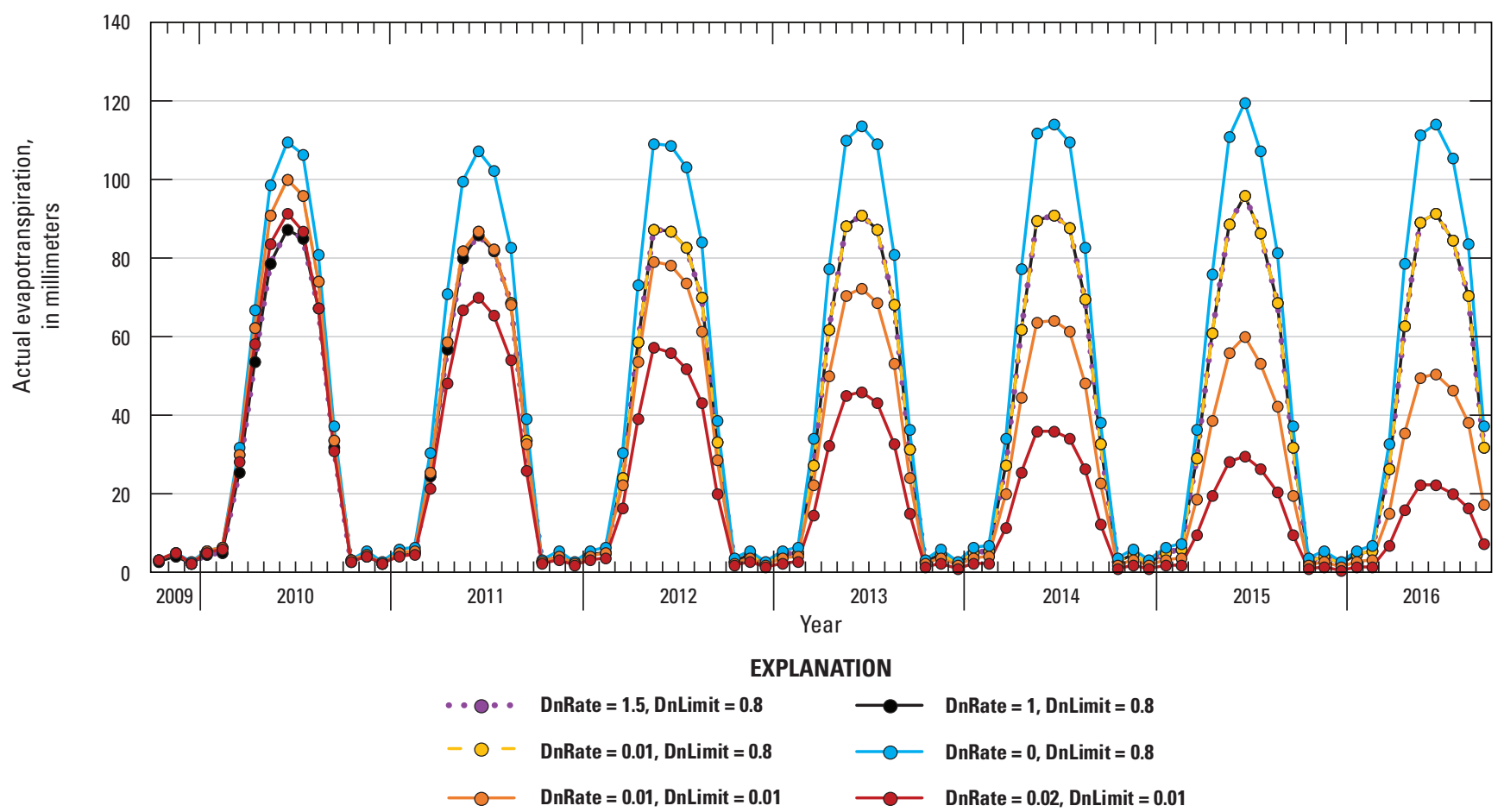

Figure 17. Sensitivity of actual evapotranspiration (AET) to the DnRate vegetation parameter for $L A I=1$ and 50 percent of average precipitation.

\section{Calculation of Streamflow to Match Hydrographs (Using CalBasins.xlsx Spreadsheet)}

The BCMv8 calculates unimpaired recharge and runoff using the water-balance approach described previously and produces recharge, $\mathrm{BCM}_{\text {rch }}$, and runoff, $\mathrm{BCM}_{\text {run }}$, as gridded maps. These water-balance outflows from grid cells upstream from a streamgage with measured streamflow are accumulated for each monthly timestep to produce a time series of $\mathrm{BCM}_{\mathrm{rch}}$ and $\mathrm{BCM}_{\mathrm{run}}$. When run with a basin file for areas upstream from a streamgage, these values are accumulated automatically in the monthly model outfile as rch and run (fig. 5). These data are used with spreadsheet calculations for comparison with measured hydrographs. Equations using $\mathrm{BCM}_{\mathrm{rch}}$ and $\mathrm{BCM}_{\text {run }}$ correspond to variables in figure 18 , which conceptually illustrates how $\mathrm{BCM}_{\mathrm{rch}}$ and $\mathrm{BCM}_{\mathrm{run}}$ flow to a streamgage, and runoff can flow over the surface or move to the shallow zone, some recharge may return to the surface as base flow, and some recharge may be lost to the deep unsaturated zone. These three zones, or groundwater reservoirs, are intended to facilitate matching different parts of the hydrograph iteratively in the calibration spreadsheet.

Post-processing streamflow equations are in the calibration spreadsheet (CalBasins_v8_template.xlsx, available with download of report, in cubic meters $\left(\mathrm{m}^{3}\right)$ or acre-feet flow volumes; fig. 19). The monthly measured streamflow data are copied into column D in cubic feet per second $\left(\mathrm{ft}^{3} / \mathrm{s}\right)$, which is converted to volume for each month in column E. The BCMv8 outfile is copied to the Cal_outfile tab, and $\mathrm{BCM}_{\mathrm{rch}}$ and $\mathrm{BCM}_{\mathrm{run}}$ in the calibration tab (columns $\mathrm{F}$ and G) are linked to columns R and S in the outfile sheet for the correct dates. The area of the basin is entered in cell D5, and volumes of recharge and runoff are calculated automatically in columns $\mathrm{H}$ and I. Calibration equations include BCMv8 map outputs, in bold, and adjustable parameters, in italics. $\mathrm{GW}$ is the water in each of the 3 reservoirs, surface, shallow, and deep.

$$
\begin{aligned}
& \mathrm{GW}_{\text {surface(i) }}=\mathrm{GW}_{\text {surface( }(\mathrm{i}-1)}+\mathbf{B C M}_{\text {run(i) }}-\text { Surfaceflow }_{(\mathrm{i}-1)} \\
& \text { Surfaceflow }_{(\mathrm{i})}=\left(\mathrm{GW}_{\text {surface(i) }}\right)^{\text {SurfaceExp }} \\
& \mathrm{GW}_{\text {shallow(i) }}=\mathrm{GW}_{\text {shallow(i-1) }}+\mathbf{B C M}_{\text {reh(i) }} \\
& \text { - } \text { Surfaceflow }_{(\mathrm{i})}-\text { Deepflow }_{(\mathrm{i})} \\
& \text { Shallowflow }_{(\mathrm{i})}=\left(\mathrm{GW}_{\text {shallow(i-1) }}\right) \text { ShallowExp } \\
& \text { Deepflow }_{(\mathrm{i})}=\left(\mathrm{GW}_{\text {shallow(i-1) }}\right)^{\text {DeepExp }} \\
& \operatorname{RchRun}_{(\mathrm{i})}=\text { Surfaceflow }_{(\mathrm{i})}+\text { Shallowflow }_{(\mathrm{i})}+\text { Deepflow }_{(\mathrm{i})} \\
& \text { BCMflow }_{(\mathrm{i})}=\text { AquiferRch }^{*} \text { Stream }_{(\mathrm{i})}
\end{aligned}
$$




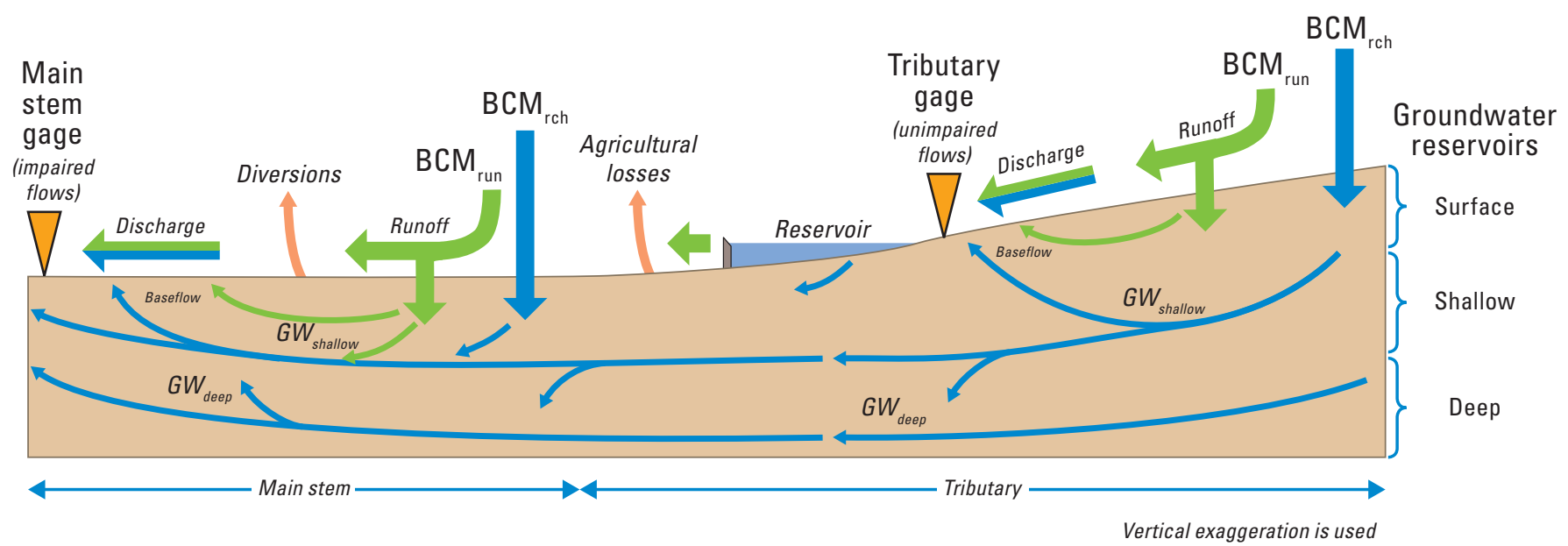

Figure 18. Post-processing of Basin Characterization Model, version 8 (BCMv8), recharge and runoff map outputs to calculate basin discharge for comparison with streamflow measurements.

Equation 3 (column $\mathrm{J}$ in spreadsheet) accumulates surface runoff $\left(\mathrm{GW}_{\text {surface(i) }}\right)$ for each calibration basin using simulated runoff from the $\mathrm{BCMv} 8\left(\mathrm{BCM}_{\mathrm{run}}\right)$ time series; then, equation 4 (column K) applies an exponential decay (SurfaceExp) to the recession in order to match peaks and receding limbs of the hydrograph.

Shallow flow $\left(\mathrm{GW}_{\text {shallow(i) }}\right)$ is accumulated with equation 5 (column $\mathrm{L}$ ) using simulated recharge $\left(\mathrm{BCM}_{\mathrm{rch}}\right)$ to calculate shallow recharge $\left(\right.$ Shallowflow $\left._{(\mathrm{i})}\right)$. Equation 6 (column M) uses exponential decay (ShallowExp) to match the recessions of the hydrograph. Equation 7 (column O) uses exponential decay (DeepExp) to match base flows to help maintain mass balance between the measured and simulated streamflow by limiting the contribution of the shallow groundwater reservoir to streamflow.

Total streamflow $\left(\operatorname{RchRun}_{(\mathrm{i})}\right.$, equation 8; column $\mathrm{P}$ ) is calculated by summing the three components surfaceflow, shallowflow, and deepflow. Finally, simulated basin discharge (BCMflow $_{(\mathrm{i})}$, equation 9; column Q) is calculated by scaling (AquiferRch) the calculated streamflow $\left(\operatorname{RchRun}_{(\mathrm{i})}\right)$ to exactly match total measured flows for the period of record to account for losses to the groundwater system or unknown impairments, diversions, or pumping. The adjustable parameters SurfaceExp, ShallowExp, DeepExp, and AquiferRch are manually changed to visually match the measured hydrograph; exactly match the total measured flows; and optimize goodness-of-fit statistics, daily and monthly $\mathrm{r}^{2}$, and Nash-Sutcliffe Efficiency statistic (NSE).
The adjustable parameters equate to cells in the spreadsheet (fig. 19) in tan (column K). Statistical target cells are in blue, and linked cells are in yellow. An additional adjustment for matching the timing of peaks is in cells $\mathrm{O} 10$ and P10. Graphics for visualization include monthly timeseries in linear and logarithmic formats, a water year comparison in a scatterplot with a line indicating perfect agreement, and an average monthly bar chart of basin discharge to help visualize seasonality of flow, which may be useful in snow-dominated basins to compare the snow accumulation and snowmelt timing. If upstream streamgages record streamflow draining into the basin, such as Happy Isles draining into Pohono (fig. 4), the streamflow from the upstream streamgage may be subtracted from the measured flow in column $\mathrm{D}$, or the $\mathrm{BCM}_{\mathrm{rch}}$ and $\mathrm{BCM}_{\mathrm{run}}$ from the upstream drainage area may be added to column $\mathrm{F}$ and $\mathrm{G}$.

\section{Calibration Tools}

Bedrock-conductivity (GeolK) values correspond to the geologic rock types in the control file shown in table 5 . GeolK default values $\left(\mathrm{GeolK}_{\text {calib }}\right)$ are based on calibrations to streamgages throughout California and the Southwest, initially obtained through expert opinion from USGS geologists, and adjusted to better match measured streamflow data. An example of how GeolK adjustments change recharge and runoff is illustrated in table 9 and figure 20. In this example, the ratio of recharge to runoff is shown on the Y-axis, with values less than 1 signifying more runoff than recharge, and values greater than 1 signifying more recharge than runoff. 


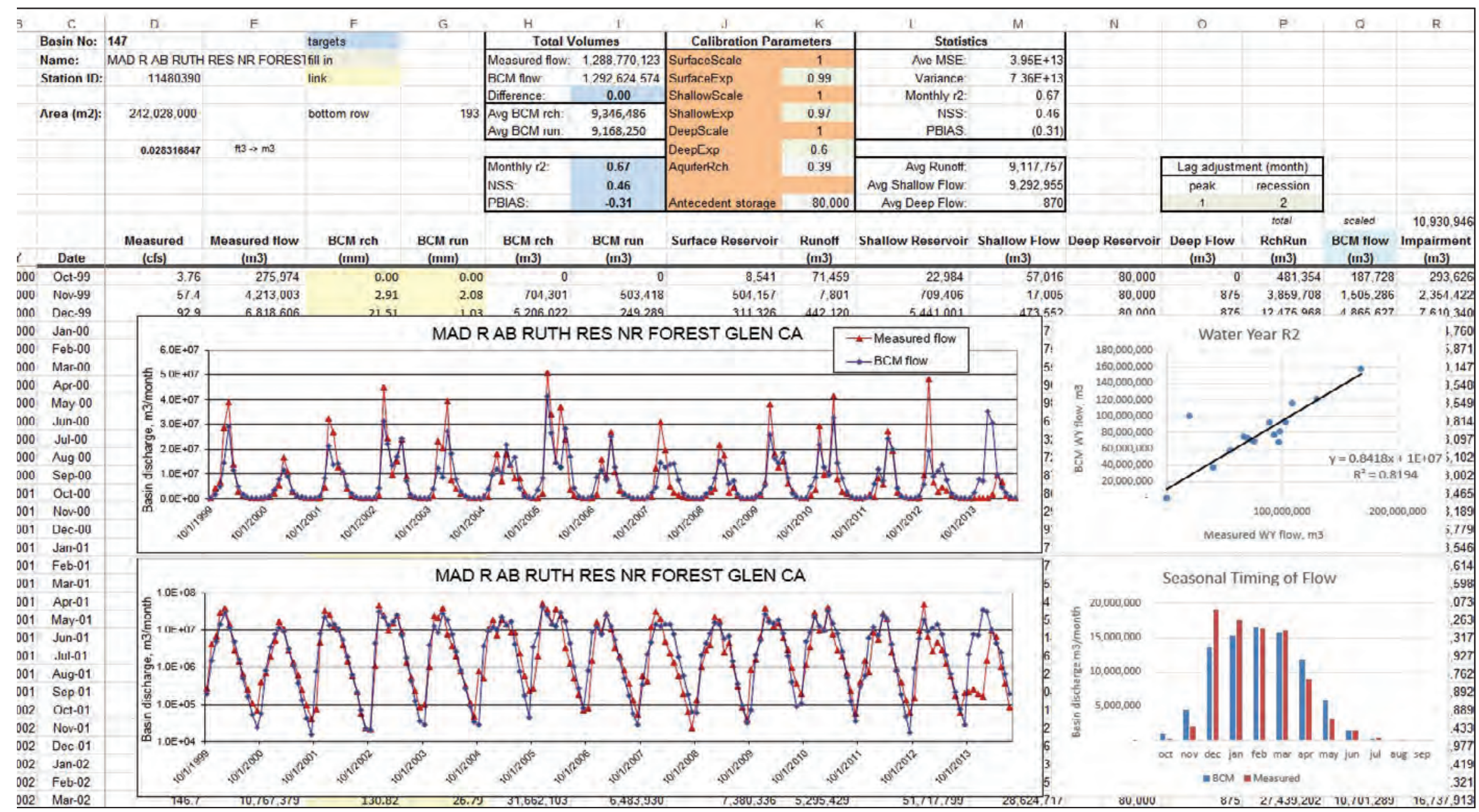

Figure 19. Example calibration spreadsheet. 
Table 8. Suggested value ranges for vegetation parameters for calibration or recovery exercises. The leaf area index density parameter (LAI) is set to 1 only for calibration and can be decreased to simulate a disturbance.

[LAI is set to 1 only for calibration and can be changed to simulate a disturbance. An LAI of 1 is the relative Leaf Area Index under long-term equilibrium conditions; disturbance is a density multiplier in LAI. Rates are decimal percent multipliers of $\mathrm{K}_{\mathrm{V}}$ (precipitation divided by long-term average precipitation) per month as a function of monthly ratio of monthly precipitation to long term average precipitation (ppt/ave ppt). Limits are the ranges of LAI (actual evapotranspiration; AET) bracketing how responsive it is to ppt/ave ppt. RootDepth is the increase in soil volume accessed by vegetation below mapped soil depth expressed as a depth in meters.]

\begin{tabular}{lll}
\hline \multirow{2}{*}{ Parameter } & \multicolumn{2}{c}{ For calibration or recovery } \\
\cline { 2 - 3 } & Lower & Upper \\
\hline LAI & 0 & 1 \\
UpLimit & 1 & 3.5 \\
DnLimit & 0.5 & 1 \\
UpRate & 1 & 2.5 \\
DnRate & 0.5 & 1 \\
RootDepth & 0 & 2.5 \\
$\mathrm{~K}_{\mathrm{v}}$ & 0.01 & 0.95 \\
\hline
\end{tabular}

Table 9. Sensitivity of recharge/runoff ratio to a range of bedrock conductivities in millimeters per day for two geologic rock types and a range of basin precipitation values.

[K, conductivity; mm/day, millimeter per day; ID, identification; $\mathrm{mm} / \mathrm{yr}$, millimeter per year $]$

\begin{tabular}{|c|c|c|c|c|c|c|c|c|}
\hline \multirow{2}{*}{$\begin{array}{c}\text { Geology } \\
\text { Basin ID }\end{array}$} & \multicolumn{4}{|c|}{ Mixed granite, $K=0.01 \mathrm{~mm} / \mathrm{day}$} & \multicolumn{4}{|c|}{ Sandstone/shale, $K=4$ mm/day } \\
\hline & 45 & 33 & 87 & 102 & 95 & 77 & 107 & 128 \\
\hline $\begin{array}{l}\text { Precipitation } \\
\text { (average } \\
\text { annual, } \\
\mathrm{mm} / \mathrm{yr} \text { ) }\end{array}$ & 2,598 & 2,708 & 4,184 & 4,941 & 1,567 & 2,545 & 4,324 & 7,325 \\
\hline $\mathrm{K} \times 0.5$ & 0.18 & 1.6 & 3.01 & 1.13 & 0.48 & 0.62 & 0.93 & 0.63 \\
\hline $\mathrm{K}$ calibrated & 0.28 & 2.2 & 4.48 & 2.00 & 0.55 & 0.98 & 1.92 & 1.21 \\
\hline $\mathrm{K} \times 2$ & 0.42 & 2.4 & 4.56 & 2.54 & 0.56 & 1.02 & 1.93 & 1.34 \\
\hline $\mathrm{K} \times 3$ & 0.56 & 2.4 & 4.56 & 2.65 & 0.56 & 1.0 & 1.93 & 1.35 \\
\hline $\mathrm{K} \times 10$ & 1.90 & 2.6 & 4.56 & 3.21 & 0.57 & $1.0^{\circ}$ & 1.93 & 1.35 \\
\hline
\end{tabular}

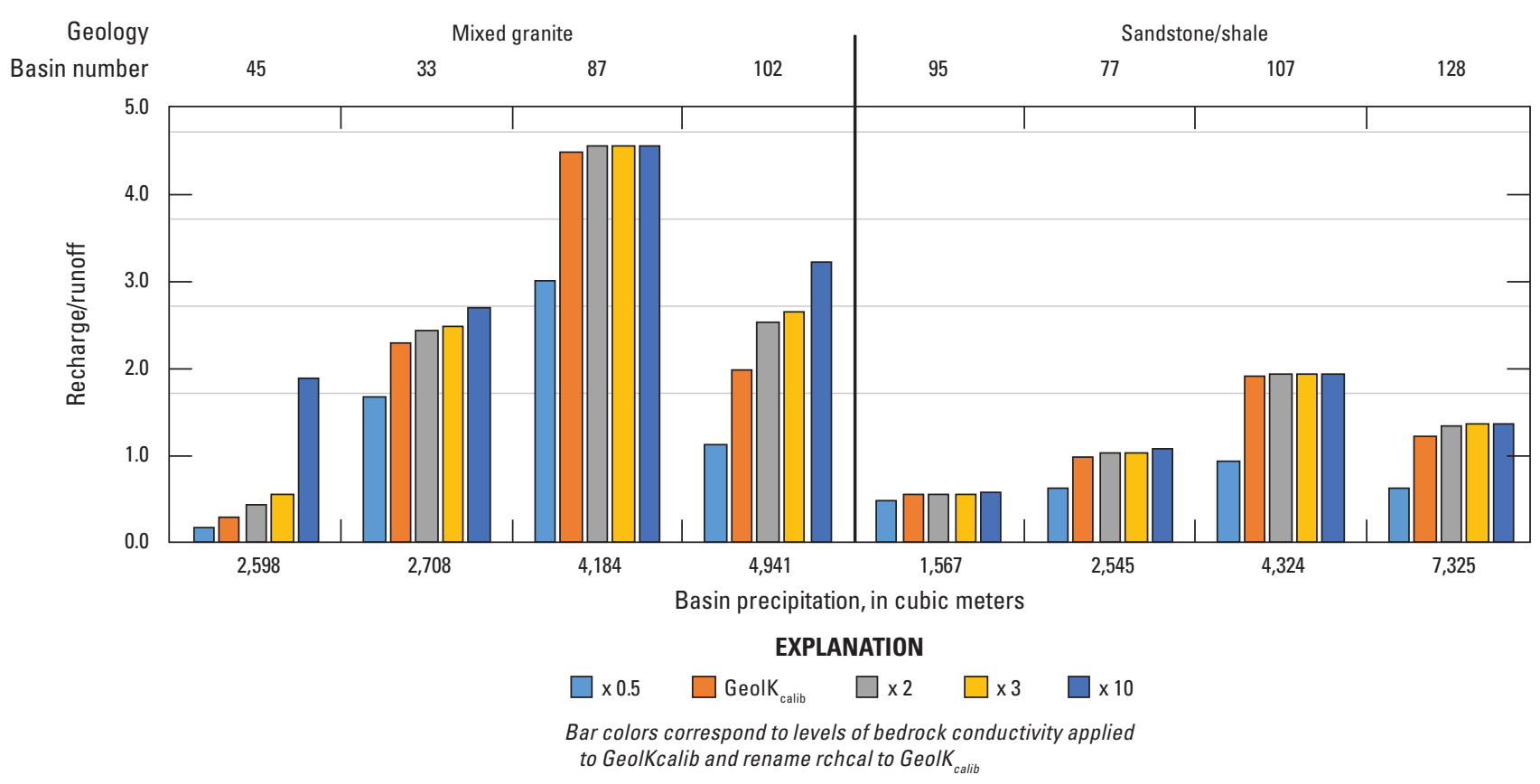

Figure 20. Sensitivity of the recharge/runoff ratio relative to bedrock conductivity for different geologic rock types and climatic conditions. 
The GeolK values tested are the default $\mathrm{GeolK}_{\text {calib }}$ and four multipliers (x0.5, x2, x3, and $\mathrm{x} 10)$, for two geologic types: one a mixed granite with an initially low GeolK value, the other a sandstone-shale with a relatively high GeolK value. For each geologic type, four basins having a range of average precipitation conditions were selected to illustrate the sensitivity of recharge and runoff to GeolK. In figure 20, the orange bar corresponds to the default value of GeolK $\mathrm{Calib}_{\text {, }}$ and for all basins, the ratio of recharge to runoff goes down if GeolK is halved and goes up with each subsequent increase in GeolK. This indicates that recharge increases at the expense of runoff where bedrock conductivity is increased. The changes are greater for the granite than for sandstone-shale, however, and for some basins, there is a point at which further increases in GeolK do not change the ratio. Additionally, sensitivity to changes in GeolK for the sandstone-shale basins all become muted at bedrock conductivities greater than $\mathrm{GeolK}_{\text {calib }} \mathrm{x} 2$.

Changing the GeolK changes the recharge relative to runoff, which may be needed to match the hydrograph, where more or less recharge or runoff is needed, but it may also change the total flow depending on soil properties, timing of precipitation, AET, and so on.

Statewide calibration using default parameters based on maps of vegetation types or geology averaged for large regions has been completed for California. A local calibration can be done to refine the calibration using average vegetation parameters and bedrock conductivity values for much smaller areas. This process is started by clipping the existing layer files and climate files to the smaller region of interest, such as a watershed or geopolitical boundary using the FORTRAN code "Clipgrid" (appendix 3).

\section{Soil Properties}

Gridded soil-property maps of porosity, soil water content at field capacity and wilting point (meter water per meter soil), soil depth (meters), and soil saturated hydraulic conductivity (Ksat, millimeter per day) are required for the BCMv8 water-balance calculations and are available for the United States and select nearby countries: (https://datagateway.nrcs.usda.gov).

To develop soil-property grids of Ksat, water content at field capacity, and water content at wilting point on the basis of texture and soil organic matter using the FORTRAN code "SoilProps," refer to the procedure in appendix 2. Equations from Saxton and Rawls (2006) were used to calculate soil water content at field capacity and wilting point from soil texture and soil organic matter at a range of water potentials. Data from approximately 4,000 soil samples were used to develop and validate the regression equations that use percentages of sand, silt, clay, and soil organic matter to estimate field capacity and wilting point for a range of water potentials as well as estimates of Ksat. In SoilProps, field capacity is calculated at soil-water potentials of 0.1 and $0.33 \mathrm{MPa}$, and wilting point is calculated at $1.5,3.0$, and 6.0 MPa, whereas the standard wilting point is generally calculated to $1.5 \mathrm{MPa}$ only. To run SoilProps for the study area, soil grids of percentages of sand, silt, clay, and soil organic matter, as well as bulk density and porosity, must be downloaded, clipped, and exported as ASCII files. The complete procedure can be found in appendix 2 .

Choosing a field capacity of $0.01 \mathrm{MPa}$ and wilting point of 6.0 MPa increases the water-holding capacity compared to a field capacity at $0.033 \mathrm{MPa}$ and wilting point at $1.5 \mathrm{MPa}$. Different combinations of field capacity and wilting point maps can be used depending on calibration needs.

\section{Snow Parameterization}

To develop a site-specific snow-parameter calibration for an area outside of California, or for a local basin that has measured data, local observed snow data are downloaded to compare to the modeled BCMv8 snow for optimization of the snow parameters used in the Snow-17 model (Anderson, 2006). The default values of the monthly adjustment factor (maf), a model parameter between 0 and 1 (tipm), and the maximum negative melt factor ( $\mathrm{nmf}$ ), are representative of North America, and define the maximum melt as June 21. The snow-accumulation temperature and maximum and minimum melt factors are calibrated using available local data. If no local data exist, a uniform set of parameter values can be set in the BCM_Monthlyv8 control file. These parameters can be adjusted to improve the seasonal hydrologic calibration and snowmelt signature for the area (see the "Calibrating the BCMv8 Recharge and Runoff to Local Streamflow" section in appendix 3). If there is no snow in the region, the snow parameters can be set to a value of 1 or left at default values.

To develop spatially distributed snow-parameter maps for the study area of interest, download available snow-sensor or snow-pillow data for the area. Run the BCMv8 using a basin file that has point locations of the snow data using different combinations of snow parameters to iteratively find the best fit of snow parameters for each location. Using geostatistics, interpolate the calibration parameters across the study domain. Smoothing techniques can also be applied to improve the parameter maps. For a step-by-step procedure of the snow-parameterization process, refer to appendix 2 . 


\section{Post Processing}

Several FORTRAN codes are available to help the user summarize and perform analyses of the BCM outputs. The codes "AddGrids" and "AveGrids sum or average monthly BCMv8 outputs in longer time spans, such as a water year or calendar year, for further analysis or visualization. AddGrids is used to sum monthly maps to create a cumulative map and is generally appropriate for summing a year of precipitation, potential evapotranspiration, climatic water deficit, recharge, or runoff. AveGrids does the same, except it averages the months instead of summing them, and is generally used to create average temperature maps or to average multiple water year files. The AddGrids and AveGrids control files require the name of the new file, the number of files to add or average, and a list of the file names (fig. 21).

The FORTRAN code "Linreg" can be used to perform statistical analyses, such as average, standard deviation, coefficient of variation, detrended standard deviation, slope, intercept, and $\mathrm{R}^{2}$ of a selection of water years, to calculate the statistics for 30-years or average monthly means for some other time period. The Linreg control file (fig. 22) requires the names of the new files, the number of files to read, and a list of the files to be read. The control files can be called in a batch file to calculate water years from monthly maps and perform statistical analyses in sequence.

Other post-processing applications include extracting time series for applications to other models, such as providing boundary conditions for groundwater models. This is done with the FORTRAN code "BasinExtractv1" to post process selected portions of subwatersheds for ancillary analysis or as input to other applications such as the new MODFLOW One-Water integrated hydrologic model (OWHM; Boyce and others, 2020; Hanson and others, 2014a). See application 7 for an example and figure 3.2 for example control file. For example, this code is used to extract and sum recharge and runoff in subwatersheds that are surrounding the active model grid of OWHM models for input to the streamflow routing network as surface inflows or as mountain-block recharge as input through the Flow-Head Boundary (FHB) package or simply as virtual wells along the boundary of the OWHM Model. This operation provides a passive linkage of inflows for both historical and future climate-change simulations where complete linkage is unnecessary but the inflows from surrounding areas are required for a complete representation of inflows throughout the valley portions of the watershed. The program can also be used to extract selected regions or raster pixels from $\mathrm{BCMv} 8$ output arrays to extract time-series needed to classify future months, seasons or years as wet and dry needed for binning other related input features of OWHM models, such as future diversions or climate-related stress scale factors for crop coefficients, fractions of transpiration, and on-farm irrigation efficiencies.

Other post processing applications using "BasinExtractv1" include the mapping of BCMv8 output of precipitation, PET, and LAI onto OWHM model grids as monthly arrays that become input to the Farm Process for driving supply, irrigation demand, and transpiration canopy, respectively. Also, post processing can be used to compare against time series from local climate stations for developing scale factors of PET between monthly estimates of the BCMv8 and local Pennman-Monteith estimates, or at streamflow gages for assessing base flow or stormflows and related statistics such as streamflow duration analysis; such analyses of streamflows are useful for wet and dry multi-year periods to help assess groundwater-dependent ecosystems and streamflows needed for fish migration.

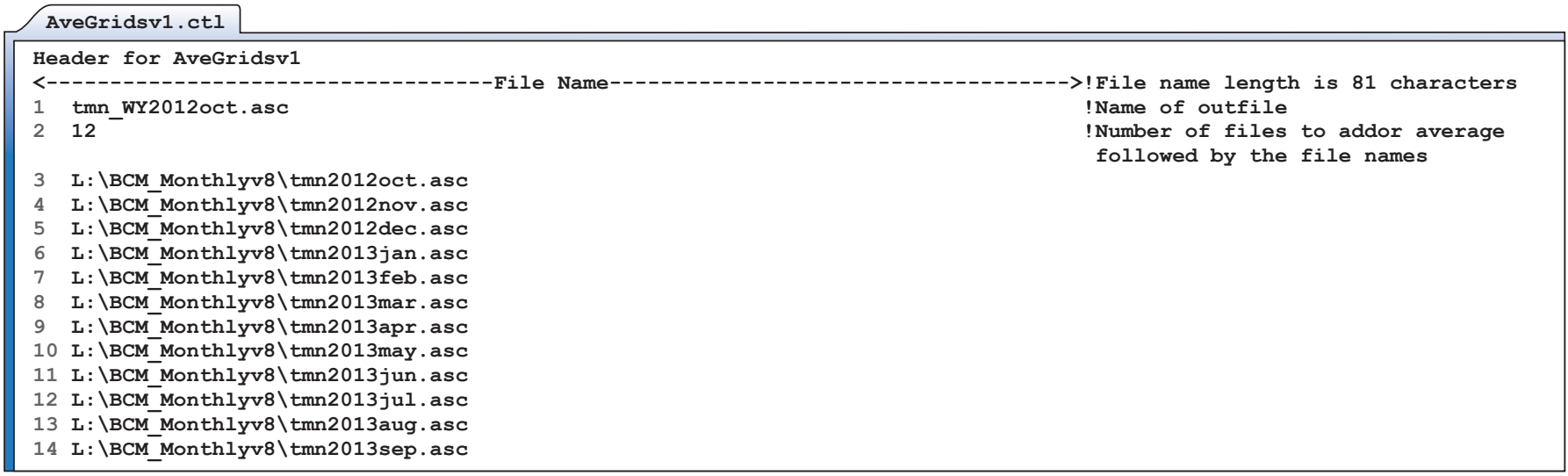

Figure 21. Example control file for AddAveGrids (AddAveGridsv1.ctl) 


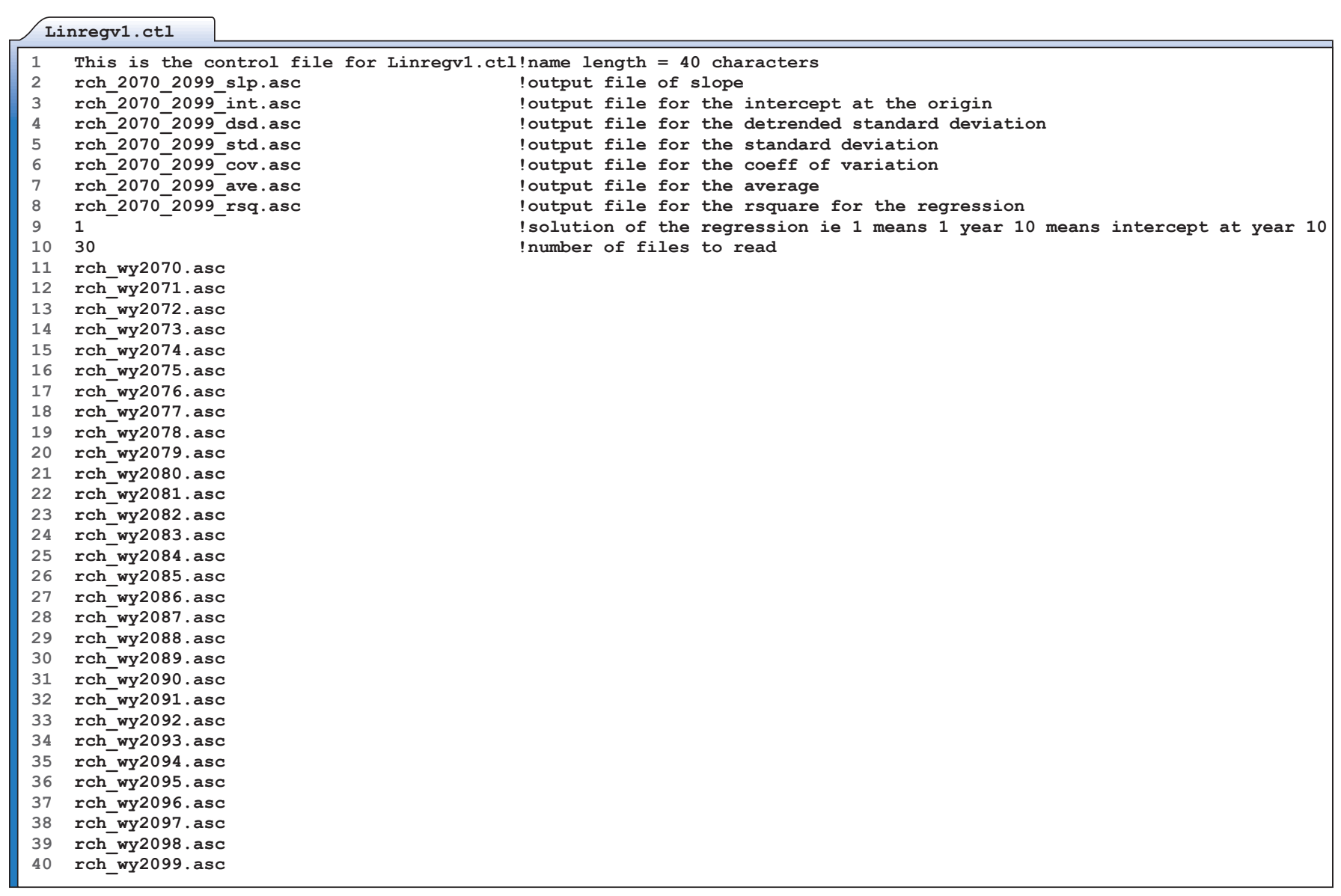

Figure 22. Example control file for Linreg (Linregv1.ctl).

\section{Model Uncertainties and Limitations}

Some of the potential sources of error in input variables are well known to geographers. Soil maps are particularly prone to error because accurate determinations of soil depth are difficult and currently unobtainable for large areas. County-level soil maps (SSURGO) provide good spatial detail on soil types and properties, but soil depth information is limited in locations where soil depths are greater than 2 meters. Human activities are extensive in California and likely affect nearly every basin. Activities that can affect the hydrology at the watershed scale include small impoundments, direct pumping from streams for urban or agricultural use, construction of impermeable surfaces, and changes to the natural land cover. These activities can variously affect the partitioning of input precipitation (PPT) to different pathways in the hydrologic cycle and the actual evapotranspiration (AET) and PET calculated as part of the model.

If the model is adequately parameterized to estimate basin discharge in unimpaired locations, then the model can be used to assess nearby ungaged locations that have similar physical watershed characteristics. Similarly, the model could be used to assess the extent of effects impairments could have on basin discharge. The estimate of spatially distributed runoff does not equal basin discharge as measured at a streamgage without post-processing to determine the components of runoff and recharge that contribute to stream-channel gains and losses, which must be done using measured data for a given basin. The resultant parameters corresponding to the gains and losses generally reflect climatic conditions and geologic setting, but at the scale of California, have not been determined to a degree that allows for the direct extrapolation of basin discharge to all ungaged basins. The spatial distribution of runoff and recharge, however, provides relative differences for the region and can indicate the differences among basins in sensitivity to changes in climate. The estimates of changes in soil-water content and CWD do not rely on interpretation of bedrock permeability, and uncertainties correspond more closely with those of the mapped soil properties and climate data. 
Because the BCMv8 model outputs are calculated on a grid-cell basis, results can be summarized across landscapes using summary units of any size of interest such as a point, watersheds, ecoregions, or political boundaries. The ability to spatially project hydrologic model outputs permits the cross-comparison of these landscape delineations by using mapped outputs of interest to various fields of research. The limitations to the appropriate spatial application can be small if the underlying input properties are accurate because the energy-load calculations are based on the resolution of the digital elevation model, in this case, $270 \mathrm{~m}$. The variables most closely associated with energy loads (PET, AET, CWD) could potentially be applied at the hillslope scale, given the resolution of SSURGO soils data for most locations. It is recommended that most hydrologic applications be considered at no less than the size of planning watersheds, however (California Intergency Watershed Map of 1999; https://map.dfg.ca.gov/metadata/calw221_polygon_ 20131205_wm.html).

\section{Example Applications}

The BCMv8 can be used for a variety of applications including managing vegetation or soils, modeling climate change, assessing effects on water availability and reduction of landscape stress, or developing groundwater models. In this section, we describe seven applications to illustrate various ways the BCMv8 can be used.

\section{Application 1: Effects of Urbanization on Hydrology}

In this application, we change the soil properties to simulate a low level of perviousness indicative of the urban footprint to evaluate the effects on recharge and runoff. Although this example does not specifically calibrate the soil adjustment to known changes in the historical urban footprint, we do show how future projections of urbanization affect hydrology. The example watershed is Alameda Creek, which drains to southeastern San Francisco Bay (fig. 1, fig. 23). Recharge and runoff are shown for the basin in figures $23 \mathrm{~A}$ and $B$, with the groundwater basin boundary shown. The recharge is primarily on the slopes to the north and west of the groundwater basin, and runoff greater than 100 millimeters per year ( $\mathrm{mm} /$ year) is almost solely in the southern half of the basin. The projections of future urbanization (based on the global climate model GFDL for the A2 business-as-usual emissions scenario) are shown in figure $23 C$ by the 2010 footprint in red, primarily on the alluvial valley floor where the groundwater basin is located. Each future 30 -year period simulates the urbanized area expanding outward and into the hills where water is primarily recharged.

Soil depth was changed to $0.1-\mathrm{m}$ thickness for each grid cell denoted as urban in ArcGIS. The BCMv8 was run for the future climate starting at 2010, and for every decade, the projected expansion of the urban footprint was added to the soil-depth map. The recharge and runoff water year time series are shown for the Alameda Creek scenario for 2010-2100 with and without the changes in soil depth to simulate urbanization (fig. 24). Without changes in urbanization, recharge was the same or slightly greater than runoff for most years. With increases in urbanization included, the recharge was less than runoff for nearly all years. This was most pronounced in high runoff years, but even in relatively low runoff years toward the end of century the runoff is far higher than the recharge. As urbanization expanded up into the recharge areas around the groundwater basin, recharge decreased and runoff increased. Unless infrastructure is in place to capture this excess water, it will flow to the bay and reduce water availability in the basin.

\section{Application 2: Effects of Wildfire on Hydrology}

In this application, we are testing the effects of wildfire on streamflow and demonstrating how to simulate the removal of vegetation by fire. The example fire is the Rim Fire of August 2013 in the Tuolumne River basin for which the fire perimeter is indicated, and the burn-severity index (https://fsapps.nwcg.gov/baer/baer-imagery-support-datadownload) ranged from 0 for no burn to 4 for maximum burn severity (fig. 25). The effects of this wildfire on the post-fire streamflow were slight because of the drought, but this case illustrates the technique of scaling the density parameter (LAI) and using INGEST to bring it into the model. This technique could be used in similar analyses for which gridded vegetation density is available, such as from U.S. Forest Service survey records. 


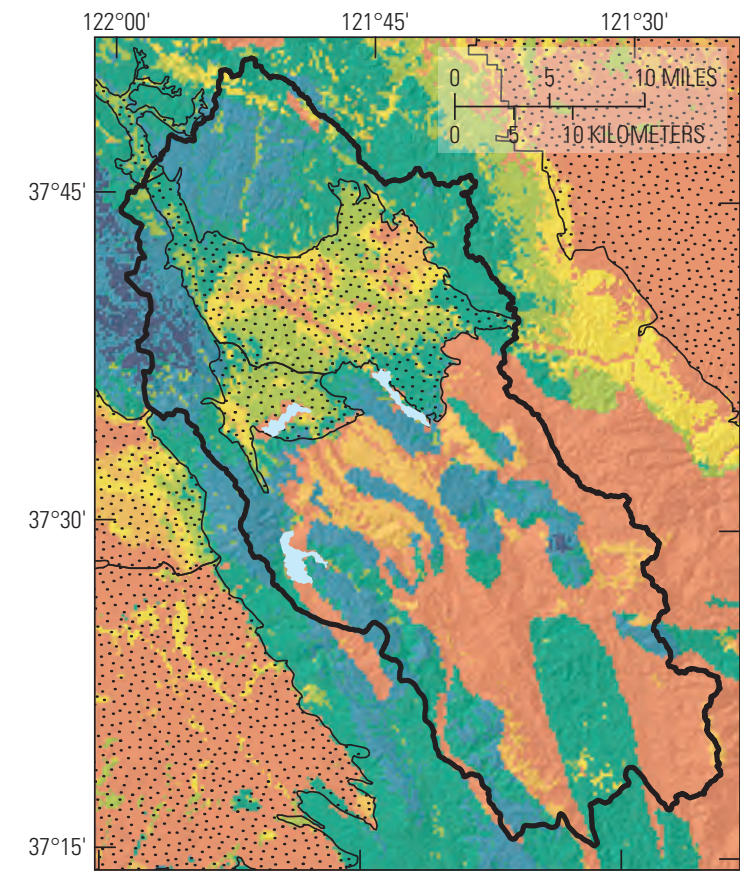

Base modified from U.S. Geological Survey digital data, various scales; Albers Equal Area Conic projection, standard parallels are $34^{\circ} 00^{\prime \prime}$ and 40³0"; North American Datum of 1983

EXPLANATION

Recharge 1981-2010, in millimeters per year

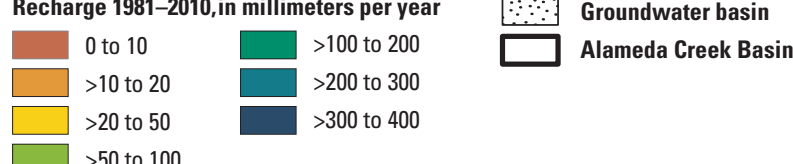

C

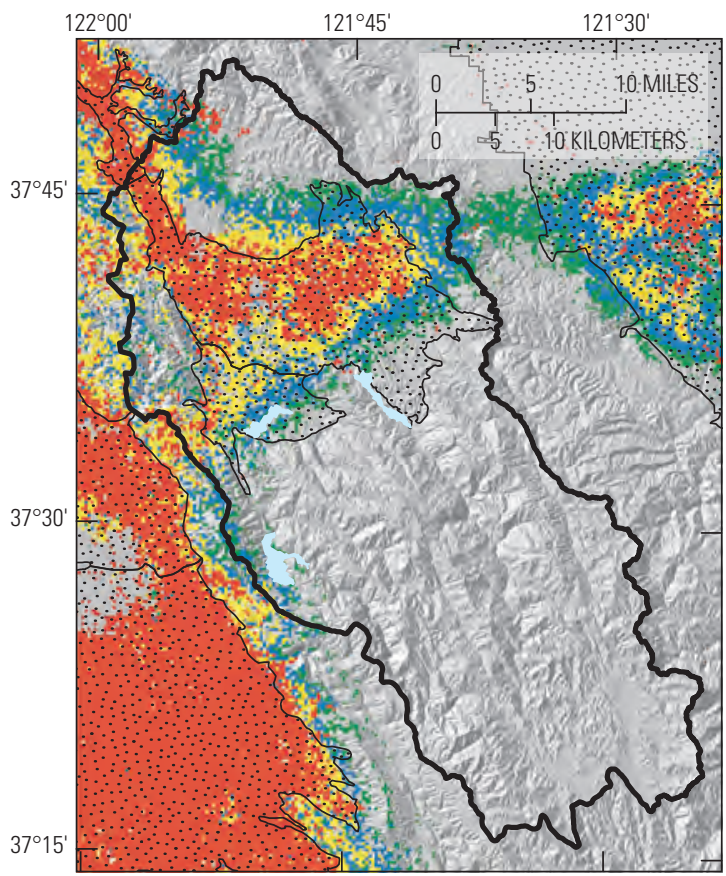

B

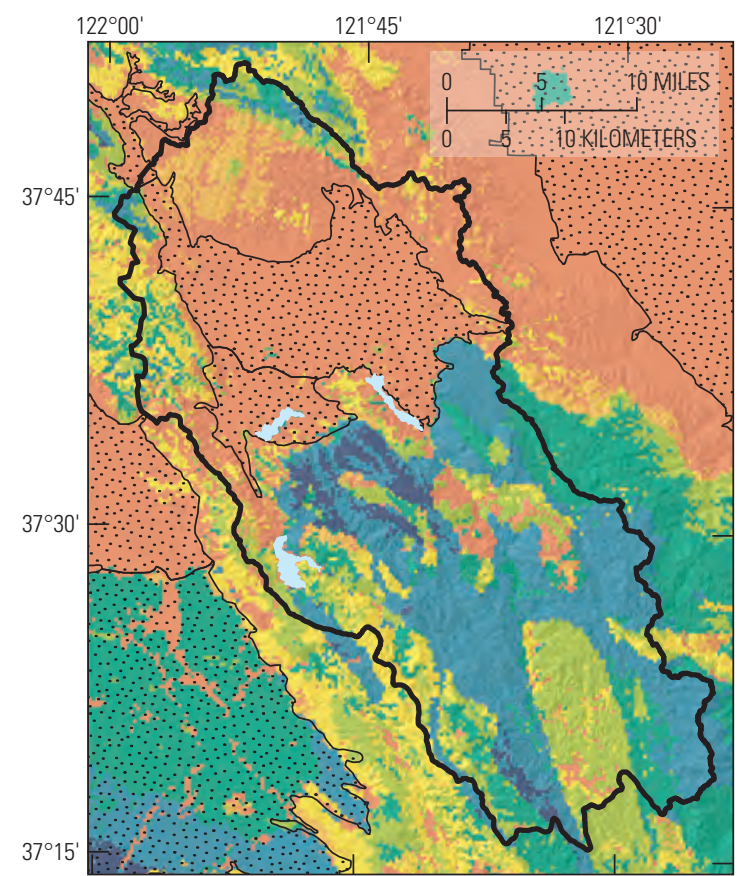

Base modified from U.S. Geological Survey digital data, various scales; Albers Equal Area Conic projection, standard parallels are $34^{\circ} 00^{\prime \prime}$ and 40³0"; North American Datum of 1983

\section{EXPLANATION}

Runoff 1981-2010, in millimeters per year

\begin{tabular}{|c|}
\hline 0 to 10 \\
\hline$>10$ to 20 \\
\hline$>20$ to 50 \\
\hline
\end{tabular}

roundwater basin Alameda Creek Basin

\section{EXPLANATION}

Current and projected urbanization

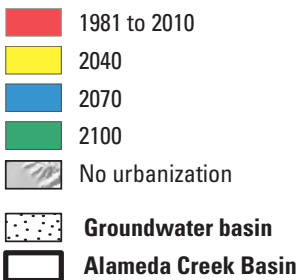

Base modified from U.S. Geological Survey digital data, various scales; Albers Equal Area Conic projection, standard parallels are $34^{\circ} 00^{\prime \prime}$ and $40^{\circ} 30^{\prime \prime}$; North American Datum of 1983

Figure 23. Examples of projected urbanization in drainage basin of Alameda Creek, California, showing water years 1981-2010 $A$, recharge; $B$, runoff; and $C$, future projections of increased urbanization. 


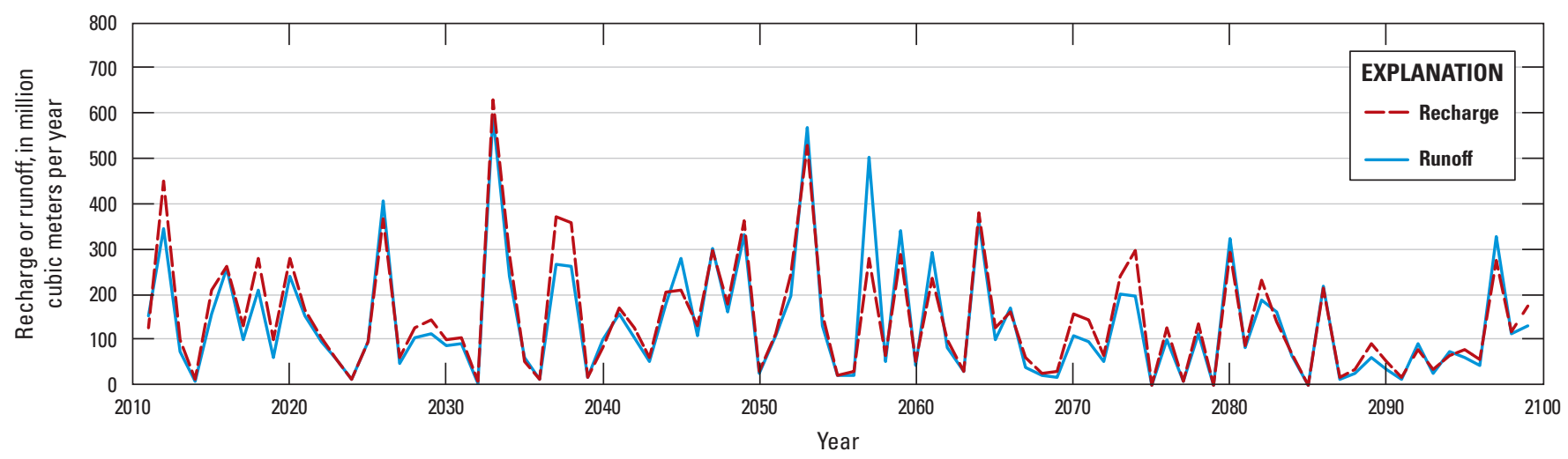

B

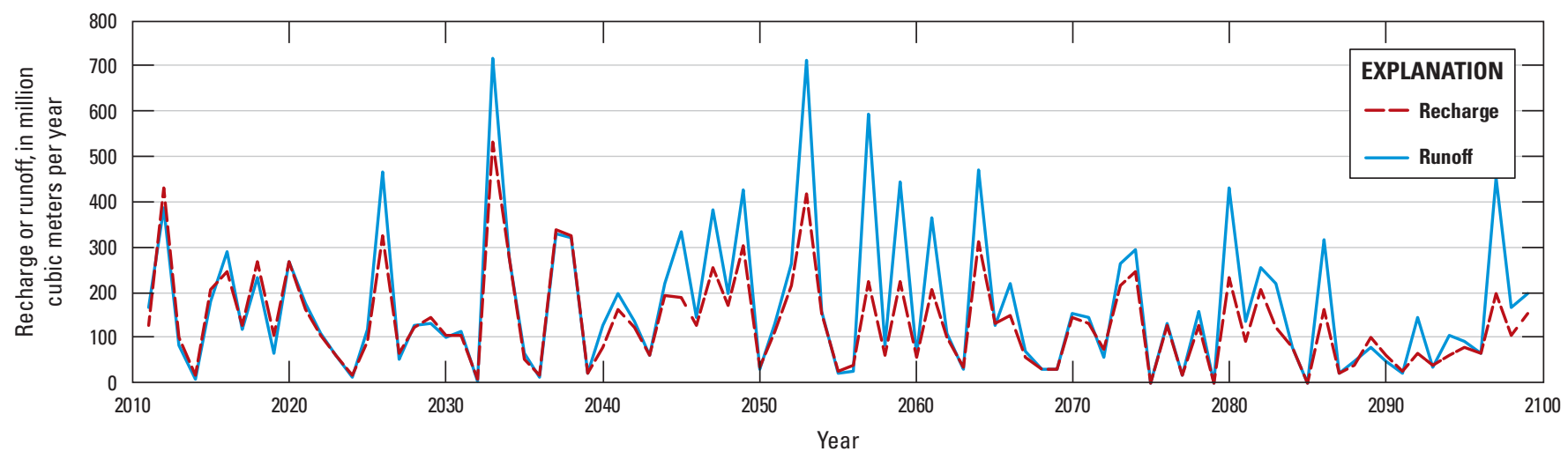

Figure 24. Change in runoff and recharge in Alameda Creek Basin, California, under a future climate scenario $A$, without urbanization projections, and $B$, with increased urbanization projections applied decadally.

First, we isolated the locations where there were streamflow data coincident with the burned area. In this case, one streamgage within the fire perimeter (Tuolumne River above Early Intake near Mather CA, USGS 11276600) was active, and when the data for the upstream streamgage measuring outflow from Hetch Hetchy Reservoir (Tuolumne River near Hetch Hetchy CA, USGS 11276500) were subtracted, the effect of the fire on streamflow within the boundary on figure $25 \mathrm{~A}$ could be assessed. The BCMv8 was run for pre-fire climate, and the CalBasin spreadsheet was used to match the pre-fire hydrograph for October 2010August 2013. When run for post-fire conditions with pre-fire calibration, the BCMv8-simulated streamflow, in dark blue (full LAI), underestimated the measured flow, in red (fig. 26), indicating an effect on measured flow by the reduction in vegetation. Simulating post-fire conditions generally includes two aspects of the burn, removing vegetation and simulating hydrophobicity (water-repellency) of soils. In the absence of hydrophobicity information, which is variable spatially and dependent on soil type, soil organic matter, fire intensity, and other factors, we are only simulating loss of vegetation. To do this, we used the LAI parameter to simulate complete removal of vegetation, making all vegetation density and growth factors zero, and reran the model for post-fire climate. These results overestimated the streamflows, shown as light blue line (zero LAI, fig. 26), indicating that we removed too much AET, which in turn became streamflow. To more realistically represent the loss of vegetation, we used the burn-intensity index to develop a vegetation scaler, shown in figure 24 as a percentage of total LAI. There are several ways to apply this scaler. The easiest way is to determine the average scaler value for each vegetation type by using the ZONALSTATS calculation in ArcGIS summarizing only the area of interest (fig. 25B). Then using LOOKUP table 2, we assigned the new average LAI to each of the nine vegetation types in the domain. This allows the vegetation to grow back as a function of climate, and the DnLimit equals the LAI until the LAI reaches the original DnLimit, then it can fluctuate between the two limits in the table. Although this is not spatially explicit, for this small example basin the spatial variability of climate is very small. The results for this run are shown in figure 26 as the orange line (scaled LAI), which more closely matched the measured post-fire streamflow. The growth factors for each vegetation type were kept at their default values so the simulated regrowth was expected accordingly; however, the precipitation in water year 2014 was at a record low, so growth was slight if any. 
A

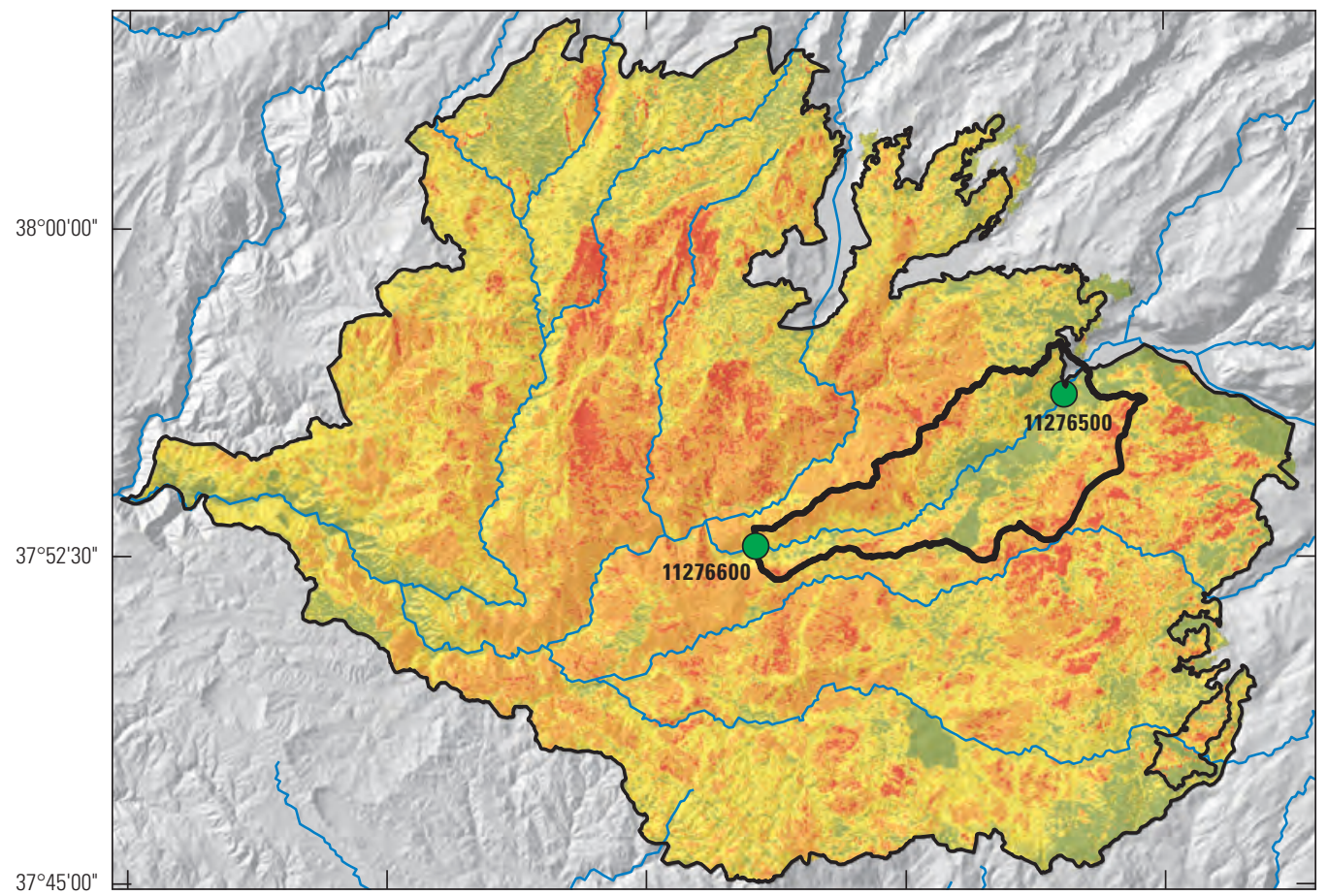

\section{EXPLANATION \\ Burn Severity Index, LAI

\begin{tabular}{ll}
\hline & 0,1 \\
\hline & $1,0.75$ \\
& $2,0.5$ \\
\hline & $3,0.25$ \\
\hline & 4,0 \\
\hline & Calibration basin \\
\hline & Fire perimeter \\
\hline
\end{tabular} \\ Streamgage}

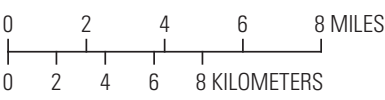

Base modified from U.S. Geological Survey digital data, various scales; Albers Equal Area Conic projection, standard parallels are $29^{\circ} 30^{\prime \prime}$ and 4530": North American Datum of 1983

$B$

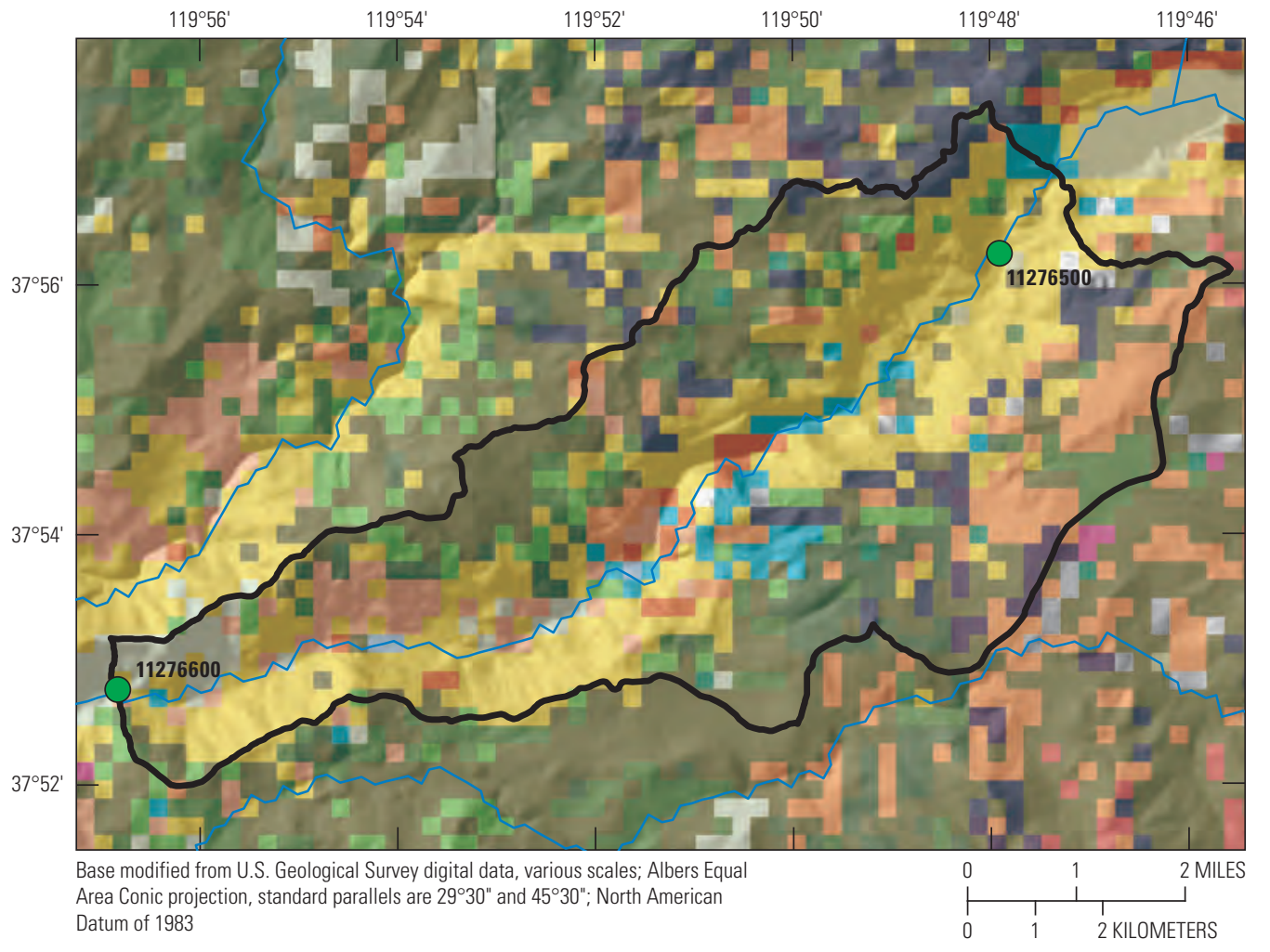

\section{EXPLANATION}

Vegetation type (average burn severity)

Alpine-dwarf shrub Annual grassland Barren

Blue oak-foothill pine Blue oak woodland

Chamise-redshank chaparral Jeffrey pine

Junipe

Lacustrine

Lodgepole pine

Mixed chaparral

Montane chaparral

Montane hardwood-conifer

Montane hardwood

Perennial grassland

Ponderosa pine

Riverine

Red fir

Subalpine conifer

Sagebrush

Sierran mixed conifer

Wet meadow

Rock cliff scree

Annual grassland north

Mixed chaparral south

Montane hardwood south

Calibration basin

Tuolumne Rive

Streamgage

Figure 25. Simulation of the effects of the August 2013 Rim Fire with adjustments to vegetation density (leaf area index, LAl) according to $A$, burn-severity index (https://fsapps.nwcg.gov/baer/baer-imagery-support-data-download) for $B$, vegetation types in calibration basin between two USGS streamgages. 


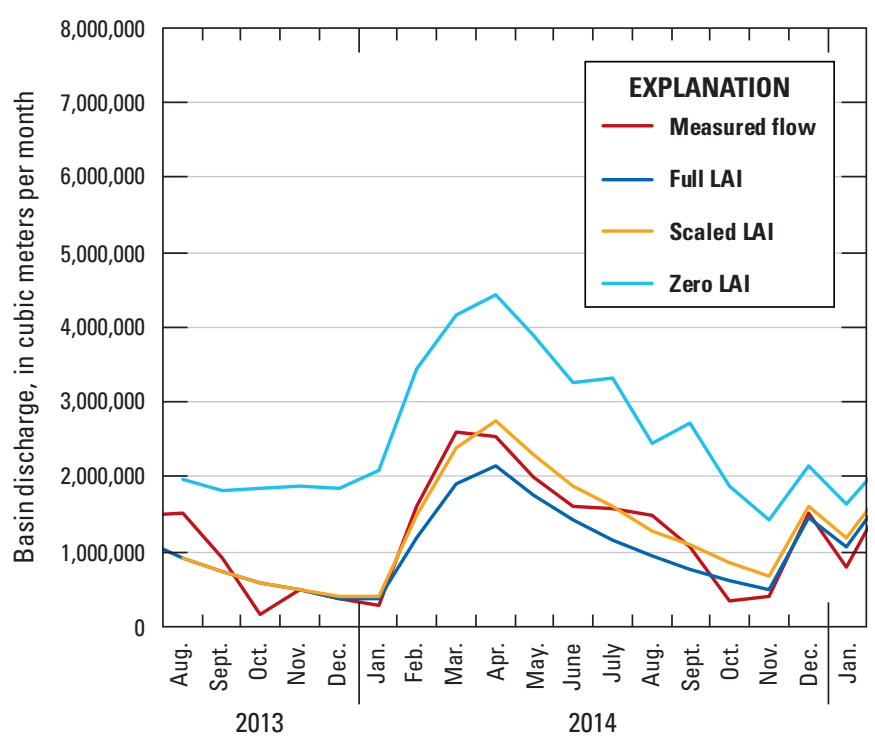

Figure 26. Simulation of the effects of the August 2013 Rim Fire using leaf area index parameter (LAI) on post-fire streamflow of the Tuolumne River downstream from Hetch Hetchy Reservoir, California.

An alternate way to incorporate the scaler is spatially explicit and allows the user to define burned and unburned subareas of the same vegetation type so that growth factors can be manipulated differently for burned and unburned cells. The LAI map can be incorporated directly into the model using the INGEST switch to replace the file "LAI2013aug.asc" as the example for this application. If the fire has burned all the basin, as in this example, then the reduced LAI is applied to all cells, and the growth-rate factors for those vegetation types are applicable. If the entire basin did not burn, however, and you do not want to apply the same growth factors to all cells, then create a BURN ID for each burned vegetation type. Additional rows can be added to the table and used to create new BURN IDs for each vegetation type that burned but also had non-burned cells in the domain. Using the LAI2013aug.asc file in a text editor, find and replace all " 1 "s (for unburned) with "-9999." Now, only cells that burned are ingested. This allows the original vegetation parameters to be active for all unburned cells. Then, for Ponderosa pine for example, find and replace all values of " 42 " with " 142 ." (Remember to save file!) Change the number in LOOKUP table 2 for a new row to 142. Label the Veg Type "Burned Ponderosa Pine" and match the number of vegetation types in line 110 with the correct number of rows. Now it is possible to manipulate the growth factors to simulate post-fire growth for that vegetation type. Repeat this for each vegetation type. To replace a burned vegetation type with a different vegetation type, such as having Annual grasslands replace Ponderosa pine post-fire, replace the growth parameters and monthly $\mathrm{K}_{\mathrm{v}}$ for Ponderosa pine with those from Annual grasslands.

\section{Application 3: Effects of Forest Management on Recharge and Base Flows}

This application is intended to illustrate how forest conditions or vegetation management affect hydrology. Two examples are used here, one showing how forest die-off of specific vegetation types impacts recharge and runoff for a range of water years, the other illustrating how targeted removal of a vegetation type might increase seasonal base flows.

Example 1 is for the Merced-Tuolumne model domain in figure 4 and figure 12, and targets specific vegetation types that experienced die-off during 2013-15. To illustrate this, Ponderosa pine, blue oak woodland, and blue oak-foothill pine vegetation types were targeted by changing the LAI and growth parameters to 0 and running the model for 2010-14, not to simulate this particular climatic period, but to illustrate how recharge and runoff changed in response to a range of water year types, from the wet year of 2011 to the dry year of 2014. The results show that AET was reduced by about 20 percent for these three vegetation types, which compose about 20 percent of the basin (fig. 27) and varied slightly by water year. Recharge and runoff increased for all water years, commensurate with the large decrease in AET. Runoff exceeded recharge in months of high precipitation (Oct.Dec. 2010, and Dec. 2012), and recharge exceeded runoff for months of low precipitation, particularly April 2013Sept. 2014. These results indicate that, for this climate type, recharge is more resilient to drought than runoff, and reduction of leaf area may result in increased base flows, at least in dry years.

A second example investigated whether base flows increase if vegetation density is reduced. This test was applied to the Mad River with the dominant vegetation type of Douglas fir. When the LAI was adjusted to different densities corresponding to differing forest management strategies, the late-summer streamflows dominated by recharge (that is, calculated as base flows in the calibration spreadsheet) changed in response to the reduction in AET, illustrating that decreases in Douglas fir density, and consequently AET, correspond to increases in late-summer basin discharge (fig. 28). 
A

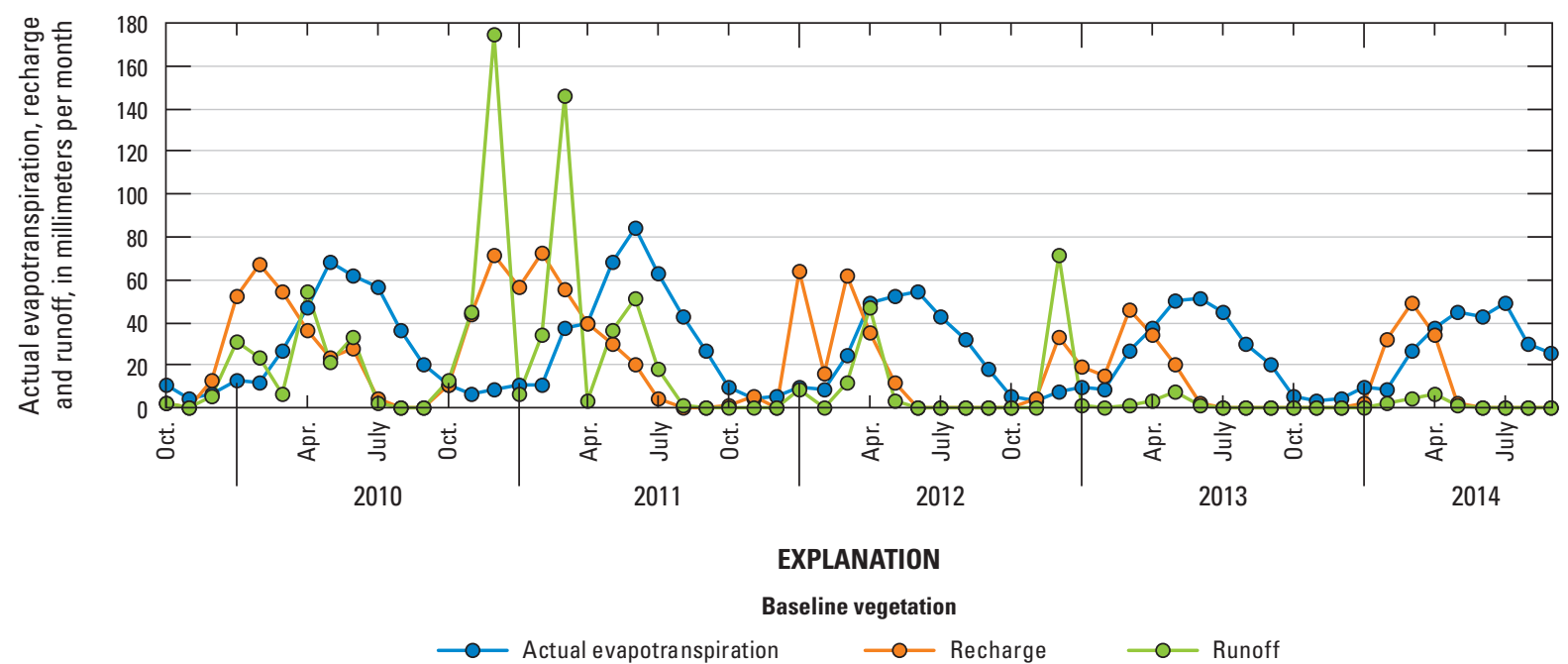

B
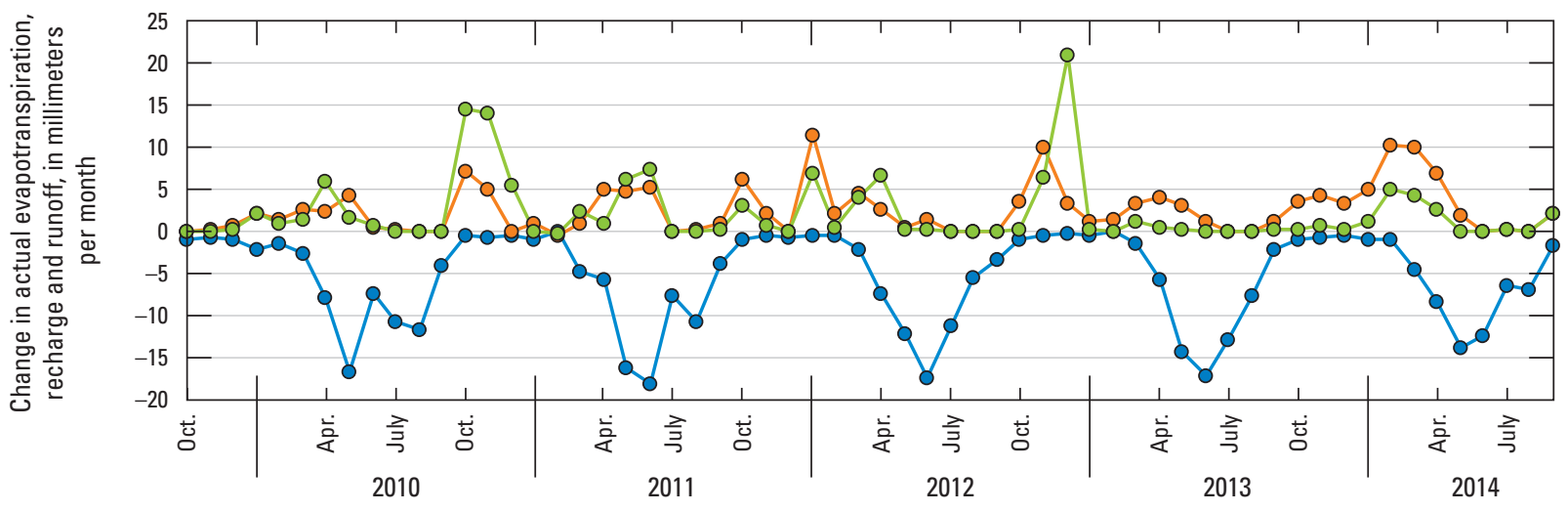

EXPLANATION

Forest die-off

- Actual evapotranspiration $\quad-0$ - Recharge Runoff

C

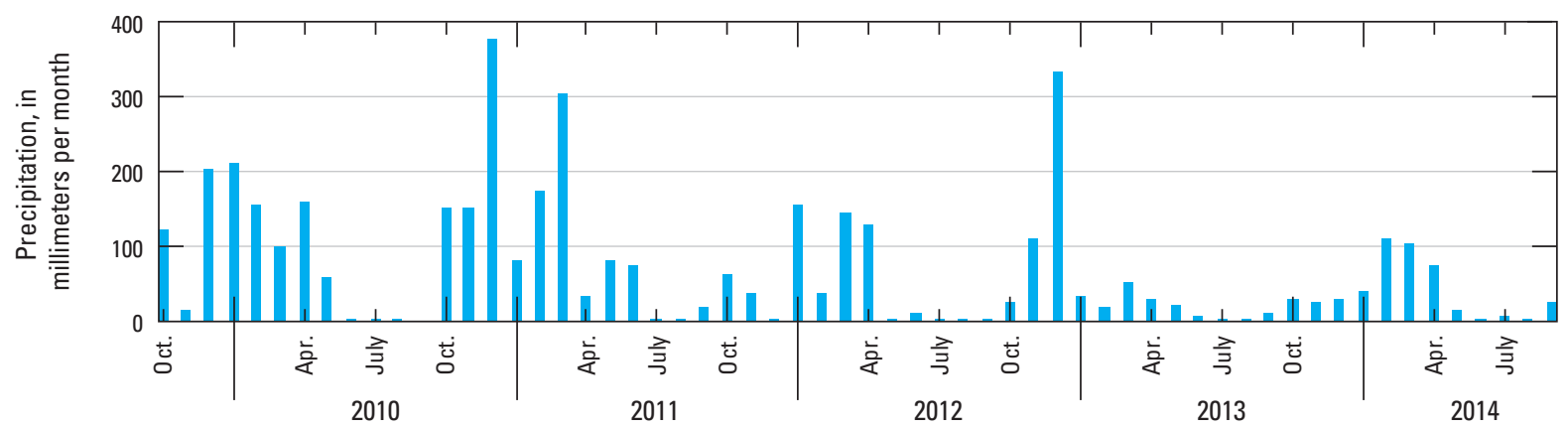

Figure 27. Simulations of actual evapotranspiration, recharge, and runoff in the Merced River basin, California, water years 2010-14, $A$, with baseline vegetation and $B$, the change from baseline conditions after forest die-off; using $C$, measured precipitation from water years 2010-14. 
$\boldsymbol{A}$

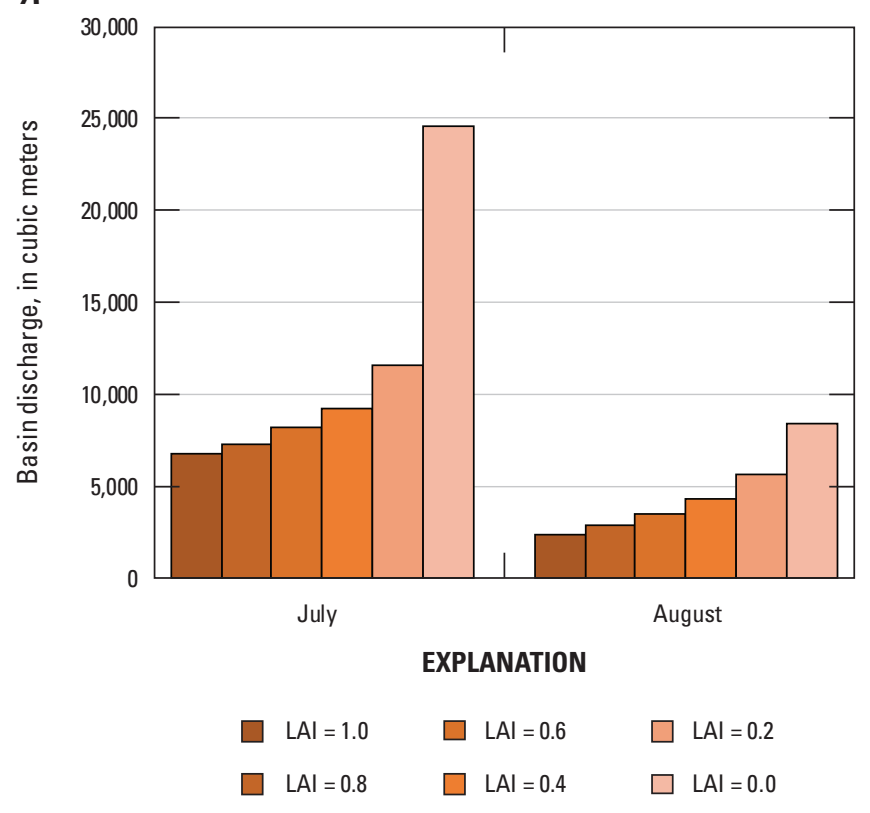

B

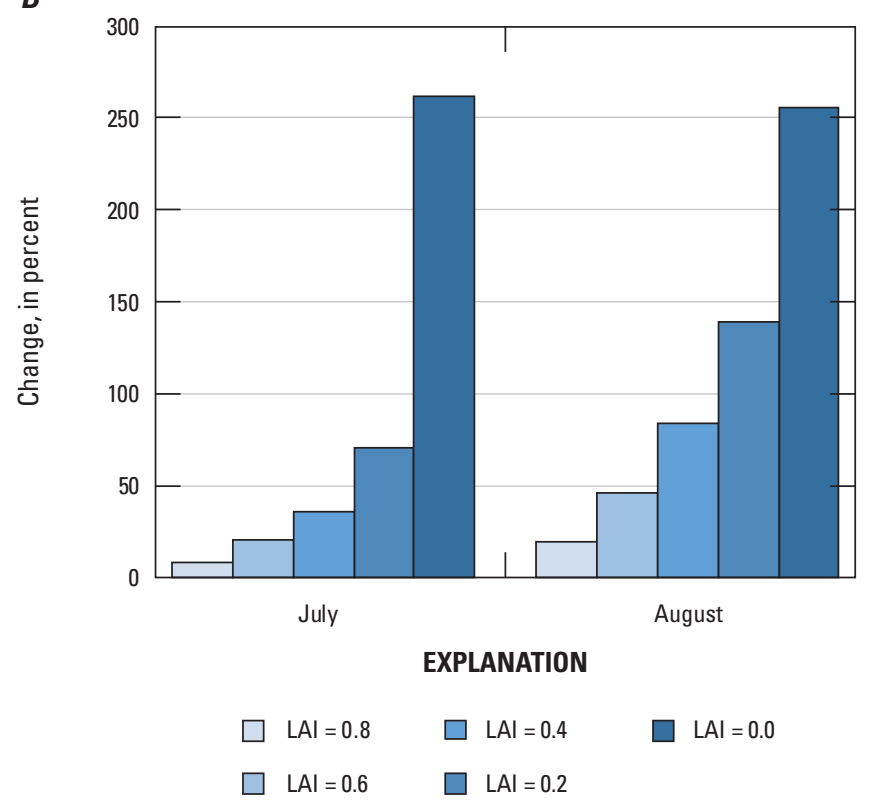

Figure 28. Effects of forest management by leaf area index (LAI) or density in the Mad River basin, California, $A$, on late-summer basin discharge, and $B$, as a percentage of change from baseline (full LAI) late-summer basin discharge.

\section{Application 4: Effects of Soil Management on Recharge, Climatic Water Deficit, and Forage Production}

Ongoing changes in climate and increases in water use have led to strategic soil management throughout California and elsewhere to improve soil health and increase soil water-holding capacity. Scientific studies have shown that managing farms, ranches, and public lands to increase soil carbon can increase soil water-holding capacity and increase hydrologic benefits such as increased base flows and aquifer recharge, reduced flooding and erosion, and reduced climate-related water deficits (van Mantgem and others, 2013; Muñoz-Rojas and others, 2016; Flint and others, 2018). Coincident improvements in forage and crop yields are also indicated, while simultaneously sequestering carbon, reducing atmospheric greenhouse gases and mitigating climate change. This BCMv8 application used an example of increasing the soil organic matter (SOM) component in the calculations to provide soil hydraulic properties' (FIELD CAPACITY, WILTING POINT, POROSITY) layers for input to the BCMv8 and then illustrated the effects on the resulting hydrologic output.

For this example, the BCMv8 was run for California for 1981-2010, as described in Flint and others (2018). The soil input layers were developed using the model code "SoilProps," which is described in the "Developing a New BCMv8" section, to calculate the three soil hydraulic properties from soil-texture GIS layers for percentages of sand, silt, and clay; bulk density; porosity; and SOM. SoilProps processes the geospatial data using equations developed by Saxton and Rawls (2006), who evaluated the relation among SOM, porosity, field capacity, and wilting point on the basis of thousands of laboratory-analyzed field samples (fig. 29). This figure illustrates the soil water-holding capacity (WHC), defined as the difference between field capacity at $-0.01 \mathrm{MPa}$ and wilting point at $-6 \mathrm{MPa}$, for different amounts of SOM. The increase in WHC differed by textural class: the largest increases were in silty loam and loamy fine sand, and the smallest increases were in silty clay loam and sandy loam. Clay soils (silty clay and clay textural classes) did not benefit from addition of SOM, and the calculations indicated reduced WHC with the addition of SOM. This is often because the wilting point increases more than field capacity, thus reducing the WHC. This application example used an increase in SOM of 3 percent greater than that defined in the SOM layer available from SSURGO (https://websoilsurvey.nrcs.usda.gov/). The BCMv8 was run for 1981-2010, and calculations were done only for those vegetation types considered working lands, that is, annual grasslands, croplands, and shrublands; thus, the MASK switch was on, and the mask file was developed for all vegetation types that were not considered working lands. 


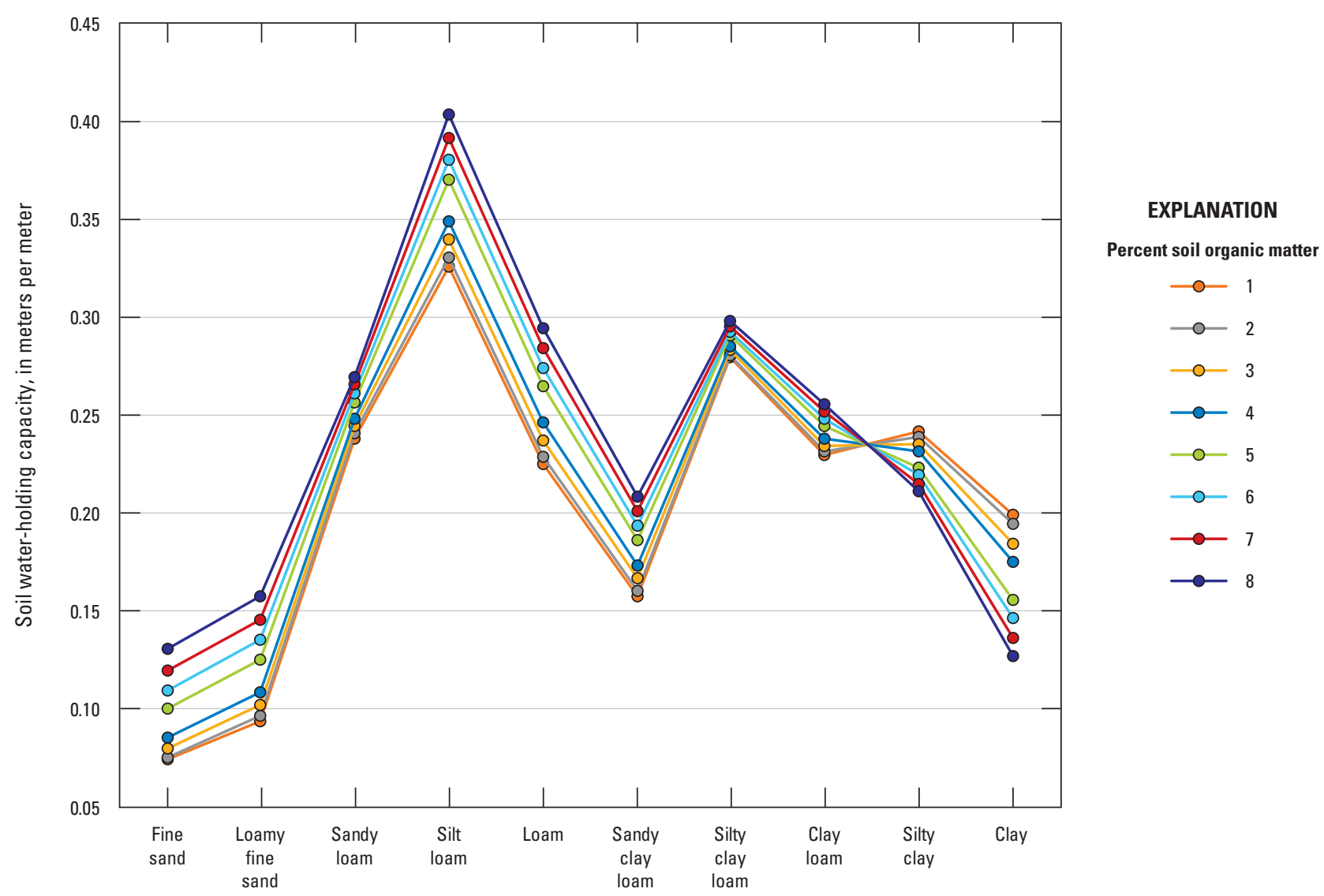

Figure 29. Soil water-holding capacity for different soil textural classes at different percentages of soil organic matter (SOM) based on equations developed by Saxton and Rawls (2006).

The BCMv8 results are shown for three counties. Change in recharge resulting from SOM addition, calculated as a difference from baseline soils (without the addition of 3 percent SOM), is shown in figure $30 \mathrm{~A}$. There are very few locations in Tehama County where recharge was reduced as a result of the addition of SOM; at most locations, recharge increased from 5 to $30 \mathrm{~mm} /$ year. Climatic water deficit decreased for all working lands in Santa Barbara County (fig. $30 B$ ) by as much as $30 \mathrm{~mm} /$ year when the $\mathrm{SOM}$ addition was simulated. This variable is an indication of a reduction in landscape stress that can be considered a direct reduction in irrigation demand. The AET has been shown to correlate well with production of forage on grasslands (Flint and others, 2018). When SOM was added in Tulare County (fig. 30C), simulated AET increased only slightly on the valley floor, where the precipitation is low, but increased by up to $40 \mathrm{~mm} / \mathrm{year}$ in the adjacent foothills. 

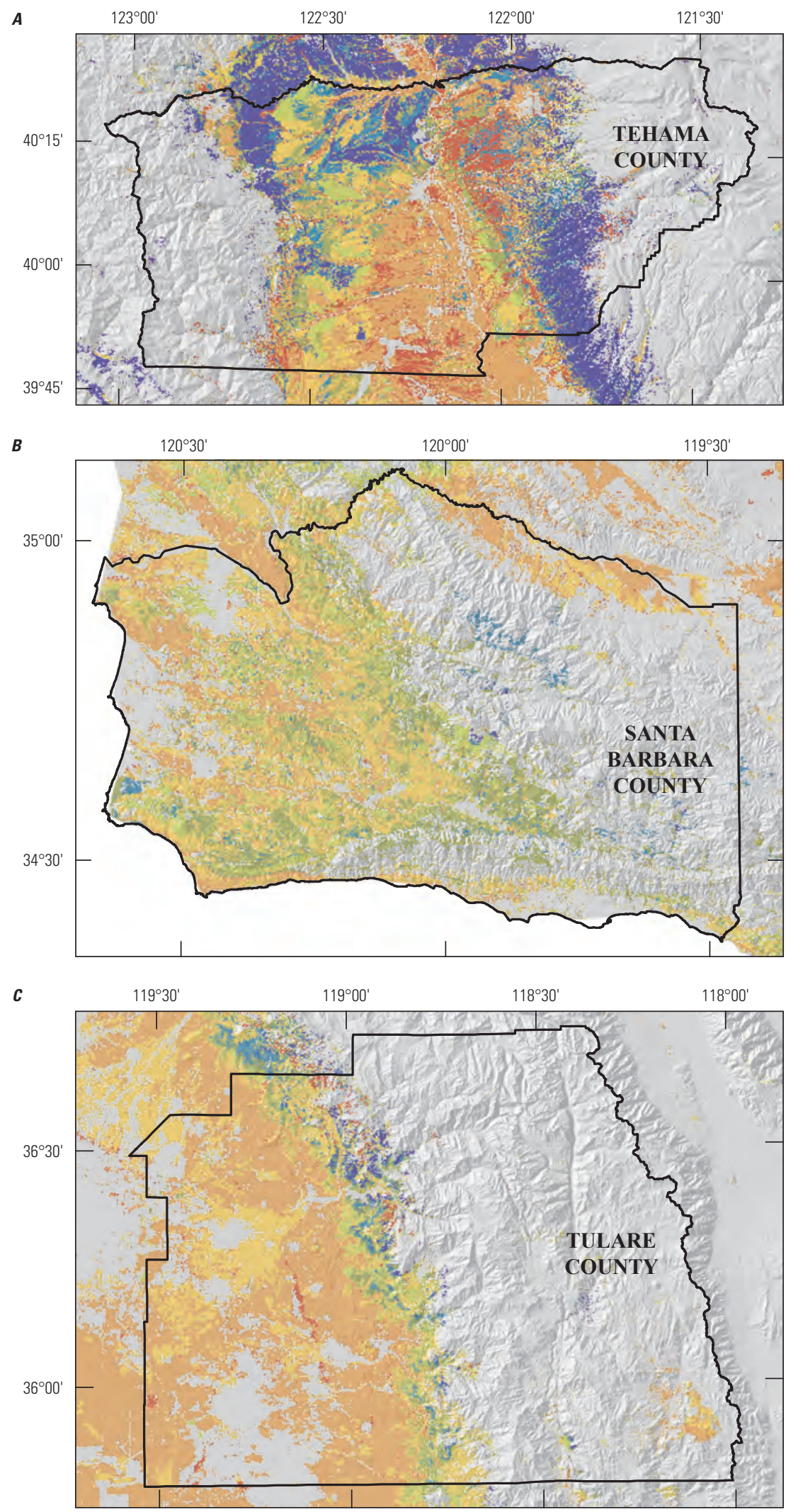

EXPLANATION

Recharge (difference from baseline), in millimeters per year
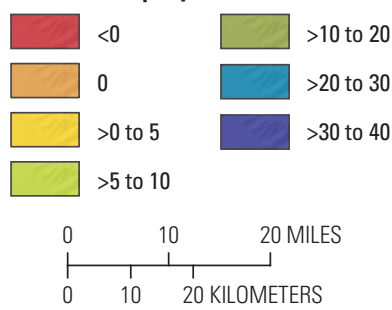

Base modified from U.S. Geological Survey digital data, various scales; Albers Equal Area Conic projection, standard parallels are $29^{\circ} 30^{\prime \prime}$ and 4530"; North American Datum of 1983

\section{EXPLANATION}

Climatic water deficit (difference from baseline), in millimeters per year

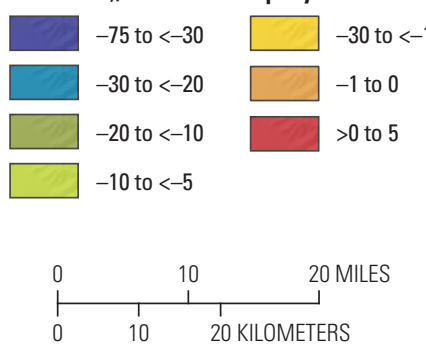

Base modified from U.S. Geological Survey digital data, various scales; Albers Equal Area Conic projection, standard parallels are $29^{\circ} 30^{\prime \prime}$ and 4530"; North American Datum of 1983

\section{EXPLANATION}

Actual evapotranspiration (difference from baseline), in millimeters per year
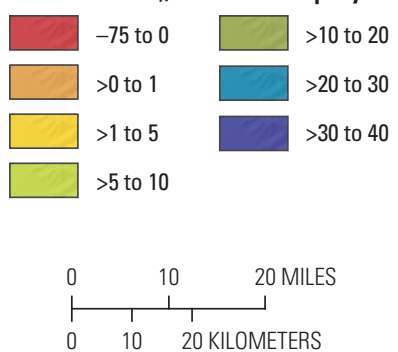

Base modified from U.S. Geological Survey digital data, various scales; Albers Equal Area Conic projection, standard parallels are $29^{\circ} 30^{\prime \prime}$ and 4530"; North American Datum of 1983

Figure 30. Changes as a result of increasing soil organic matter by 3 percent for 1981-2010 in all soils collocated with vegetation types classified as annual grasslands, croplands, or shrublands to modeled $A$, recharge in Tehama County; $B$, climatic water deficit in Santa Barbara County; and $C$, actual evapotranspiration in Tulare County. Gray background corresponds to cells with no mapped working lands and no calculations made. 


\section{Application 5: Applying Future Climate Projections to Evaluate Water Availability}

Future climate projections can easily be prepared and applied to the BCMv8 to evaluate projected changes in water availability, species' movements, refugia, fire risk, irrigation demand, and other hydrologic assessments. Projections of climate conditions are available from many sources (for example, WorldClim: https://www.worldclim.org, Coupled Model Intercomparison Project, Phase 5 (CMIP5: https://esgf-node.llnl.gov/projects/esgf-llnl/). Each of these studies has data that have been statistically downscaled from the global scale using specific methodologies. Several of these datasets have been spatially downscaled for BCMv8 application using the method described in procedure 1 (appendix 2, section "Developing Climate Grids"; Flint and Flint, 2012; LOCA 4th California assessment, 18 California futures website, https://ca.water.usgs.gov/projects/reg_hydro/ basin-characterization-model.html). Data obtained are initially reprojected to local coordinates in feet or meters, then put through a series of spatial downscaling steps depending on the initial grid size, to yield files that exactly match the extent and resolution of the DEM of the local fine-scale model. The PET is then calculated from the air-temperature data following methods detailed in the appendix 2 section "Developing Potential Evapotranspiration."

This example application focuses on the Russian River basin in northern California and uses climate projections from the 18 California futures website. The example explores a variety of approaches to represent future climate conditions for several water-availability metrics.

Water for the Russian River basin is primarily supplied by surface-water flow from the Russian River that is stored in two reservoirs. Additional supplies include well fields at several locations providing groundwater to supplement agricultural uses. Several of the cities in the basin are prone to flooding, and droughts are a consistent concern given the prominent role agriculture plays in the basin and the expanding area of urbanization. The first example problem assesses how extremes in the hydrologic record are projected to change. Six future climate models were considered, one from a mitigated scenario (scenario 1) and five from business-as-usual emissions scenarios (scenarios 2-6, table 10). Once applied to the Russian River using a basin file that defined the basin boundary, the water year outfile was used to assess changes in rainfall for the historical period (1920-2009) and for the six future projections (2010-99). The historical maximum annual total rain fell during 1940 and was 69.1 inches (in.), but during the historical drought year 1976, the total rainfall was 15.9 in. Exceedance plots were calculated for each of the projected time series, and the values of precipitation for both the maximum and minimum historical years and the 10th and 90th percentiles of the historical record were compared with those from each of the future projections. This comparison shows that if an average was taken across the six projected futures, annual high rainfall years (defined as exceeding the 90th percentile value of the 1920-2009 period) and low rainfall years (defined as less than the 10th percentile value of the 1920-2009 period) were projected to increase on the order of 136 percent and 65 percent, respectively. Moreover, the "worst case scenarios" represented by the highest and lowest precipitation values for single historical years corresponded to greater increases in the values of extreme events. For example, under the warm and high rainfall scenario, an 850-percent increase in high flood-risk years was projected, whereas under low rainfall scenarios, extreme drought years were projected to double.

Table 10. Change in frequency of annual rainfall extremes per decade for the Russian River basin, California, from the historical period (1920-2009) in comparison to six climate change projections for 2010-99.

$[\geq$, greater than or equal to; >, greater than; $\%$, percent; $<$, less than; $\leq$, less than or equal to; in $/$ yr, inch per year]

\begin{tabular}{|c|c|c|c|c|c|}
\hline $\begin{array}{c}\text { Scenario } \\
\text { number }\end{array}$ & Model description & $\begin{array}{c}\geq 69.1 \mathrm{in} / \mathrm{yr} \\
\quad(1940)\end{array}$ & $\begin{array}{c}>90 \text { th \% } \\
(56.4 \mathrm{in} / \mathrm{yr})\end{array}$ & $\begin{array}{c}<10 \text { th \% } \\
(27.1 \mathrm{in} / \mathrm{yr})\end{array}$ & $\begin{array}{c}\leq 15.9 \mathrm{in} / \mathrm{yr} \\
(1976)\end{array}$ \\
\hline \multicolumn{6}{|c|}{ Percent change from historical per decade } \\
\hline 1 & Low warming, low rainfall & 150 & 44 & 100 & -100 \\
\hline 2 & Low warming, moderate rainfall & 200 & 156 & 89 & 200 \\
\hline 3 & Warm, moderate rainfall & 150 & 111 & 11 & -100 \\
\hline 4 & Warm, low rainfall & 50 & 11 & 156 & 200 \\
\hline 5 & Warm, high rainfall & 850 & 356 & -33 & -100 \\
\hline \multirow[t]{2}{*}{6} & Hot, low rainfall & -100 & -56 & 56 & 0 \\
\hline & Average & 280 & 136 & 65 & 20 \\
\hline
\end{tabular}


Whether climate conditions result in recharge or runoff is of interest to many water managers because the relation between these two processes informs the dominant type of infrastructure that is required to support surface-water or groundwater supplies. The annual values for recharge and runoff were calculated for the Russian River basin for the "warmer and moderately increased rainfall" projection (scenario 3, table 10). Results (shown in acre-feet/year in fig. 31) illustrate that for this scenario recharge increased only slightly, whereas runoff increased by 16 percent. The difference in change between recharge and runoff indicates a greater resiliency of recharge to the simulated climate-change scenarios; that is, within the range of projected future conditions, recharge did not change as much as runoff, and in wet years, runoff often greatly exceeded recharge in this basin. The conceptual understanding of these water-balance projections can help to inform managers how to plan best for future changes in the dynamics of their water supply.
Results of future climate-scenario analyses can also be represented spatially using maps to show where hydrologic conditions in the basin are more or less likely to change in the future. For example, consider recharge for the upper Russian River basin where two groundwater basins, the Ukiah Valley and Potter Valley, are prominent resources (fig. 32A). For 1981-2010, the 30-year average annual recharge, represented as a spatial distribution, varies from 2.5 to 30 inches/yr. Three future scenarios were considered to explore a range of rainfall conditions, and the values for the groundwater subbasins (table 11) showed a range of future recharge conditions for the scenarios. The maps (fig. $32 B-D$ ) indicate that the groundwater basins are sensitive to future changes in climate, whereas the mountain sources of recharge to the west of the basins consistently maintained recharge, typically at more than 20 inches per year.

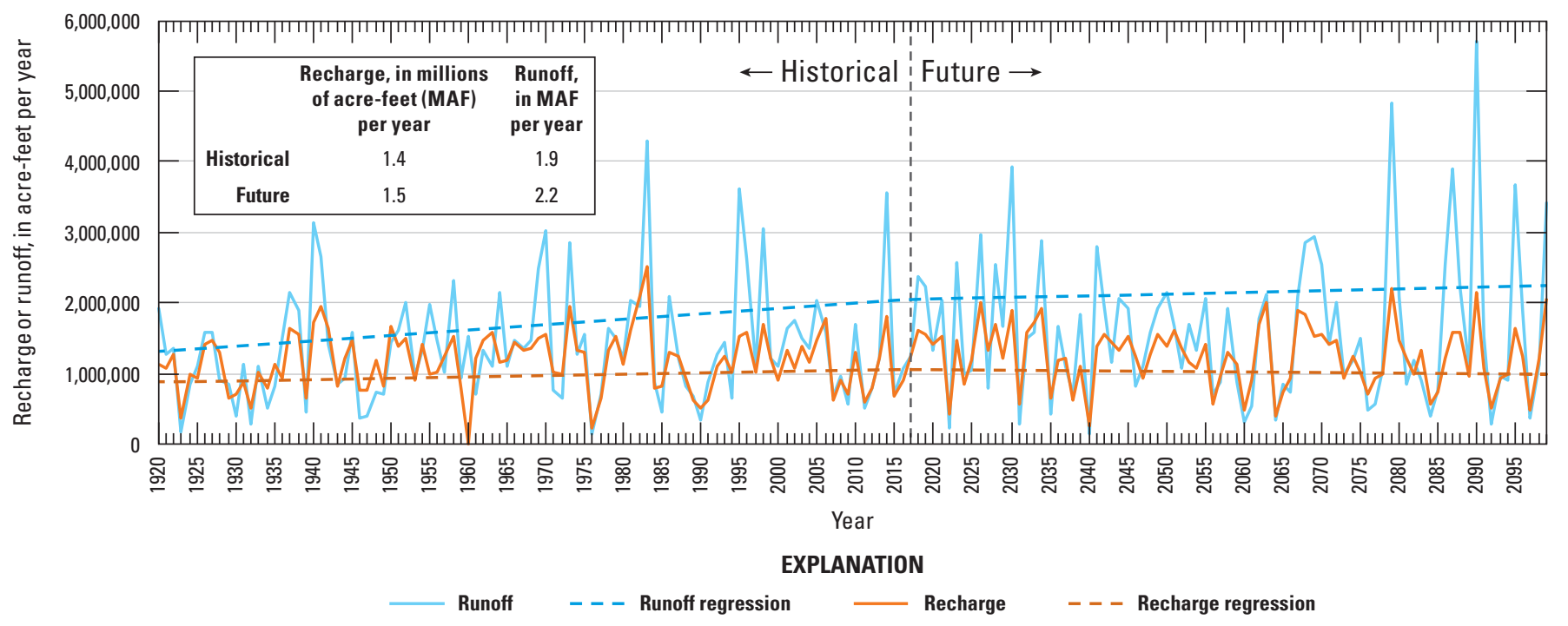

Figure 31. Annual recharge and runoff calculated using the BCMv8 for the Russian River basin for 1920-2017 and for a future climate scenario representing a warmer climate with moderately increased rainfall (CCSM4, rcp8.5).

Table 11. Recharge estimates for water years 1981-2010 and BCMv8-projected future changes in recharge for 2070-99 under three future climate scenarios in two groundwater subbasins in the upper Russian River basin, Mendocino County, California.

\begin{tabular}{lcccc}
\hline Subbasin & $\begin{array}{c}\text { Recharge } \\
\mathbf{1 9 8 1 - 2 0 1 0}\end{array}$ & \multicolumn{3}{c}{ Future, 2070-99 (percent change) } \\
\cline { 3 - 5 } & (inches per year) & $\begin{array}{c}\text { Warm, high } \\
\text { rainfall }\end{array}$ & $\begin{array}{c}\text { Warm, moderate } \\
\text { rainfall }\end{array}$ & $\begin{array}{c}\text { Hot, } \\
\text { low rainfall }\end{array}$ \\
\hline Ukiah Valley & 36.1 & 22 & 0 & -16 \\
East Fork Potter Valley & 15.7 & 15 & -1 & -14 \\
\hline
\end{tabular}


A

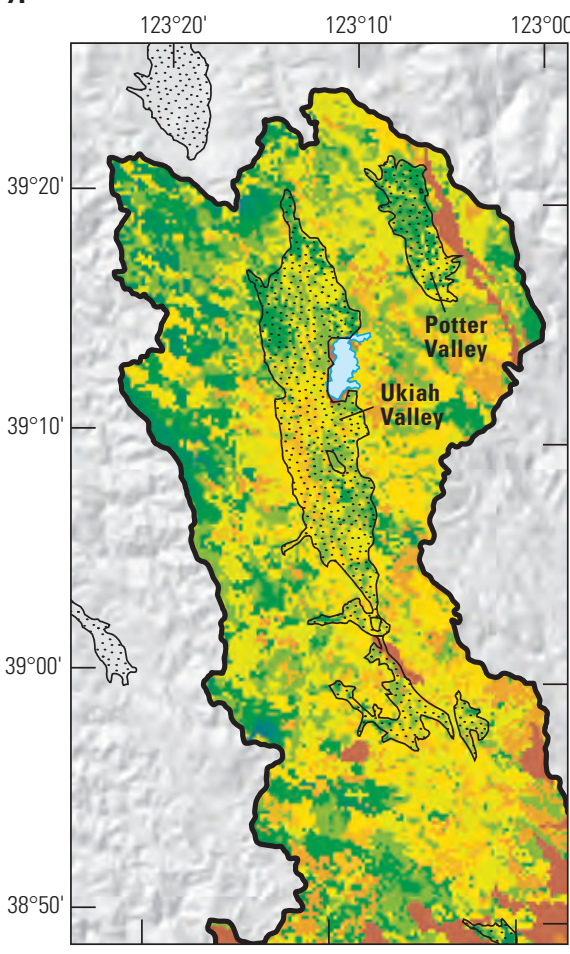

Base modified from U.S. Geological Survey digital data, various scales; Albers Equal Area Conic projection, standard parallels

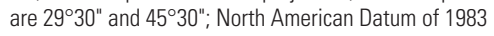

C

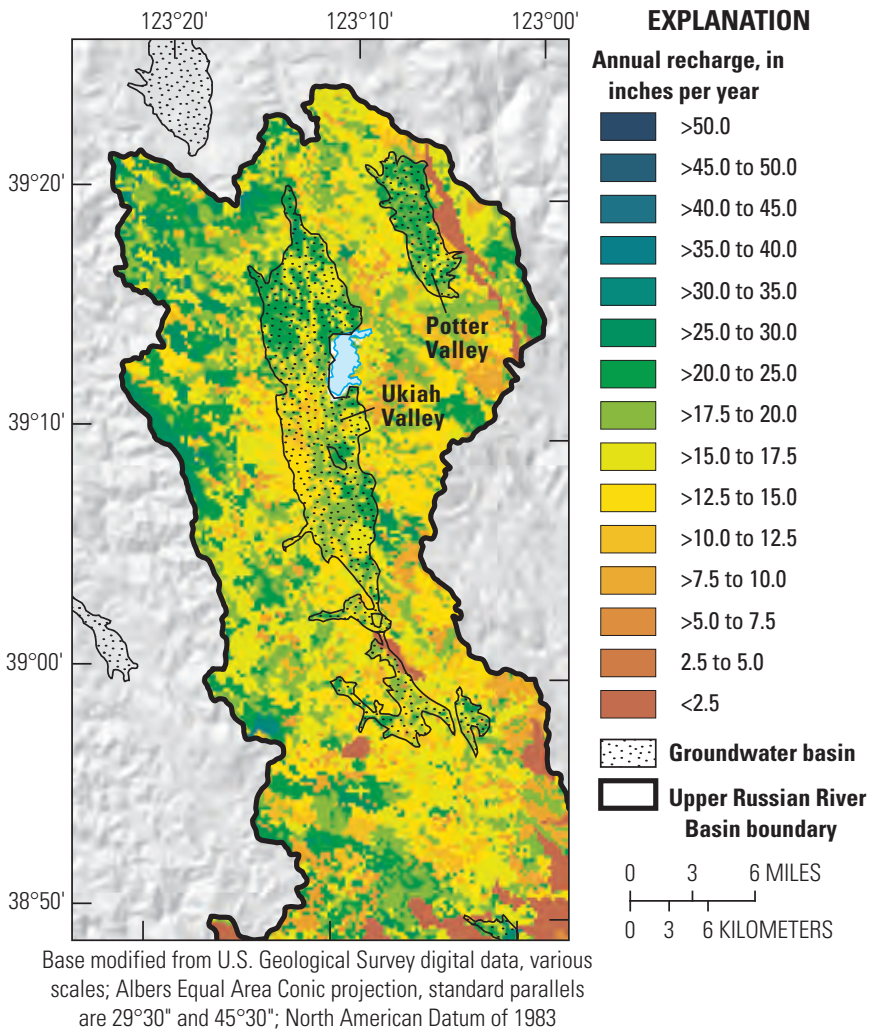
Annul inches per year $>50.0$

$>45.0$ to 50.0

$>40.0$ to 45.0

$>35.0$ to 40.0

$>30.0$ to 35.0

$>25.0$ to 30.0

$>20.0$ to 25.0

$>17.5$ to 20.0

$>15.0$ to 17.5

$>12.5$ to 15.0

$>10.0$ to 12.5

$>7.5$ to 10.0

$>5.0$ to 7.5

2.5 to 5.0

$<2.5$

Groundwater basin

Upper Russian River Basin boundary

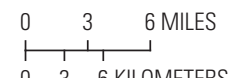

$\begin{array}{lll}0 & 3 & 6 \text { KILOMETERS }\end{array}$
B

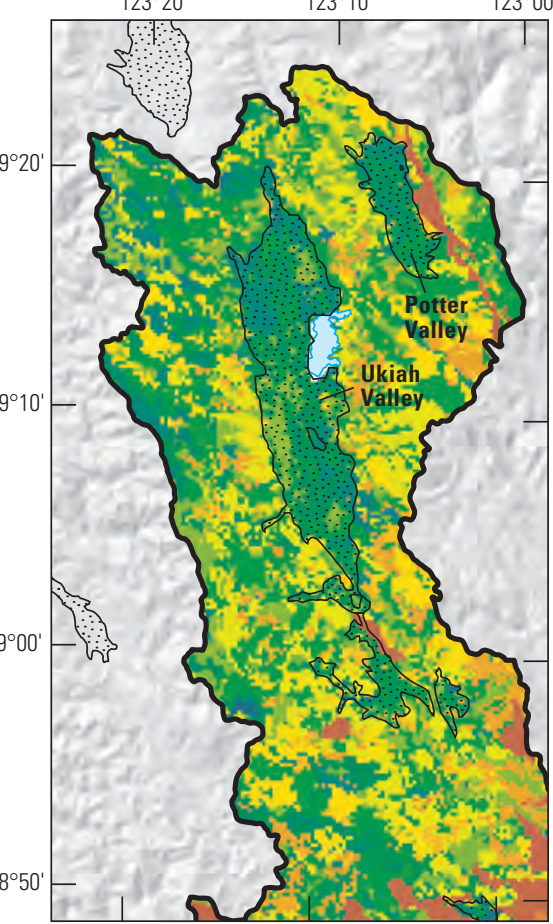

$123^{\circ} 00^{\circ}$

EXPLANATION

Annual recharge, in

inches per year

$>50.0$

$>45.0$ to 50.0

$>40.0$ to 45.0

$>35.0$ to 40.0

$>30.0$ to 35.0

$>25.0$ to 30.0

D $>20.0$ to 25.0

$>17.5$ to 20.0

$>15.0$ to 17.5

$>12.5$ to 15.0

$>10.0$ to 12.5

$>7.5$ to 10.0

$>5.0$ to 7.5

2.5 to 5.0

$<2.5$

Groundwater basin

Upper Russian River Basin boundary

$\begin{array}{lll}0 & 3 & 6 \text { MLLES }\end{array}$

$\begin{array}{lll}0 & 3 & 6 \text { KILOMETERS }\end{array}$

Base modified from U.S. Geological Survey digital data, various scales; Albers Equal Area Conic projection, standard parallels are $29^{\circ} 30^{\prime \prime}$ and $45^{\circ} 30^{\prime \prime}$; North American Datum of 1983

D

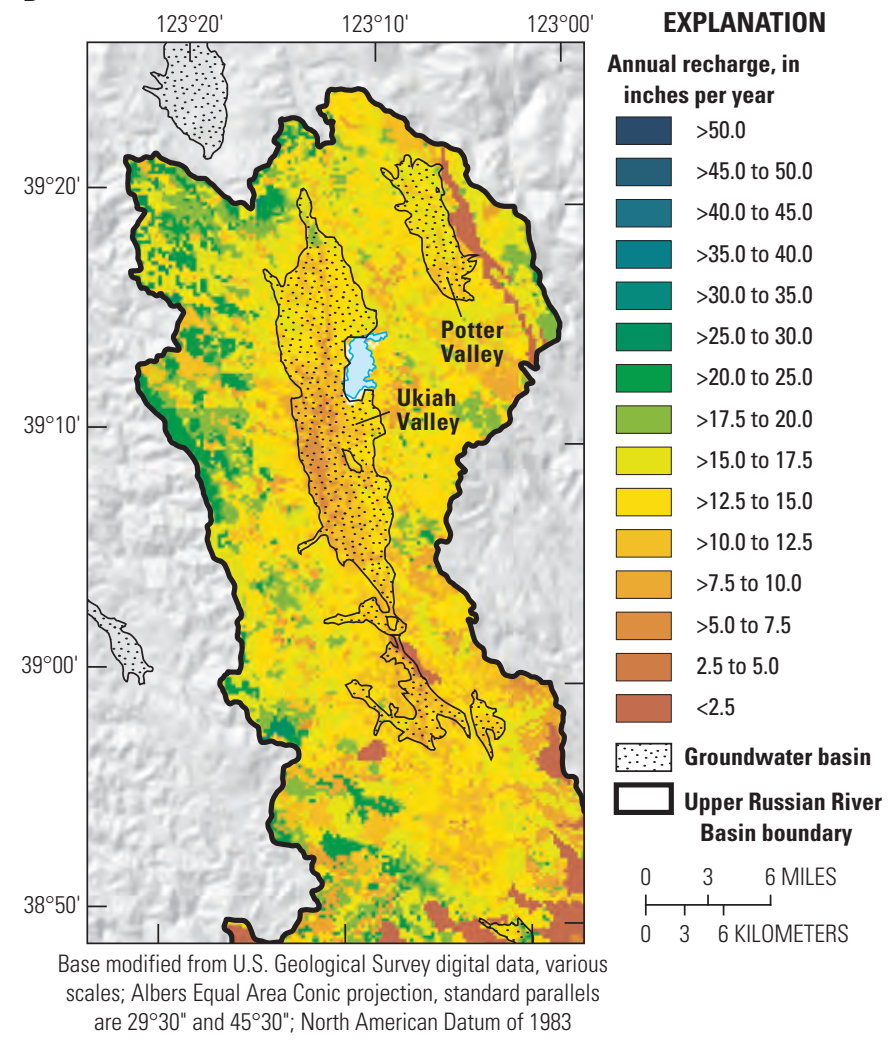

Figure 32. Average annual recharge for subbasins in the upper Russian River basin, Mendocino County, California, under climates projected by the BCMv8 for $A, 1981-2010 ; B, 2070-99$, warm with high rainfall; $C$, 2070-99, warm with moderate rainfall; $D, 2070-99$, hot with low rainfall. Future climate scenarios $(B$ to $D)$ are listed in table 10 as scenarios 5,3 , and 6 , respectively. 


\section{Application 6: Implementing Managed Aquifer Recharge}

Sustainability of groundwater resources may require site-specific management of water to increase groundwater recharge. This can be applied by artificially imposing flooded or ponded conditions when surface water is available for delivery to create a constant supply of water for recharge (Flint and Ellett, 2004; Izbicki and others, 2008). The resulting amount of recharge is then limited by the saturated hydraulic conductivity of the soil profile or the underlying geologic conductivity, whichever is the lowest. Agricultural flooding is often used for production of crops such as rice (where soils have low conductivity to more easily maintain flooded conditions), which also improves wildlife habitat by extending the time when flooded conditions coincide with presence of waterfowl. Recently, some producers have used flooding of fallow fields or orchards during periods when surface water is readily available to increase recharge to replenish groundwater for irrigation wells pumped during the dry season.

This model application was intended to provide the BCMv8 user with an opportunity to test imposing flooded or ponded conditions for a specified number of months per year to assess if recharge increased relative to recharge under natural conditions, disregarding baseline agricultural management.

The FLOOD maps were prepared for months when flooded conditions were observed. In this example, we imposed flooded conditions representative of a California rice field corresponding to LANDSAT observations averaged for 2000-13. We imposed additional flooded conditions to the rice field, which typically is dry during August and September, when there is no rain and therefore no recharge, to assess any benefits of managed aquifer recharge. The seasonal flooding of the rice field is discontinued in June for harvesting and to allow the soils to drain prior to imposing additional managed aquifer-recharge water. The switch for FLOOD is set to 1, and the name of the files are noted in the control file. In this example we ran the model for a year, water year 2010, that had average precipitation, sufficient to allow the soil profile to fill in August under the extended-flooded conditions and maximum recharge in September, constrained by the soil K. Results indicated about 5,800 acre-feet of natural recharge (with no flooding), which is about 24,000 acres, for water year 2010 (figs. 33A, 34), whereas under traditionally managed agricultural practices, which include flooding for rice for about 4 months in the winter and again in May, recharge exceeded 700,000 acre-feet/year (figs. 33B, 34). If extended flooding was imposed during the dry season in August and September, recharge could be increased by another 320,000 acre-feet (fig. $33 \mathrm{C}$ ). These values assumed 1-meter depth of standing water, which in comparison to measured deliveries to this region are approximately 4 times too high given the mapped soil texture and associated estimates of Ksat. If physical measurements of Ksat or GeolK are available for your study area, use the locally derived values in the input grid or table. 
$\boldsymbol{A}$

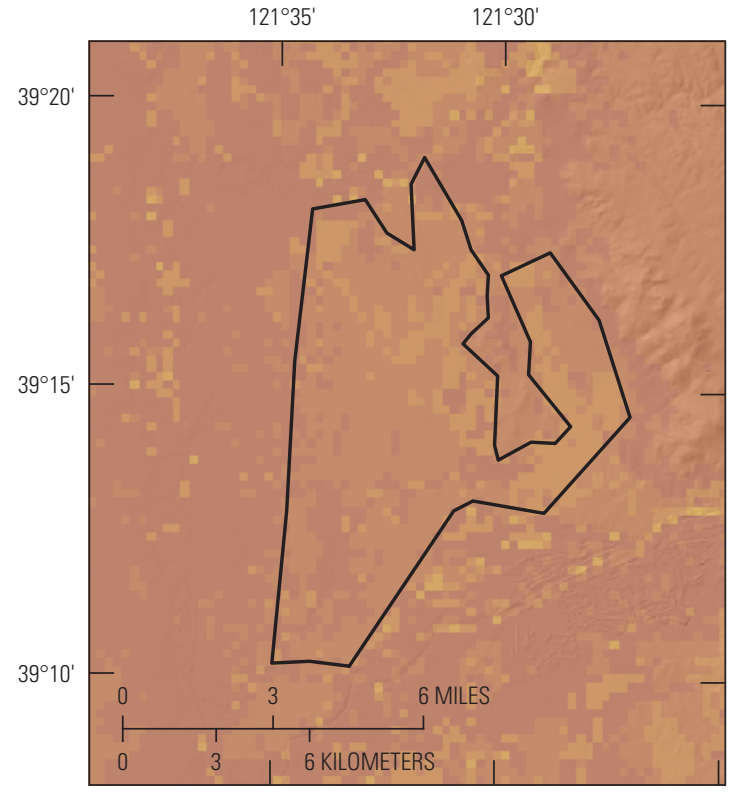

Base modified from U.S. Geological Survey digital data, various scales; Albers Equal Area Conic projection, standard parallels are $29^{\circ} 30^{\prime \prime}$ and 4530"; North American Datum of 1983

\section{EXPLANATION}

Flood boundary

Recharge, in millimeters per year

\begin{tabular}{|c|c|c|}
\hline 0 to 50 & $>500$ to 800 & $>2,000$ to 5,000 \\
\hline$>50$ to 100 & $>800$ to 1,000 & $>5,000$ to 10,000 \\
\hline$>100$ to 200 & $>1,000$ to 1,200 & $>10,000$ to 20,000 \\
\hline$>200$ to 400 & $>1,200$ to 1,500 & $>20,000$ to 30,00 \\
\hline$>400$ to 500 & $>1,500$ to 2,000 & $>30,000$ \\
\hline
\end{tabular}

C

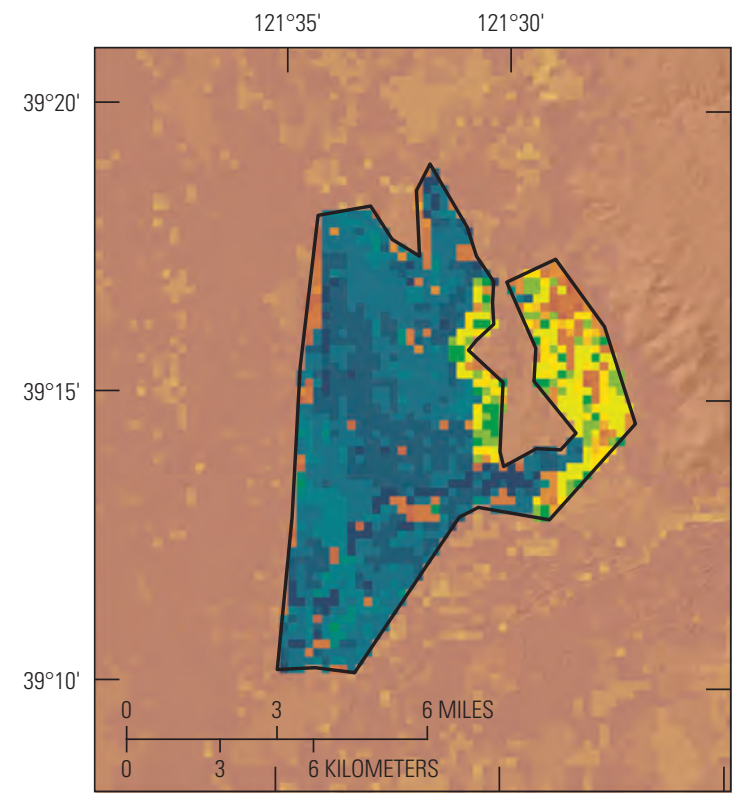

Base modified from U.S. Geological Survey digital data, various scales; Albers Equal Area Conic projection, standard parallels are $29^{\circ} 30^{\prime \prime}$ and 4530"; North American Datum of 1983
B

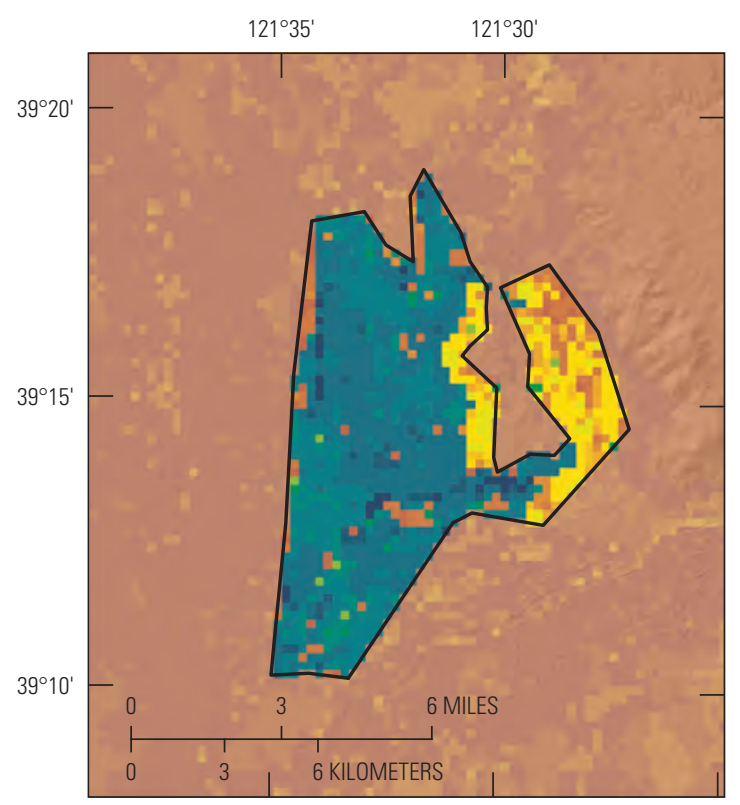

Base modified from U.S. Geological Survey digital data, various scales; Albers Equal Area Conic projection, standard parallels are 29 $20^{\circ}$ and 45³0"; North American Datum of 1983

\section{EXPLANATION}

Flood boundary

Recharge, in millimeters per year

\begin{tabular}{|c|c|c|}
\hline 0 to 50 & $>500$ to 800 & $>2,000$ to 5,000 \\
\hline$>50$ to 100 & $>800$ to 1,000 & $>5,000$ to 10,000 \\
\hline$>100$ to 200 & $>1,000$ to 1,200 & $>10,000$ to 20,000 \\
\hline$>200$ to 400 & $>1,200$ to 1,500 & $>20,000$ to 30,000 \\
\hline$>400$ to 500 & $>1,500$ to 2,000 & $>30,000$ \\
\hline
\end{tabular}

\section{EXPLANATION}

Flood boundary

Recharge, in millimeters per year

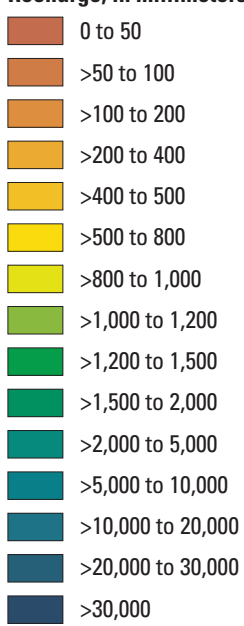

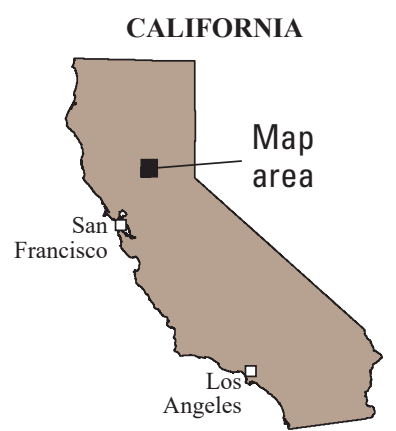

Figure 33. California rice-field example showing annual recharge for water year 2010 representing simulations of $A$, natural conditions with no managed flooding; $B$, traditionally managed seasonal flooding for rice; and $C$, extended managed-recharge scenario with traditional flooding plus additional flooding in August and September. 


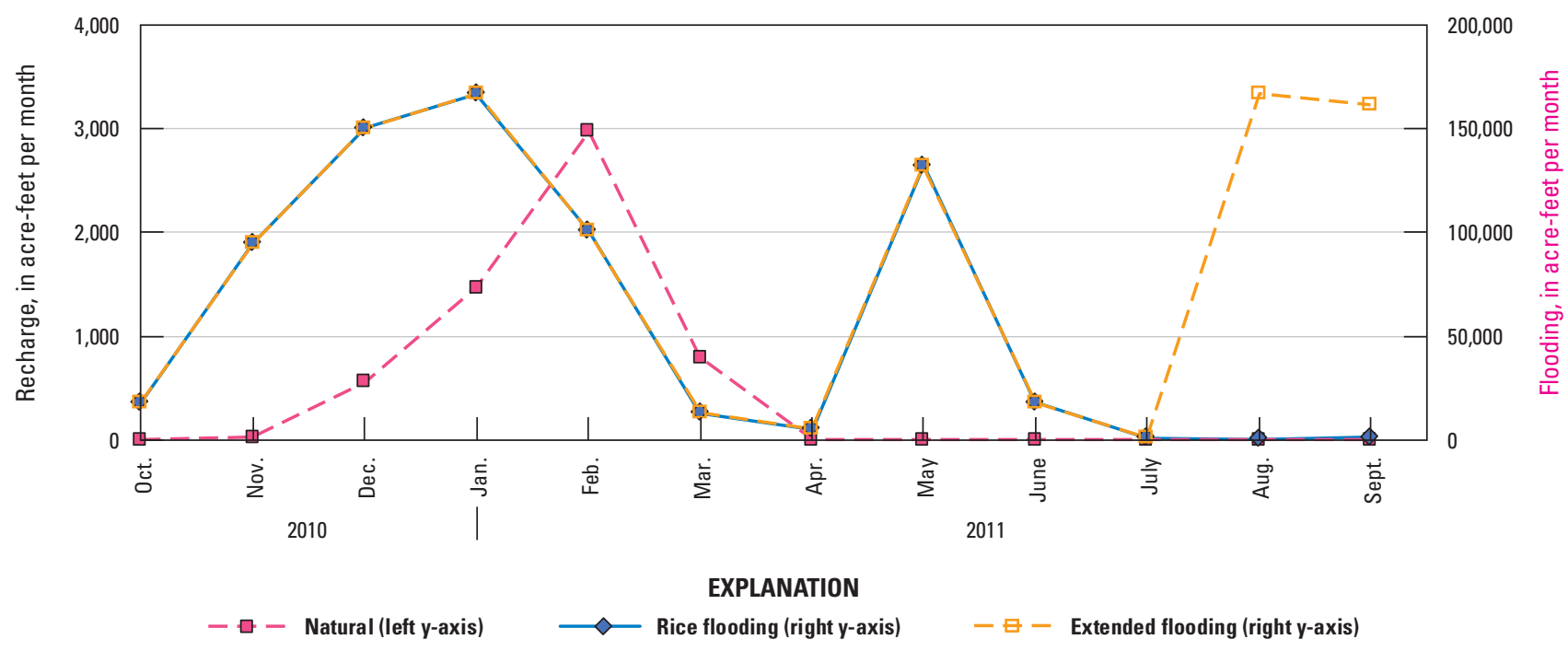

Figure 34. Monthly time series of recharge for rice field under natural conditions with no managed flooding, managed seasonal flooding of rice, and additional flooding in August and September, water year 2010, California.

\section{Application 7: Applying BCMv8 Boundary Conditions to Groundwater-Flow Models}

Recharge and runoff boundary conditions are necessary for groundwater-flow models and have been developed using the BCMv8 for many basins in California and the western United States. An example is shown for the Cuyama Valley (Hanson and others, 2014b) in the central coast region of California (fig. 35). A basin file was developed to span streamflow measurements representing a range of geologic types. The BCMv8 was run and calibrated to optimize the match between observed and simulated streamflow. Then, new basin files were developed to represent the points at which the groundwater modeler requires time-series inputs for recharge or runoff. In this example, figure 36 shows the points and upstream basin areas that were used to develop a time series for recharge that was input to a subsurface model layer for the model grid shown in figure $36 \mathrm{~A}$ and for runoff that was input to the MODFLOW SFR streamflow-routing package shown by figure $36 B$.

This application can also be used for future climate simulations as was done with MODFLOW-OWHM for the Central Valley of California (Hanson and others, 2012), and input to the Farm Process in OWHM to drive supply and irrigation demand, and as future inflows from surrounding watersheds for simulation of potential surface-water supplies also needed for irrigation, ecological streamflows, and habitat maintenance. 
A

$34^{\circ} 45^{\prime}$

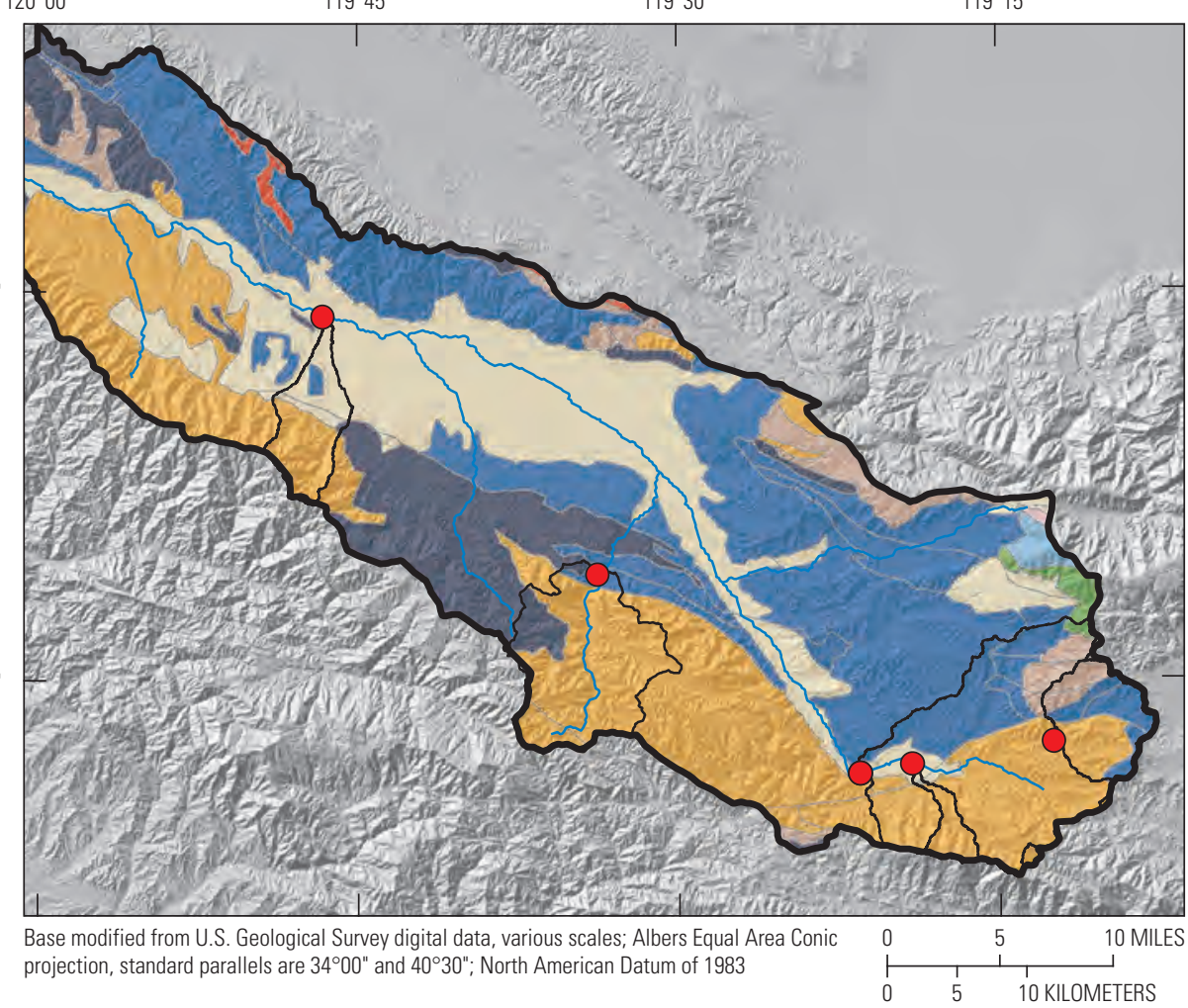

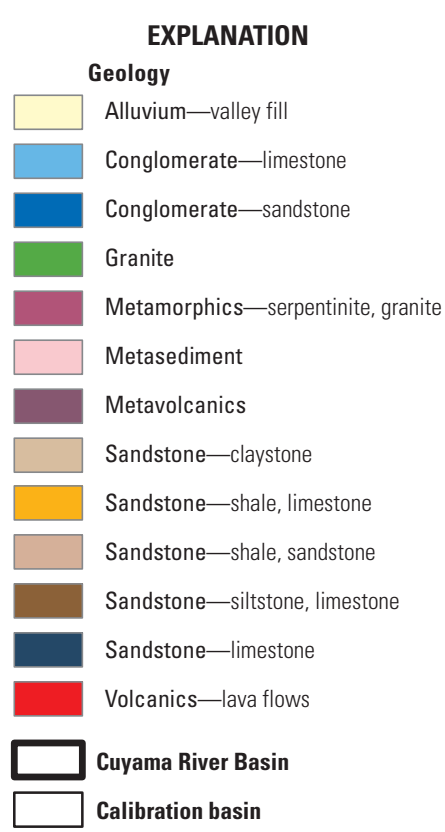

Calibration streamgage

B $120^{\circ} 00^{\prime}$ $119^{\circ} 45^{\prime}$ $119^{\circ} 30^{\prime}$ $119^{\circ} 15^{\prime}$

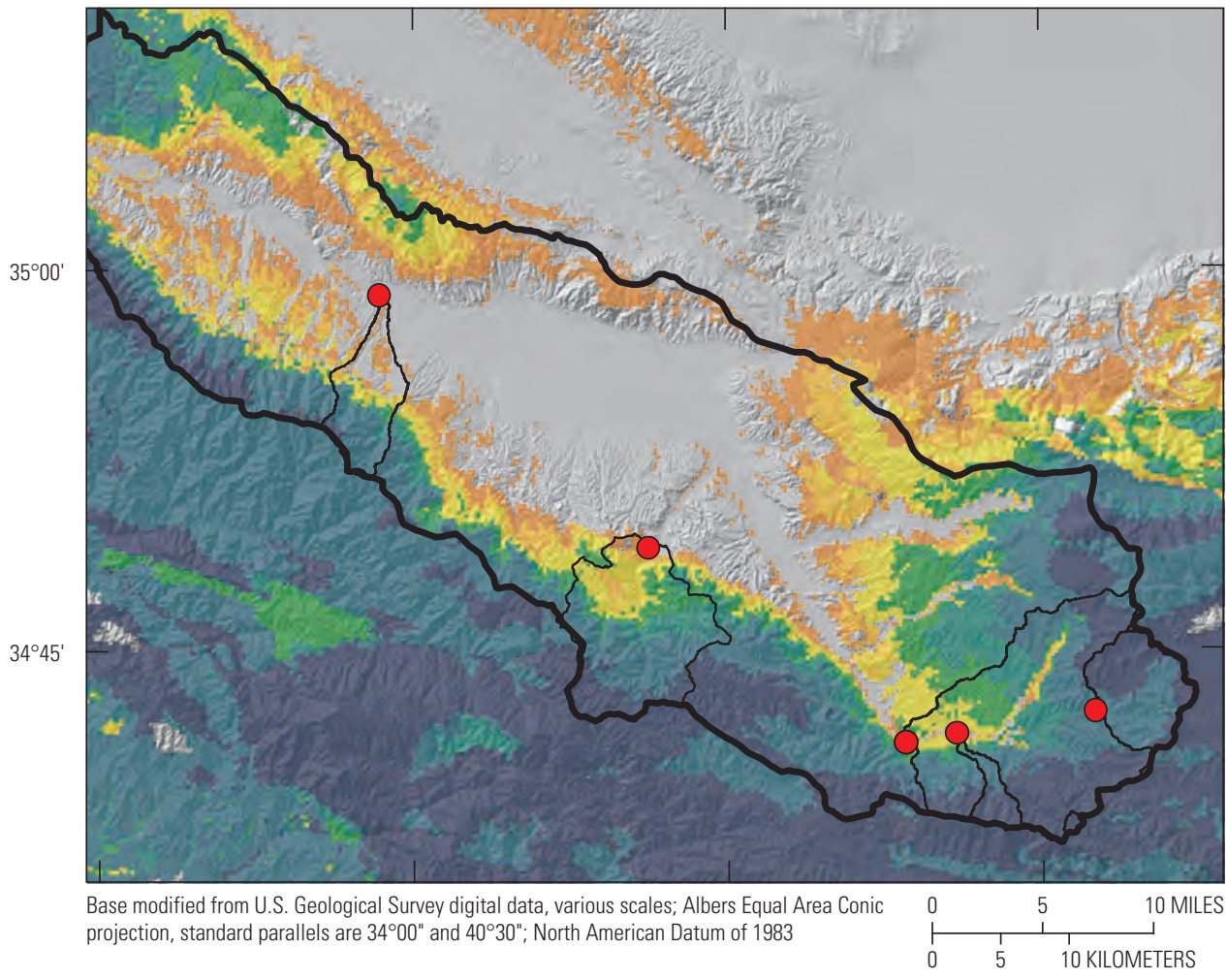

\section{EXPLANATION}

Recharge (1980-2009), in millimeters per year 0 to 10 $>10$ to 20 $>20$ to 30 $>30$ to 50 $>50$ to 70 $>70$ to 100 $>100$ to 200 $>200$ to 300 Cuyama River Basin Calibration basin

Calibration streamgage

Figure 35. Example application of BCMv8 to groundwater-flow model for the Cuyama Valley, California: $A$, geology (from Jennings, 1977), and $B$, recharge. 
A

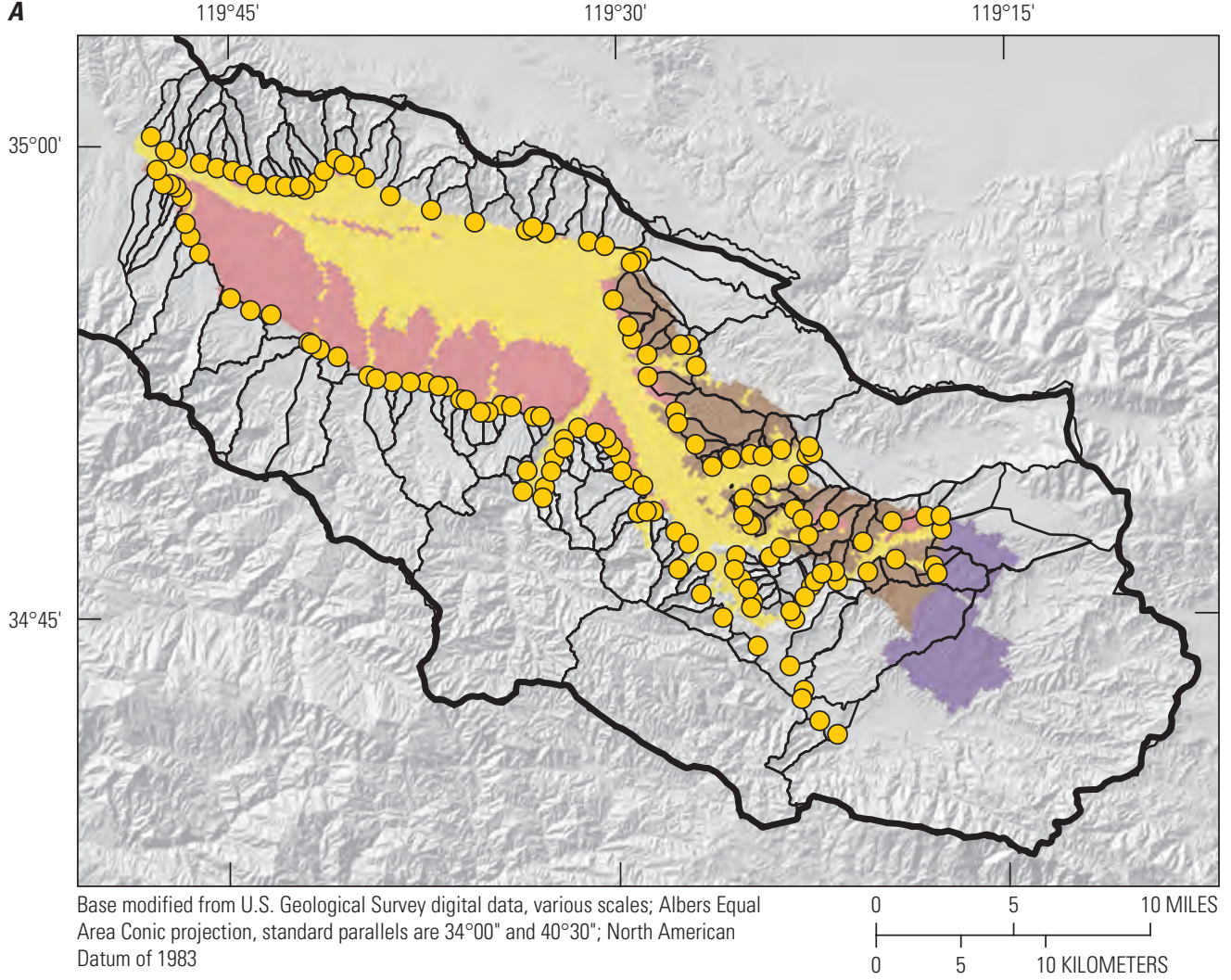

B

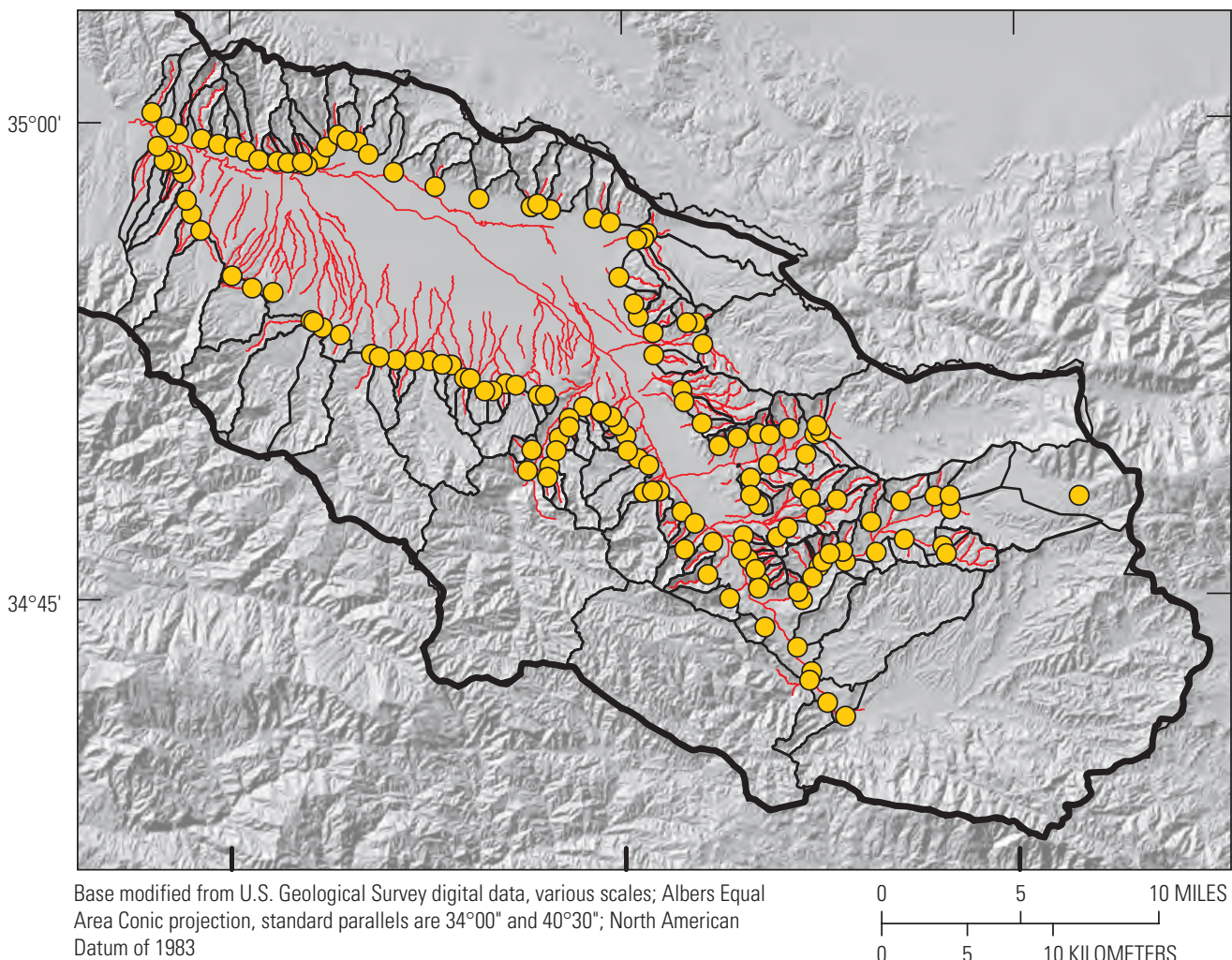

EXPLANATION

Cuyama Modflow model active grid zone
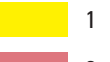

2

3

Cuyama River Basin

New basin

$\bigcirc$ Inflow point
EXPLANATION

Cuyama River Basin

New basin

Cuyama SFR stream

$\bigcirc \quad$ Inflow point

Figure 36. Basins developed for time-series inputs to groundwater flow model for $A$, recharge, and $B$, runoff. (Abbreviation: SFR, streamflow routing package) 


\section{Summary}

The Basin Characterization Model, version 8 (BCMv8), is a monthly, gridded regional water-balance model that incorporates and calculates snow processes, soil-water processes and evapotranspiration, climatic water deficit, and recharge and runoff. This version has been applied to develop a 270 - by 270 -meter $(\mathrm{m})$ resolution, regionally calibrated water balance for California. Version 8 has been revised from previous model versions to incorporate vegetation-specific actual evapotranspiration and a variety of switches to enable users to test and compare scenarios to evaluate potential effects from changes in vegetation, urbanization, managed recharge, or climate to water supply. This user's manual is intended to provide instructions on (1) operation of the existing model for California, (2) the process of clipping all input files to a smaller model domain to perform a local calibration, and (3) the development of new models for other locations or different model-grid resolutions. General guidelines are provided for domain selection and model development.

Example applications are provided to illustrate how the model can be used and parameterized to explore the influences of urbanization on recharge and runoff and how disturbances such as wildfire or forest die-off can influence recharge, runoff, and late-season base flows. Strategic soil organic matter management was shown to improve water supply and reduce landscape stress, and a variety of approaches to analyze climate change are proposed. The capability of the model to evaluate how managed flooding of fields or orchards can increase aquifer recharge is demonstrated, as well as how the $\mathrm{BCMv} 8$ can be used to support groundwater-flow models.

Because the BCMv8 outputs are calculated on a grid-cell basis, results can be summarized across landscapes using summary units of any size of interest, such as watersheds, ecoregions, or political boundaries. The BCMv8 can be used for large model domains (for example, California, the Great Basin, and the Upper and Lower Colorado River Basins have been successfully modeled at 270-m resolution) and for small model domains (University of California reserves at 10-m resolution), as well as for point locations where measured data are available to parameterize the model. If the model is adequately parameterized to estimate basin discharge in hydrologically unimpaired locations, then the model can be used to assess nearby ungaged locations that have similar physical watershed characteristics. The calculation of recharge has been refined with this version because of the addition of vegetation-specific actual evapotranspiration and several switches that can improve estimates of soil water content and dry out, and which can represent gaining and losing streams.

The use of the BCMv8 extends beyond the direct estimates made with the model by providing input and observations for other simulations such as the MODFLOW One-Water integrated hydrologic model. These linkages include applications of historical and future scenarios that need BCMv8 input of precipitation, PET, canopy extent for transpiration throughout the hydrologic model extent, AET and CWD as potential observations, and for runoff and recharge from surrounding watersheds as inflows to surface-water and groundwater-flow networks. 


\section{References Cited}

Ackerly, D.D., Kling, M.M., Clark, M.I., Papper, P., Oldfather, M.F., Flint, A.L., and Flint, L.E., 2020, Topoclimate, refugia, and biotic responses to climate change: Frontiers in Ecology and the Environment, v. 18, no. 5, p. 288-297, https://doi.org/10.1002/fee.2204.

Alkama, R., Decharme, B., Douville, H., and Ribes, A., 2011, Trends in global and basin-scale runoff over the late twentieth century-Methodological issues and sources of uncertainty: Journal of Climate, v. 24, no. 12, p. 3000-3014, https://doi.org/10.1175/2010JCLI3921.1.

Alley, W.M., 1984, On the treatment of evapotranspiration, soil moisture accounting, and aquifer recharge in monthly water balance models: Water Resources Research, v. 20, no. 8, p. 1137-1149, https://doi.org/10.1029/WR020i008p01137.

Anderegg, W.R., Flint, A.L., Huang, C.-Y., Flint, L.E., Berry, J.A., Davis, F., Sperry, J.S., and Field, C.B., 2015, Tree mortality predicted from drought-induced vascular damage: Nature Geoscience, v. 8, no. 5, p. 367-371, https://doi.org/10.1038/ngeo2400.

Anderson, E.A., 2006, Snow accumulation and ablation model-SNOW-17: Silver Spring, Md, U.S. National Weather Service.

Boyce, S.E., Hanson, R.T., Ferguson, I., Schmid, W., Henson, W., Reimann, T., Mehl, S.M., and Earll, M.M., 2020, One-Water Hydrologic Flow Model-A MODFLOW based conjunctive-use simulation software: U.S. Geological Survey Techniques and Methods 6-A60, 435 p., https://doi.org/10.3133/tm6a60.

Bristow, K.L., and Campbell, G.S., 1984, On the relationship between incoming solar radiation and daily maximum and minimum temperature: Agricultural and Forest Meteorology, v. 31, no. 2, p. 159-166, https://doi.org/10.1016/0168-1923(84)90017-0.

California Department of Water Resources Climate Change Technical Advisory Group, 2015, Perspectives and guidance for climate change analysis: Sacramento, Calif., California Department of Water Resources Technical Information Record, $142 \mathrm{p}$.

Chardon, J., Hingray, B., Favre, A.C., Autin, P., Gailhard, J., Zin, I., and Obled, C., 2014, Spatial similarity and transferability of analog dates for precipitation downscaling over France: Journal of Climate, v. 27, no. 13, p. 5056-5074, https://doi.org/10.1175/JCLI-D-13-00464.1.
Chiew, F.H.S., Kirono, D.G.C., Kent, D.M., Frost, A.J., Charles, S.P., Timbal, B., Nguyen, K.C., and Fu, G., 2010, Comparison of runoff modelled using rainfall from different downscaling methods for historical and future climates: Journal of Hydrology (Amsterdam), v. 387, no. 1-2, p. 10-23, https://doi.org/10.1016/j.jhydrol.2010.03.025.

Conlisk, E., Lawson, D., Syphard, A.D., Franklin, J., Flint, L., Flint, A., and Regan, H.M., 2012, The roles of dispersal, fecundity, and predation in the population persistence of an oak (Quercus engelmannii) under global change: PLoS One, v. 7, no. 5, 11 p., https://doi.org/10.1371/journal.pone.0036391.

Curtis, J.A., Flint, L.E., Flint, A.L., Lundquist, J.D., Hudgens, B., Boydston, E.E., and Young, J.K., 2014, Incorporating cold-air pooling into downscaled climate models increases potential refugia for snow-dependent species within the Sierra Nevada Ecoregion, CA: PLoS One, v. 9, no. 9, 13 p., https://doi.org/10.1371/journal.pone.0106984.

Drexler, J.Z., Knifong, D., Tuil, J., Flint, L.E., and Flint, A.L., 2013, Fens as whole-ecosystem gauges of groundwater recharge under climate change: Journal of Hydrology (Amsterdam), v. 481, p. 22-34, https://doi.org/10.1016/j.jhydrol.2012.11.056.

Environmental Systems Research Institute, 2017, ArcGIS, Version 10.5.1: Redlands, Calif., Environmental Systems Research Institute, Inc., p. 1999-2018.

Falcone, J.A., 2011, GAGES-II-Geospatial attributes of gages for evaluating streamflow: U.S. Geological Survey Summary Report, https://doi.org/10.3133/70046617.

Finn, S.P., Kitchell, K., Baer, L.A., Bedford, D., Brooks, M.L., Flint, A.L., Flint, L.E., Matchett, J.R., Mathie, A., Miller, D.M., Pilliod, D., Torregrosa, A., and Woodward, A., 2010, Great Basin Integrated Landscape Monitoring Pilot Summary Report: U.S. Geological Survey Open-File Report 2010-1324, 50 p., https://doi.org/10.3133/ofr20101324.

Flint, A.L., and Childs, S.W., 1987, Calculation of solar radiation in mountainous terrain: Agricultural and Forest Meteorology, v. 40, no. 3, p. 233-249, https://doi.org/10.1016/0168-1923(87)90061-X.

Flint, A.L., and Childs, S.W., 1991, Use of the Priestley-Taylor evaporation equation for soil water limited conditions in a small forest clearcut: Agricultural and Forest Meteorology, v. 56, no. 3-4, p. 247-260, https://doi.org/10.1016/0168-1923(91)90094-7.

Flint, A.L., Flint, L.E., Kwicklis, E.M., Bodvarsson, G.S., and Fabryka-Martin, J.T., 2001, Hydrology of Yucca Mountain: Reviews of Geophysics, v. 39, no. 4, p. 447-470, https://doi.org/10.1029/1999RG000075. 
Flint, A.L., Flint, L.E., Kwicklis, E.M., Fabryka-Martin, J.T., and Bodvarsson, G.S., 2002, Estimating recharge at Yucca Mountain, Nevada, USA - Comparison of methods: Hydrogeology Journal, v. 10, no. 1, p. 180-204, https://doi.org/10.1007/s10040-001-0169-1.

Flint, A.L., Flint, L.E., Hevesi, J.A., and Blainey, J.B., 2004, Fundamental concepts of recharge in the Desert Southwest - A regional modeling perspectiveof Hogan, J.F., Phillips, F.M., and Scanlon, B.R., eds., Groundwater recharge in a desert environment-The southwestern United States: Water Science and Appications, v. 9, p. 159-184, https://doi.org/10.1029/009WSA10.

Flint, A.L., and Ellett, K.M., 2004, The role of the unsaturated zone in artificial recharge at San Gorgonio Pass, California: Vadose Zone Journal, v. 3, no. 3, p. 763-774, https://doi.org/10.2136/vzj2004.0763.

Flint, A.L., Flint, L.E., and Masbruch, M.D., 2011, Input, calibration, uncertainty, and limitations of the Basin Characterization Model, appendix 3 of Heilweil, V.M., and Brooks, L.E., eds, Conceptual model of the Great Basin carbonate and alluvial aquifer system: U.S. Geological Survey Scientific Investigations Report 2010-5193, p. 149164, https://doi.org/10.3133/sir20105193.

Flint, L.E., and Flint, A.L., 2007, Regional analysis of ground-water recharge, chap. B of Stonestrom, D.A., Constantz, J., Ferré, T.P.A., and Leake, S.A., eds., Ground-water recharge in the arid and semiarid southwestern United States: U.S. Geological Professional Paper 1703-B, p. 29-60, https://doi.org/10.3133/pp1703B.

Flint, L.E., and Flint, A.L., 2012, Downscaling future climate scenarios to fine scales for hydrologic and ecological modeling and analysis: Ecological Processes, v. 1, no. 2, 15 p., https://doi.org/10.1186/2192-1709-1-2.

Flint, L.E., Flint, A.L., Thorne, J.H., and Boynton, R., 2013, Fine-scale hydrologic modeling for regional landscape applications - The California Basin Characterization Model development and performance: Ecological Processes, v. 2, no. 25, 21 p., https://doi.org/10.1186/2192-1709-2-25.

Flint, L.E., and Flint, A.L., 2014, California Basin Characterization Model-A dataset of historical and future hydrologic response to climate change: U.S. Geological Survey data release, https://doi.org/10.5066/F76T0JPB.

Flint, L.E., Flint, A.L., Curtis, J.A., Delaney, C., and Mendoza, J., 2015, Provisional simulated unimpaired mean daily streamflow in the Russian River and Upper Eel River Basins, California, under historical and projected future climates: U.S. Geological Survey data release, https://ca.water.usgs.gov/projects/reg_hydro/russian-riverstreamflow.html.
Flint, L., Flint, A., Stern, M., Mayer, A., Silver, W., Casey, F., Franco, F., Byrd, K., Sleeter, B., Alvarez, P., Creque, J., Estrada, T., and Cameron, D., 2018, Increasing soil organic carbon to mitigate greenhouse gases and increase climate resiliency for California: California's Fourth Climate Change Assessment, California Natural Resources Agency, Publication number: CNRA-CCC4A-2018-XXX, https://pdfs.semanticscholar.org/301f/ 968fd9bf25dd78d8415c1ebaf6fd4f303deb.pdf.

Gee, G.W., and Hillel, D., 1988, Groundwater recharge in arid regions - Review and critique of estimation methods: Hydrological Processes, v. 2, no. 3, p. 255-266, https://doi.org/10.1002/hyp.3360020306.

Hay, L.E., Markstrom, S.L., and Ward-Garrison, C., 2011, Watershed-scale response to climate change through the twenty-first century for selected basins across the United States: Earth Interactions, v. 15, no. 17, p. 1-37, https://doi.org/10.1175/2010EI370.1.

Hanson, R.T., Boyce, S.E., Schmid, W., Hughes, J.D., Mehl, S.M., Leake, S.A., Maddock, T., III, and Niswonger, R.G., 2014a, MODFLOW-One-Water Hydrologic Flow Model (OWHM): U.S. Geological Survey Techniques and Methods 6-A51, 122 p., https://doi.org/10.3133/tm6A51.

Hanson, R.T., Flint, L.E., Faunt, C.C., Gibbs, D.R., and Schmid, W., 2014b, Hydrologic models and analysis of water availability in Cuyama Valley, California: U.S. Geological Survey Scientific Investigations Report 2014-5150, 150 p., https://doi.org/10.3133/sir20145150.

Hanson, R.T., Flint, L.E., Flint, A.L., Dettinger, M.D., Faunt, C.C., Cayan, D., and Schmid, W., 2012, A method for physically based model analysis of conjunctive use in response to potential climate changes: Water Resources Research, v. 48, no. 6, 23 p., https://doi.org/10.1029/2011WR010774.

Hevesi, J.A., Flint, A.L., and Flint, L.E., 2003, Simulation of net infiltration and potential recharge using a distributed-parameter watershed model of the Death Valley region, Nevada and California: U.S. Geological Survey Water-Resources Investigations Report 2003-4090, 171 p., https://doi.org/10.2172/815988.

Hopp, L., and McDonnell, J.J., 2009, Connectivity at the hillslope scale-Identifying interactions between storm size, bedrock permeability, slope angle and soil depth: Journal of Hydrology (Amsterdam), v. 376, no. 3-4, p. 378-391, https://doi.org/10.1016/j.jhydrol.2009.07.047.

Hutchinson, D.G., and Moore, R.D., 2000, Throughflow variability on a forested hillslope underlain by compacted glacial till: Hydrological Processes, v. 14, no. 10, p. 1751-1766, https://doi.org/10.1002/10991085(200007)14:10<1751::AID-HYP68>3.0.CO;2-U. 
Izbicki, J.A., Flint, A.L., and Stamos, C.L., 2008, Artificial recharge through a thick, heterogeneous unsaturated zone: Ground Water, v. 46, no. 3, p. 475-488, https://doi.org/10.1111/j.1745-6584.2007.00406.x.

Jennings, C.W., 1977, Geologic map of California: California Division of Mines and Geology geologic data, Map number 2, scale 1:750,000.

Jones, J.P., Sudicky, E.A., Brookfield, A.E., and Park, Y.J., 2006, An assessment of the tracer-based approach to quantifying groundwater contributions to stream flow: Water Resources Research, v. 42, no. 2, 15 p., https://doi.org/10.1029/2005WR004130.

Leavesley, G.H., Lichty, R.W., Troutman, B.M., and Saindon, L.G., 1983, Precipitation-runoff modeling system-User's manual: U.S. Geological Survey Water Resources Investigations Report 83-4238, 207 p., https://doi.org/10.3133/wri834238.

Liang, X., Lettenmaier, D.P., Wood, E.F., and Burges, S.J., 1994, A simple hydrologically based model of land surface water and energy fluxes for general circulation models: Journal of Geophysical Research-Atmospheres, v. 99, no. D7, p. 14415-14428, https://doi.org/10.1029/94JD00483.

Livneh, B., Rosenberg, E.A., Lin, C., Nijssen, B., Mishra, V., Andreadis, K.M., Maurer, E.P., and Lettenmaier, D.P., 2013, A long-term hydrologically based dataset of land surface fluxes and states for the conterminous United StatesUpdate and extensions: Journal of Climate, v. 26, no. 23, p. 9384-9392, https://doi.org/10.1175/JCLI-D-12-00508.1.

Maher, S.P., Morelli, T.L., Hershey, M., Flint, A.L., Flint, L.E., Moritz, C., and Beissinger, S.R., 2017, Erosion of refugia in the Sierra Nevada meadows network with climate change: Ecosphere, v. 8, no. 4, 17 p., https://doi.org/10.1002/ecs2.1673.

Mann, M.L., Batllori, E., Moritz, M.A., Waller, E.K., Berck, P., Flint, A.L., Flint, L.E., and Dolfi, E., 2016, Incorporating anthropogenic influences into fire probability models - Effects of human activity and climate change on fire activity in California: PLoS One, v. 11, no. 4, 21 p., https://doi.org/10.1371/journal.pone.0153589.

Maurer, E.P., Hidalgo, H.G., Das, T., Dettinger, M.D., and Cayan, D.R., 2010, The utility of daily large-scale climate data in the assessment of climate change impacts on daily stream flow in California: Hydrology and Earth System Sciences, v, 14, p. 1125-1138, https://doi.org/10.5194/hess-14-1125-2010.
McCullough, I.M., Davis, F.W., Dingman, J.R., Flint, L.E., Flint, A.L., Serra-Diaz, J.M., Syphard, A.D., Moritz, M.A., Hannah, L., and Franklin, J., 2015, High and dryHigh elevations disproportionately exposed to regional climate change in Mediterranean-climate landscapes: Landscape Ecology, v. 31, no. 5, p. 1063-1075, https://doi.org/10.1007/s10980-015-0318-x.

McIntyre, P.J., Thorne, J.H., Dolanc, C.R., Flint, A.L., Flint, L.E., Kelly, M., and Ackerly, D.D., 2015, Twentieth-century shifts in forest structure in CaliforniaDenser forests, smaller trees, and increased dominance of oaks: Proceedings of the National Academy of Sciences of the United States of America, v. 112, no. 5, p. 1458-1463, https://doi.org/10.1073/pnas.1410186112.

Millar, C.I., Westfall, R.D., Delany, D.L., Flint, A.L., and Flint, L.E., 2015, Recruitment patterns and growth of high-elevation pines in response to climatic variability (1883-2013), western Great Basin, USA: Canadian Journal of Forest Research, v. 45, no. 10, p. 1299-1312, https://doi.org/10.1139/cjfr-2015-0025.

Morelli, T.L., Maher, S.P., Lim, M.C., Kastely, C., Eastman, L.M., Flint, L.E., Flint, A.L., Beissinger, S.R., and Moritz, C., 2017, Climate change refugia and habitat connectivity promote species persistence: Climate Change Responses, v. 4, no. 8, 12 p., https://doi.org/10.1186/s40665-017-0036-5.

Muñoz-Rojas, M., Erickson, T.E., Dixon, K.W., and Merritt, D.J., 2016, Soil quality indicators to assess functionality of restored soils in degraded semiarid ecosystems: Restoration Ecology, v. 24, no. S2, p. S43-S52, https://doi.org/10.1111/rec.12368.

Pierce, D.W., Cayan, D.R., and Thrasher, B.L., 2014, Statistical downscaling using localized constructed analogs (LOCA): Journal of Hydrometeorology, v. 15, no. 6, p. 2558-2585, https://doi.org/10.1175/JHM-D-14-0082.1.

Priestley, C.H.B., and Taylor, R.J., 1972, On the assessment of surface heat flux and evaporation using large-scale parameters: Monthly Weather Review, v. 100, no. 2, p. 81-92, https://doi.org/10.1175/15200493(1972)100\%3C0081:OTAOSH\%3E2.3.CO;2.

Ragab, R., Finch, J., and Harding, R., 1997, Estimation of groundwater recharge to chalk and sandstone aquifers using simple soil models: Journal of Hydrology (Amsterdam), v. 190, no. 1-2, p. 19-41, https://doi.org/10.1016/S0022-1694(96)03067-3.

Reba, M.L., Marks, D., Winstral, A., Link, T.E., and Kumar, M., 2011, Sensitivity of the snowcover energetics in a mountain basin to variations in climate: Hydrological Processes, v. 25, no. 21, p. 3312-3321, https://doi.org/10.1002/hyp.8155. 
Reitz, M., Sanford, W.E., Senay, G.B., and Cazenas, J., 2017, Annual Estimates of Recharge, Quick-Flow Runoff, and Evapotranspiration for the Contiguous US Using Empirical Regression Equations: Journal of the American Water Resources Association, v. 53, no. 4, p. 961-983, https://doi.org/10.1111/1752-1688.12546.

Risley, J., Moradkhani, H., Hay, L., and Markstrom, S., 2011, Statistical comparisons of watershed-scale response to climate change in selected basins across the United States: Earth Interactions, v. 15, no. 14, p. 1-26, https://doi.org/10.1175/2010EI364.1.

Sanford, W.E., Plummer, L.N., McAda, D.P., Bexfield, L.M., and Anderholm, S.K., 2001, Estimation of hydrologic parameters for the groundwater model of the Middle Rio Grande Basin using carbon-14 and water-level data, U.S. Geological Survey Middle Rio Grande Basin Study: Proceedings of the Fourth Annual Workshop, Albuquerque, NM, 15-16 February 2000, U.S. Geological Survey Open-File Report 2000-488.

Saxton, K.E., and Rawls, W.J., 2006, Soil water characteristic estimates by texture and organic matter for hydrologic solutions: Soil Science Society of America Journal, v. 70, no. 5, p. 1569-1578, https://doi.org/10.2136/sssaj2005.0117.

Sengupta, M., Habte, A., Gotseff, P., Weekley, A., Lopez, A., Molling, C., and Heidinger, A., 2014, Physics-Based GOES Satellite Product for Use in NREL's National Solar Radiation Database: Preprint, NREL Report No. CP-5D00-62237, 9 p.
Szilágyi, J., Kovacs, A., and Jozsa, J., 2011, A calibration-free evapotranspiration mapping (CREMAP) technique: INTECH, Rijeka, Croatia, www.intechopen.com/books/ show/title/evapotranspiration.

Thorne, J.H., Boynton, R.M., Flint, L.E., and Flint, A.L., 2015, The magnitude and spatial patterns of historical and future hydrologic change in California's watersheds: Ecosphere, v. 6, no. 2, p. 1-30, https://doi.org/10.1890/ES14-00300.1.

Tromp-van Meerveld, H.J., Peters, N.E., and McDonnell, J.J., 2007, Effect of bedrock permeability on subsurface stormflow and the water balance of a trenched hillslope at the Panola Mountain Research Watershed, Georgia, USA-Hydrological Processes: International Journal (Toronto, Ont.), v. 21, no. 6, p. 750-769, https://doi.org/10.1002/hyp.6265.

van Mantgem, P.J., Nesmith, J.C.B., Keifer, M.B., Knapp, E.E., Flint, A.L., and Flint, L.E., 2013, Climatic stress increases forest fire severity across the western United States: Ecology Letters, v. 16, no. 9, p. 1151-1156, https://doi.org/10.1111/ele.12151.

Willmott, C.J., and Kenyi, M., 2001, Terrestrial water budget data archive: monthly time series (1950-1999): University of Wisconsin, www.nelson.wisc.edu/sage/data-and-models/ atlas/maps.php?datasetid $=46 \&$ includerelatedlinks $=$ $1 \&$ dataset $=46$.

Wood, A.W., Maurer, E.P., Kumar, A., and Lettenmaier, D.P., 2002, Long-range experimental hydrologic forecasting for the eastern United States: Journal of Geophysical Research, D, Atmospheres, v. 107, no. D20, p. ACL 6-1-ACL 6-15, https://doi.org/10.1029/2001JD000659. 


\section{Appendix 1. Control File for BCMv8}

BCM Monthly v8.ctl: California domain model using the Teale projection

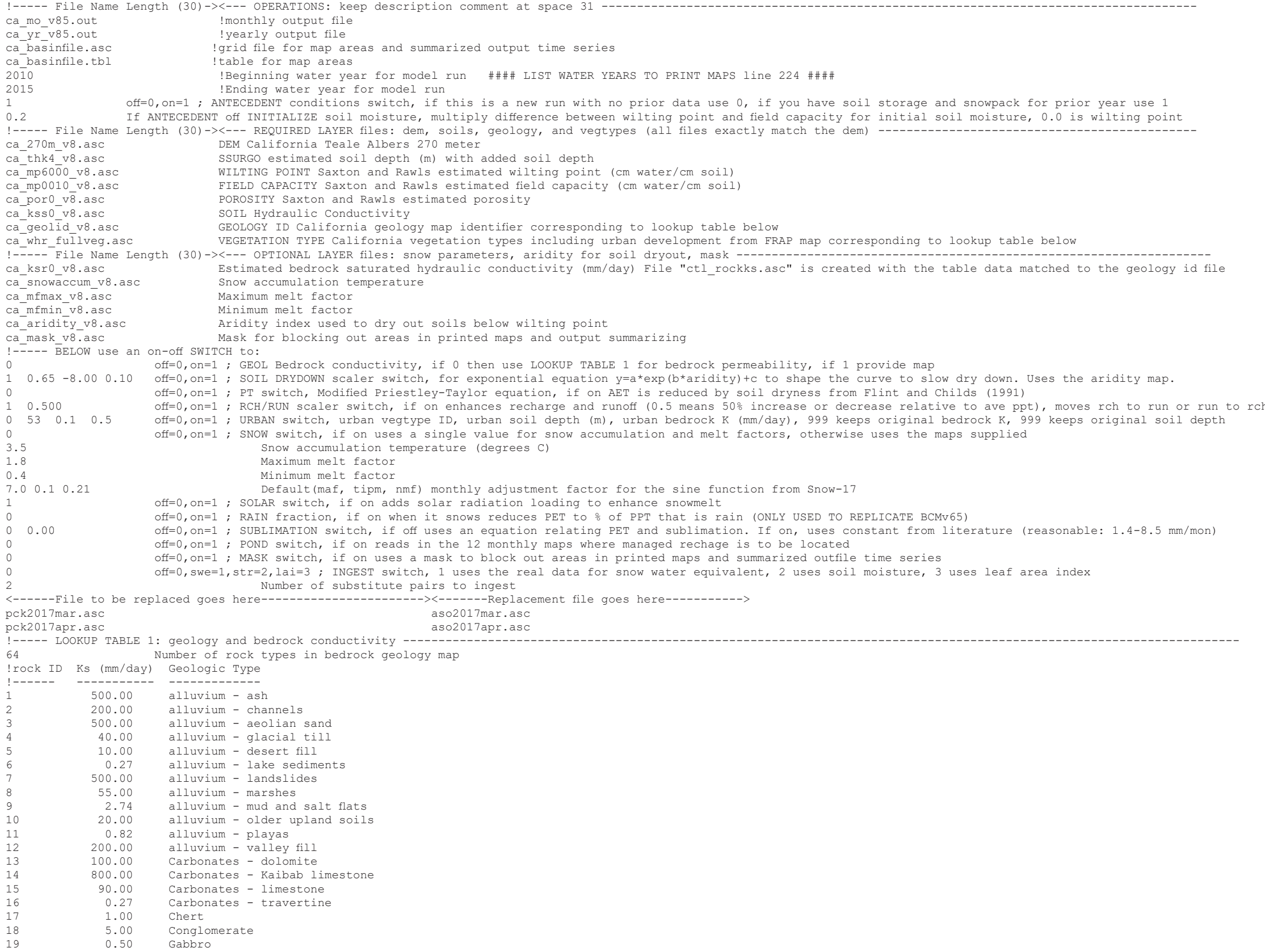

$\begin{aligned} 500.00 & \text { alluvium - ash } \\ 200.00 & \text { alluvium - channels } \\ 500.00 & \text { alluvium - aeolian sand } \\ 40.00 & \text { alluvium - glacial till } \\ 10.00 & \text { alluvium - desert fill } \\ 0.27 & \text { alluvium - lake sediments } \\ 500.00 & \text { alluvium - landsides } \\ 55.00 & \text { alluvium - marshes } \\ 2.74 & \text { alluvium - mud and salt flats } \\ 20.00 & \text { alluvium - older upland soils } \\ 0.82 & \text { alluvium - playas } \\ 200.00 & \text { alluvium - valley fill } \\ 100.00 & \text { Carbonates - dolomite } \\ 800.00 & \text { Carbonates - Kaibab limestone } \\ 90.00 & \text { Carbonates - limestone } \\ 0.27 & \text { Carbonates - travertine } \\ 1.00 & \text { Chert } \\ 5.00 & \text { Conglomerate } \\ 0.50 & \text { Gabbro }\end{aligned}$




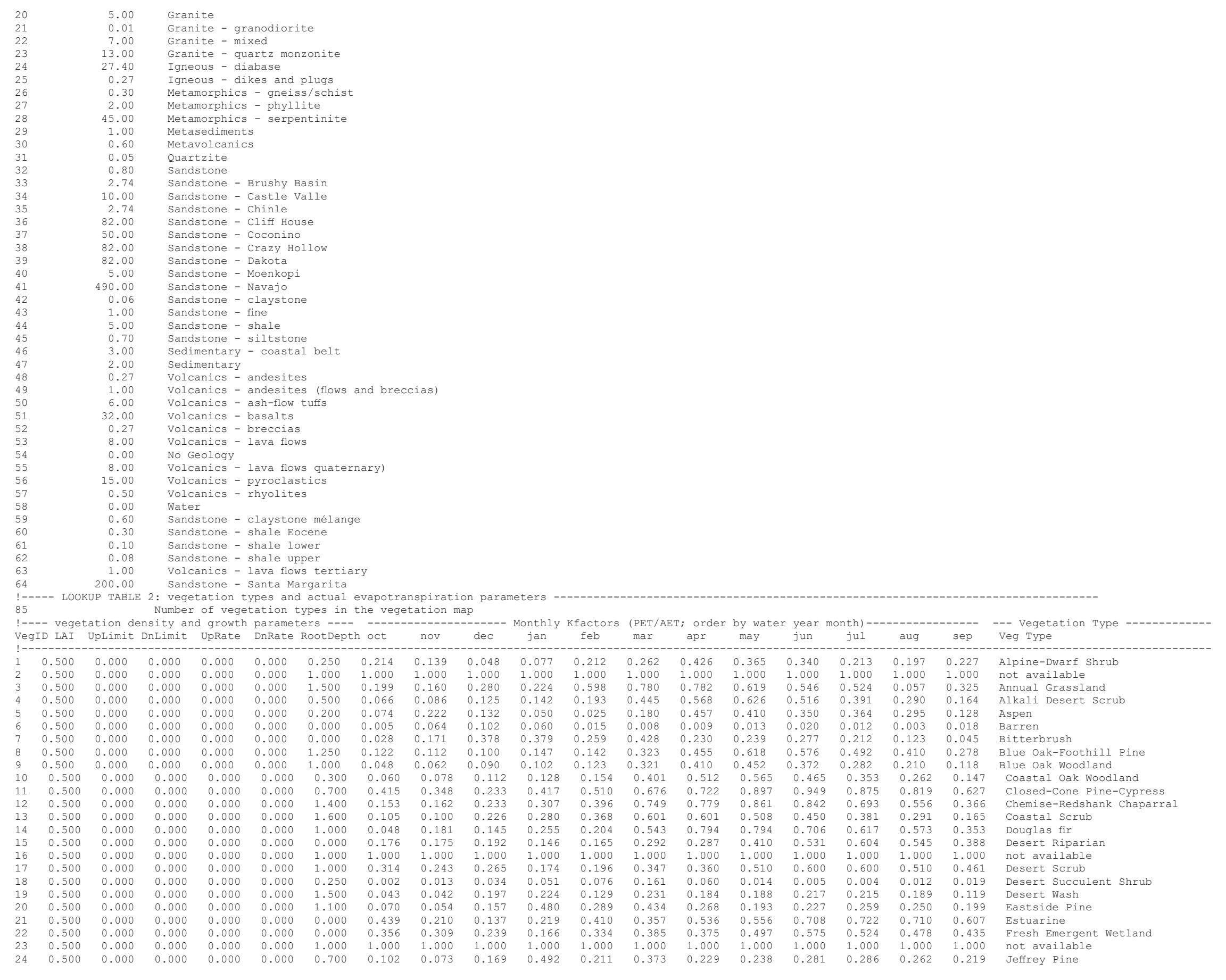




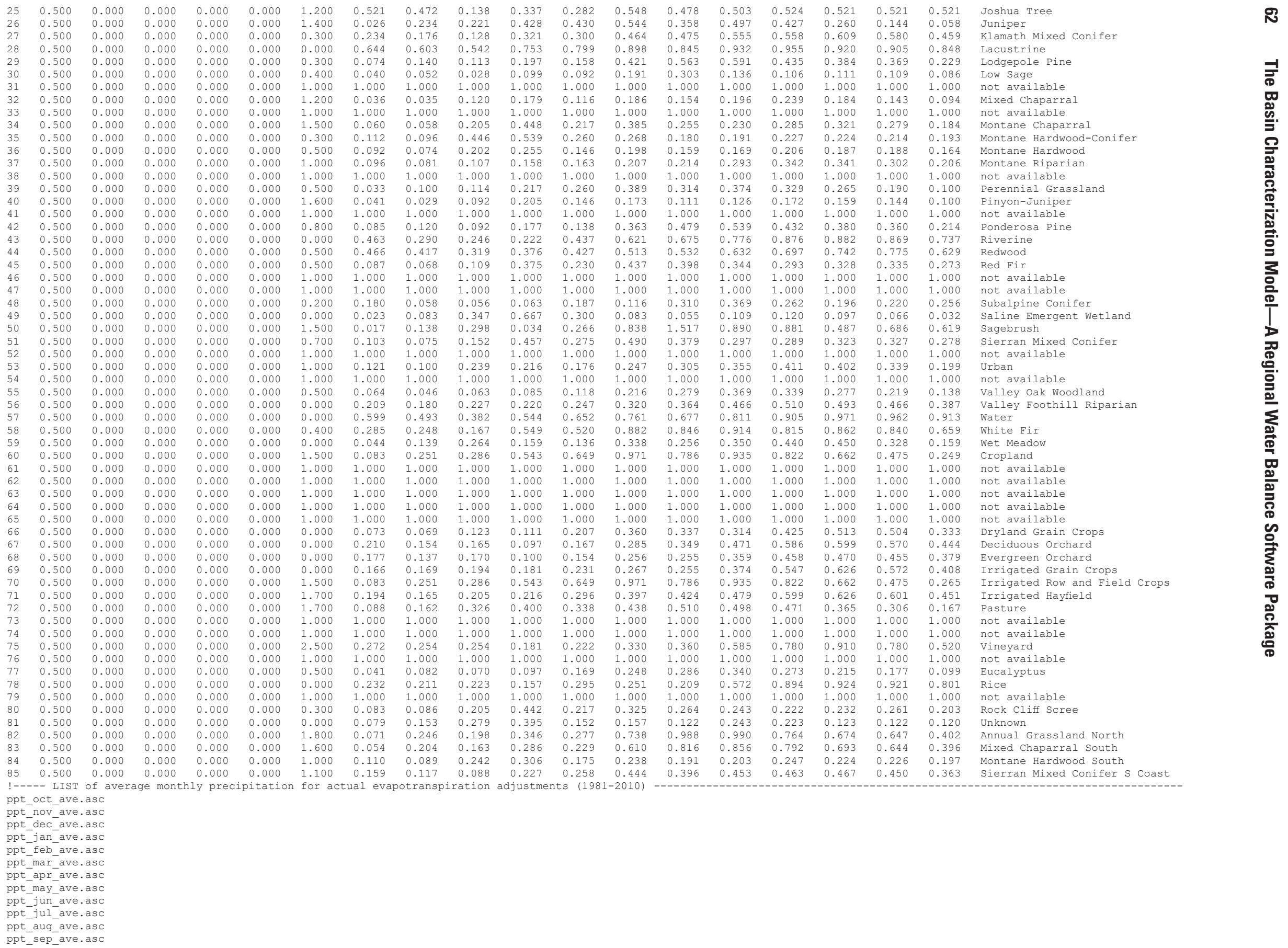


ppt_ann ave.asc

the monthly solar radiation files for melting snow

rad_oct_ave.asc

$\mathrm{rad}^{-}$dec ave.asc

rad jan ave.asc

rad_feb_ave.asc

rad_mar_ave.asc

rad_apr_ave.asc

rad may_ave.asc

rad_jul_ave.asc

rad aug ave.asc

!----- IIST of optional average monthly flooding maps for simulating managed aquifer recharge

oct_flood.asc

dec flood.asc

dec_flood.asc
jan_flood.asc

feb_flood.asc

mar_llood.asc

apr_flood.asc

jun flood. asc

jul flood.asc

aug flood.asc

WATER YEARS TO PRINT OUT MAPS ---- number of water years to print out
!

2010

2011

2013

915

otes below

water years printed:

exc excess water

et actual evapotranspiration

ch recharge

run runoff 


\section{Appendix 2. Procedure for Developing a BCMv8 at Finer Scales or for New Model Domains}

This procedure describes the steps to develop a $\mathrm{BCMv} 8$ from scratch for areas outside of California or for different grid-cell resolutions. It is recommended that the earlier descriptions in the user's manual be studied prior to following the procedure; then the procedural steps can be followed to set up and calibrate a new model. The following workflow is intended to guide the user through the entire process, indicates the pre-processing steps and FORTRAN codes or software used for each step, how the model is run and calibrated, and post-processing steps to iterate the steps to improve model calibration (fig. 2.1).

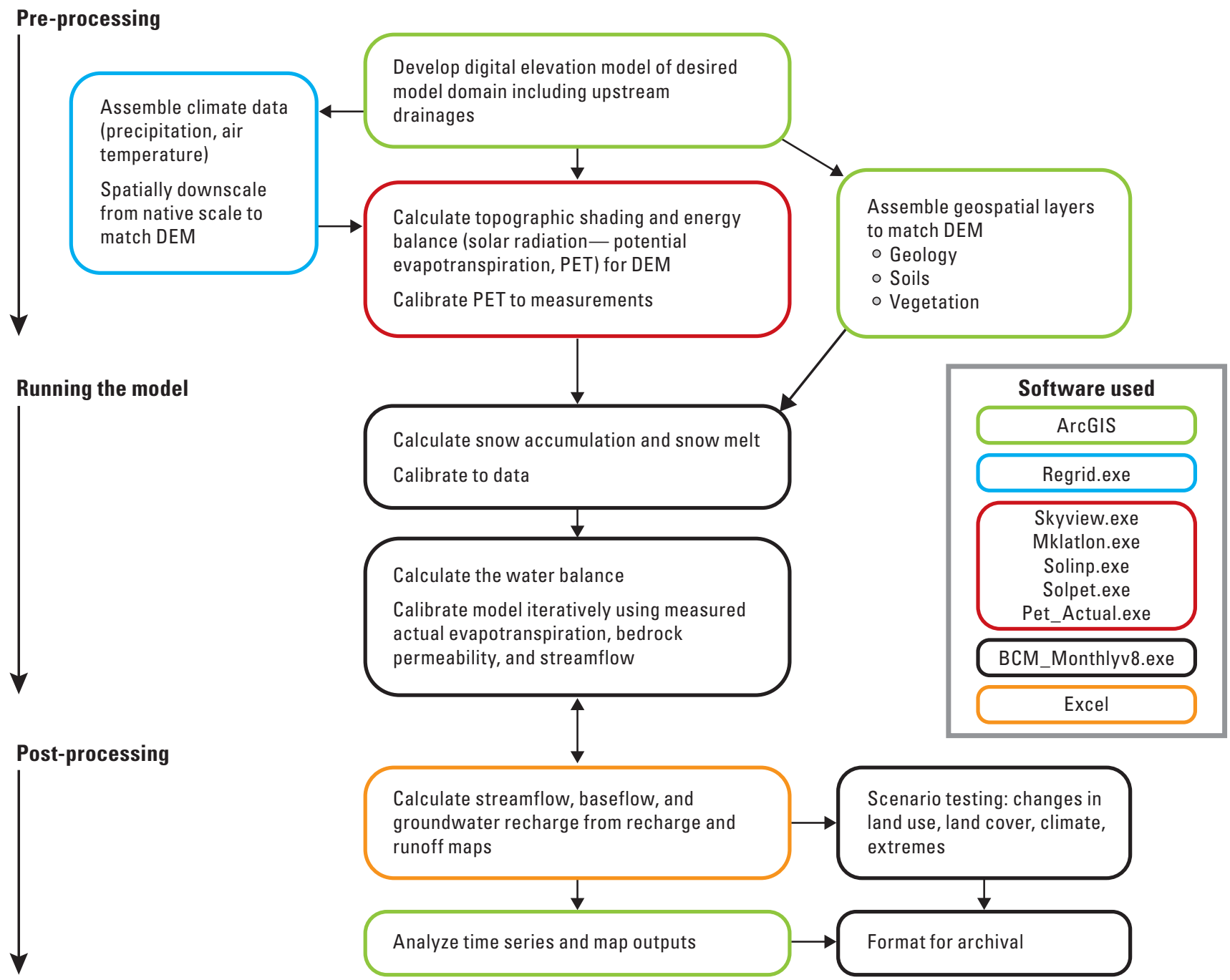

Figure 2.1. Diagram of workflow for developing and running a new Basin Characterization Model, version 8. 


\section{Setting Up a New Monthly BCMv8 Project}

Required layer file inputs to $\mathrm{BCMv} 8$ to be obtained or developed by this procedure (all layers must be ASCII grid files) unless marked with an asterisk (*), meaning "optional," (depending on data or switches used):

1. Digital elevation model (DEM)

2. Basin file

3. Soil properties (soil depth, soil-water content at wilting point and field capacity, porosity, percentage sand*, percentage silt*, percentage clay*, soil organic matter content*)

4. Geology (or bedrock conductivity*)

5. Soil saturated hydraulic conductivity*

6. Vegetation map (fullveg, partveg*)

7. Snow parameters* (snow accumulation, maximum melt factor, minimum melt factor)

8. Aridity index*

9. Mask*

10. 30-year monthly means of precipitation and solar radiation

11. 30-year annual average precipitation

12. Monthly maps of flooding*

Climate files to be developed for desired period of record:

13. Monthly minimum and maximum air temperature

14. Monthly precipitation

15. Monthly potential evapotranspiration

FORTRAN codes used to develop a new BCMv8

1. ClipGrid (ClipGridv1.exe) - clips any ASCII grid to a smaller ASCII grid file.

2. Regrid (Regridv3.exe) - used to spatially downscale a coarse grid to a finer resolution grid.

3. Skyview (Skyviewv1.exe) - used to analyze topographic shading and develops 12 monthly maps of percentage of sky viewed for 24 radial degrees for each grid cell.

4. Mklatlon (Mklatlonv1.exe) - identifies the location of every grid cell for the calculation of solar radiation and develops maps of latitude and longitude.

5. Solinp (Solinpv1.exe) - develops the SolPET input file using outputs from Skyview and Mklatlon.
6. SolPET (SolPET6.exe) - calculates clear-sky hourly solar radiation and potential evapotranspiration.

7. PET_Actual (PET_Actualv1.exe) - uses minimum and maximum temperature and the Priestley-Taylor equation to calculate monthly potential evapotranspiration corrected for cloudiness.

8. SoilProps (SoilPropsv1.exe) - uses percentages of sand, silt, and clay, and soil organic matter to calculate soil porosity, wilting point, and field capacity.

9. BCMv8 (BCM_Monthlyv8.exe) - Basin Characterization Model, version 8.

\section{Developing Input Files}

\section{To Develop Digital Elevation Model (DEM) and Basin File}

1. Develop a basin file, ensuring that all upstream areas from streamgages used for calibration are included (fig. 2.2A). A basin file determines the subbasins for which the BCMv8 summarizes monthly data in the outfile. It is often useful to prepare a basin file before developing the final DEM.

2. Aggregate all subbasins to areas upstream from calibration streamgages (fig. 2.2B). If needed for calibration, include sensor locations for snow-water equivalent or snowpack.

3. Develop a digital elevation model (DEM) for the study area that encompasses the basin file with desired grid-cell resolution and choose an appropriate map projection for the project and study area (fig. 2.2C).

4. Convert basin shapefile to raster equivalent on the basis of unique identifiers (integers) for each basin or sensor (fig. 2.2D). Every input file and climate file are to be in ASCII grid format and must match the map projection, extent, and grid size of this file exactly, with the same header, rows, columns, and corner locations (fig. 2.2E).

5. Prepare a table file for use by the model to summarize data into basins or sensors as time series (fig. 2.2F).

6. If there are any locations in your DEM that are not covered by a basin ID, the map output grids do not calculate anything for those cells and they are coded as "no data" (corresponding to noData value in ASCII file header). To ensure there are no holes in your output maps, create an additional subbasin that covers the areas that do not have a defined subbasin. Additionally, if any input layer file has "no data" locations, these locations will have noData values in the output. 
$\boldsymbol{A}$

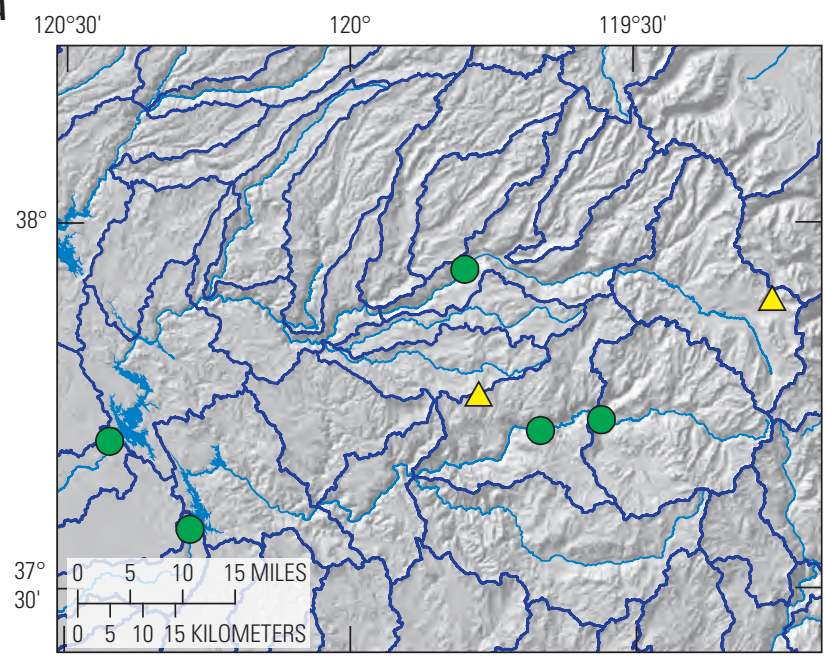

Base modified from U.S. Geological Survey digital data, various scales; Albers Equal Area Conic projection, standard parallels are $34^{\circ} 00^{\prime \prime}$ and $40^{\circ} 30^{\prime \prime}$; North American Datum of 1983

\section{EXPLANATION}

- Watershed-boundary dataset $\triangle$ Snow sensor $\bigcirc$ Streamgage

C

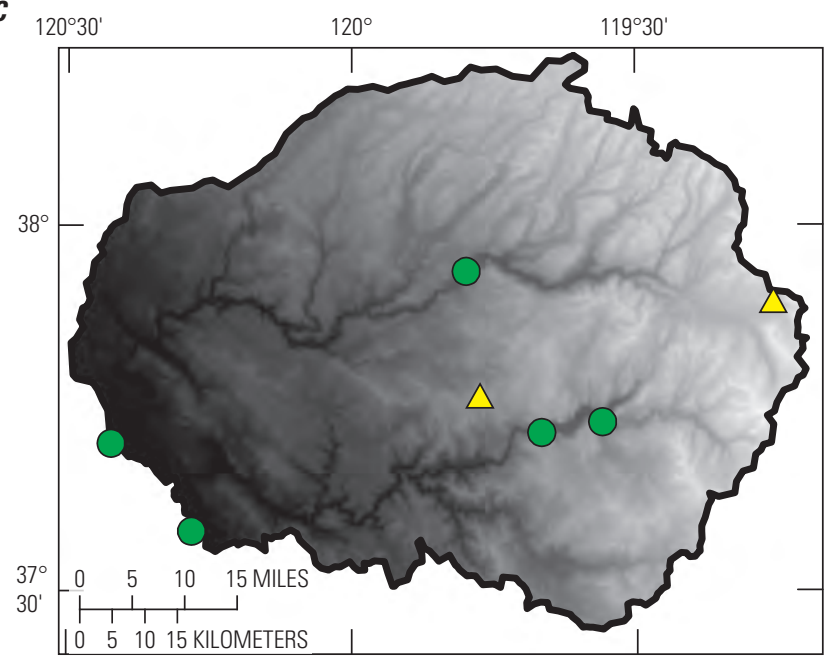

Base modified from U.S. Geological Survey digital data, various scales; Albers Equal Area Conic projection, standard parallels are $34^{\circ} 00^{\prime \prime}$ and $40^{\circ} 30^{\prime \prime}$; North American Datum of 1983

\section{EXPLANATION}

Digital elevation model (DEM)

$\triangle$ Snow sensor

MT_domain

Streamgage
B

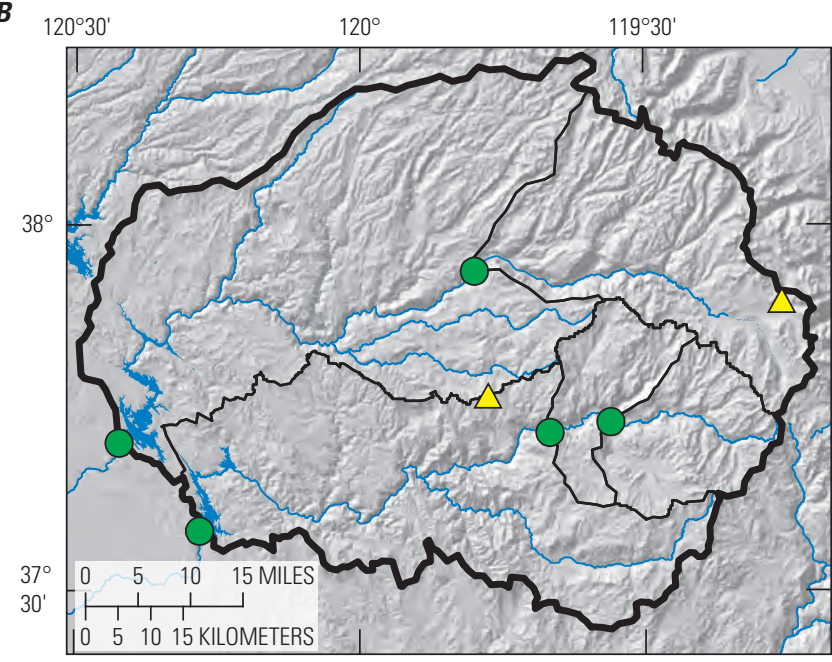

Base modified from U.S. Geological Survey digital data, various scales; Albers Equal Area Conic projection, standard parallels are $34^{\circ} 00^{\prime \prime}$ and $40^{\circ} 30^{\prime \prime}$; North American Datum of 1983

\section{EXPLANATION}

MT_basins MT_domain

$\triangle$ Snow sensor Streamgage

D

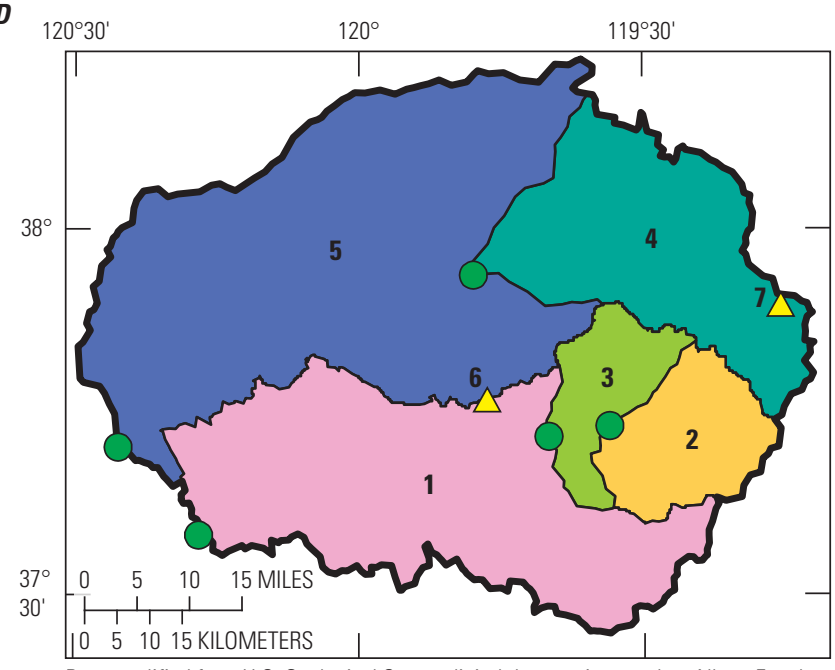

Base modified from U.S. Geological Survey digital data, various scales; Albers Equal Area Conic projection, standard parallels are $34^{\circ} 00^{\prime \prime}$ and $40^{\circ} 30^{\prime \prime}$; North American Datum of 1983

\section{EXPLANATION}

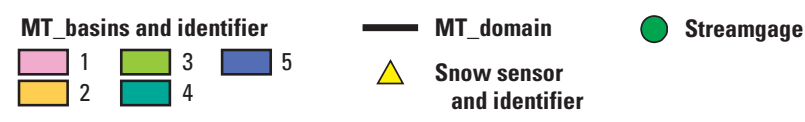

$\boldsymbol{F}$

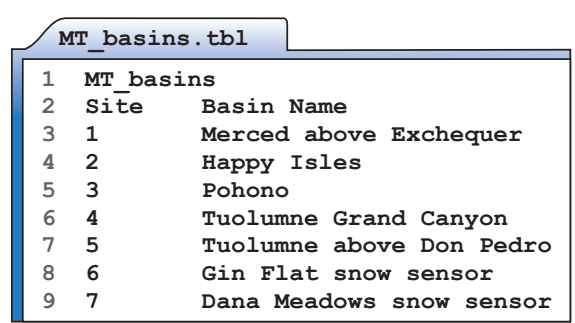

Figure 2.2. Development of a basin file: $A$, step 1-begin with HUC-10 shapefile of watersheds; $B$, step 2-aggregate watersheds in areas upstream from streamgages; $C$, step 3-clip the DEM to outer boundary; $D$, step 4-convert shapefile to raster file, then to ASCII file; $E$, ensure the file header exactly matches the DEM header; and $F$, step 5 -create a table file that describes the new basins. 


\section{Developing Soil Properties}

Download local or regional grids of soil depth (meters), water content at wilting point (centimeter water/centimeter soil), water content at field capacity ( $\mathrm{cm}$ water/ $\mathrm{cm}$ soil), porosity (millimeter/day), and saturated hydraulic conductivity (mm/day). Data for the United States and select nearby countries are available at https://datagateway.nrcs.usda.gov/. Soil grids must be projected to register with and clipped to the project DEM and exported as ASCII files.

Alternately, to calculate soil hydraulic properties for water contents at field capacity and wilting point that differ from those available from Natural Resources Conservation Service (NRCS), download soil-texture data (percent sand, silt, and clay) and percent soil organic-matter grids, along with porosity and bulk density. The FORTRAN code "SoilPropsv1" is used to calculate water content at field capacity at 0.01 and $0.033 \mathrm{MPa}$ and water content at wilting point at 1.5, 3.0, and $6.0 \mathrm{MPa}$.

\section{To Calculate Soil Hydraulic Properties Using SoilPropsv1}

1. Download percent sand (psand), percent silt (psilt), percent clay (pclay), percent soil organic matter (som), bulk density (bd), and porosity (por) from https://datagateway.nrcs.usda.gov.

2. Clip and project the soil grids to the project DEM, and export as ASCII files.

3. Develop SoilPropsv1 control file (SoilPropsv1.ctl; fig. 2.3)
4. Run SoilPropsv1 to calculate water content at wilting point (mp1500, mp3000, or mp6000) and water content at field capacity (mp0010 or mp0033).

5. Choose hydraulic properties as necessary for optimum calibration.

\section{Developing Geology Map and Bedrock Conductivity}

Obtain or develop local or regional geology map grid clipped to the study area, after first being reprojected to the map projection and extent of the project DEM. Shallow bedrock saturated hydraulic conductivity $(\mathrm{K}, \mathrm{mm} /$ day) values correspond to LOOKUP table 1 in the BCM_monthlyv8 control file and the bedrock $\mathrm{K}$ values can be adjusted during calibration.

\section{Developing Climate Grids}

Any gridded climate data can be used (for example, PRISM: www.prism.oregonstate.edu/, Daymet: https://daymet.ornl.gov/, Livneh: https://www.esrl.noaa.gov/ psd/data/gridded/data.livneh.html, WorldClim: www.worldclim.org/, VIC: https://rdrr.io/cran/VICmodel/). Climate data can be used directly if the grid-cell resolution is adequate for the project goals, or climate grids can be downscaled to a smaller DEM grid-cell resolution, depending on project DEM resolution. To downscale PRISM grids, as an example, follow the steps that follow. See figure 2.4 for a workflow indicating the sequence of processes to develop new climate files and potential evapotranspiration using PRISM data and an existing BCMv8 model.

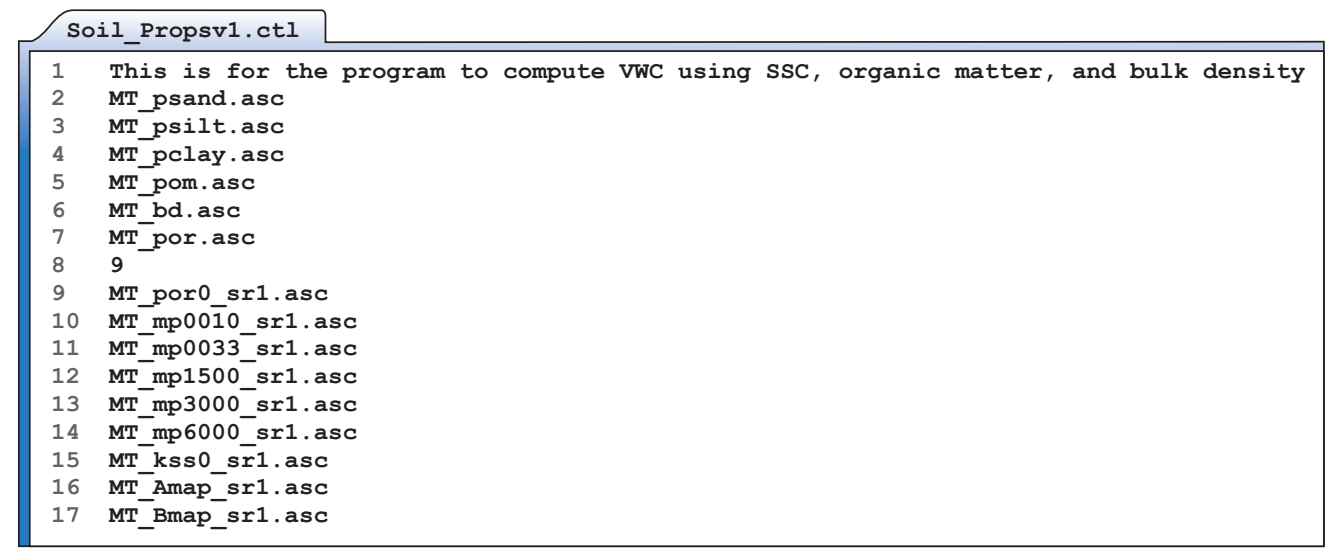

Figure 2.3. Control file for SoilPropsv1 (SoilPropsv1.ct)). (Abbreviations: VWC, volumetric water content; SSC, percentages of sand - silt - clay) 


\section{Obtain new climate files \\ Go to: https://prism.oregonstate.edu/ to download climate grids \\ Data is monthly in * ${ }^{*}$ bil or * ${ }^{*}$.asc format, for the US (conus) at $\sim 5$ kilometer $(\mathrm{km})$ resolution in geographic projection \\ Download precipitation, minimum and maximum air temperature \\ Set up directories, reproject climate files \\ Create three directories: US_5km_Teale,US_800m_Teale,CA_270m \\ Populate US_5km_Teale with downloaded climate files \\ Using ArcGIS (Python), reproject files to local projection (in this case, CA Teale Albers) \\ Downscale using Regridv3 \\ Set up Regridv3 control file to identify filenames for $5-\mathrm{km}$ and 800 meter $(\mathrm{m})$ digital elevation model (DEM) \\ - Clarify input and output filenames and directories \\ - Identify number of files to regrid \\ In DOS window, run Regridv3.exe to produce $800 \mathrm{~m}$ files in Teale projection for US domain \\ Set up Regridv3 control file to identify filenames for $800-\mathrm{m}$ and $270-\mathrm{m}$ DEMs \\ - Clarify input filenames and directory and output filenames and directory \\ - Identify number of files to regrid \\ In DOS window, run Regridv3.exe to produce 270-m files in Teale projection for CA domain \\ Calculate Potential Evapotranspiration with PET_Actualv1 \\ Set up PET_Actualv1 control file to identify tmx and tmn input filenames and pet output filenames for the number of months of climate files \\ Ensure that 12 months each of average monthly pet, tmn, and tmx are in the directory \\ In DOS window, run PET_Actualv1.exe to produce monthly PET for the updated climate files \\ Update BCMv8 with new climate and PET \\ Set up BCMv8 control file to update outfile names and date of water year run \\ Indicate directory location of new climate files \\ In DOS window, run BCMv8 to produce all new water balance variables}

Figure 2.4. Diagram of workflow for updating an existing Basin Characterization Model (version 8) with new climate files and potential evapotranspiration. (Abbreviations: asc, ASCII; bil, band interleaved by line; conus, contiguous United States; CA, California; DOS, Microsoft command-line interface, called Command Prompt; pet or PET, potential evapotranspiration; tmx and tmn, maximum and minimum air temperature)

\section{To Downscale PRISM Climate}

1. Download necessary monthly PRISM data for precipitation and minimum and maximum air temperature (http://www.prism.oregonstate.edu/)

a. To downscale from $4 \mathrm{~km}$ to $10 \mathrm{~m}$, the $10-\mathrm{m}, 270-\mathrm{m}$, $800-\mathrm{m}$, and 4-km DEMs are required.

b. Project the PRISM (.bil) raster to the DEM projection, then export as an ASCII text file (*.asc).

c. Be sure that the final ASCII file header of the DEM exactly matches the climate grid headers

2. Set up "Regridv3" control files (fig. 2.5) to downscale to required spatial resolution (for example, three steps to $10-\mathrm{m}$ from 4-km). It is critical to check output maps for any downscaling artifacts related to search radii. These are suggested steps and search radii:
a. From $4-\mathrm{km}$ to $800-\mathrm{m}$, search radius $=30,000$
b. From $800-\mathrm{m}$ to $270-\mathrm{m}$, search radius $=8,000$
c. From $270-\mathrm{m}$ to $10-\mathrm{m}$, search radius $=3,000$

3. Set up a downscaling batch file to copy ReGridv3 control files and run in sequence or run ReGridv3 individually for each step.

4. In ArcGIS, Python, R, or another geoprocessing software, project the downscaled rasters to match the DEM projection and export as an ASCII (*.asc) file. Make sure the header (Lines 1-6) exactly matches your project DEM (*.asc) file.

If grids such as climate or soils data are available at the desired cell size but are for a greater extent than the project DEM, ClipGridv1 can be used to extract data from larger grids to ensure the new files are the same size and extent as the DEM. The ClipGridv1 control file is shown in figure 2.6.

\section{Developing Snow-Parameter Maps}

Snow parameters can be set to a constant value in the control file or, for larger regions, can be spatially distributed across the domain and referenced in the control file. If there is no snow in the study area, the snow-parameter maps can be set to " 1 ," and other snow flags and parameters can be left at the default values. If there is snow in the study area, refer to the Snow-17 model documentation to develop calibrated snow parameters for the study area (Anderson, 2006).

Next is the method for developing spatially distributed snow accumulation, maximum melt factor, and minimum melt factor parameter grids. 


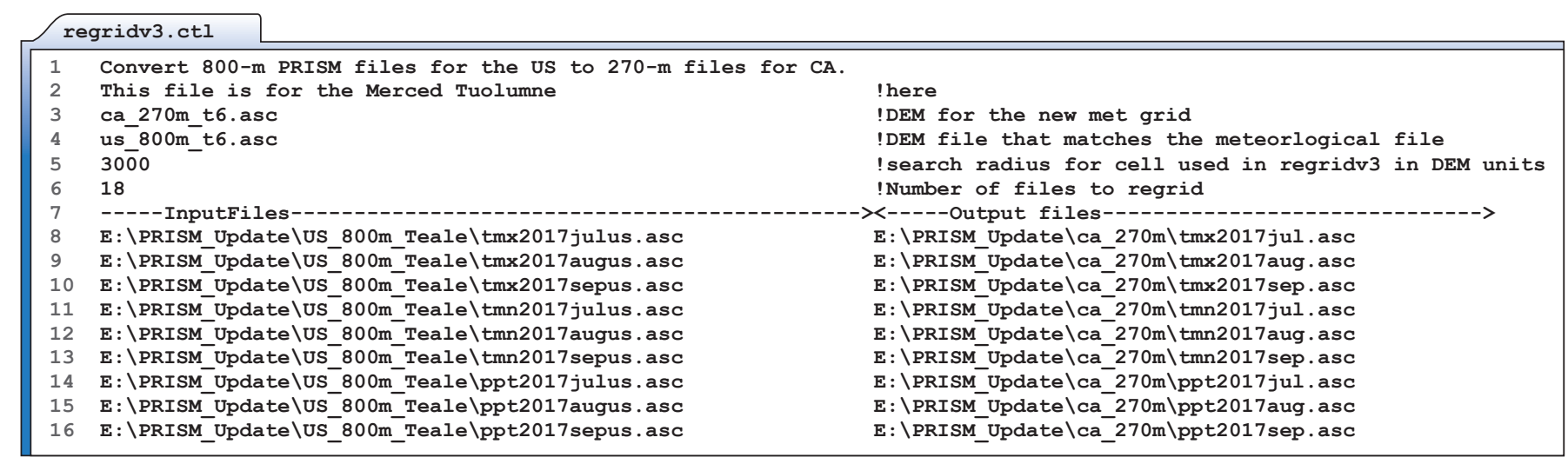

Figure 2.5. Control file for Regridv3 (Regridv3.ctl).

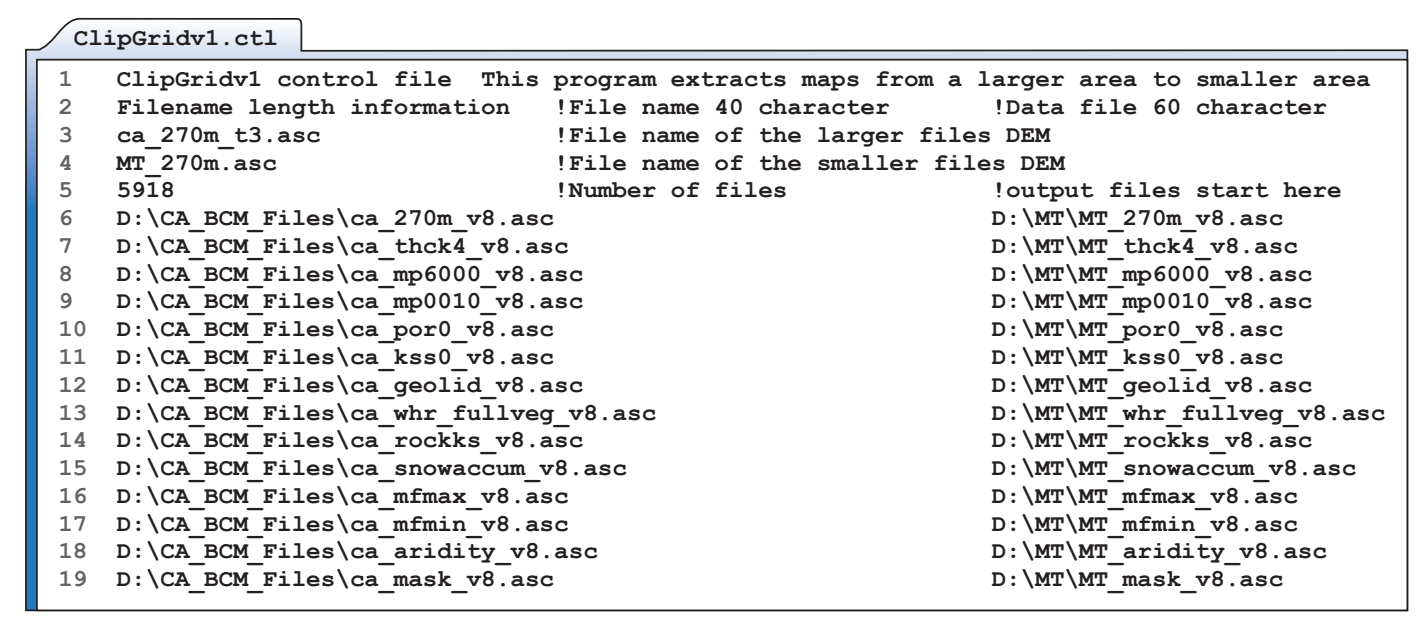

Figure 2.6. Control file for ClipGridv1 (ClipGridv1.ctl).

\section{To Develop Snow-Parameter Maps from Local Snow-Course Data}

1. Download snow-course or snow-pillow data from local or regional Websites (snow-course data are recommended when available because of having a larger measurement footprint, depending on the project DEM grid-cell size). Example data was downloaded from CA Dept. of Water Resources CDEC webpage: http:/cdec.water.ca.gov/snow/current/snow/.

2. Parameter values for the temperature (degrees $C$ ) at which precipitation becomes snow (usually between 1 and $4{ }^{\circ} \mathrm{C}$ ) and values for the maximum and minimum melt factors must be developed. The equation is a sine function with the maximum melt factor on June 21 and the minimum melt factor on December 21 (fig. 2.7).
3. Run BCM_Monthlyv8 using a basin file of point locations in the study area. Adjust parameter values to optimize snowpack (pck_mon.asc) match to observed data for each station (fig. 2.8). The month name of the snowpack file (that is, pckmar.asc) relates to the first day of the next month (that is, station observations on April 1st correlate with the snowpack file for March).

4. Choose the combination of parameters with the best fit of modeled to observed data for each station. In ArcGIS or Python, iteratively use geostatistics such as kriging/ cokriging, inverse distance weighting, or empirical Bayesian kriging to interpolate the best fit for each parameter across the study area. Cokriging was used for the California maps of snow accumulation, maximum melt factor, and minimum melt factor (fig. 2.9).

5. Export the three grids to ASCII text files and ensure that extent and map projection are the same as the project DEM by comparing headers in the ASCII file. 


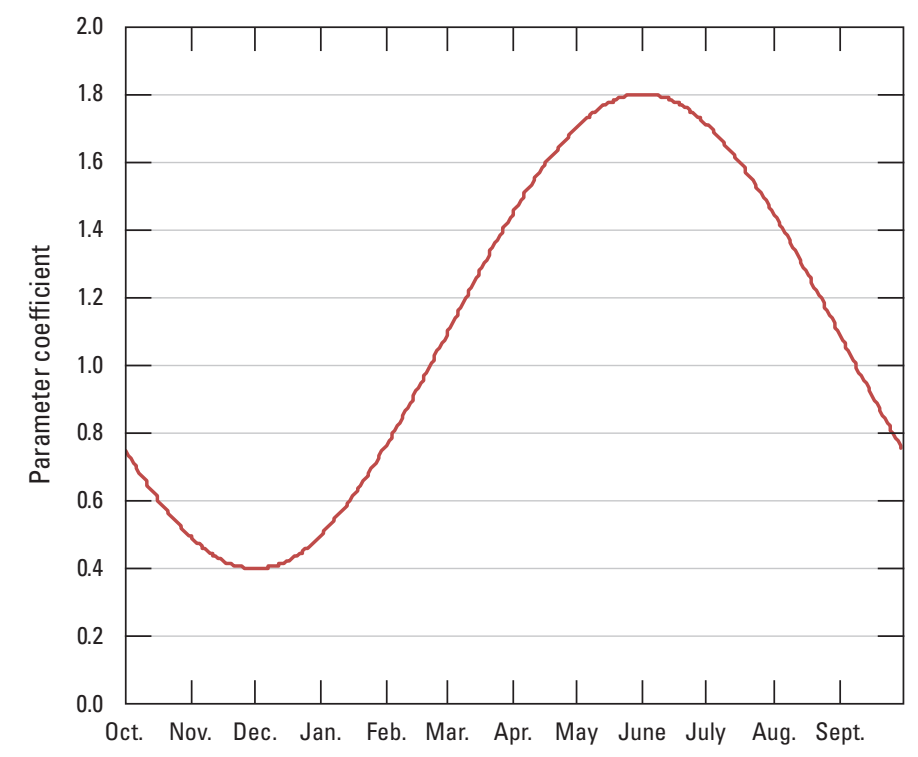

Figure 2.7. Sine function described by the maximum melt factor $(\operatorname{mfmax}=1.8)$ on June 21 and the minimum melt factor $(\mathrm{mfmin}=0.4)$ on December 21.

A

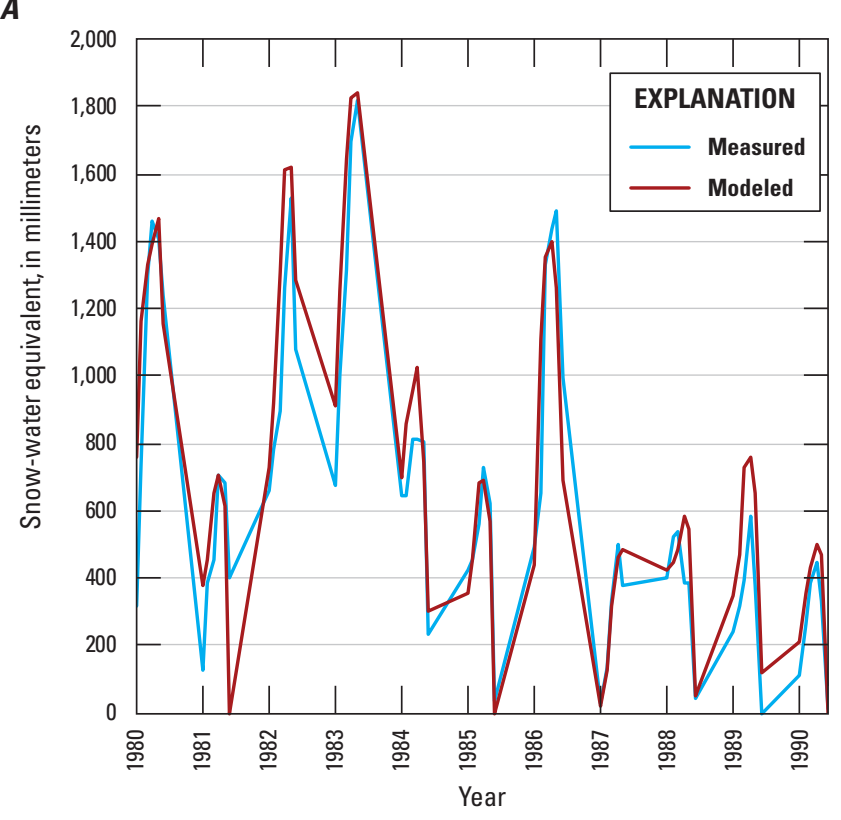

B

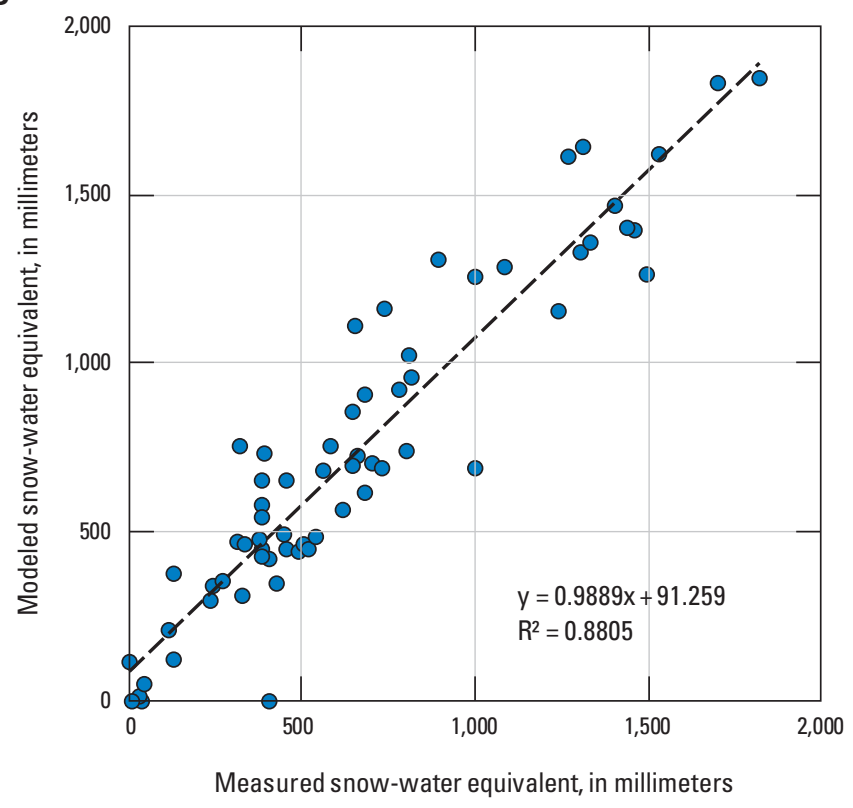

Figure 2.8. Measured and BCMv8-modeled snow-water equivalent (SWE) data from snow course shown as $A$, a time series from 1980 to 1991 , and $B$, a scatter plot with regression line. 
$\boldsymbol{A}$

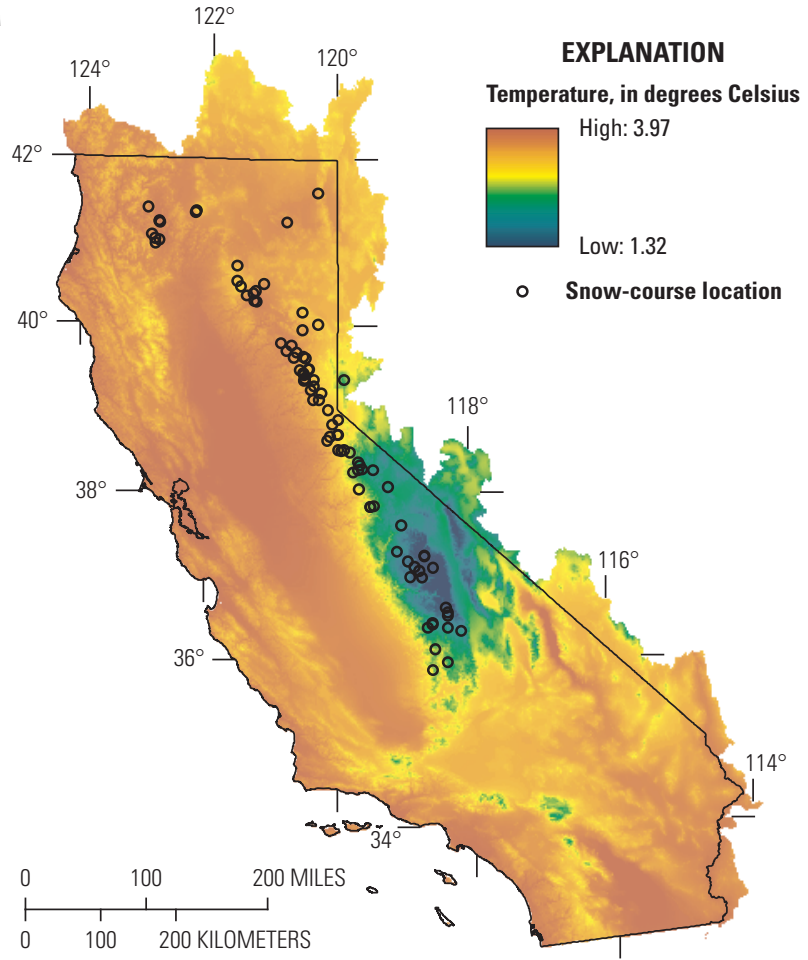

Base modified from U.S. Geological Survey digital data, various scales; Albers Equal Area Conic projection, standard parallels are $29^{\circ} 30^{\prime \prime}$ and $45^{\circ} 30^{\prime \prime}$; North American Datum of 1983

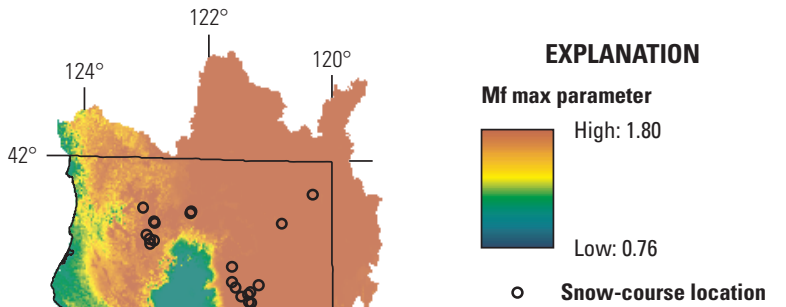

- Snow-course location

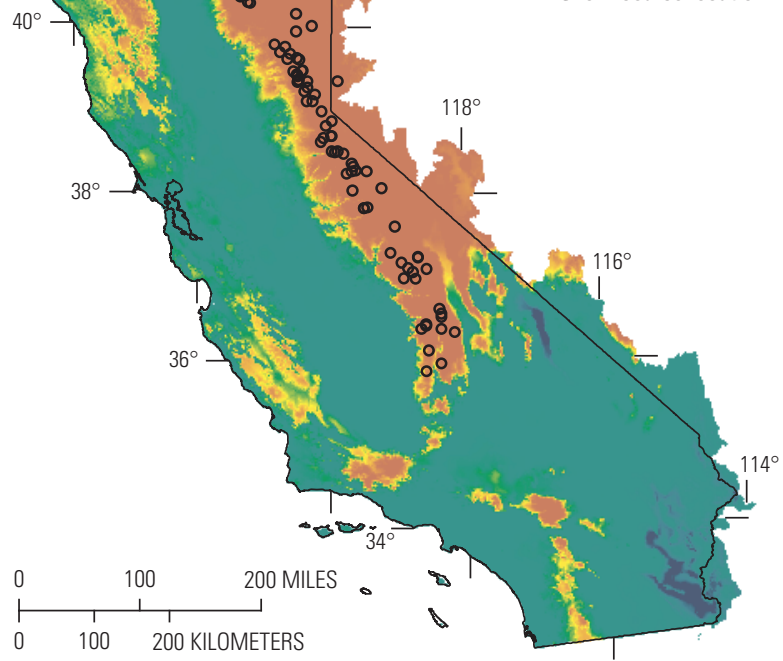

Base modified from U.S. Geological Survey digital data, various scales; Albers Equal Area Conic projection, standard parallels are $29^{\circ} 30^{\prime \prime}$ and $45^{\circ} 30^{\prime \prime}$ N North American Datum of 1983

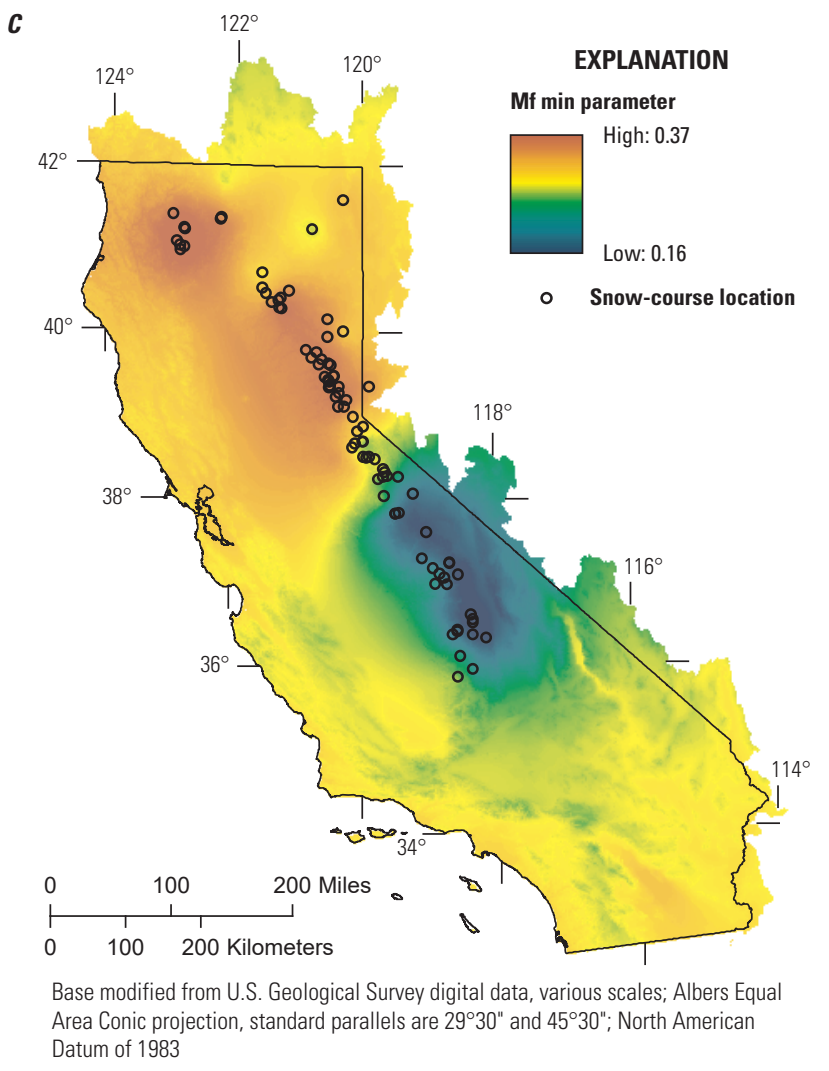

Figure 2.9. Geostatistical result using best-fit parameters for each station, where $A$, temperature at which snow accumulates (SnowAcc) used elevation; $B$, maximum melt factor (Mf max) used average minimum temperature; and $C$, minimum melt factor (Mf min) used elevation. 


\section{Developing Potential Evapotranspiration}

Developing monthly potential evapotranspiration (PET) requires a sequence of codes and analyses, starting with calculations of daily clear-sky solar radiation using topographic shading and atmospheric parameters, which are calibrated to cloudiness using station data to develop a long-term average monthly actual PET. This result is combined with monthly air temperatures to calculate PET for each historical or future month. See figure 2.10 for a workflow sequence of processing steps to guide the development of input files and the calculation of the energy balalnce to determine a calibrated cloudy sky monthly potential evapotranspiration.

\section{Calculate topographic shading using Skyviewv1}

Obtain project DEM

Open Skyviewv1 control file and define search radius that is dependent on local topography and distance to mountains that block solar radiation

In DOS window run Skyviewv1 to produce 36 map files (one for each 10-degree increment) of the angle of the topography at the horizon, and files for slope and aspect

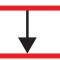

\section{Calculate latitude and longitude for each grid cell using Mklatlonv1}

Develop Mklatlonv1 control file

- Identify DEM and output file names

- Using ArcGIS provide the latitude and longitude (decimal degrees and meters) of the four corners of the digital elevation model (DEM)

In DOS window run Mklatlonv1 to create a file of latitudes and a file of longitudes for each grid cell

\section{Develop input files for calculating solar radiation and PET using Solinpv1}

Develop Solinpv1 control file

o Identify all input filenames: DEM, Skyview output filename, latitude, longitude, slope and aspect files names from Mklatlonv1

- Include 36 angle files from Skyviewv1 in directory

In DOS window, run Solinp.exe to produce necessary input file for SolPET6

\section{Calculate clear sky solar radiation and average monthly PET using SoIPET6}

Develop control file for SoIPET6

- Identify input file developed by Solinpv1

- Identify output filenames, day of year to start and end, time step in hours, and Central meridian longitude in degrees

Check that 12 months each of tmnavemmm. asc and tmxavemmm. asc are in directory

In DOS window, run SoIPET6 to calculate 4 output files, clear sky solar radiation, ground heat flux, net radiation, and PET for each of 12 months

\section{$\downarrow$}

\section{Determine long-term cloudy sky PET}

Collect data for reference evapotranspiration (ETo) from stations in modeling domain

For each station develop a monthly scaling factor by dividing measured ETo by modeled PET

In ArcGIS, use geostatistics and focal statistics to develop a spatially distributed map of the scaling factor for each month and multiply each monthly scaling factor by the monthly clear sky PET to develop the long-term cloudy sky PET for each month

\section{$\downarrow$}

\section{Calculate monthly cloudy sky PET using PET_Actualv1}

Set up PET_Actualv1 control file to identify tmx and tmn input filenames and pet output filenames for the number of months of climate files

Ensure that 12 months each of average monthly pet from SolPET, and tmn, and tmx are in the directory In DOS window, run PET_Actualv1.exe to produce monthly PET for the updated climate files

Figure 2.10. Diagram of workflow for developing files and calculating the energy balance and monthly potential evapotranspiration. (Abbreviations: ave, average; DOS, Microsoft command-line interface, called Command Prompt; mmm, month identifier in 3-character format [JAN to DEC]; tmn and tmx, minimum and maximum air temperature; PET or pet, potential evapotranspiration) 


\section{To Develop Monthly PET}

1. To calculate the angle of the horizon in 36 directions on the basis of topography to determine topographic shading and the resulting percentage of hemisphere for each grid cell, develop a control file for Skyviewv1 (Skyviewv1.ctl; fig. 2.11), which requires the project DEM, output filenames, and a user defined search radius dependent on local topography and distance to mountains that block solar radiation. Run Skyviewv1. exe. This code creates 36 files (one for each 10-degree increment) of the angle of the topography at the horizon and files for slope and aspect.
2. To calculate the latitude and longitude for each grid cell to properly calculate clear-sky solar radiation, develop a control file for Mklatlonv1 (Mklatlonv1.ctl), which requires the project DEM, the four corners of your gridded DEM in latitude and longitude (decimal degrees), and in the map projection of your project DEM (in meters; fig. 2.12). Run Mklatlonv1.exe. This creates a file of latitudes and a file of longitudes.

3. To create the input file for calculating daily clear-sky solar radiation and PET, develop a control file for Solinpv1 (Solinpv1.ctl), which requires the DEM and all files from steps 1 and 2 (fig. 2.13) and results in the necessary input file.

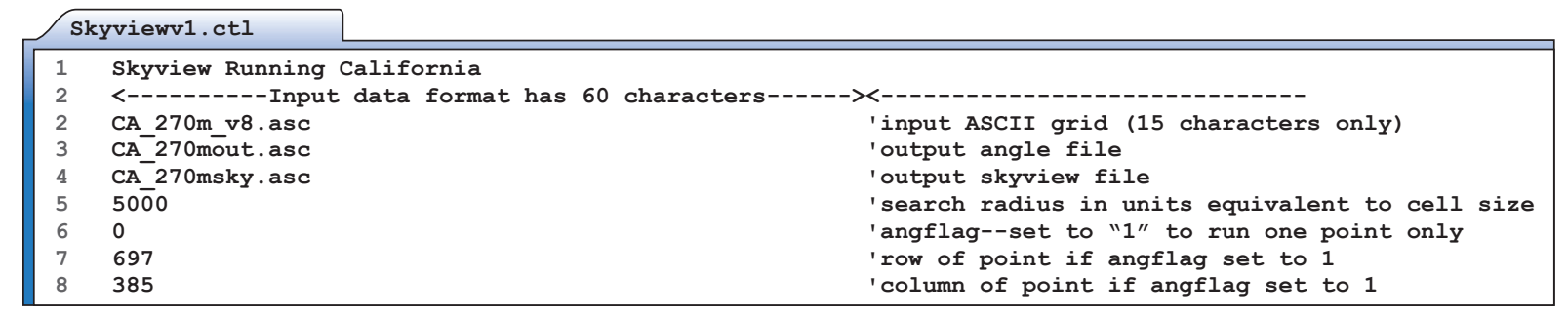

Figure 2.11. Control file for Skyviewv1 (Skyviewv1.ctl).

\begin{tabular}{||ll|ll|}
\hline mklatlonv1.ctl & \\
\hline 1 & This is the latitude and longitude conversion file \\
2 & CA_270m_t2.asc & 'demfile & \\
3 & CA_270lat.asc & 'latfile & \\
4 & CA_270lon.asc & 'lonfile & \\
5 & $-1 \overline{2} 2.262$ & 'westlon left \\
6 & -121.129 & 'eastlon right \\
7 & 40.700 & 'northlat top \\
8 & 39.738 & 'southlat bottom \\
9 & -191165.836 & 'left & \\
10 & -96665.836 & 'right & \\
11 & 300496.666 & 'top & \\
12 & 191956.666 & 'bottom & \\
\hline
\end{tabular}

Figure 2.12. Control file for Mklatlonv1 (Mklatlonv1.ctl). (Abbreviations: dem, digital elevation model; lat, latitude; lon, longitude)

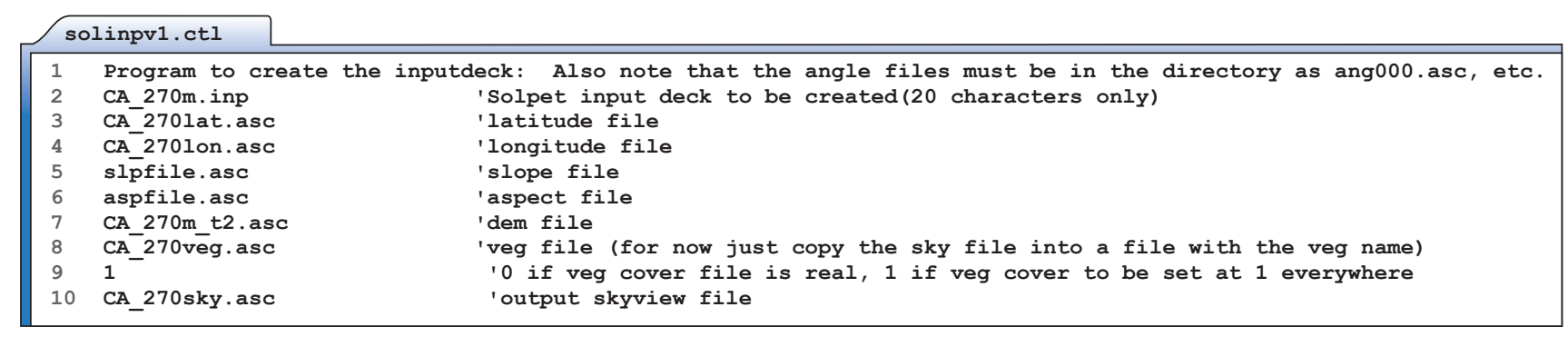

Figure 2.13. Control file for Solinpv1 (Solinpv1.ctl). (Abbreviations: dem, digital elevation model; veg, vegetation) 
4. To calculate clear-sky solar radiation and PET, develop a control file for SolPET6 (SolPET6.ctl), which requires the input file created in step 3, DEM, average long-term minimum and maximum air temperatures (name files using 3-character identifiers for each month; that is, January files named TMXAVEJAN.asc and TMNAVEJAN.asc), output filenames for clear-sky solar radiation, ground heat flux, net radiation, and PET (fig. 2.14), day of year to begin monthly run and day of year to end monthly run. Standard atmospheric parameters are in the model and described in Flint and Childs (1987). Develop 12 control files, one for each month with correct beginning and ending days. Run SolPET6, which generates four outfiles for each of 12 months.

5. To determine long-term cloudy-sky PET for each of 12 months, collect data for reference ET from stations in your modeling domain (for example. California Irrigation Management Information System, CIMIS, at https://cimis.water.ca.gov/; Arizona Meteorological
Network, AZMET, at https://cals.arizona.edu/azmet/ phxturf.html) and calculate a long-term monthly measured value of reference evapotranspiration (ETo) for each station.

6. For each station develop a monthly scaling factor by dividing measured ETo by modeled PET.

7. In ArcGIS, use geostatistics and focal statistics to develop a spatially distributed map of the scaling factor. Multiply each monthly scaling-factor map by the monthly clear-sky PET to develop the long-term cloudy-sky PET for each month.

8. To calculate monthly cloudy-sky PET as input to the BCMv8, develop a control file for PET_Actualv1 (PET_Actualv1.ctl; fig. 2.15), which requires monthly minimum and maximum air temperature and output filenames to calculate monthly PET. Run PET_Actualv1, which generates monthly files of PET to be used as input to BCM_Monthlyv8.

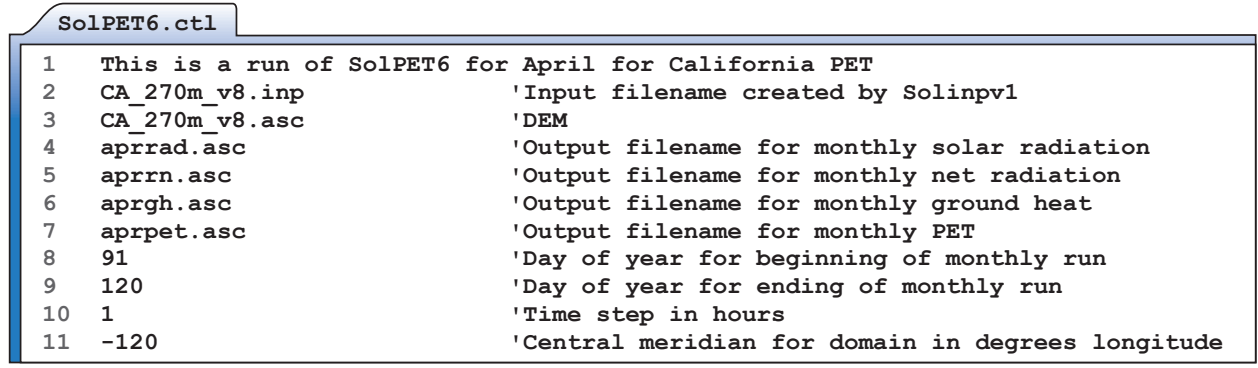

Figure 2.14. Control file for SoIPET6 (SolPET6.ctl). (Abbreviations: DEM, digital elevation model; PET, potential evapotranspiration)

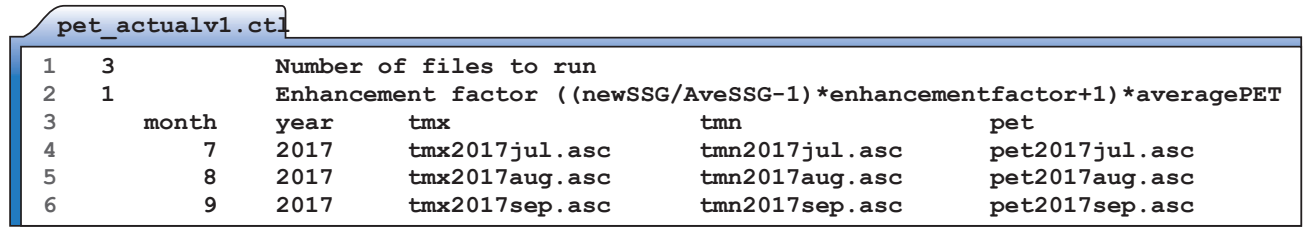

Figure 2.15. Control file for PET_Actualv1 (PET_Actualv1.ctl). (Abbreviations: tmn and tmx, minimum and maximum air temperature; PET or pet, potential evapotranspiration) 


\section{Developing the Aridity Index (Optional) To Develop Vegetation Maps}

Aridity index is calculated as annual precipitation divided by annual potential evapotranspiration.

\section{Developing a Mask (Optional)}

An optional mask can be used to remove areas from the summarizing calculations and the output grids. The mask must have the same extent and map projection as the DEM and defines masked-out areas as "noData" (-9999, or as defined in each ASCII file), where a value of " 1 " is unmasked.

\section{Developing Vegetation Maps and $K_{v}$}

Obtain or develop mapped vegetation grid (for example, National Land Cover Database, NLCD, at https://www.mrlc.gov/; Fire Resource and Assessment Program, FRAP, at https://egis.fire.ca.gov/arcgis/rest/ services/FRAP/fveg_WHRTYPE/MapServer/layers; California Vegetation Classification and Mapping Program, at https://www.wildlife.ca.gov/Data/VegCAMP). Clip to the study area and convert to the projection, extent, and grid-cell size of the project DEM.

If using Reitz and others (2017) estimates of actual evapotranspiration (ETa) for the United States available at 1-km resolution (https://doi.org/10.5066/F7QC02FK) for calibration and the project DEM has a resolution of less than 1 $\mathrm{km}$, it is recommended to revise the vegetation map to remove cells that do not have the same vegetation type covering most of each 1-km area. The purpose of this is to sample ETa using a vegetation grid that is finer than $1 \mathrm{~km}$ and that adequately represents the ETa for each vegetation type in each cell, without mixed vegetation types. This is done using the ETa maps that have been resampled to $270-\mathrm{m}$, and the following example is for a $270-\mathrm{m}$ vegetation map.
1. Resample 30-m vegetation map to $270-\mathrm{m}$ resolution using the majority resampling technique in ArcGIS or Python. This map is called "fullveg.asc" in the input file list (fig. 2.16).

2. In ArcGIS, group all vegetation-type cells that match by using the four sides of the cell and its corners to define a connected group.

3. Exclude any regions that are less than 20 cells (about 1.5 square kilometers $\left[\mathrm{km}^{2}\right]$ ) in size from the analysis. This map is called "partveg.asc" in the input file list.

4. Resample the ETa maps to 270-m resolution using the cubic convolution resampling method.

\section{To Develop $K_{v}$}

1. Extract ETa data from Reitz and others (2017) or other gridded datasets for each vegetation type. This can be done in ArcGIS or by using R scripts or BasinExtractv1.

2. Extract PET for each vegetation type or run BCM monthlyv8 with partveg.asc as the basin file to obtain monthly time series of PET for 2000-15.

3. In Microsoft Excel, calculate $\mathrm{K}_{\mathrm{v}}$ by dividing the average monthly ETa for the period by the average monthly PET for each vegetation type (fig. 2.17). Add final monthly $\mathrm{K}_{\mathrm{v}}$ for each vegetation type to LOOKUP table 2 in BCM_Monthlyv8.ctl.

4. Refer to local vegetation calibration instructions in appendix 3 to develop remaining vegetation parameters to match BCMv8 AET to ETa. 


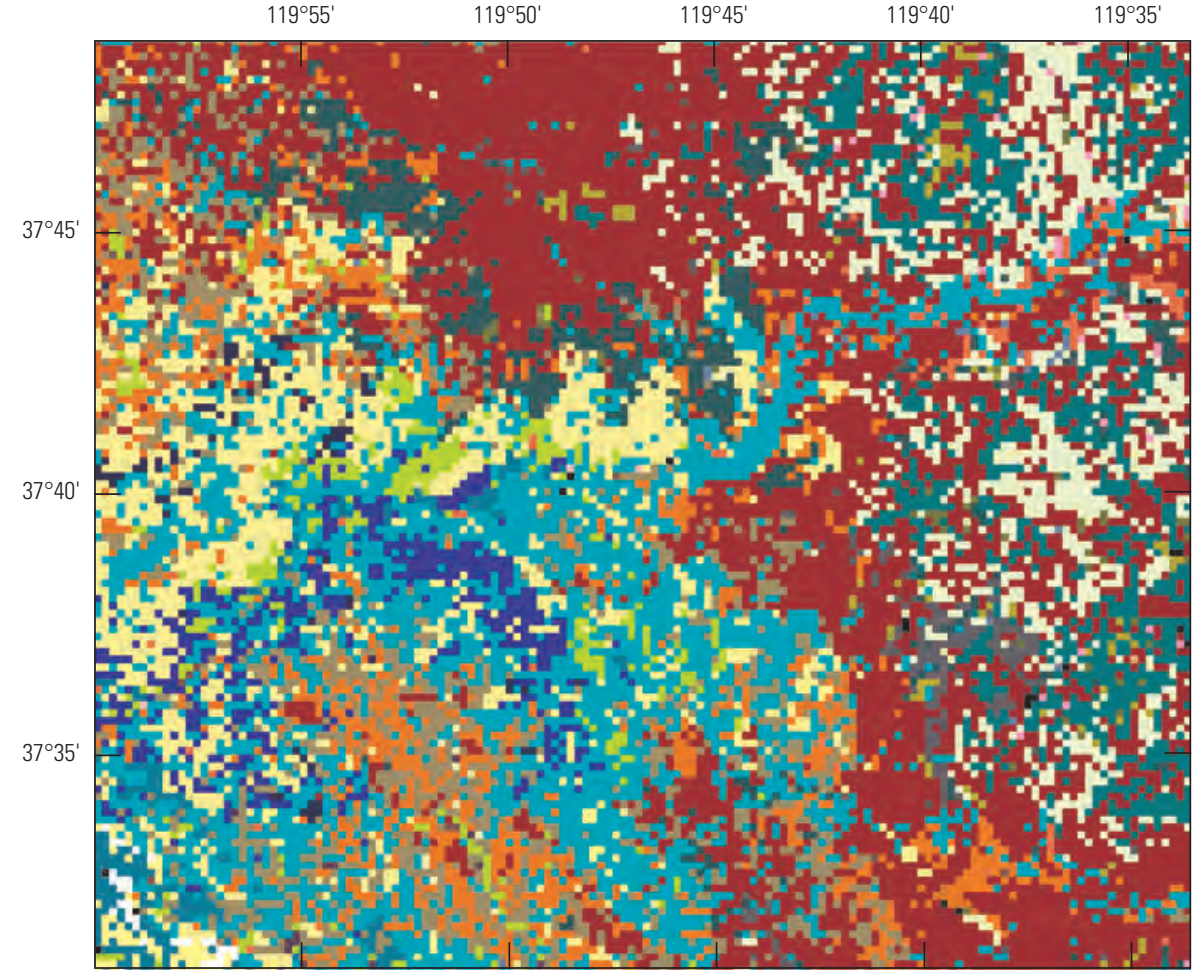

Base modified from U.S. Geological Survey digital data, various scales; Albers Equal Area Conic projection, standard parallels are $29^{\circ} 30^{\prime \prime}$ and $45^{\circ} 30^{\prime \prime}$; North American Datum of 1983

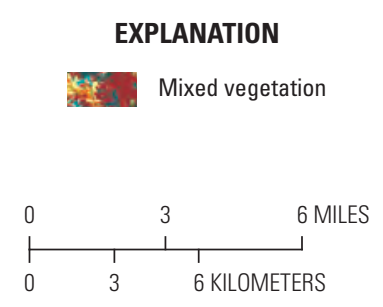

$\boldsymbol{B}$

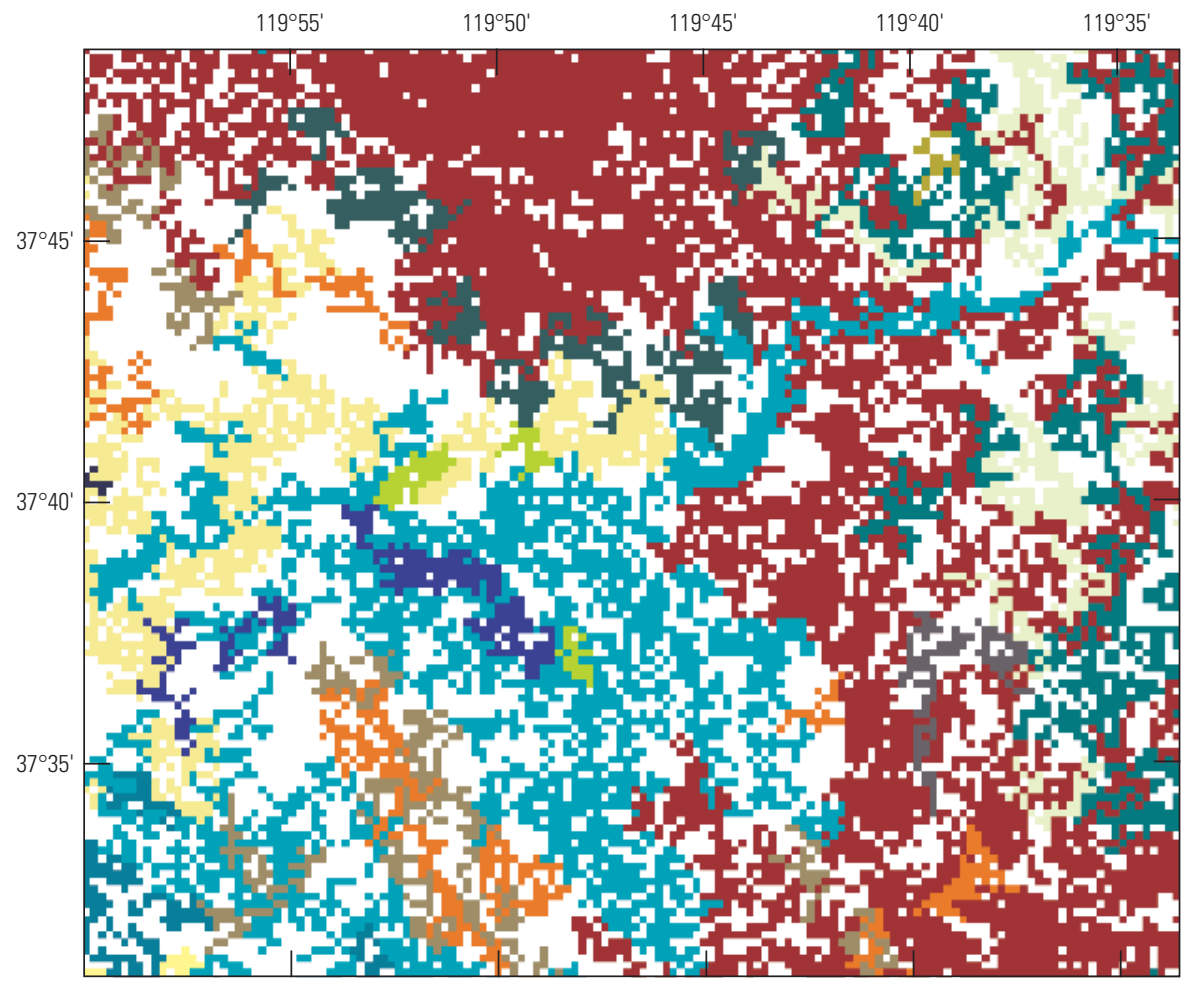

Base modified from U.S. Geological Survey digital data, various scales; Albers Equal Area Conic projection, standard parallels are 29०30" and 45³0"; North American Datum of 1983

\section{EXPLANATION}

EI

Mixed vegetation cell meeting the criteria of at least 20 contiguous grid cells

No data—cell not meeting criteria of at least 20 contiguous grid cells

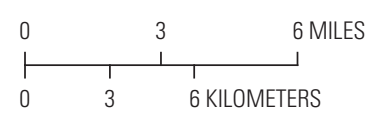

Figure 2.16. Gridded vegetation types in the central Sierra Nevada for $A$, fullveg and $B$, partveg. 


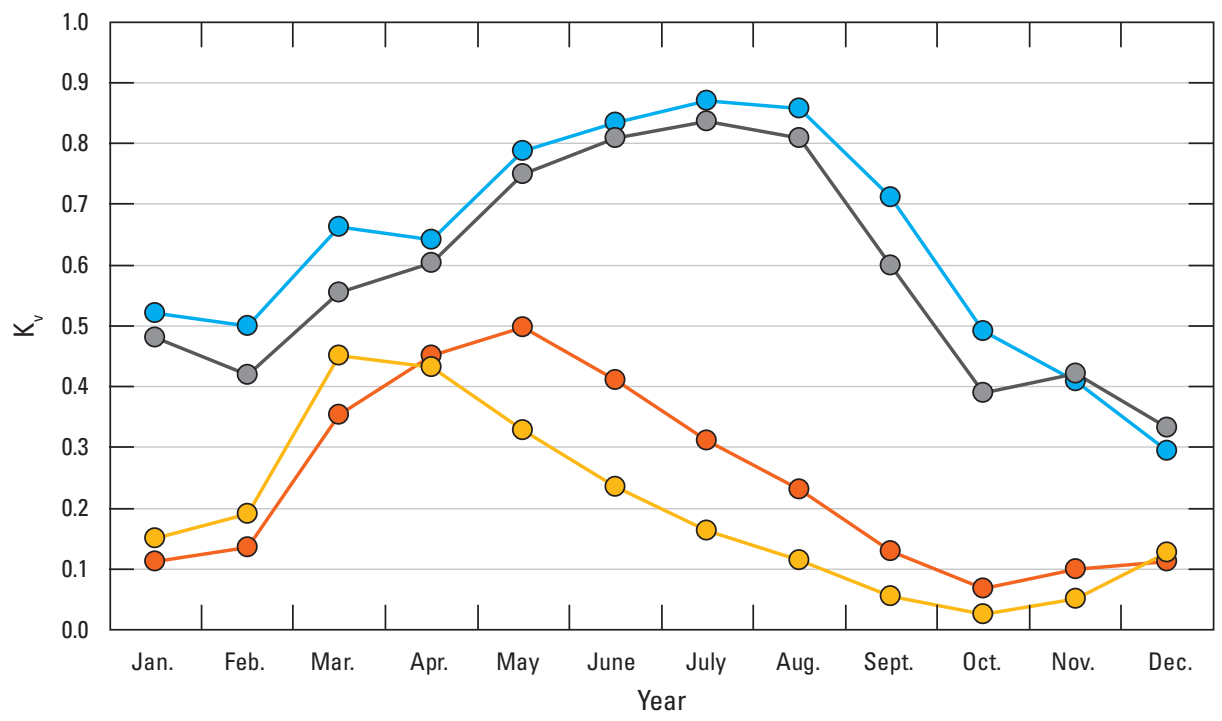

EXPLANATION

- D- Douglas fir

- - Blue oak woodland

- - Montane hardwood-conifer

- - Annual grassland

Figure 2.17. Examples of average monthly $K_{v}$ for four vegetation types, water years 2001-15. 


\section{Calculating the Water Balance with the BCMv8}

\section{To Calculate the Water Balance for Project Area}

1. Develop control file for BCM_Monthlyv8 (BCM_ Monthlyv8.ctl), which requires all layer files necessary for selected switches and climate files for the desired period of analysis. Check to make sure all input files and climate grids are in the same folder. See main-body section "Software Options and the Control File" to determine appropriate setting for switches and necessary files and include name of basin file and table file that define the areas summarized in the monthly and yearly outfiles. List years for which model is to print out maps of output.

2. Open a command prompt window and type BCM Monthlyv8 (fig. 2.18), which results in monthly and yearly outfiles and maps as directed.

3. Calibrate model as desired following steps in appendix 3.

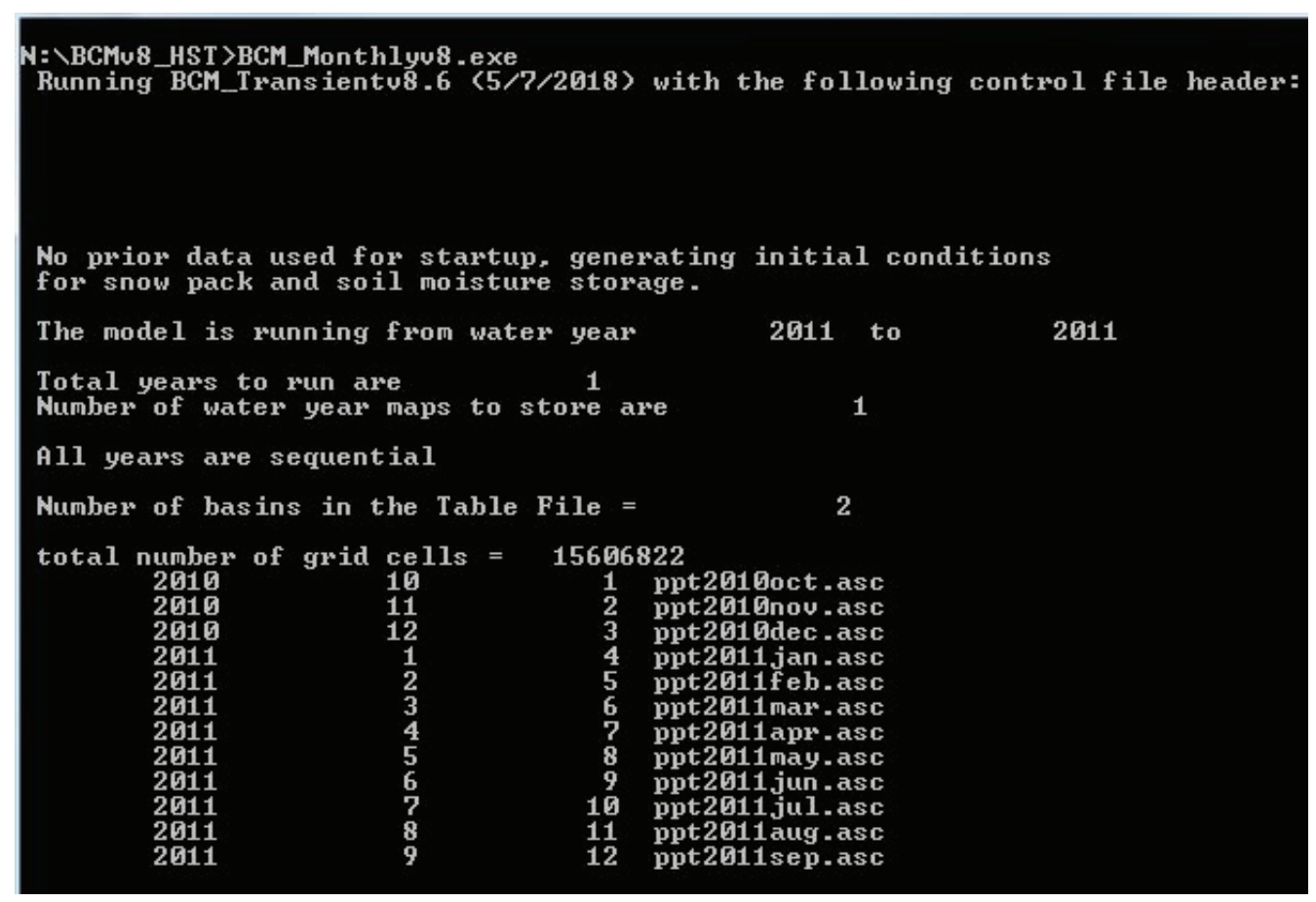

Figure 2.18. The DOS command prompt window with command line showing execution of command to run BCM_monthlyv8. Top line indicates entry of "BCM_Monthlyv8" to start model run; next 8 lines are code output giving details on the run; and the last 12 lines are outputs of the year, month identity (numeric), sequential month count, and initial file name for each month as it is read and processed. 


\section{Appendix 3. Procedure for Local Calibration}

This procedure allows a user to develop a $\mathrm{BCMv} 8$ from study locations in California at a 270-m grid-cell resolution and perform a local calibration that only takes into consideration geology and vegetation types of the local region. The examples used refer to the Merced -Tuolumne local region (acronym "MT" in file names listed in control files).

\section{Setting Up a California Submodel and Local Calibration}

These are required files for submodel:

1. Digital elevation model (DEM) for new project area.

2. Basin file with calibration basins or sensor locations.

3. All required California layer files listed in table 2 and appendix 1 and optional files depending on switches used in control file.

4. California monthly climate files for desired simulation period (minimum and maximum air temperature, precipitation, potential evapotranspiration).

5. California monthly grids of $\mathrm{K}_{\mathrm{v}}$ for $2000-15$ (PET/ ETa; ETa from Reitz and others, 2017) for actual evapotranspiration calibration.

6. Available calibration data (streamflow, snow sensor/ snow course data).

7. CalBasins_v8_template.xlsx spreadsheet for calibration of model results to streamflow.

FORTRAN codes with control files (all codes are run in a command prompt window in the same directory as the model files and control file by typing in the name of the executable file):

1. ClipGridv1 (ClipGridv1.exe) - clips any ASCII grid to a smaller ASCII grid file to match a DEM.

2. BasinExtractv1 (BasinExtractv1.exe) - extracts time-series data from grids by adding or averaging all cells with the same unique identifier.

3. BCM_Monthlyv8 (BCM_Monthlyv8.exe) - Basin Characterization Model, version 8.

\section{Developing Input Files}

The basin file is developed to summarize the spatial data by averaging (temperature) or summing (all water variables) for each month for integer-defined areas, such as all grid cells upstream from a streamgage or reservoir, watersheds, geopolitical boundaries, or for gridded vegetation types, in order to calculate a monthly and water year time series of all input and output variables. This file can be used to extract the DEM to be the basis for clipping all other input files and climate files.

\section{To Develop Basin File and DEM}

1. Develop the study-area shapefile for an area of interest in California by starting with a shapefile of watershed boundaries and combine or edit according to calibration streamgages and include all contributing area upstream from each streamgage.

2. Using the study-area shapefile, extract the project DEM from the California 270-m DEM. Alternatively, extract a project DEM for the entire square extent covering the area of interest.

3. Create basin file grid on the basis of a unique basin identifier (integer only; see fig. $2.2 A$ and $B$ ).

4. Convert grid to ASCII text file and ensure extent and projection are exactly the same as the California 270-m DEM by comparing headers in the ASCII file (fig. $2.2 C$ and $E$ ).

5. Create a table text file (*.tbl; fig. $2.2 F$ ) including unique identifier and description or name of each basin or location. The BCMv8 output maps print output data for grid cells where there is a basin identifier corresponding to those in the table file.

\section{To Clip Local Climate and Input Layer Files from California Dataset}

1. Use ClipGridv1 master control file (fig. 3.1).

2. Edit name of project DEM (line 4).

3. Edit the output file names and directory.

4. Delete all lines of climate not required for the simulation period.

5. Open command prompt in location of control file and run ClipGridv1 to extract all climate and layer files that exactly match the project DEM. 


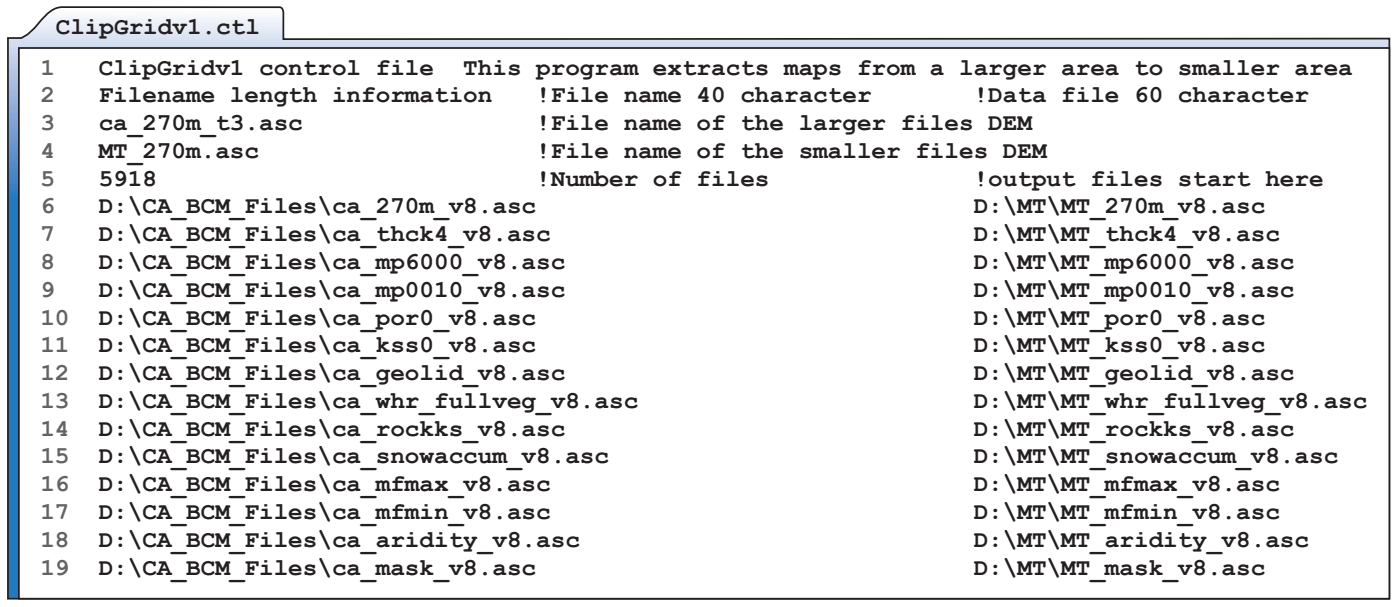

Figure 3.1. Control file for ClipGridv1 (ClipGridv1.ctl). (Abbreviation: DEM, digital elevation model)

\section{Calibrating Actual Evapotranspiration for Local Model Domain}

Vegetation parameters are developed and calibrated using actual evapotranspiration (ETa) and modeled AET from the BCMv8. Comparisons of AET are done using a local vegetation file (partveg.asc) that has been processed to eliminate areas of heavily mixed vegetation to represent the AET for a given vegetation type.

\section{To Develop New K}

1. Extract monthly time series of ETa for January 2000December 2015 for each vegetation type from California dataset using the FORTRAN code BasinExtractv1. Set up the BasinExtractv1 control file (fig. 3.2) with the name of the output text file, the partveg.asc basin file, the partveg table file (partveg.tbl) that identifies the unique vegetation type ID and name, and the list of monthly ETa files from which to extract.

2. Run BasinExtractv1 in a command prompt window.

3. Copy BasinExtract outfile from step 2 into a Microsoft Excel spreadsheet.

4. Run BCM_Monthly_v8 with partveg.asc as the basin file for water years 2000-15 to obtain time series of PET for each vegetation type.
5. Copy the BCM Monthlyv8 outfile into the Microsoft Excel spreadsheet from step 3 and summarize the PET into average monthly for the period of record. Divide average ETa by PET to develop $\mathrm{K}_{\mathrm{v}}$ for each vegetation type for each month.

6. Copy $\mathrm{K}_{\mathrm{v}}$ into BCM_Monthlyv8 control file in LOOKUP table 2 for each vegetation type.

7. Run BCM_Monthlyv8 with new $\mathrm{K}_{\mathrm{v}}$ to calculate AET to be compared with ETa.

8. Adjust rooting depth in LOOKUP table 2 to match average magnitude of ETa (figs. 3.3, 3.4).

9. If necessary to match the climatic variability of ETa, adjust the growth factors in LOOKUP table 2 (table 6). Figure 3.5 illustrates the effect of this adjustment for one vegetation type, annual grasslands, that is sensitive to annual variations in precipitation. For reference, the results with no adjustment to growth parameters, that is, using monthly average $\mathrm{K}_{\mathrm{v}}$, are graphed in figure $3.5 \mathrm{~A}$. Adjustments were made to UpLimit and DnLimit to bracket the highest peak month and lowest peak month with multipliers that are more and less than the average value. In this case, the UpLimits were selected to match the ETa peaks in water years 2005, 2006, and 2010 by an increase of about 60 percent (UpLimit of 1.6), and the 6-7 water years with low ETa values had DnLimits of about 0.75 . UpRates and DnRates are intended to calculate the precipitation scaler for each month that is then multiplied by the $\mathrm{K}_{\mathrm{v}}$ for that month (fig. 3.5B). Additional vegetation-parameter guidance can be found in the "Calibration Tools" section of the main body. 


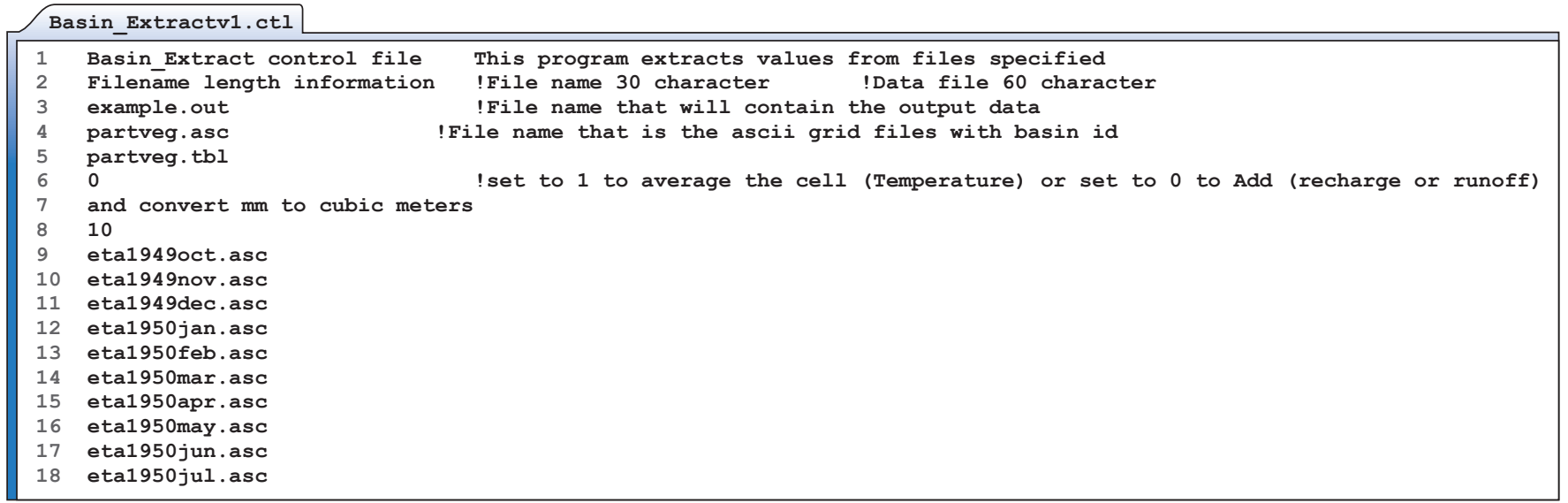

Figure 3.2. Control file for BasinExtractv1 (BasinExtractv1.ctl). (Abbreviation: mm, millimeters)

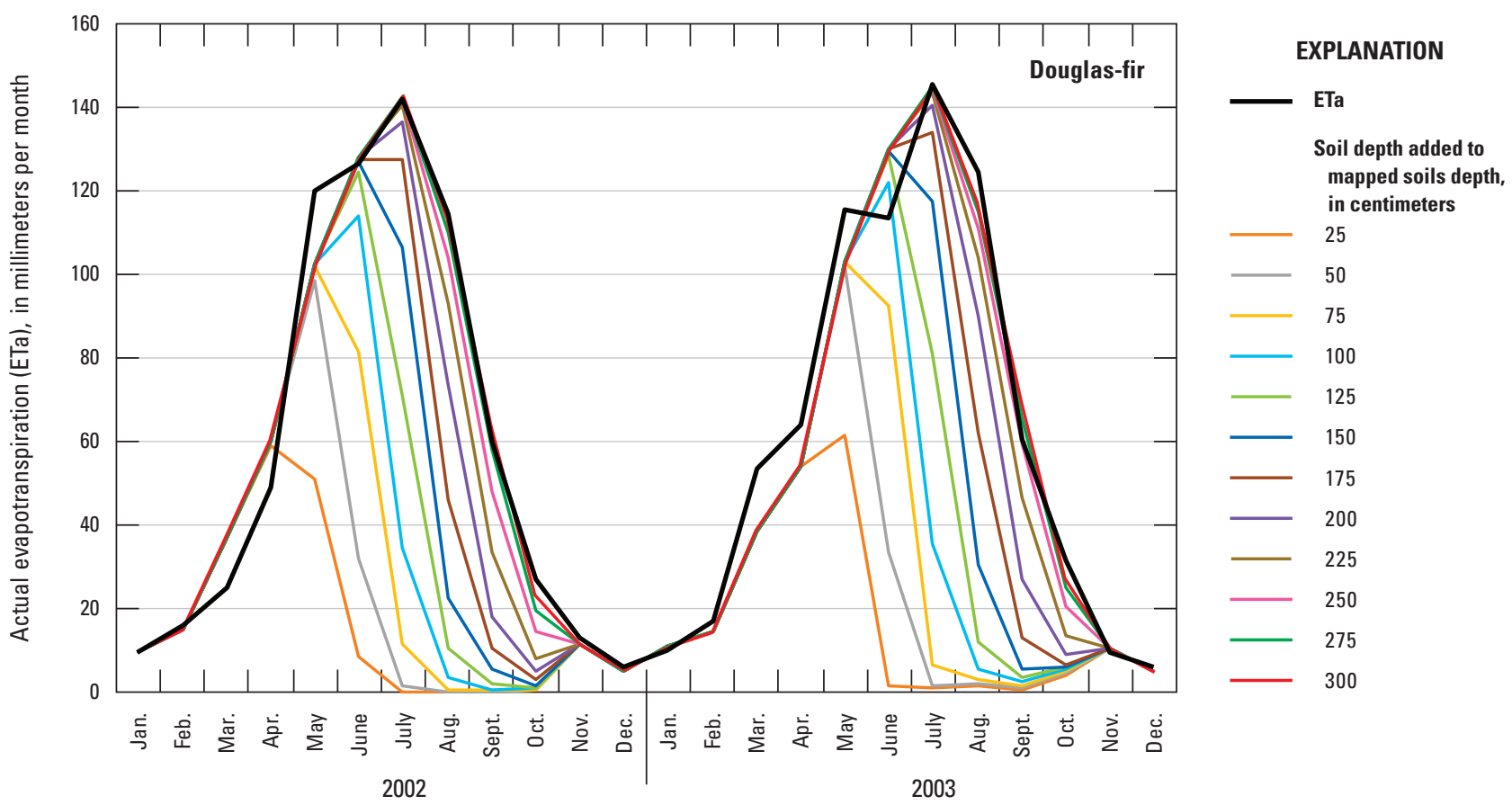

Figure 3.3. Adjustments to the RootDepth parameter to match average actual evapotranspiration (ETa) for one selected vegetation type (Douglas fir). 


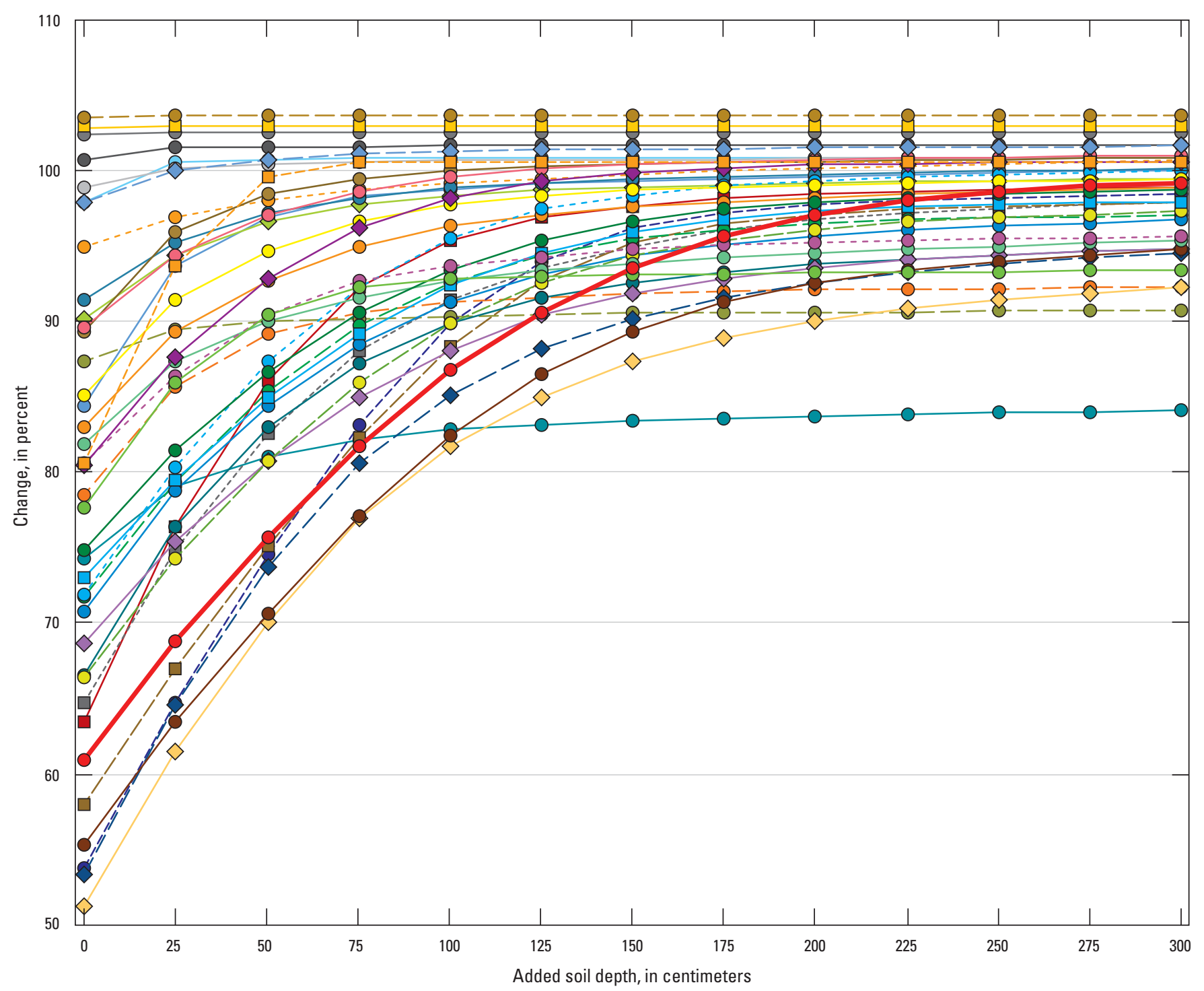

\begin{tabular}{|c|c|c|c|c|c|c|c|}
\hline \multicolumn{8}{|c|}{ EXPLANATION } \\
\hline-0 & Alpine-dwarf shrub & $-\diamond-$ & Chamise-redshank chaparral & 0 & Lodgepole pine & -0 & Red fir \\
\hline$--0-$ & Annual grassland & - & Coastal scrub & 0 & Low sage & 0 & Subalpine conifer \\
\hline$\multimap$ & Alkali desert scrub & 0 & Desert scrub & $\diamond$ & Mixed chaparral & $-\diamond-$ & Sagebrush \\
\hline$=0-$. & Aspen & $\square-$ & Desert succulent shrub & - & Montane chaparral & - & Sierran mixed conifer \\
\hline- & Barren & 0 & Desert wash & $-0-$ & Montane hardwood-conifer & $--0-\cdot$ & Valley oak woodland \\
\hline- & Bitterbrush & $\diamond$ & Eastside pine & $\longrightarrow$ & Montane hardwood & $\sim$ & White fir \\
\hline$--0--$ & Blue oak-foothill pine & 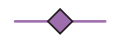 & Jeffrey pine & 0 & Perennial grassland & $--\square--$ & Eucalyptus \\
\hline$\square-$ & Blue oak woodland & $-0-$ & Joshua tree & - & Pinyon-juniper & 0 & Rock cliff scree \\
\hline$---\square--$ & Coastal oak woodland & -0 & Juniper & $-\square-$ & Ponderosa pine & -0 & Douglas fir \\
\hline$-\square--$ & Closed-cone pine-cypress & $-0--$ & Klamath mixed conifer & $--0-\cdot$ & Redwood & & \\
\hline
\end{tabular}

Figure 3.4. Relation between soil depth (added to mapped RootDepth) and change in model-estimated actual evapotranspiration for all nonirrigated vegetation types, illustrating that optimum depths for Douglas fir achieved about a 95 percent match to actual evapotranspiration. 
$\boldsymbol{A}$

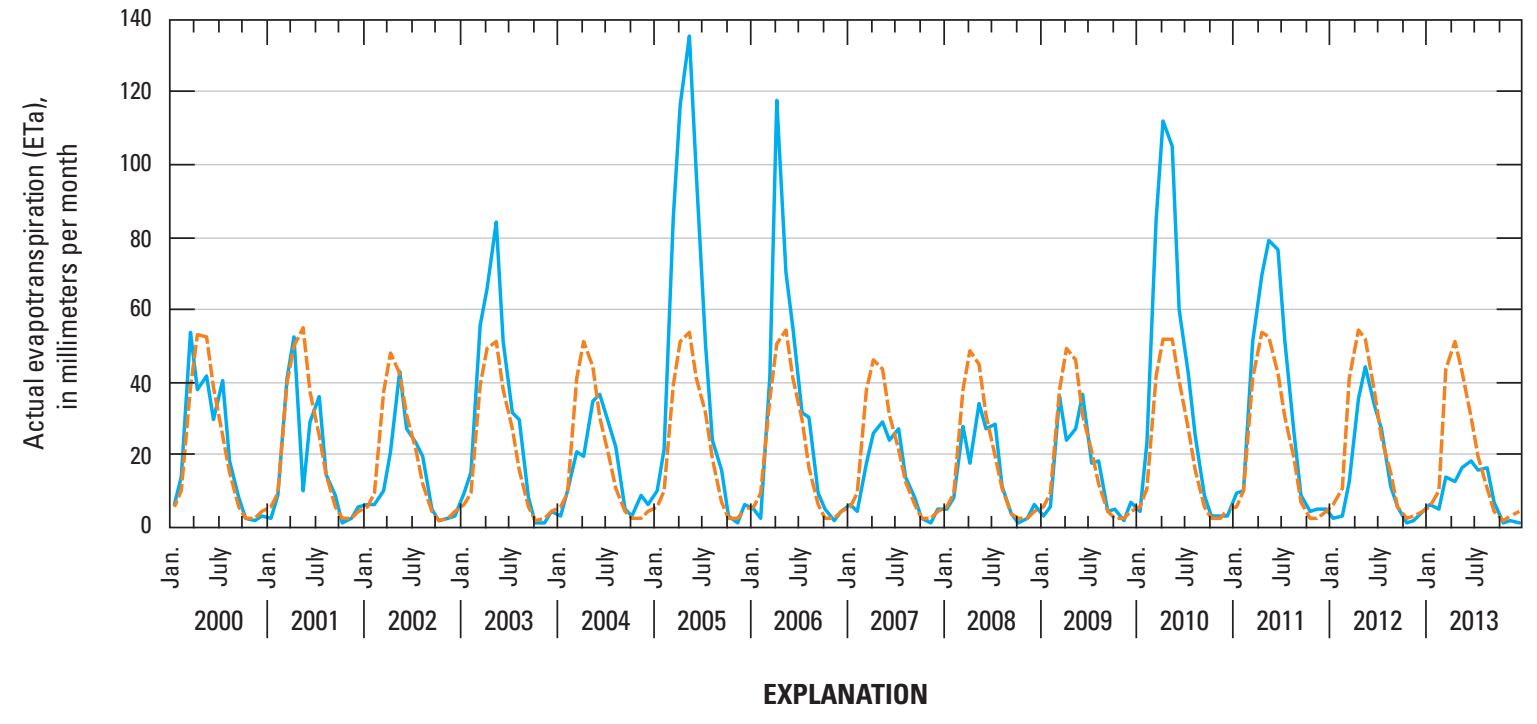

B

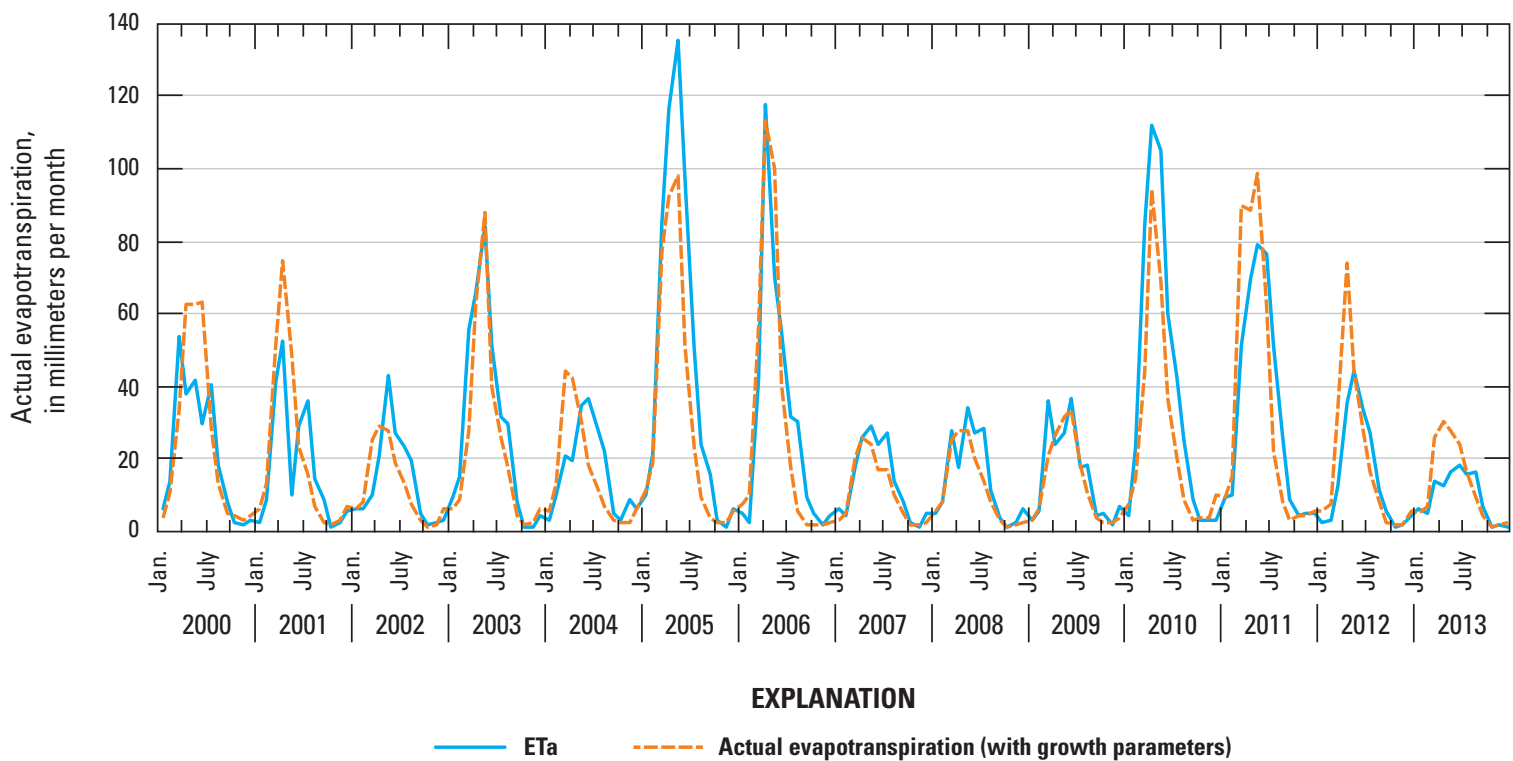

Figure 3.5. Monthly actual evapotranspiration (ETa) for one selected vegetation type (annual grasslands) with $A$, no adjustments to growth parameters and $B$, with growth parameters adjusted to scale with annual variability of precipitation. 


\section{Calibrating the BCMv8 Recharge and Runoff to Local Streamflow}

1. Run BCM_Monthlyv8 for the calibration period using the "fullveg.asc" vegetation file and project basin file.

2. Download local streamflow or full natural flow data (National Water Information System, NWIS, at https://waterdata.usgs.gov/nwis or California Data Exchange Center, CDEC, at https://cdec.water.ca.gov).

3. Set up local calibration spreadsheet (CalBasins.xlsx) for each basin in the basin file.

a. Copy outfile into "outfile" tab and sort by basin number.

b. Copy streamflow data into column E for each calibration tab.

c. Link basin area from outfile to each calibration tab.

d. Link recharge and runoff from outfile to columns $G$ and $\mathrm{H}$, respectively, in the calibration spreadsheet.

e. Adjust time-series graphs to the period of interest.

4. Adjust parameters in orange cells iteratively to minimize the differences in volume from BCMv8-simulated discharge to observed discharge and to optimize the calibration goodness-of-fit statistics ( ${ }^{2}$, NSE, MSE, and variance).

\section{Additional Calibration Considerations}

Other tools that can be adjusted to improve the fits between BCMv8 discharge and observed discharge include soil hydraulic properties, bedrock conductivity (GeolK), and
AET vegetation parameters. The total soil-water storage can be adjusted by using different input maps for porosity or soil-water content at field capacity and wilting point (using SoilPropsv1) to change the amount of water available for AET or the volumes above or below which water may become recharge or runoff. GeolK can be increased if there is too little recharge and the spreadsheet parameters cannot be adjusted enough to match the base flows or recession parts of the hydrograph. It is important to consider that adjusting GeolK for any given geologic type applies the change wherever that geologic type is mapped across the study area. GeolK can be reduced to increase runoff and peak flows. If the AquiferRch scaler is well below 1 when the volume of BCMv 8 discharge is equal to observed discharge, then it is likely that the AET is too low. This often happens in regions with facultative vegetation types that respond very quickly, at less than a monthly time step, to precipitation. Many desert species, for example, grow facultatively when there is rain, but the ETa does not fully represent this phenomenon at its monthly measurement scale. In these cases, $\mathrm{K}_{\mathrm{v}}$ can be raised, as well as UpLimit and UpRate, to increase the AET above the ETa until the AquiferRch scaler is close to 1. If there is not enough recharge and runoff and the AquiferRch scaler is above 1, either the AET is too high and needs adjustment down, or it is possible that the soil storage is too high, and different soil hydraulic properties can be used to decrease soil storage.

Difficulty in calibration can arise as a result of field measurement errors in the streamflow data. More commonly, the basin upstream from the streamgage is regulated by reservoirs or other surface storage that change the timing of flows or is affected by upstream diversions or pumping near channels that reduce the flows, or by return flows from irrigation that increase flows. 


\section{Appendix 4. Available Files for Download}

\section{Server Location - BCMv8 homepage: https://ca.water.usgs.gov/projects/ reg_hydro/basin-characterization- model.html User's Manual Documentation and Files \\ Directory Structure for Downloadable BCMv8 Files}

Software - FORTRAN executable files (*.exe) and control files (*.ctl)

- AddGridsv1, AveGridsv1

- BasinExtractv1

- BCM_Monthlyv8

- ClipGridv1

- Linregv1

- Mklatlonv1

- PET_Actualv1

- Regridv3

- Skyviewv1

- SoilPropsv1

- Solinpv1

- SolPET6

ETa - Actual evapotranspiration grids from Reitz and others (2017) for Oct. 2000-Sep. 2015 that have been spatially downscaled to a 270 -meter resolution for California.

Calibration_tools - CalBasins.xlsx

BCMv8 inputs - California input layers and monthly climate files for 1896-2019 including maximum and minimum temperature; precipitation; potential evapotranspiration; and 30-year average files for precipitation, PET, and solar radiation. Also included is a projection file (*.prj) for use with ArcGIS or other geoprocessing software.

BCMv8_outputs - Output variables from regionally calibrated BCMv8 for California.

\section{Documentation}

\section{User's Manual -}

Flint, L.E., Flint, A.L., and Stern, M.S., 2021, The Basin Characterization Model - A Regional Water Balance Software Package: U.S. Geological Survey Techniques and Methods 6-H1, 85 p., https://doi.org/10.5066/P9PT36UI.

\section{Selected References}

Anderson, E.A., 2006, Snow accumulation and ablation model-SNOW-17: Silver Spring, Md., U.S. National Weather Service.

Bristow, K.L., and Campbell, G.S., 1984, On the relationship between incoming solar radiation and daily maximum and minimum temperature: Agricultural and Forest Meteorology, v. 31, no. 2, p. 159-166, https://doi.org/10.1016/0168-1923(84)90017-0.

Reitz, M., Sanford, W.E., Senay, G.B., and Cazenas, J., 2017, Annual estimates of recharge, quick-flow runoff, and evapotranspiration for the contiguous U.S. using empirical regression equations: Journal of the American Water Resources Association, v. 53, no. 4, p. 961-983, https://doi.org/10.1111/1752-1688.12546.

Saxton, K.E., and Rawls, W.J., 2006, Soil water characteristic estimates by texture and organic matter for hydrologic solutions: Soil Science Society of America Journal, v. 70, no. 5, p. 1569-1578, https://doi.org/10.2136/sssaj2005.0117. 

For more information concerning the research in this report, contact the

Director, California Water Science Center

U.S. Geological Survey

6000 J Street, Placer Hall

Sacramento, California 95819

https://ca.water.usgs.gov

Publishing support provided by the

U.S. Geological Survey Science Publishing Network, Sacramento Publishing Service Center 


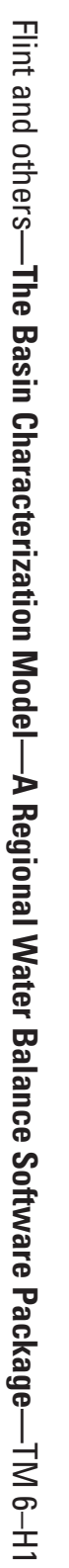

